Universidade de São Paulo

\title{
Museu de Arqueologia e Etnologia
}

"PRÉ-HISTÓRIA DA PROVÍNCIA CÁRSTICA DO ALTO SÃO FRANCISCO, MINAS GERAIS: A INDÚSTRIA LÍTICA DOS CAÇADORES-COLETORES ARCAICOS"
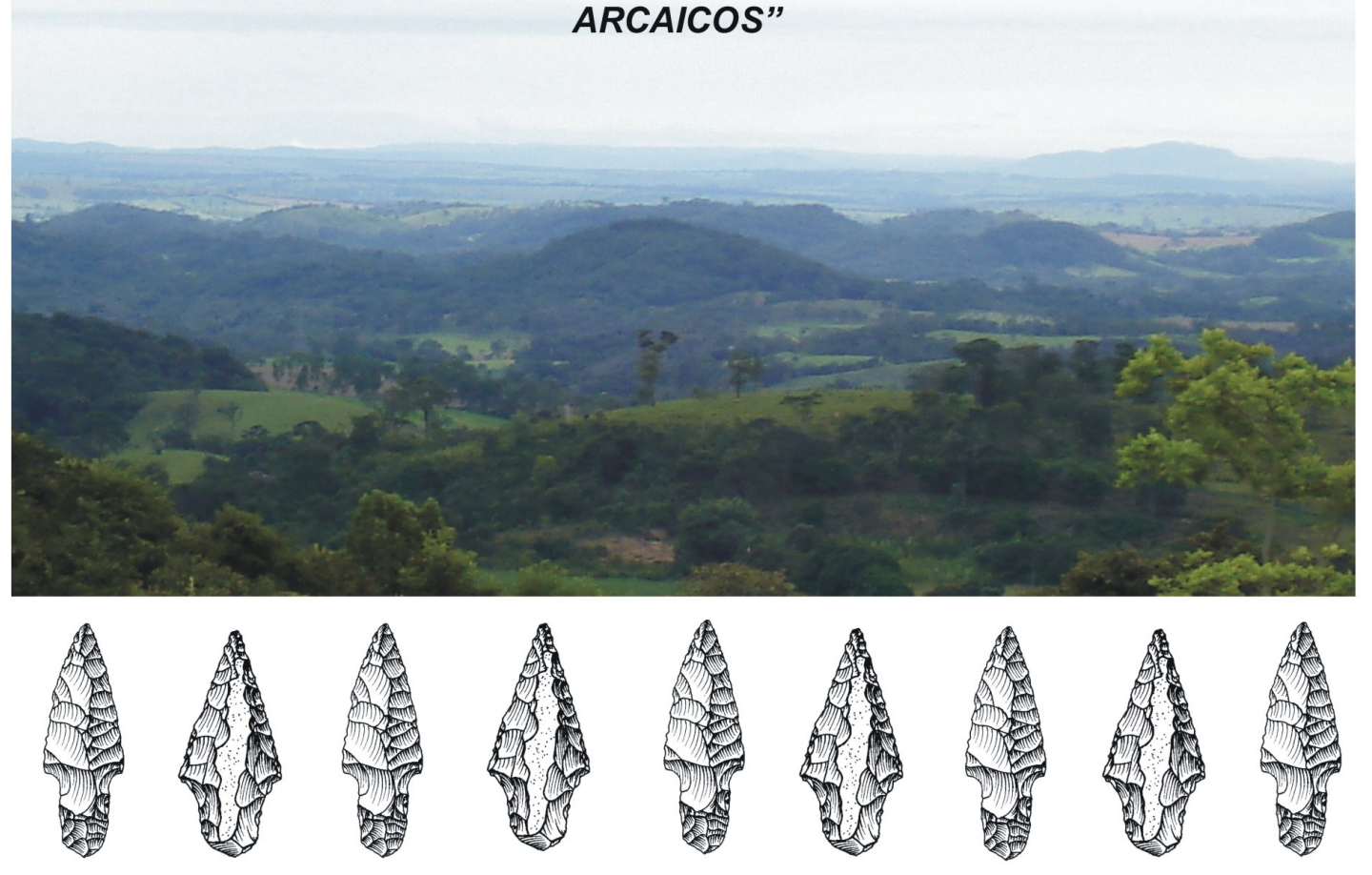

Edward Karel Maurits Koole

Dissertação de Mestrado apresentada como exigência parcial para obtenção do título de Mestre em Arqueologia.

Linha de Pesquisa: Arqueologia Pré-Histórica Orientadora: Profa. Dra. Márcia Angelina Alves 
Aos meus pais, Dies e Tereza 
Em Pains e num raio de umas cinco léguas nas vizinhanças deste arraial o terreno e as serras principalmente são constituídos por rocha calcária, existindo inúmeras caieiras na região. Só este distrito pode fornecer cal para todo território brasileiro.

Os moradores da região, em regra homens rudes e excessivamente supersticiosos, vêem, à noite, e, às vezes, durante a semana santa, ao meio dia $e$ às três horas, seres sobrenaturais, verdadeiros duendes, peregrinando pelas cumiadas das serras, inspecionando se algum homem atrevido violou os seus segredos ou algum larápio saqueou os seus tesouros ocultos nas furnas, que se abrem nas rochas escarpadas. Esses seres sobrenaturais, após suas fastidiosas caminhadas e perigosíssimas ascensões pelas escarpas da serra, vão se refugiar no recôndito das enormes grutas, que constituem sua moradia.

Alacrino Monteiro

(Serviço Geográfico de Minas Gerais, 1939)

Arqueologia é uma corrida longa, uma maratona, e não uma disputa de $100 \mathrm{~m}$ rasos.

Dr. Eduardo Góes Neves 


\section{Agradecimentos}

Agradeço à minha mulher Lílian pelo apoio incondicional;

À minha orientadora Profa. Dra. Márcia Angelina Alves por ter acreditado no meu trabalho;

Aos meus irmãos Carolina, Jan, Matthias, Roeland e Elizabeth e meu sobrinho Julinho pelo carinho;

Ao pessoal da Mata de Pains, São Paulo e Belo Horizonte que diretamente ou indiretamente participaram do projeto: Jeferson Luís, Jáder José, Miguel Villareal, Lucas, Genaro, Diego, Tânia Ribeiro e família, Lucélio Nativo e família, Cadu, Dona Ela, Na e Doglinho, Seu Crispim e família, Dorinho e família, Felipão, Zezé, Virgulino, Silvair e família, Nego do Lourenço e família, Ana Maria e família, Chico, Amauri e Eliana, Lalado e família, Bié e Lucinda, Tico, Seu José Joaquim, Antônio Vieira e família, Sarah, Kazú, Dinho, Alexandre, Márcia, Pitoco, Val, Helena, Danilo, Chumbinho, Mineiro, Danilo, Bartolomucci, Flávio Scalabrini, Eduardo, Marcos e Narciso Haddad, Márcio Castro e família, Dr. Celso, Pedro Teixeira, Rose, Frederico Costa, Paulo Lacale, Luciano e Roberta, João Eduardo Pulier, Robson, Alexandre Pizarro, Marcos Campello e Fernando Frigo;

A Antônio Adauto Leite por ter mostrado sua coleção de pontas de projétil;

Ao Espeleogrupo Pains - EPA por ter compartilhado com os arqueólogos as suas descobertas;

A Leandro Silva, Bernardo Lacale e Vinícius Eduardo pelo trabalho de limpeza e triagem em laboratório;

A Caroline Borges pela análise dos restos faunísticos do sítio Gruta do Marinheiro;

A Cyro José Soares pelas fotos do meio ambiente, sítios e peças arqueológicas;

A Marcos Brito pelos desenhos das pontas de projétil;

Ao. Dr. Paulo de Blasis pela crítica construtiva desde o início;

Ao Dr. Eduardo Góes Neves, pelo apoio fundamental que deu para que a arqueologia na região do alto São Francisco fosse possível;

Ao Dr. Walter Neves e equipe do laboratório de Estudos Evolutivos Humanos (IB/USP) pela curadoria e análise do material ósseo humano da Loca do Suim incluindo a datação de dois esqueletos e também a datação de dois carvões da Escavação 3 - Setor Sul da Gruta do Marinheiro, além das sugestões e críticas.

Ao Museu de Arqueologia e Etnologia da USP por ter me dado a oportunidade de realizar uma pesquisa acadêmica em terras mineiras. Como se sabe, as pesquisas arqueológicas em Minas Gerais foram pioneiras para o Brasil, mas até hoje não existe um mestrado em arqueologia nesse estado; 
À empresa MC Consultoria Ltda., que me permitiu realizar trabalhos de consultoria durante o andamento do mestrado, assim custeando as despesas de campo e laboratório (esse projeto foi realizado sem bolsa de pesquisa);

E finalmente, aos colegas Gilmar e Fernando pelo apoio e amizade ao longo dos anos. 
Resumo - O presente trabalho aborda uma região bem delimitada, circunscrita aos afloramentos calcários do alto curso do rio São Francisco no estado de Minas Gerais $\left(1500 \mathrm{~km}^{2}\right)$. Depois de um período inicial exploratório com levantamentos de superfície intensivos, resultando na descoberta de 120 sítios, duas cavernas, a Loca do Suim e a Gruta do Marinheiro, foram escolhidas para receberem escavações. O objetivo foi comprovar a existência de uma ocupação caçadora-coletora arcaica na região estudada, utilizando como principal elemento descritivo a indústria lítica produzida por esses grupos, envolvendo aspectos como tipologia, tecnologia e cronologia do material. Buscou-se assim colocar em evidência algumas particularidades da região estudada, assim como apontar para eventuais semelhanças com as grandes tradições arqueológicas do período arcaico conhecidas no centro e sul do Brasil.

\begin{abstract}
This project is located in the carstic region $\left(1500 \mathrm{~km}^{2}\right)$ of the upper São Francisco river valley, in the southeastern portion of the Brazilian highlands, $250 \mathrm{~km}$ to the southwest of the well known Lagoa Santa region, State of Minas Gerais. After a period (5 years) of intensive search for sites, discovering more than 120 of them, two caves (Loca do Suim and Gruta do Marinheiro) where excavated. The objective was to prove the existence, also in this area, of archaeological material related to arcaic hunter-gatherers. For being abundant, the lithic industry produced by these pre-historic groups was chosen as main descriptive element. The analysis, based on typological, technological and chronological characteristics of the sample, points out the similarities and differences that exist between this industry and the main lithic archaeological traditions of central and southern Brazil during the arcaic period.
\end{abstract}




\section{Índice}

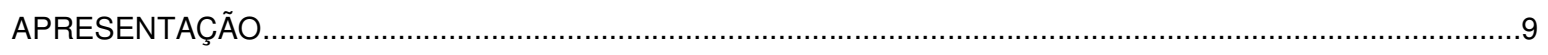

CAPÍTULO 1 - PRESSUPOSTOS TEÓRICOS E PROCEDIMENTOS METODOLÓGICOS...................................12

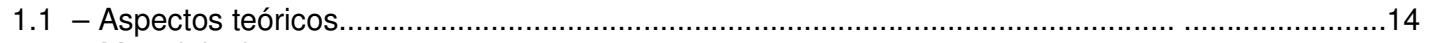

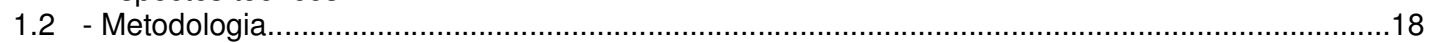

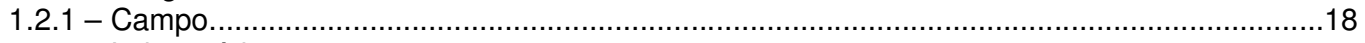

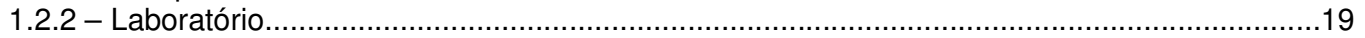

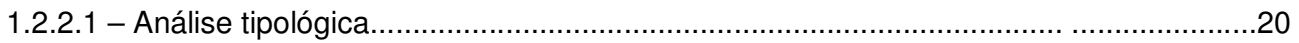

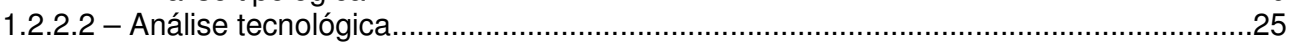

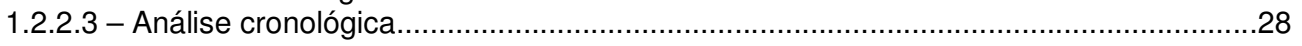

CAPÍTULO 2 - AS PRINCIPAIS INDÚSTRIAS LÍTICAS ARCAICAS DO BRASIL.............................................30

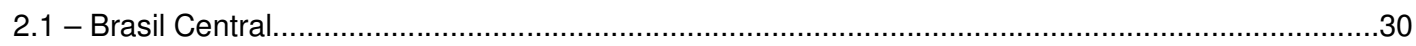

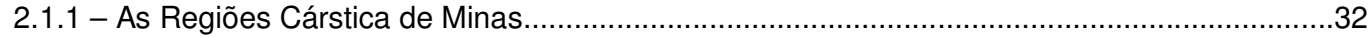

2.1.1.1 - Região de Lagoa Santa..............................................................................

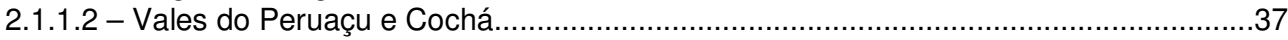

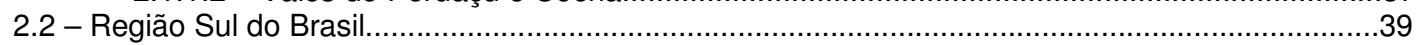

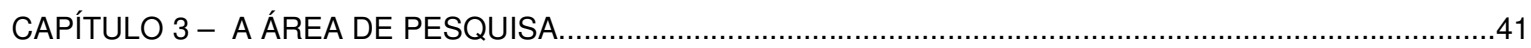

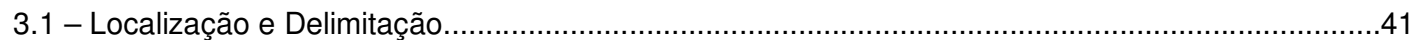

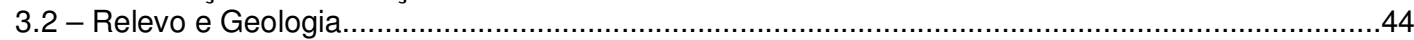

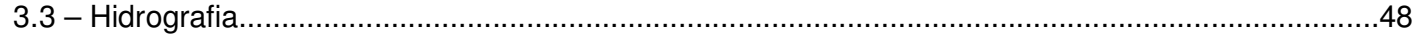

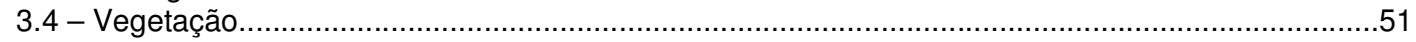

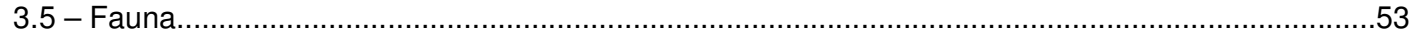

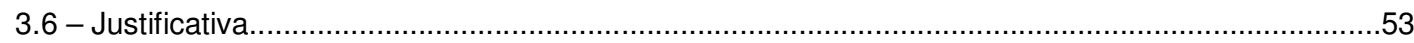

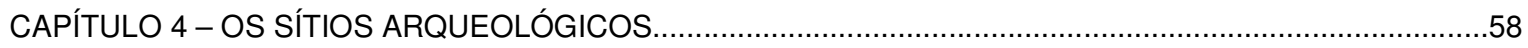

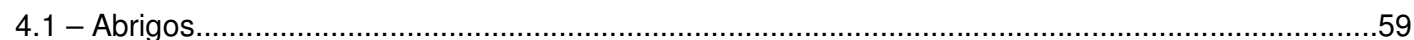

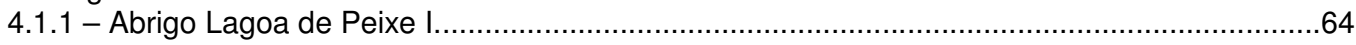

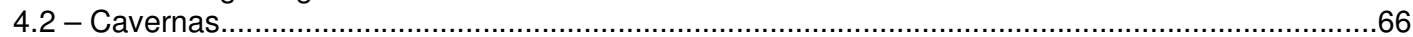

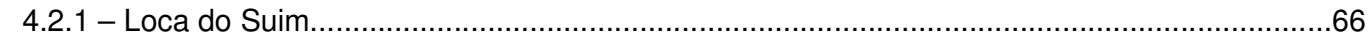

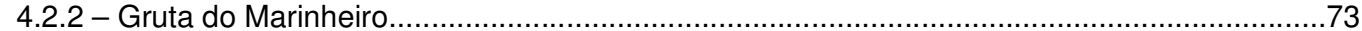

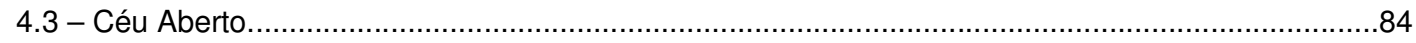

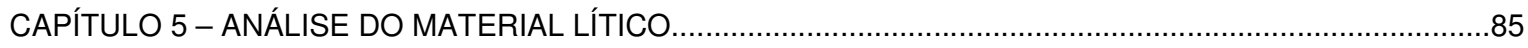

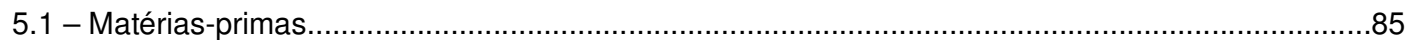

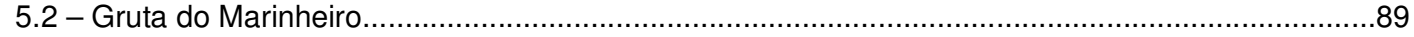

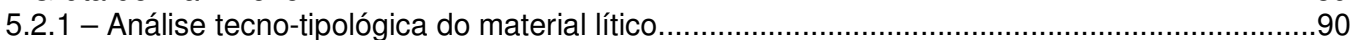

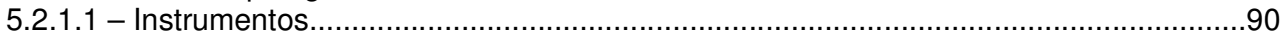

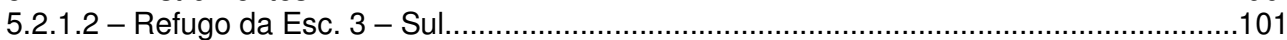

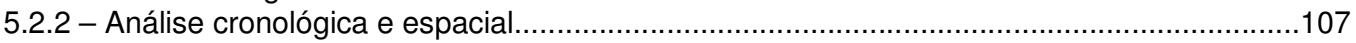

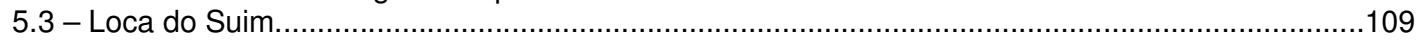

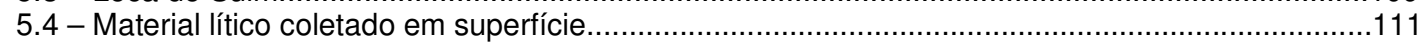

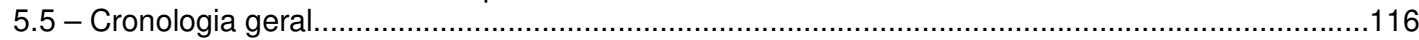

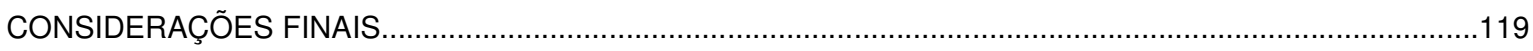

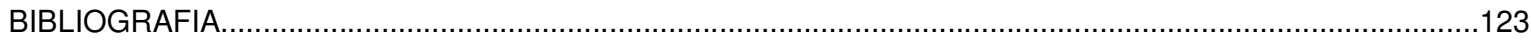

ANEXO - Relatório de Curadoria (Laboratório de Estudos Evolutivos Humanos - IB/USP)...........................127 


\section{Relação das figuras: mapas, fotos, gráficos, desenhos, tabelas, plantas e perfils estratigráficos ${ }^{1}$}

Página 11 - Mapa de Minas Gerais com localização da Província Cárstica do Alto São Francisco (Edward Koole/ Gilmar Henriques; 2006).

14 - Foto com vista parcial do sítio Loca do Suim durante as escavações (Cyro Soares; 2005).

21 - Quadro com classificação tipológica adotada neste trabalho (Edward Koole; 2007) .

23 - Foto de raspador lateral proveniente do Abrigo Lagoa do Retiro (Cyro Soares; 2005).

30 - Foto (Cyro Soares; 2007) e desenho de instrumento plano-convexo do triângulo mineiro (Edward Koole; 2007).

31 - Foto de quatro plano-convexos do triângulo mineiro (Cyro Soares; 2005).

41 - Foto do Rio São Francisco recortando a Província Cárstica do Alto São Francisco (Cyro Soares; 2004).

42 - Foto de afloramentos calcários no limite dos municípios de Arcos e Pains (Cyro Soares; 2004).

43 - Mapa antigo cobrindo o alto São Francisco e médio Rio Grande (localizado por Eduardo Haddad no Arquivo Público Mineiro).

44 - Foto com vista parcial da Serra da Pimenta (Edward Koole; 2006).

46 - Foto da entrada da Gruta do Isaías, município de Pains (Cyro Soares; 2004).

48 - Perfil geológico da Serra da Canastra até Arcos.

49 - Foto da Lagoa de Peixe em época de cheia (Edward Koole; 2003).

50 - Foto parcial do Planalto de Dolinas (Cyro Soares; 2006).

52 - Fotos da vegetação encontrada no carste (Cyro Soares; 2005.

55 - Foto-montagem com o maciço Quenta-Sol, localizado na porção norte da Província (Edward Koole; 2005)

56 - Tabela com relação das datações radiocarbônicas obtidas para a ocupação dos horticultores-ceramistas na região.

57 - Fotos de abrigo com pingueira e vestígios encontrados em superfície (Edward Koole; 2006).

59 - Tabela com a relação dos 13 sítios pesquisados.

60 - Foto-montagem com o Abrigo da Estiva (Edward Koole; 2002).

60 - Mapa com a localização dos sítios e ocorrências pesquisados no presente estudo (Edward Koole; 2006 - sobre base de Alexandre Pizarro)

62 - Planta-baixa do Abrigo da Mureta (Edward Koole/ Jéferson Luís; 2003).

63 - Planta-baixa do Abrigo Lagoa do Retiro (Edward Koole/ Jéferson Luís; 2003).

64 - Fotos da coleta de superfície realizada no Abrigo Lagoa de Peixe I (Gilmar Henriques; 1999).

65 - Planta-baixa do Abrigo Lagoa de Peixe I (Andrei Isnardis; 1999, Edward Koole; 2006).

67 - Fotos Morro da Menina, onde se encontra a Loca do Suim (Edward Koole; 2005 e 2006).

68 - Planta-baixa da entrada da Loca do Suim (Gilmar Henriques; 2005).

70 - Perfil estratigráfico da parede norte, na Área 1, Loca do Suim (Edward Koole; 2005).

71 - Planta-baixa com os três sepultamentos da Loca do Suim (Edward Koole; 2006).

72 - Fotos dos Sepultamento I (Edward Koole e Gilmar Henriques; 2005).

74 - Tabela das áreas escavadas e das profundidades atingidas por setor na Gruta do Marinheiro.

75 - Planta-baixa (parcial) e foto com vista geral da Gruta do Marinheiro (Eduardo Haddad e Edward Koole; 2006).

76 - Perfil e foto da parede leste, na Esc. 1, da Gruta do Marinheiro (Tiago e Edward Koole; 2006).

78 - Fotos Esc. 1, camada superficial, Gruta do Marinheiro (Edward Koole; 2006).

79 - Fotos Esc. 2, Gruta do Marinheiro (Edward Koole; 2006).

81 - Fotos Esc. 3, decapagem superficial, Gruta do Marinheiro (Edward Koole; 2006).

82 - Planta-baixa da decapagem superficial e perfil estratigráfico, na Esc. 3, Gruta do Marinheiro (Edward Koole; 2006).

83 - Fotos Esc. 3, escavação por nível arbitrário, Gruta do Marinheiro (Edward Koole; 2006).

84 - Gráfico com quantidade de peças por nível do setor Esc.3 - Norte (Edward Koole; 2007).

84 - Tabela com relação das ocorrências e tipos de vestígios encontrados nelas.

86 - Fotos de dois pequenos plano-convexos encontrados na Província (Cyro Soares; 2005).

87 - Fotos de fontes de matérias-primas (chert) na área do carste (Edward Koole; 1999-2003).

89 - Gráfico com percentagem do material lítico por setor, Gruta do Marinheiro.

91 - Desenhos de peças unifaciais, Gruta do Marinheiro (Edward Koole; 2007).

92 - Gráficos com distribuição vertical dos instrumentos unifaciais por matéria-prima e tamanho, Gruta do Marinheiro (Edward Koole; 2007).

92 - Desenho de instrumentos com gumes bifaciais, Gruta do Marinheiro (Edward koole; 2007).

93 - Gráficos com a distribuição vertical dos instrumentos com gumes bifaciais por matéria-prima e tamanho, Gruta do Marinheiro (Edward Koole; 2007).

93 - Tabela com a relação das pré-formas, Gruta do Marinheiro (Edward Koole; 2007)

${ }^{1}$ As figuras não foram numeradas individualmente mas estão indicadas pela página em que se encontram. 
94 - Desenho esquemático dos três tipos de pré-formas sobre lasca encontradas na Gruta do Marinheiro (Edward Koole; 2007).

95 - Gráfico com relação das pontas de projétil inteiras e fragmentadas por matéria-prima, Gruta do Marinheiro (Edward Koole; 2007).

95 - Gráficos com distribuição vertical das pontas segundo o tipo de matéria-prima, o grupo de tamanho e o tipo de pedúnculo, Gruta do Marinheiro (Edward Koole; 2007).

96 - Fotos (Cyro Soares; 2006) e desenhos de pontas de projétil (Marcos Brito; 2007).

97 - Desenhos de pontas de projétil, Gruta do Marinheiro (Marcos Brito; 2007)..

98 - Fotos de pontas de projétil, Gruta do Marinheiro (Cyro Soares; 2006).

99/100 - Tabela com relação das pontas inteiras encontradas na Província (Edward Koole; 2006).

100/101 - Tabela com relação das pontas fragmentadas, Gruta do Marinheiro (Edward Koole; 2006).

101 - Gráficos com relação dos tipos de instrumentos por nível, na Esc. 3 - Sul, Gruta do Marinheiro (Edward Koole; 2007).

102 - Gráficos com distribuição do refugo por matéria-prima e nível arbitrário, na Esc. 3 - Sul, Gruta do Marinheiro (Edward Koole; 2007).

103 - Gráficos com a distribuição do refugo por tipo e nível, na Esc. 3 - Sul, Gruta do Marinheiro (Edward Koole; 2007). .

104 - Gráficos com distribuição das lascas inteiras por grupo de tamanho e nível, na Esc. 3 - Sul, Gruta do Marinheiro (Edward Koole; 2007). .

105 - Gráficos com tipos de refugo por matéria-prima e nível, na Esc. 3 - Sul, Gruta do Marinheiro (Edward Koole; 2007). .

106 - Gráficos com as lascas inteiras por matéria-prima e nível, na Esc. 3 - Sul, Gruta do Marinheiro (Edward Koole; 2007). .

107 - Perfil e cronologia do pacote arqueológico, na Esc. 3 - Sul, Gruta do Marinheiro (Edward Koole; 2007).

108 - Gráficos com relação percentual das matérias-primas, tipos de instrumentos e refugo, e as lascas inteiras por nível, na Esc. 3 - Sul, Gruta do Marinheiro (Edward Koole; 2007). .

110 - Relação das lascas inteiras por matéria-prima e nível, na Área 1, Loca do Suim (Edward Koole; 2007). .

112 - Quantidade de lascas inteiras por grupo de tamanho e matéria-prima do Abrigo Lagoa de Peixe I (Edward Koole; 2007).

114 - Prancha com desenhos dos vestígios do Abrigo Lagoa de Peixe I (Gilmar Henriques; 2002).

115 - Desenhos de dois raspadores laterais encontrados em superfície, fora das áreas de pingueiras (Edward Koole; 2007). .

116 - Desenho de ponta de projétil encontrada em superfície, em ocorrência isolada na região do Barreado (Marcos Brito; 2007).

117 - Tabela com faixas de ocupação pré-histórica na região (Edward Koole; 2007). .

120 - Fotos de pontas de projétil provenientes da coleção particular de Antônio Adauto Leite (Cyro Soares; 2005).

121 - Desenho de ponta de projétil encontrada em sítio na beiro do Lago de Furnas, município de Carmo do Rio Claro (Marcos Brito; 2007).

122 - Mapa da porção sul e sudeste do Brasil com a distribuição territorial da tradição Umbu que, segundo a presente pesquisa, poderia se estender (ainda a confirmar) até o centro-oeste mineiro (Edward Koole; 2007). 


\section{APRESENTAÇÃO}

Esta dissertação apresenta os resultados obtidos no projeto de mestrado intitulado "PréHistória da Província Cárstica do Alto São Francisco, Minas Gerais: a Indústria Lítica dos Caçadores-Coletores Arcaicos", desenvolvido de 2004 a 2007 no Museu de Arqueologia e Etnologia/MAE da Universidade de São Paulo/USP.

O trabalho aborda uma região bem delimitada, circunscrita aos afloramentos calcários do alto curso do rio São Francisco no estado de Minas Gerais. O objetivo foi comprovar a existência de uma ocupação caçadora-coletora arcaica na região em questão, utilizando como principal elemento descritivo a indústria lítica produzida por esses grupos, envolvendo aspectos como tipologia, tecnologia e cronologia do material. Buscou-se assim colocar em evidência algumas particularidades da região estudada, assim como apontar para eventuais semelhanças com as grandes tradições arqueológicas do período arcaico identificadas no centro e sul do Brasil.

A associação com caçadores-coletores na Província se deu inicialmente, antes das intervenções, a partir de aspectos tecno-tipológicos do material lítico encontrado em locais erodidos na entrada de abrigos e cavernas; depois, durante os trabalhos de escavação, pela ausência de cerâmica nos estratos arqueológicos enterrados e finalmente, graças a quatro datações absolutas obtidas nos dois sítios escavados no âmbito deste projeto.

Uma amostra de 23904 peças líticas foi levantada a partir de 13 sítios arqueológicos e 4 ocorrências isoladas. A maior parte é originária do sítio Gruta do Marinheiro (96,8\% das peças), completada por aquelas obtidas nas escavações da Loca do Suim $(2,6 \%)$ e na coleta de superfície no Abrigo Lagoa de Peixe I (0,6\%). Os conjuntos líticos enterrados foram coletados em escavações por níveis arbitrários, associados a sedimento antrópico com carvões esparsos, restos faunísticos e/ou enterramentos humanos. Nos 10 sítios restantes e nas 4 ocorrências foram realizadas coletas seletivas de algumas poucas peças significativas (suportes retocados) encontradas em superfície (menos de $0,1 \%$ da amostra).

Apesar da escolha de realizar um estudo das indústrias líticas, sabe-se que esse tipo de vestígio constitui apenas um dos elementos materiais associado à ocupação caçadora-coletora da região. Outros tipos de vestígios como restos faunísticos, arte rupestre, carvões e ossos humanos, são igualmente importantes para a construção de um quadro do passado préhistórico. Nesse sentido, os restos faunísticos da Gruta do Marinheiro e os ossos humanos da Loca do Suim foram aproveitados por pesquisadores da USP para análises especializadas. 
Além disso, duas amostras de carvões e duas de osso humano foram enviadas, por iniciativa do Laboratório de Estudos Evolutivos Humanos (IB/USP), para laboratório de datação radiocarbônica $(\mathrm{C} 14)$.

O corpo da presente dissertação comporta cinco capítulos, a saber:

- Cap. 1: Pressupostos Teóricos e Procedimentos Metodológicos.

O capítulo apresenta a posição teórica adotada neste trabalho e aborda aspectos gerais ligados à caracterização de grupos caçadores-coletores do período arcaico. Em seguida, descreve os procedimentos metodológicos utilizados em campo, para a coleta da amostra, e em laboratório, para a análise e processamento dos dados.

- Cap. 2: As Principais Indústrias Líticas Arcaicas do Brasil

Trata da problemática arqueológica relacionada às indústrias líticas de grupos caçadores-coletores encontrados no centro e no sul do Brasil, que servem como referências comparativas para a Província Cárstica do Alto São Francisco.

- Cap. 3: Área de Pesquisa.

Delimitação da área em foco e caracterização a partir de aspectos físicos e naturais (geologia, relevo, hidrografia, vegetação e fauna). Apresenta também a contextualização da arqueologia regional.

- Cap. 4: Os Sítios Arqueológicos.

Capítulo que descreve os sítios envolvidos na pesquisa e as respectivas atividades desenvolvidas em cada um, com destaque para os três que forneceram a maior parte da amostra lítica: Gruta do Marinheiro, Loca do Suim e Abrigo Lagoa de Peixe I.

- Cap. 5: A Indústria Lítica.

A análise começa com uma descrição das matérias-primas encontradas nos sítios; em seguida foi, dividida em três partes segundo o contexto de deposição do material lítico, ou seja, proveniente das escavações na Gruta do Marinheiro, na Loca do Suim ou coletado em superfície, como no Abrigo Lagoa de Peixe I. 


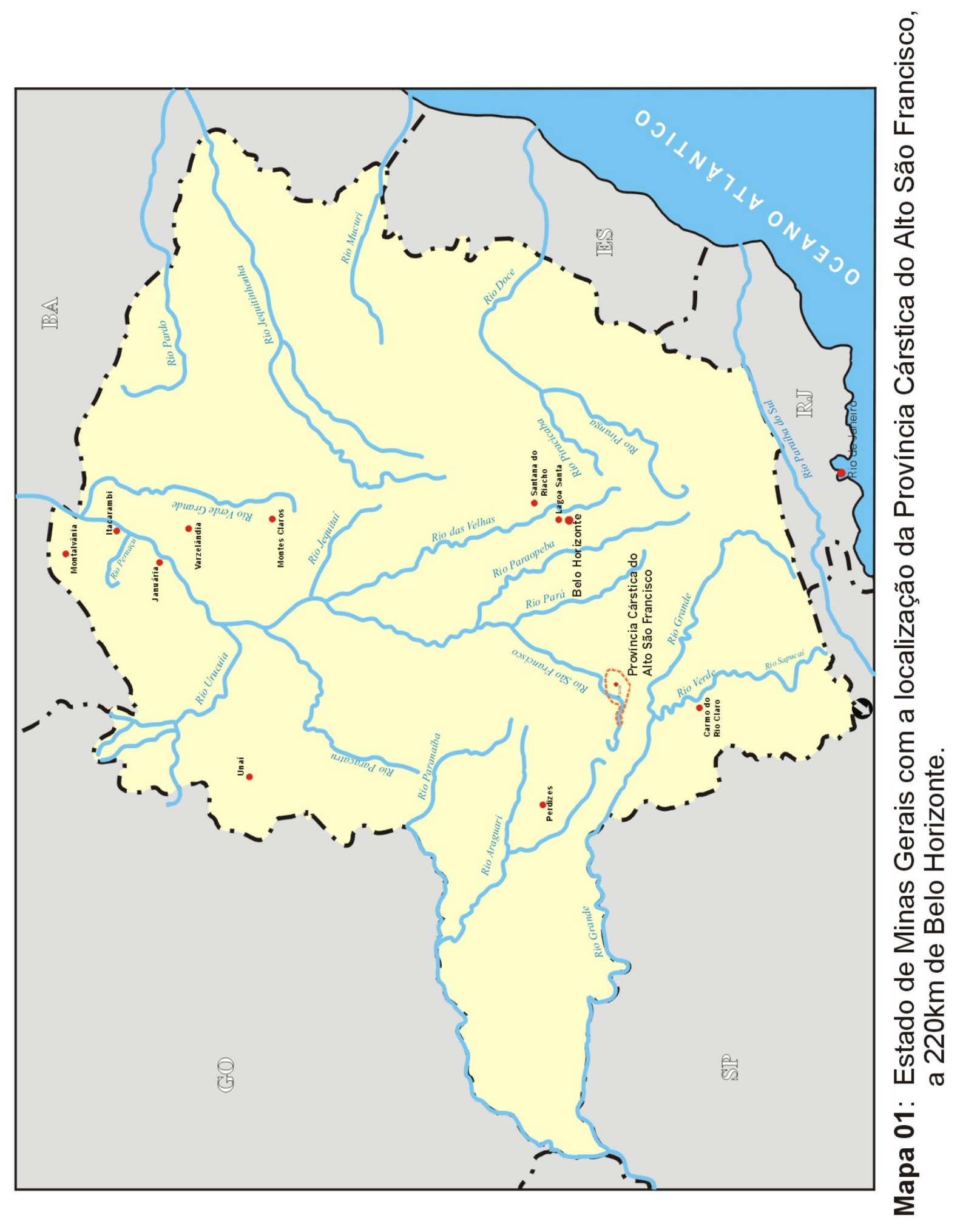




\section{CAPÍTULO 1 - PRESSUPOSTOS TEÓRICOS E PROCEDIMENTOSMETODOLÓGICOS}

A posição teórica adotada pelo arqueólogo, em geral determinada pela época e pelo país em que estudou, vai se projetar, consciente- ou inconscientemente, sobre a execução e nos principais objetivos da sua investigação. No que concerne o Brasil, a formação de profissionais se intensificou no início dos anos 1960 a partir de cursos e práticas de campo coordenados por arqueólogos norte-americanos ${ }^{2}$ e franceses $^{3}$. A perspectiva históricoculturalista $^{4}$, difundida por ambas escolas no país, marcou fortemente a arqueologia brasileira durante as décadas seguintes e não deixa de estar presente também nesta dissertação de mestrado.

Los que siguen este enfoque [histórico-cultural] se proponen como meta la elucidación y la perfecta resolución de las secuencias regionales basadas en uma minuciosa observación estratigráfica. La comparación y análisis del material de artefactos se funda en el reconocimiento de patrones de similitudes y diferencias en las formas de los artefactos y en la composición de conjunto. [...] Han sido considerables los logros por documentar culturas del pasado de la humanidad que difieran radicalmente de cualquier outra que pueda encontrar-se en los archivos históricos o en el mundo actual (GAMBLE, 1990:21).

Apesar das duas escolas introduzirem no Brasil, essencialmente, uma mesma orientação teórica, a metodologia adotada e, consequentemente, os resultados obtidos por seus representantes no país, envolvendo tanto arqueólogos brasileiros quanto os próprios arqueólogos estrangeiros, foram diferenciados. A escola norte-americana, influenciada por estudos de padrão de assentamento, teve uma preocupação com amplas partes do território nacional, com ênfase nos povos horticultores-ceramistas (com exceção das pesquisas no Rio Grande do Sul e na região de Lagoa Santa). A necessidade de cobrir uma área relativamente grande limitou o tempo médio disponível por sítio pesquisado, o que influenciou diretamente na maneira de escavar, caracterizada pela abertura de áreas reduzidas (sondagens) e utilização de níveis artificiais ${ }^{5}$. A escola francesa, por outro lado, fixou seus esforços em alguns nichos com alto potencial arqueológico, com ênfase (mas não exclusivamente) nos pré-ceramistas.

\footnotetext{
${ }^{2}$ Betty Meggers e Clifford Evans; Wesley Hurt; Alan Bryan.

3 Joseph Emperaire e Annette Laming-Emperaire.

4 A abordagem histórico-culturalista foi hegemônica no Brasil até os anos 1980, quando surgiram trabalhos acadêmicos com preocupações sistêmicas, voltadas mais para a compreensão do funcionamento (em determinada época) das comunidades pré-históricas do que para a caracterização das seqüências culturais no tempo e espaço. A tendência se iniciou nos países anglo-saxões algumas décadas antes com a crítica de que haveria uma proliferação de tipologias sem aparente preocupação com comportamentos humanos concretos.

${ }^{5}$ Os níveis artificiais são mais fáceis de escavar que os naturais e podem ser utilizados em qualquer contexto, seja em abrigo ou a céu aberto.
} 
Trabalhando em áreas mais restritas, eles investiram tempo e esforço em alguns poucos sítios em cada região pesquisada. A razão prática pela demora nos sítios, frequentemente vários anos seguidos, estava no tamanho das escavações (amplas) e na maneira em que eram realizados os registros, com alto grau de detalhamento ${ }^{6}$.

Pode-se dizer que o presente trabalho contempla também um tipo de "nicho com alto potencial arqueológico". Trata-se de uma região cárstica situada no alto vale do rio São Francisco, conhecida como "Província Cárstica do Alto São Francisco" (ou simplesmente a "Província"). Ela representa uma área bastante extensa, com cerca de $1500 \mathrm{~km}^{2}$ e é de alta relevância arqueológica por causa dos sedimentos antrópicos preservados em centenas de cavernas e abrigos, muitos dos quais ainda em ótimo estado de conservação se comparado com aqueles da região de Lagoa Santa, por exemplo. A região, no entanto, nunca recebeu (até pouco tempo atrás) a devida atenção por parte das instituições acadêmicas, no que tange a arqueologia. Os vestígios associados à ocupação de horticultores-ceramistas na região foram recentemente tratados em um projeto de mestrado defendido no Museu de Arqueologia e Etnologia da Universidade de São Paulo (HENRIQUES, 2006) ${ }^{7}$.

Escolheu-se inicialmente realizar escavações em três sítios abrigados, reduzido, ao longo dos trabalhos, para dois. As intervenções, todas por nível arbitrário ${ }^{8}$, foram relativamente intensas com aberturas de unidades $\left(1 \mathrm{~m}^{2}\right)$ e trincheiras (a maior com $2 \mathrm{~m}$ de largura por $5 \mathrm{~m}$ comprimento); cerca de 40 dias de trabalho foi dispensado em cada sítio escavado ${ }^{9} \mathrm{com}$, no total, $22 \mathrm{~m}^{2}$ abertos ( $6 \mathrm{~m}^{2}$ na Loca do Suim $^{10}$ e $16 \mathrm{~m}^{2}$ na Gruta do Marinheiro). O grau de detalhamento do registro variou dependendo da ausência ou presença de estruturas. Não foi realizado um registro da posição exata de todo refugo lítico, que apenas foi agrupado por nível arbitrário ${ }^{11}$.

O presente trabalho não teve a pretensão de obter uma amostra lítica suficientemente representativa para a região como um todo, o que a caracterizaria como um estudo de arqueologia regional. Não se trata disso, entretanto, foi descoberta uma indústria rica (densa e relativamente variada) que poderá jogar alguma luz sobre aspectos da tecnologia de lascamento utilizada pelos caçadores-coletores que percorriam a região durante $o$ arcaico.

\footnotetext{
${ }_{7}^{6}$ Essa postura revela implicitamente a crença no alto grau de preservação dos sítios.

${ }^{7}$ Um resumo dos resultados desse projeto pode ser encontrado no Capítulo 3.

${ }^{8}$ Com exceção da "decapagem" experimental que foi realizada no início da Escavação 3 na Gruta do Marinheiro.

${ }^{9} \mathrm{O}$ tamanho da equipe variou de duas a quinze pessoas durante as escavações.

${ }^{10} \mathrm{Na}$ verdade trata-se de um arredondamento: a área exata escavada na Área 1 é de $5,84 \mathrm{~m}^{2}$. A ampliação da escavação na Área 1 da Loca do Suim, para caberem todos sepultamentos, aconteceu por três vezes.

${ }^{11}$ Não se dispunha do tempo necessário para tal empreendimento do qual, frequentemente, obtém-se relativamente pouca informação relevante para o enorme esforço, tanto em campo quanto em laboratório, que exige.
} 


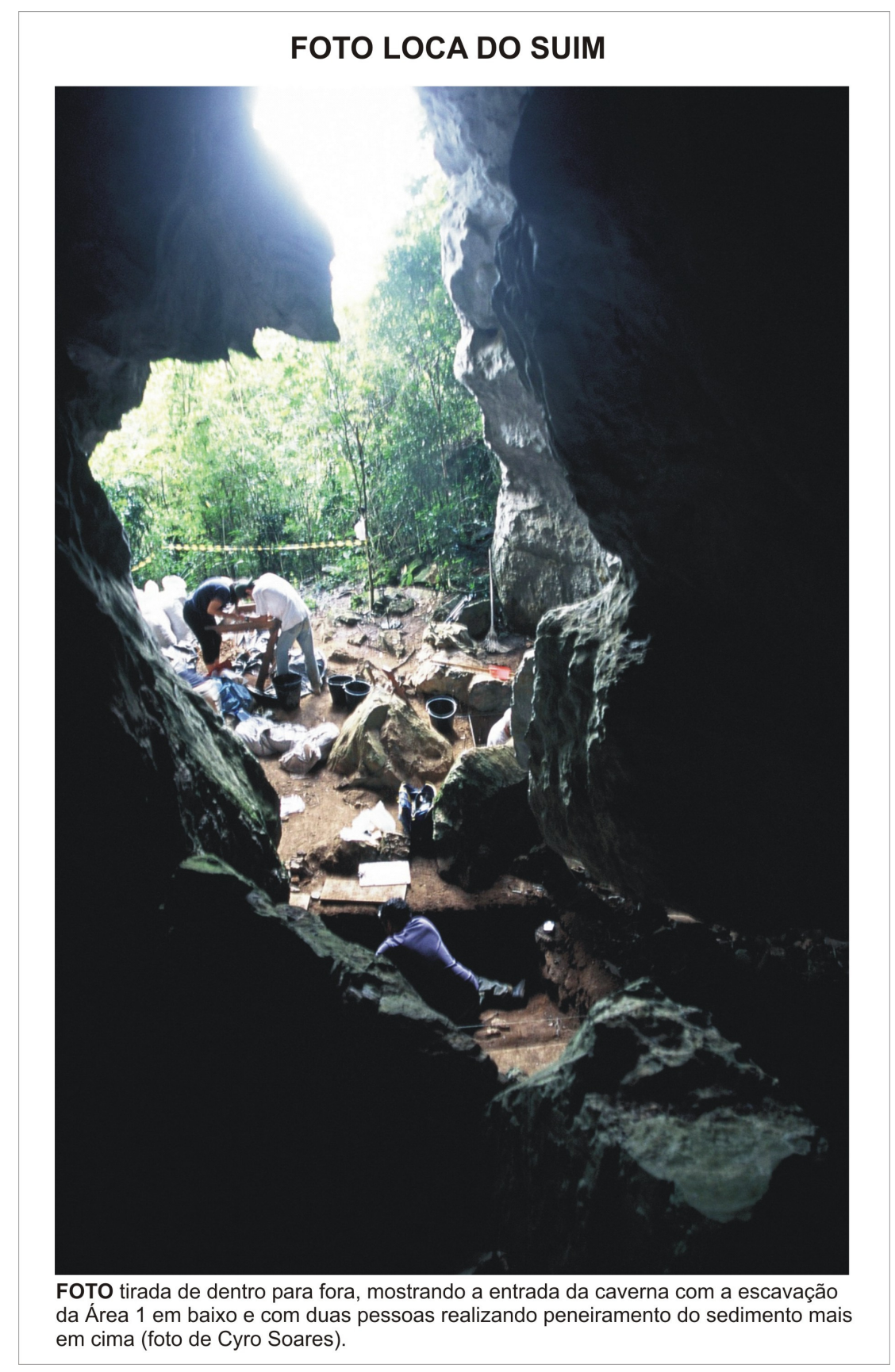

\section{1 - Aspectos teóricos}

Acredita-se que qualquer cultura depende de um conjunto de conhecimentos e comportamentos que são repassados através do ensino e da aprendizagem e que podem ser modificados ou adaptados a cada nova geração. Abrange, além de elementos que não foram materializados, um conjunto de objetos materiais, produzidos voluntariamente ou não. Esses são geralmente as únicas informações concretas que restaram dos povos pré-históricos, 
especialmente para os períodos mais remotos para os quais não existem fontes proto-históricas ou etnográficas.

O presente estudo se apoiou em uma análise essencialmente empírica ${ }^{12}$ a partir da descrição das características formais (variabilidade artefatual), espaciais (distribuição horizontal) e temporais (distribuição vertical) de uma amostra lítica proveniente de 13 sítios arqueológicos, dois dos quais tiveram escavações. A variabilidade artefatual foi descrita a partir de uma análise tecno-tipológica do material lítico; a análise espacial foi realizada a partir da descrição dos diferentes vestígios e estruturas identificados em superfície e nas unidades e áreas maiores escavadas; e finalmente, a análise da distribuição vertical se apoiou nos níveis arbitrários escavados, perfils estratigráficos e nas datações radiocarbônicas obtidas.

Pode-se dizer que as variações observadas nos vestígios materiais são um dos principais parâmetros utilizados para diferenciar culturas arqueológicas. A tipologia, o estudo dessas variações, acontece a partir de estabelecimento de tipos de artefatos, sejam eles refugo ou instrumentos propriamente ditos, com atributos característicos, envolvendo aspectos ligados à morfologia e funcionalidade, tecnologia de fabricação e matérias-primas utilizadas.

A análise tipológica envolve, portanto, um juízo sobre o que representam os elementos verdadeiramente significativos ou singulares de uma determinada cultura (PROUS, 1992). Em relação à indústria lítica do arcaico brasileiro isso aconteceu principalmente através da caracterização de um ou mais instrumentos típicos (fósseis-guia), apesar do refugo de fabricação sempre representar a maior parte da amostra de um sítio lítico minimamente constituído. Um dos resultados da abordagem histórico-culturalista no Brasil foi o estabelecimento de duas grandes tradições arcaicas, baseadas cada uma em peças retocadas caraterísticas e ocupando determinada faixa temporal e tipo de ambiente natural: essas culturas são as tradições Itaparica e Umbu. O pertencimento de uma terceira tradição, a Humaitá, a grupos caçadores-coletores foi recentemente contestado pela pesquisadora Adriana Dias em sua tese de doutorado.

Os dados arqueológicos e datações produzidas nos últimos 40 anos para a região nordeste do Estado [de Rio Grande do Sul] e os resultados das pesquisas de campo desenvolvidas no Alto Vale do Rio dos Sinos, reforçam esta hipótese, sugerindo que um único grupo caçador coletor, associado à Tradição Umbu, ocupou esta área, pertencendo os sítios líticos identificados como associados à Tradição Humaitá aos sistemas de assentamento de horticultores (DIAS, 2003:290).

\footnotetext{
${ }^{12} \mathrm{~A}$ indução predomina sobre a dedução na abordagem empírica, o que implica em uma visão dominada pela descrição e interpretação dos materiais e estruturas encontrados nos sítios.
} 
Por isso, e pelo fato dos vestígios dessa tradição (Humaitá) não parecerem nada com o que foi encontrado na Província, essa não foi incluída no presente estudo como elemento comparativo.

Apesar das análises aqui se basearem, como foi mencionado acima, no que os sítios puderam oferecer (em uma perspectiva empírica), as evidências não foram interpretadas em um completo vazio teórico. Idéias preconcebidas sobre o significado das informações arqueológicas e sobre aspectos gerais das sociedades caçadoras-coletoras como subsistência, territorialidade, divisão do trabalho, etc., também foram levantadas.

No que concerne o significado das evidências foi adotado a perspectiva históricoculturalista, na qual as culturas materiais podem ter uma conotação étnica, conhecido como estilo, onde a semelhança estilística denota proximidade cultural (DIAS, 2003:42).

\begin{abstract}
A interpretação das semelhanças e diferenças nos padrões morfológicos dos artefatos costuma ser feita em termos de unidades histórico-culturais, com conotações étnicas, e as mudanças ao longo do tempo nestes padrões são explicadas, principalmente, em termos de processos de difusão e migração. De acordo com esta perspectiva teórica, o estilo pode ser lido na forma dos artefatos, sendo as variações morfológicas interpretadas como resultantes da ação de grupos étnicos diferentes (DIAS, 2003:42).
\end{abstract}

O corte temporal adotado foi o período conhecido como o arcaico, abrangendo o intervalo do início do holoceno até o aparecimento dos horticultores-ceramistas e que teve uma duração de cerca de 9 mil anos, passando pelo arcaico antigo e médio até o recente. Trata-se do período anterior à utilização da cerâmica que pode ser reconhecido, principalmente em sítios abrigados quando com pisos em condições de deposição estáveis, nos extratos arqueológicos localizados abaixo de depósitos, evidentemente mais superficiais, com cerâmica.

Para o período anterior ao arcaico, ou seja, os últimos milênios do pleistoceno, as evidências são ainda escassas e muito dispersas no território e, portanto, pouco claras. Entretanto, acredita-se que, por causa dessa "quase ausência" de sítios, havia uma população relativamente escassa e dispersa na paisagem. Especula-se que a ocupação então relacionava-se à fase de desbravamento do território brasileiro, que pode ter durado milhares de anos e que talvez pode ser caracterizado pela gradativa expansão populacional sustentada pelos recursos encontrados em novos territórios. Por causa do grande aumento no número de sítios arqueológicos para o início do holoceno, esse movimento desbravador, que não sabe-se quanto tempo durou, parece ter chegado a um fim $^{13}$, o que pode também ter significado o fim de um estilo de vida e o surgimento de outro.

\footnotetext{
${ }^{13}$ A ocupação de todos os espaços, além da expansão dos grupos já existentes, pode ter sido acelerada por ondas de imigração.
} 
Pelas evidências arqueológicas conhecidas acredita-se que praticamente todos espaços do continente estavam sendo explorados a partir do início do holoceno ${ }^{14}$, ou seja, a partir de cerca de $11 \mathrm{mil}$ anos AP. A subdivisão do período arcaico representa uma referência inicial e deve ser adaptada e justificada em trabalhos futuros na medida em que mais datações surgirem. O momento em que a cerâmica aparece pode variar de região para região: a data de 2.000 anos AP foi adotada como início das culturas ceramistas na Província em função de dados obtidos em pesquisas anteriores (HENRIQUES, 2006). Pelas evidências disponíveis, especialmente perfils estratigráficos, acredita-se que o surgimento dos horticultores-ceramistas ocorreu de uma maneira relativamente brusca, reforçando a idéia de uma introdução exógena.

- Pleistoceno: anterior a 11.000 mil anos AP:

- Holoceno, dividido em quatro períodos:

(1) Arcaico antigo (11.000-7000 anos AP);

(2) Arcaico médio (7000-4000 anos AP);

(2) Arcaico recente (4000-2000 anos AP);

(4) Período das culturas ceramistas (2000-500 anos AP).

Aspectos gerais das sociedades caçadoras-coletoras gerais foram levantados a partir das características do estilo nomádico de Lee e Devore (1977:11-12).

O modo de subsistência dos grupos caçadores-coletores do arcaico no contexto do Brasil Central, onde a Província Cárstica do Alto São Francisco se insere, está relacionada à exploração dos ambientes de cerrado. Restos faunísticos e vegetais recuperados de escavações na região do Brasil Central forneceram informações a respeito dos hábitos alimentares desses grupos: as populações da região foram caracterizadas como caçadores-

\footnotetext{
${ }^{14}$ Esse fato pode ter contribuído para aumentar a pressão territorial, o que talvez fez com que os grupos caçadores-coletores fossem "pressionados" a se adaptarem a áreas mais ou menos delimitadas durante períodos mais longos do que anteriormente. O estabelecimento de uma territorialidade mais estável no arcaico pode ter contribuído para a concretização de determinado tipo de organização social e econômica de grupos caçadores-coletores relativamente mais populosos aos anteriores e com redes de comunicação e troca mais extensas e duradouras, o que explicaria, em parte, a grande dispersão das tradições líticas no arcaico. Essa possível estabilização parece ter sido, em uma perspectiva arqueológica, especialmente duradoura para a população caçadora-coletora da porção sul e partes do sudeste do Brasil. Aqui pacotes contínuos de espessuras variadas, frequentemente com várias dezenas de centímetros, testemunham de uma reocupação de determinados lugares ao longo de vários milênios, desde 0 arcaico antigo até o recente, por grupos pertencentes a uma única tradição arqueológica, a Umbu (A tradição Itaparica do Brasil Central, por outro lado, parece ter tido uma duração mais curta, limitada ao arcaico antigo). As marcas mais setentrionais dessa tradição foram identificadas no estado de São Paulo, mais especificamente na bacia do rio Tietê e no vale do Ribeira.
} 
coletores generalizados, o que significa que consumiam vegetais, carne e peixe, e eventualmente também molusco de água doce. Uma diversificação do cardápio, e não especialização em um determinado tipo de caça ou vegetal, parece ter ocorrido (KIPNIS, 2002).

O tamanho de grupo tinha que ser mantido estável por causa da disponibilidade desses recursos e dos deslocamentos. A alta mobilidade não permitia um acúmulo de bens, limitando assim as diferenças de riqueza interna. Dentro do grupo, a divisão social do trabalho se baseava em tarefas diferenciadas para o homem (caçador) e a mulher (coletora), onde os recursos eram compartilhados mais ou menos igualitariamente.

Cada grupo provavelmente não constituía um sistema social fechado, mas tinha relações de comunicação, inclusive com visitas e alianças matrimoniais com outros grupos. A sociedade caçadora-coletora consistia num conjunto de grupos locais, que por sua vez pertenciam a um grupo lingüístico e reprodutivo maior. Esse agrupamento maior, no entanto, não constituía uma organização política centralizada, mas provavelmente um sistema igualitário, onde os conflitos intra-grupos poderiam ter sido freqüentes.

\section{2 - Metodologia}

A metodologia envolve a estratégia adotada pelo pesquisador, tanto em campo quanto no laboratório e da qual depende o resultado final do trabalho. Muito tempo pode ser poupado quando um plano de ação com objetivos claros é estabelecido previamente, o que nem sempre é fácil por causa do alto grau de imprevisibilidade envolvido em trabalhos arqueológicos, principalmente em regiões como a Província onde nunca foram realizadas pesquisas sistemáticas para o período arcaico.

Procurou-se aqui, além de descrever como os vestígios líticos encontrados em 13 sítios e 4 ocorrências da Província Cárstica do Alto São Francisco foram analisados, apresentar as diferentes atividades desenvolvidas durante o andamento do projeto.

\subsection{1 - Campo}

O projeto Província Cárstica de Arcos, Pains e Doresópolis: Desenvolvimento Sustentável (IGC/UFMG) possibilitou a realização de várias etapas de campo ao longo do ano de 1999 . O objetivo foi a retomada dos levantamentos de sítios arqueológicos, que desde os anos 1970 haviam sido abandonados. O levantamento arqueológico continuou nos anos seguintes sem apoio institucional, por iniciativa de uma equipe de arqueólogos de Belo Horizonte. A partir de uma cooperação frutífera entre arqueólogos e espeleólogos, vários novos sítios arqueológicos 
foram descobertos, inclusive em pontos afóticos de cavernas. Hoje tem-se um registro de pelo menos 192 sítios arqueológicos na região.

As principais atividades de campo realizadas no âmbito do presente projeto foram coletas sistemáticas e pontuais de superfície e topografia (com estação total ou bússola e trena) dos principais sítios, sendo que em dois deles foram realizadas sondagens de $1 \mathrm{~m}^{2}$ e escavações amplas: isso ocorreu na Loca do Suim e na Gruta do Marinheiro. As escavações nesses sítios estão descritas mais detalhadamente no Capítulo 4 sobre os sítios arqueológicos.

O objetivo inicial das escavações foi obter uma amostra lítica pré-cerâmica proveniente de níveis que permitiriam uma datação radiocarbônica e em quantidades suficientes para uma análise tecno-tipológica. Diferentes áreas da caverna, com exceção das partes afóticas (totalmente escuras o dia inteiro), foram escavadas para possibilitar a identificação de eventuais locais com atividades diferenciadas dentro do mesmo sítio. Assim, as escavações foram realizadas tanto nas partes que permanecem secas o ano todo, reconhecidas pelo sedimento pulverulento e seco superficial (frequentemente constituído por cinzas de fogueiras antigas), como também em locais no limite da área abrigada que, com maior ou menor intensidade, são atingidas pelas chuvas, apresentando um sedimento mais orgânico e úmido.

As escavações foram realizadas por níveis arbitrários de 5 ou $10 \mathrm{~cm}$ e todo sedimento retirado foi peneirado no próprio sítio (malhas de $3 \mathrm{~mm}$ e $5 \mathrm{~mm}$ ). Para o registro dos vestígios foram utilizadas fichas contendo número de proveniência (NP), nome do sítio, tipo de vestígio, setor, nível, data e nome da pessoa responsável pelo preenchimento. Com exceção de peças mais significativas (como as pontas de projétil, raspadores, etc.) que tiveram sua posição tridimensional registrada, o material lítico foi separado apenas por nível arbitrário. As eventuais estruturas como buracos, estruturas de combustão, sepultamentos, assim como os principais perfils estratigráficos tiveram também um registro mais detalhado em desenhos (escala de 1/10 ou $1 / 5 \mathrm{~cm}$ ), descrições e fotos. A coleta de carvões ocorreu com bastante cuidado de registrar a posição exata e condição geral em que foram descobertos; aqueles carvões associados a bioturbações ou possíveis raízes queimadas foram encaminhados para a peneira (ou seja, foram coletados por nível).

\subsection{2 - Laboratório.}

Em laboratório foi realizado a análise lítica que teve como finalidade apresentar a amostra de uma maneira organizada para a identificação de suas principais características, abrangendo elementos como a tipologia, a tecnologia, além de aspectos espaciais e cronológicos. Ela englobou tanto aquelas peças mais elaboradas do ponto de vista tecnológico e estético, quanto o refugo gerado durante os lascamentos. Devido à grande quantidade de 
peças obtidas nas escavações da Gruta do Marinheiro, mais de 22 mil, não foi possível realizar uma análise exaustiva de todo refugo recuperado desse sítio: uma solução mais ágil teve que ser encontrada para processar essa enorme amostra (em termos numéricos).

\subsubsection{1 - Análise tipológica:}

A análise tipológica constitui a principal ferramenta descritiva deste trabalho e possibilita a criação de diferentes tipos a partir da escolha de atributos considerados relevantes. $O$ importante é definir tipos que são mutuamente excludentes, ou seja, com características bem delineadas (ANDREFKY, 2001:8). O agrupamento permite descrever o conjunto da amostra sem a necessidade de apresentar cada peça individualmente.

Essa análise pode fornecer informação temporal quando um quadro tipológico regional está disponível, o que não é o caso para o material lítico da Província. Por outro lado, os tipos, principalmente os instrumentos, foram usados como marcadores espaço-temporais para regiões mais amplas do território nacional.

Vale ressaltar que o material proveniente da Gruta do Marinheiro teve uma análise diferenciado devido à grande quantidade de peças. Enquanto os sítios Loca do Suim (Área 1) e Abrigo Lagoa de Peixe tiveram as peças analisadas individualmente, na Gruta do Marinheiro, uma análise mais detalhada do refugo foi reservada para apenas uma das quatro áreas escavadas, que foi o Esc. 3 - Sul. O refugo das outras três escavações (Esc. 1, Esc. 2 e Esc. 3 - Setor Norte) foi apenas quantificado por matéria-prima e nível arbitrário.

Inicialmente, a amostra da Esc. 3 - Sul foi lavada e quantificada por matéria-prima. $O$ objetivo foi identificar as diferentes rochas exploradas pelos ocupantes da região durante o período pré-cerâmico. A quantidade de tipos de matéria-prima presente na natureza é enorme e somente uma fração da variação está diretamente associada à utilização do lascamento. A rocha mais apropriada tem características como grãos muito pequenos ou microscópicos, textura lisa, muito duro e quebradiço, além de uniforme e homogêneo.

A caracterização foi realizada pela observação macroscópica, ou seja, ao olho nu ou com uma lente de pequena ampliação (4x). A partir de uma combinação de dois atributos, cor e textura, foi realizada uma separação em 6 grandes grupos: chert, quartzito, quartzo, silex diverso, calcário e argilitos/lateritas. Não foi realizado uma descrição microscópica para identificação de outras características como composição mineralógica e tamanho dos grãos, o que geralmente é utilizada para a localização das áreas fonte (ANDREFSKY, 1998: 40-58).

As rochas (também referida como pedra ou "lítico") são conjuntos de minerais sólidos, que por sua vez são combinações de elementos químicos. Segundo William Andrefsky (1998:40-41), one of the easiest ways to identify and classify rocks is to understand the genesis 
or manner in which rocks are formed. As características como cor, textura, etc., portanto, estão diretamente ligadas aos processos de formação das rochas, que podem ser ígneas, sedimentares ou metamórficas, todas as quais são encontradas na Província ou no seu entorno.

Depois dessa separação inicial por matéria-prima, estabeleceu-se uma divisão entre os vestígios lascados e os encontrados brutos (matéria-prima sem negativos). Uma quantidade significativa de peças naturais de calcário e chert, ou seja, sem nenhuma transformação, foram excluídas da amostra devido ao fato que ocorrem naturalmente misturado no sedimento ${ }^{15}$. Por outro lado, dezenas de plaquetas de quartzito (apenas quebradas) foram introduzidas na Gruta do Marinheiro. As plaquetas brutas de quartzito tiveram duas medições, a espessura e o comprimento máximo. Elas foram utilizadas, especialmente as mais delgadas, como suporte para a fabricação de pontas de projétil.

O material lascado foi, em seguida, dividido em dois grandes grupos a partir da presença ou ausência de retoques: os suportes retocados foram classificados como instrumentos ou ferramentas, enquanto o restante foi agrupado sob a categoria de refugo de lascamento, com ausência de talhe e retoque, representado por lascas inteiras, fragmentos de lasca, núcleos e fragmentos diversos (outros). A partir de diferenças tecnológicas, morfológicas e de dimensão observadas nos artefatos ${ }^{16}$ foram criados 16 principais tipos.

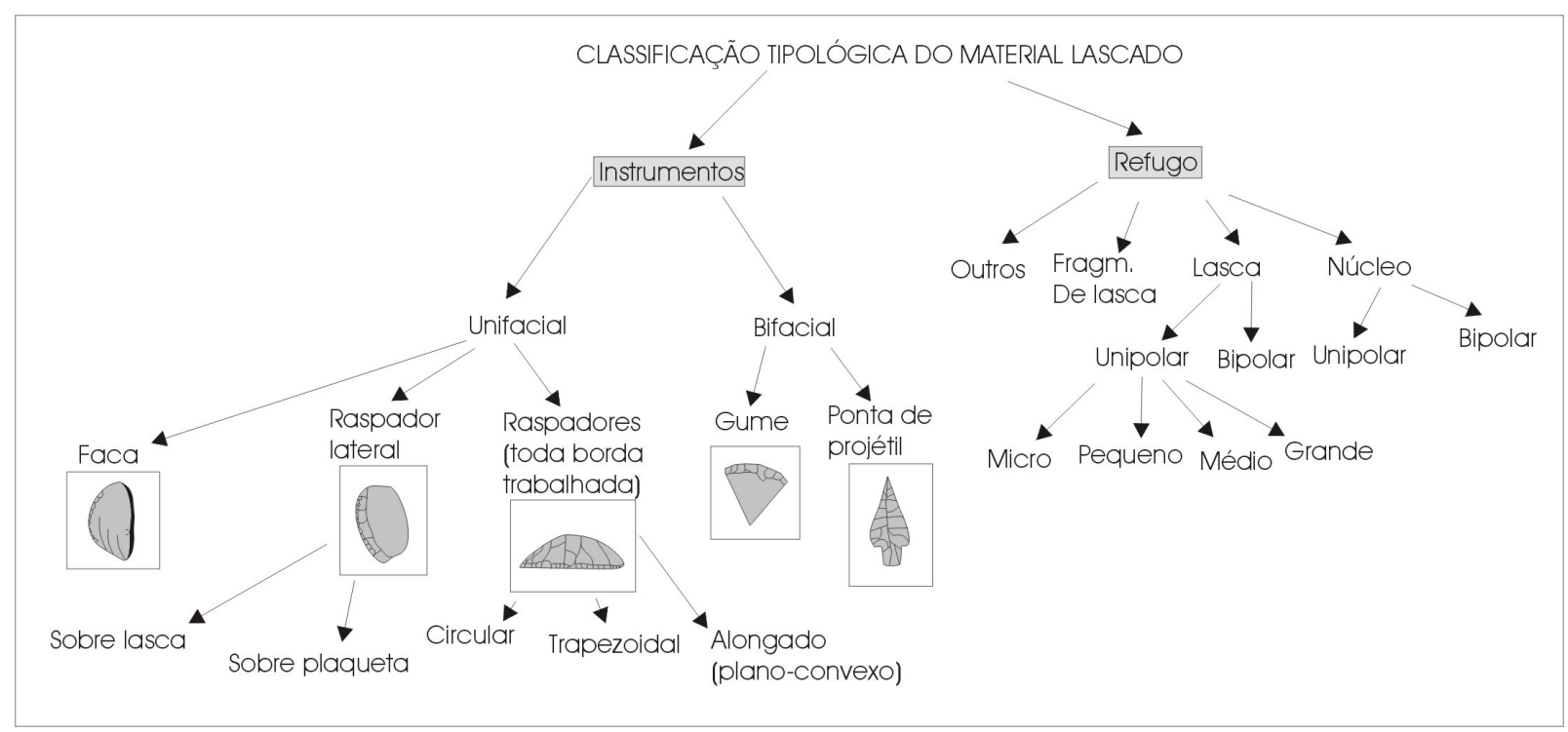

\footnotetext{
${ }^{15}$ As peças de chert com pelo menos um negativo de retirada foram enquadradas como núcleos.

${ }^{16}$ A observação neste trabalho ocorreu ao olho nu ou com a ajuda de uma pequena lente manual (4x).
} 
a) Análise tipológica dos suportes retocados (instrumentos)

Os instrumentos lascados foram subdivididos em duas principais categorias: peças unifaciais e bifaciais. Eles foram produzidos a partir de uma lasca (de seixo ou nódulo) ou plaqueta, chamado de suporte, pelo lascamento por percussão e/ou pressão, apresentando algum tipo de retoque. Note-se que essa descrição não inclui as lascas com um gume natural afiado e sem retoques, que poderiam ter sido utilizadas como ferramentas, tais como as de corte, por exemplo. Por outro lado, algumas peças com pequenos retoques ao longo da borda mais delgada, um claro sinal de reforço de um gume naturalmente cortante, foram incluídas nessa categoria, como faca com gume unifacial ${ }^{17}$.

\section{Peças unifaciais:}

Como o próprio nome sugere, somente uma face do suporte apresenta negativos de retiradas de lascas. Entre essas peças encontram-se dois principais tipos: aqueles que foram trabalhados ao longo de toda borda apresentando formas alongadas (plano-convexos), circulares e trapezoidais; e aqueles com um gume limitado a uma borda lateral. Trata-se de raspadores laterais e facas que podem atender a funções como raspar e/ou cortar.

Para a caracterização dos instrumentos unifaciais foram examinadas as seguintes variáveis:

- Matéria-prima; tipo de suporte (lasca ou plaqueta).

- Estado de conservação: alterações térmicas e fraturas; grau de preservação.

- Dimensões: comprimento, largura e espessura máxima.

- Talão (quando possível).

- Face externa: quantidade, dimensões e orientação dos negativos, distinguindo aqueles resultantes da debitagem do suporte, daqueles do talhe e retoque da peça.

\footnotetext{
${ }^{17} \mathrm{O}$ que ocorreu para algumas peças encontradas na Loca do Suim.
} 


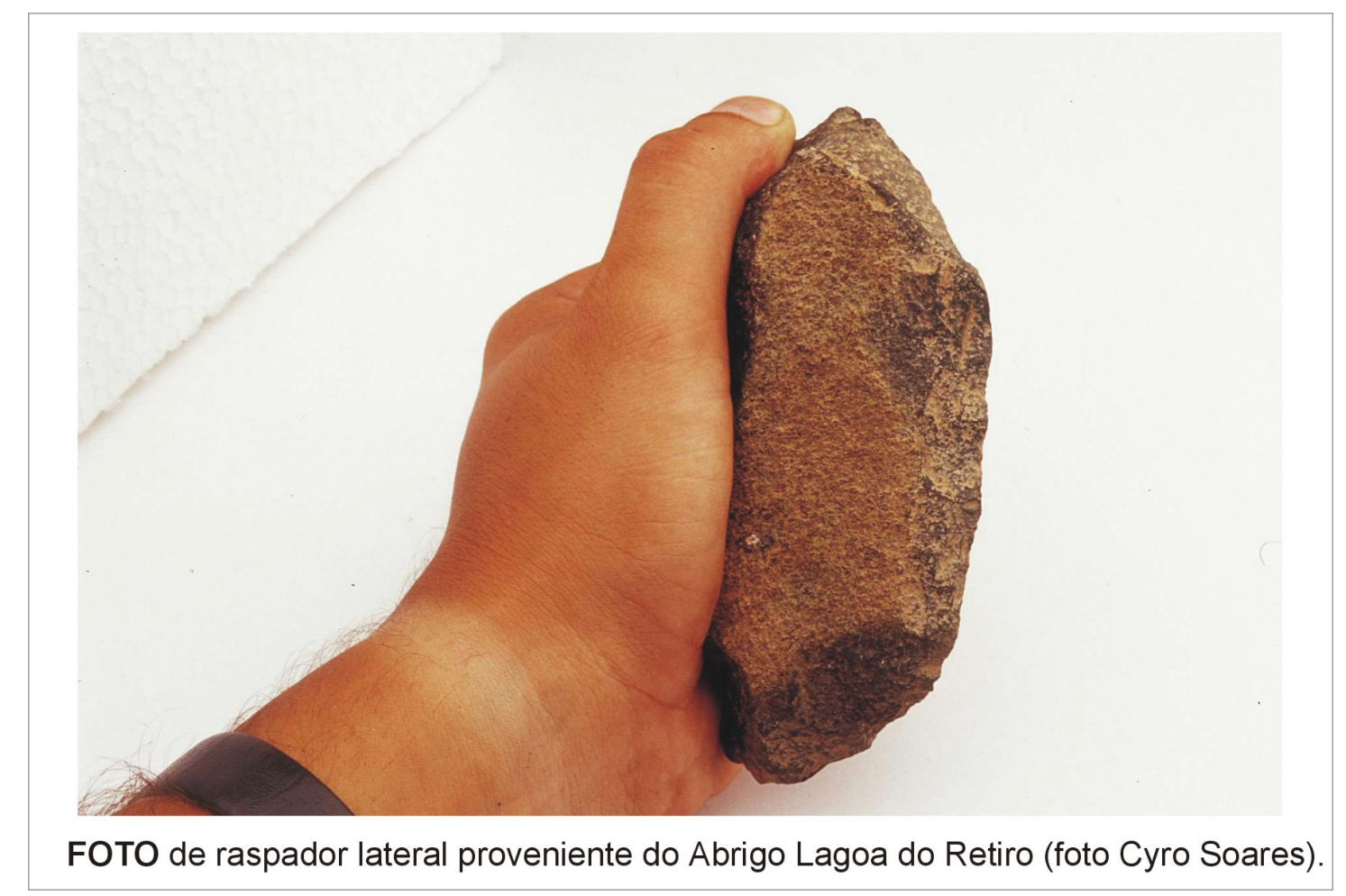

Tem-se consciência de que as formas recorrentes, principalmente no que concerne os instrumentos unifaciais, não necessariamente se apresentam sob sua primeira forma acabada. Essas peças podem ter sido reavivadas, transformadas e reduzidas ao longo do processo de utilização (finished artifact fallacy FOGAÇA, 2001:124). Por outro lado, a falta de uma forma predominante pode sugerir que se trata de instrumentos expedientes que têm em comum a presença de gumes unifaciais.

\section{Peças bifaciais:}

Apresentam negativos em ambas as faces. As pontas de projétil, inteiras ou fragmentadas, e os gumes bifaciais entram nesse agrupamento e servem para furar e cortar, respectivamente. Para a caracterização dos instrumentos bifaciais foram examinadas as seguintes variáveis:

- Matéria-prima; tipo de suporte (lasca ou plaqueta).

- Estado de conservação: alterações térmicas e fraturas; grau de preservação.

- Dimensões: comprimento, largura e espessura máxima.

- Caracterização das aletas, pedúnculos e forma das bordas para as pontas de projétil; caracterização dos gumes, no caso das facas bifaciais.

- Dimensões dos negativos. 
b) Análise tipológica do refugo de lascamento

Muitas vezes os instrumentos não são encontrados nos sítios onde foram lascados. No entanto, as lascas que foram retiradas, testemunhas da transformação dos suportes, foram descartadas e permaneceram no local, podendo ser resgatadas pela escavação e coleta.

Através da caracterização do tipo de refugo é possível inferir quais etapas da cadeia operatória estão representadas no sítio, seja associada à debitagem de núcleos ou à transformação de suportes (ver análise tecnológica ${ }^{18}$ ). Como detrito de lascamento foram identificados fragmentos de lascas, lascas inteiras, núcleos, além de fragmentos diversos como e cassons e fragmentos térmicos. Apesar dessa variedade escolheu-se desenvolver a análise, por causa da grande quantidade de peças, com aquele tipo que oferece maior potencial informativo, ou seja, com as lascas inteiras, enquanto os outros tipos de refugo apenas foram quantificados e pesados por nível. A lasca, refugo da fabricação de instrumentos (unifaciais e bifaciais) ou de debitagem de núcleos (unipolares e bipolares), é o tipo de vestígio mais numeroso encontrado. A seguir, uma descrição das principais características desse tipo de refugo.

$\mathrm{Na}$ análise tipológica das lascas inteiras foram, em primeira instância, diferenciadas as lascas unipolares das bipolares, sendo que essa última técnica foi encontrada quase que exclusivamente no quartzo. A fabricação dos instrumentos, tanto unifaciais quanto bifaciais, é caracterizado pelo lascamento unipolar. Teve-se a preocupação de tentar identificar, de uma maneira qualitativa, as diferenças nas lascas unipolares produzidas pelo lascamento unifacial e pelo bifacial. As pontas de projétil, que representam a maior parte dos instrumentos bifaciais, são em geral caracterizadas pelo acabamento por pressão: uma forma de lascamento que exige muita força mas que permite uma maior precisão das retiradas e que produz em geral lascas menores do que aquelas obtidas por percussão, para a produção dos raspadores unifaciais por exemplo. Pode-se supor, portanto, que separando as lascas unipolares inteiras por tamanho (comprimento segundo eixo tecnológico), ocorre também uma separação tecnológica: as maiores associadas à produção de ferramentas unifaciais ou obtidas a partir de núcleos; as menores associadas à produção de pontas de projétil bifaciais ${ }^{19}$. Os grupos de tamanhos escolhidos foram (DIAS, 1994:104-105):

- Microlascas: até $1 \mathrm{~cm}$ de comprimento;

- Lascas pequenas: entre 1 e 2,5 cm;

\footnotetext{
${ }^{18}$ Esse item discute as etapas da cadeia operatória de lascamento e os tipos de vestígios associadas a cada uma delas.

${ }^{19}$ Essa análise foi realizada apenas para o material da Esc. 3 - Sul.
} 
- Lascas intermediárias ou médias: entre 2,5 e 4cm;

- Lascas grandes: entre 4 e $7 \mathrm{~cm}$ (ou mais).

Outro tipo importante de refugo lascado é o núcleo. Desse são retiradas as lascas que servirão como instrumentos ou como suporte para a produção de ferramentas. Às vezes, os núcleos são reformatados e utilizados como ferramentas. Os núcleos podem ser anárquicos ou organizados - no primeiro caso não há uma padronização aparente das lascas retiradas; no segundo caso, as lascas têm uma forma predeterminada e recorrente. Os núcleos podem ser organizados em dois grupos, de acordo com a técnica utilizada: núcleos unipolares ou bipolares.

- Unipolar: os núcleos que foram lascados pela percussão unipolar são geralmente maiores que os núcleos bipolares e podem assumir uma variedade de formas: piramidal, bipiramidal, carapaça de tartaruga, cunha, tabular, cônico e poliédrico.

- Bipolar: essa técnica está freqüentemente associada a uma matéria-prima de tamanho reduzido como pequenos prismas ou seixos de quartzo, mas também pode ser que tenha sido utilizada para aproveitar peças descartadas de outras matérias-primas.

Buscou-se, em seguida, organizar o núcleo segundo alguns atributos:

- Matéria-prima;

- Forma do núcleo decorrente do método de debitagem.

- Dimensões

- Quantidade de planos de percussão;

- Tipos de plano de percussão: opostos, adjacentes

- Quantidade e dimensões dos negativos;

- Presença ou não de negativos de lascas refletidas;

\subsubsection{2 - Análise tecnológica:}

Acredita-se que por trás de toda produção humana se encontra um sistema de regras e procedimentos, envolvendo uma variedade de conhecimentos e gestos aprendidos que podem ser organizados por etapas. Essas etapas, que representam um encadeamento organizado (FOGAÇA, 2001:106), foram definidas para a fabricação de ferramentas de pedra lascada com base em trabalhos experimentais, incorporando à análise o refugo de lascamento. Todos os vestígios líticos pertencem, portanto, a uma cadeia operatória constituída de várias etapas, 
sendo as principais delas as seguintes: (1) obtenção de matéria-prima, (2) fabricação de ferramentas, (3) uso, (4) reutilização e (5) descarte.

a) Obtenção de matéria-prima a partir de jazidas naturais.

De uma maneira geral, os grupos caçadores-coletores utilizaram, entre outras, a pedra, em menor ou maior grau silicificada, como matéria-prima para a fabricação de ferramentas lascadas (PROUS, 1992). As peças com retoque mais refinado e com formas padronizadas são geralmente matérias-primas de melhor qualidade, entre as quais se destacam, para a Província Cárstica do Alto São Francisco, variedades de quartzito e silex, e quartzo. Essas rochas apresentam dureza e flexibilidade adequadas, além de uma alta homogeneidade, permitindo um maior controle e precisão nos golpes.

Os sítios de extração de matéria-prima apresentam freqüentemente blocos com negativos de retiradas. Podem apresentar vários tipos de lascas, dependendo do investimento depositado na preparação de suportes no local.

b) Fabricação das ferramentas

A produção de utensílios de pedra através de lascamento pode ser realizada por duas principais técnicas ou com uma combinação das duas: lascamento por percussão (direta e indireta) e lascamento por pressão.

A primeira técnica envolve um golpe exercido com um batedor, geralmente de uma pedra mais dura, mas também de madeira ou chifre, sobre a pedra, seja direto ou indireto, obtendo-se assim lascas. As lascas podem representar diferentes etapas na fabricação: debitagem para eliminar o excesso de volume, ou obtenção de um suporte e lascas de talhe, em caso de formatação (façonnage) de alguma ferramenta. As lascas de retoques podem ser produzidas por essa técnica durante a fase final de lascamento, na preparação do gume que se pretende utilizar. Micro-lascas e estilhaços são produzidas ao longo de todo processo; as primeiras, quando em quantidades maiores, também podem caracterizar o lascamento por pressão, para a produção de pontas de projétil bifaciais por exemplo.

Nessa segunda técnica, o lascamento por pressão, geralmente associado ao acabamento de gumes, é obtido com uma pressão exercida sobre a pedra, retirando pequenas lascas (lascas de retoque) com maior precisão do que possível com o lascamento por percussão, diminuindo também os riscos de quebra do suporte. 
c) Uso.

As ferramentas podem ser utilizadas para cortar, rasgar, amassar, etc. A morfologia da peça em alguns casos é reveladora nesse sentido. Uma ponta de projétil, por exemplo, serve para perfurar, uma função óbvia pelo formato desse objeto. Em outros casos, a função não é tão evidente, como para uma variedade de raspadores unifaciais, retocados ou apenas com marcas de utilização (com parte ativa lateral e/ou final, ou circular).

A reavivagem (manutenção) do gume permite prolongar a durabilidade das ferramentas através da obtenção de novos gumes em substituição aos gumes desgastados. Foram elaborados conceitos que diferenciam ferramentas que tiveram maior investimento de energia e tempo (curated) daquelas com menor (expedient). Segundo Odell (1996:53), apesar de algumas variações nas definições, o conceito de curated é geralmente utilizado para designar uma relação que maximiza a vida útil de uma ferramenta dentro de um sistema cultural de populações de caçadores-coletores. Essa estratégia engloba também peças quebradas aproveitadas para outras funções (ver item abaixo sobre reutilização).

[..] uma organização tecnológica baseada em estratégias de curadoria proporciona um aumento da expectativa de vida dos artefatos, apresentando altos índices de reciclagem das peças quebradas para produção de outros itens materiais. Uma organização tecnológica baseada em estratégias expedientes, por sua vez associa-se à produção de artefatos em função de necessidades imediatas, com o posterior descarte das peças nas áreas de atividade. As conseqüências materiais de uma organização tecnológica de curadoria centram-se na ausência de relação direta entre artefatos e áreas de atividade específicas e em altos índices de investimentos tecnológicos na produção e manutenção dos artefatos, que são produzidos em antecipação ao uso e descartados em baixa freqüência [plano-convexo esgotado?]. Por outro lado, organizações tecnológicas expedientes apresentam uma relação mais positiva entre área de atividade $e$ descarte nos sítios (DIAS, A., 2003:224).

d) Reutilização.

O reaproveitamento de objetos descartados ou a mudança de função representa uma reutilização oportunística de determinadas matérias-primas em caso de necessidade (também por grupos separados cronologicamente) $)^{20}$.

\footnotetext{
${ }^{20}$ Raspadores unifaciais de quartzo foram, por exemplo, reaproveitados como núcleos bipolares.
} 


\section{e) Descarte.}

O destino final das ferramentas depois de acabadas (ou não) todas possibilidades de aproveitamento delas é representada pelo descarte. O abandono e a perda são outras possibilidades pelas quais os objetos podem entrar em um contexto arqueológico.

A identificação da(s) cadeia(s) operatória(s) a partir de uma amostra lítica é realizada pelo reconhecimento de tipos de vestígios como suportes retocados, lascas, lascas fragmentadas, fragmentos de lascas, núcleos, etc. e pela caracterização deles a partir da análise de atributos como morfologia, matéria-prima, comprimento, largura, espessura, peso, etc. De uma forma geral, as dimensões e peso das peças e a quantidade de córtex tendem a se reduzir ao longo do processo de fabricação.

\subsubsection{3 - Análise cronológica:}

O material foi trabalhado a partir de unidades de análise ou conjuntos. Cada conjunto é uma delimitação espacial, representado por vestígios de um mesmo nível arbitrário de 5 ou 10 $\mathrm{cm}$, provenientes da escavação de uma unidade ou de uma área mais ampla. Os conjuntos foram em seguida comparados entre si para a análise cronológica, a qual levará em conta características ligadas à formação do registro arqueológico como declive do terreno, presença de raízes, pisoteamento e (eventual) associação a estruturas de combustão e estruturas escavadas como buracos e enterramentos humanos. Finalmente, a datação de carvões associados a alguns conjuntos forneceram um quadro temporal com datas absolutas.

Cada conjunto a ser analisado pode apresentar mais de uma cadeia operatória. Isso acontece quando ferramentas tecno-tipológicamente distintas são produzidas em um mesmo local e em momentos próximos, por exemplo. Em geral, apenas fragmentos da(s) cadeia(s) são identificados no mesmo sítio.

Freqüentemente encontra-se camadas arqueológicas bastante homogêneas em termos de cor e textura, onde os diferentes momentos de ocupação não são distinguíveis, porque se sobrepõem e se misturam. Nesse caso, o uso de níveis arbitrários torna-se interessante, na medida em que pode buscar continuidades e rupturas dentro de uma camada arqueológica à primeira vista bastante homogênea.

A análise cronológica se concentrará no estudo da variabilidade tecnológica (BUENO, 2005) entre esses conjuntos associado às datações radiocarbônicas. Apesar dessa divisão, um conjunto de vestígios e estruturas associados espacialmente, em uma estrutura fechada como nos sepultamentos da Loca do Suim, podem atravessar diversos níveis arqueológicos. Nesse 
caso, os vestígios encontrados nos níveis ou sub-níveis pertencentes a um mesmo sepultamento por exemplo, podem posteriormente serem agrupados em um único conjunto.

Todas escavações foram registradas com ficha de nível $(10 \mathrm{~cm})$ ou sub-nível $(5 \mathrm{~cm})$, fotos, desenhos de planta baixa com localização tridimensional dos vestígios por tipo $(x, y, z)$ e posicionamento das estruturas, além de desenhos dos perfils estratigráficos. O objetivo foi recuperar o máximo possível de informações, permitindo boas representações da estratigrafia, das relações horizontais e verticais entre os vestígios e estruturas e dos processos pósdeposicionais. Buscou-se registrar a relação espacial, tanto horizontal quanto vertical, entre vestígios e/ou estruturas dentro de um mesmo sítio (CLARKE, 1977).

As escavações foram realizadas em diferentes locais dentro dos sítios, permitindo assim amostrar diferentes áreas da caverna ou abrigo para fornecer uma melhor visão arqueológica do conjunto, com a possibilidade de identificar áreas de atividades diferenciadas. 


\section{CAPÍTULO 2 - AS PRINCIPAIS INDÚSTRIAS LÍTICAS ARCAICAS DO BRASIL}

As indústrias líticas do arcaico no Brasil são caracterizadas por marcadas homogeneidades [..] que coincidem com largas extensões geobiológicas parecendo as fronteiras coincidir com os limites dessas regiões naturais como se houvesse uma forte tendência adaptativa das populações (SCHMITZ, 1991:3). Três grandes tradições líticas foram descritas para o arcaico no Brasil, uma que tem seu epicentro no Brasil Central e duas na porção sul do país.

\section{1 - Brasil Central}

Trata-se de uma região de grandeza espacial com cerca de dois milhões de quilômetros quadrados (desde Mato Grosso, Goiás, Tocantins, até áreas com cerrados no oeste da Bahia, norte e oeste de Minas Gerais), de clima tropical com duas estações bem definidas, uma chuvosa e outra seca, e dominada pela vegetação do cerrado.

"Cerrado" is a mosaic of different types of savanna crossed by streams usually with narrow gallery forests, and with occurrences of swamps, marshes, and small lakes at the headwaters of rivers and creeks [...]. In Central Brasil "cerrado" [...] can be subdivided into five physiognomic vegetation types with increasing density of trees [...] (KIPNIS, 2002:69)

A principal indústria arcaica associada à região do Brasil Central é conhecida como tradição Itaparica, caracterizada por um lascamento unifacial dominante, apresentando instrumentos típicos como plano-convexos e lesmas (ver foto e desenho abaixo de um exemplar de plano-convexo proveniente do sítio Casa de Força, Centralina, no triângulo mineiro).

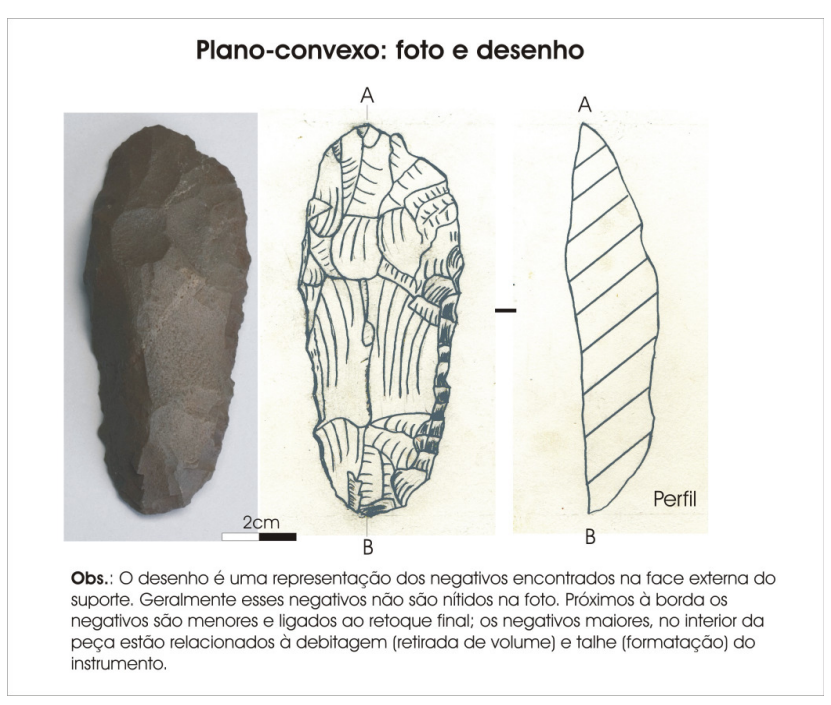


Nos últimos 40 anos foram realizados vários projetos arqueológicos no Brasil Central. As indústrias líticas identificadas na região são bastante homogêneas, principalmente para o arcaico antigo, entre cerca de 12mil e 9 mil anos AP (BUENO, 2005).

É uma indústria sobre lascas elaborada a partir de matérias-primas selecionadas e de excelente qualidade - como sílex e algumas variedades muito finas e homogêneas de arenito silicificado - que, [...], representam a principal distinção entre as camadas mais antigas e as demais. A seleção de matérias-primas de melhor qualidade está associada a uma tecnologia onde a maior exigência formal na produção dos artefatos requer um retoque fino e, ocasionalmente, um trabalho bifacial nos suportes. [...] Destaca-se na indústria os conhecidos artefatos planoconvexos, com ampla distribuição por todo o Planalto Central Brasileiro e as pontas de projéteis bifaciais, mais raras. DeBlasis e Robrahn-González (2003) sugerem que a característica mais marcante da indústria desses assentamentos mais antigos de caçadores e coletores seja essa clara opção pela produção de artefatos formalmente bem definidos. Um dos principais artefatos identificados são as chamadas lesmas - artefatos plano-convexos, sobre lasca ou seixo, elaborados com acabamento meticuloso, ferramentas tipicamente associadas à Tradição Itaparica do Planalto Central e encontradas de maneira sistemática até cerca de 10.000 anos atrás (MORALES, 2005: 19-20).

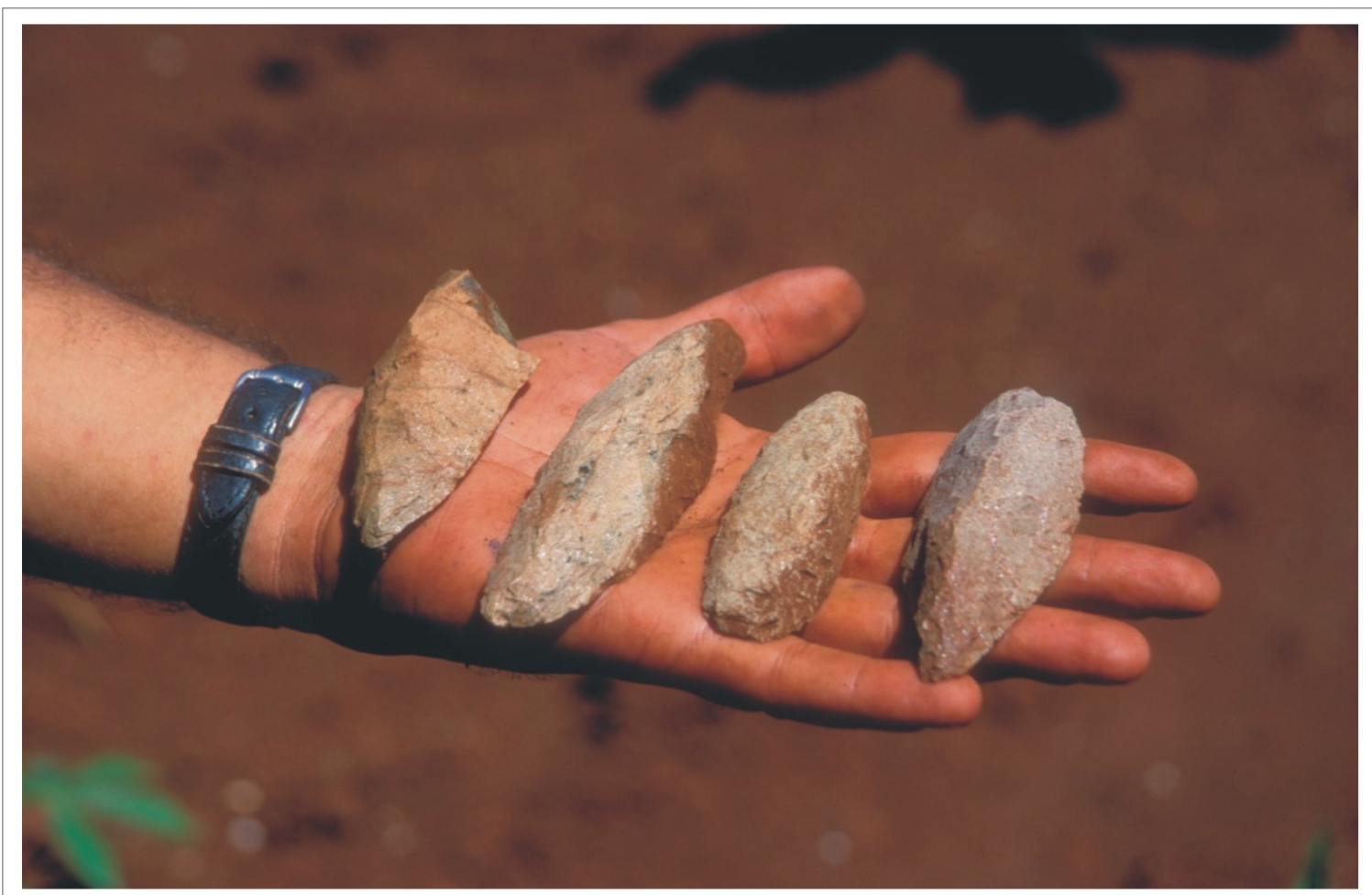

FOTO de plano-convexos de arenito provenientes de sítio a céu aberto no triângulo mineiro, município de Monte Alegre de Minas. 
O período seguinte, o arcaico médio, é caracterizado por caçadores-coletores, possivelmente já em processo de transição para a adoção da horticultura como complemento alimentar à caça e coleta. Em termos tecnológicos, a "sofisticação" do período antigo é substituída por uma indústria lascada pouco elaborada e sem preocupação de padronização formal. Apesar de menos presente, a produção de peças tanto unifaciais quanto bifaciais não desaparece por completo.

Trata-se basicamente de uma indústria expediente, aparentemente não muito distinta das características tecnológicas da indústria lascada dos grupos ceramistas e semelhante à indústria de muitos sítios líticos encontrados em superfície. No entanto há indícios de que certas características tecnológicas típicas do horizonte mais antigo, principalmente a produção de artefatos bifaciais, continuam presentes nessa época.[...] Essa indústria lítica associada a fase Serranópolis seria caracterizada pela substituição das peças bem trabalhadas pelas "lascas com pequenos bordos denticulados, bicos, pontas-entre-entalhes ou simplesmente com bordos regularizados". "Desaparecendo o fino acabamento dos raspadores, desaparecem também as características lascas de redução secundária, antes encontradas em grande quantidade, mas mantêm-se os artefatos unifaciais, embora muito menos trabalhados.[...] Bueno (2003) sugere que essa indústria utiliza, quase que exclusivamente, as matérias-primas disponíveis localmente (MORALES, 2005:22-23).

\subsection{1 - As Regiões Cársticas de Minas}

As áreas cársticas de Minas localizadas na bacia do rio São Francisco se inserem na porção sudeste do Planalto Central Brasileiro ou Brasil Central. As pesquisas relacionadas às áreas cársticas têm sido o principal foco de interesse da arqueologia em Minas Gerais ao longo de várias décadas. As duas regiões com maior quantidade de escavações e publicações, ambas situadas na bacia do rio São Francisco, são a Região de Lagoa Santa, localizada no centro (HURT \& BLASI, 1969; WALTER, 1948 e 1958; PROUS, 1992; CPRM, 1998) e os Vales dos Rios Peruaçu e Cochá, no norte do estado (PROUS, 1996/1997; FOGAÇA, 2001). A Província Cárstica do Alto São Francisco está a 250km (em linha reta) da Região Cárstica de Lagoa Santa e a cerca de 500km do vale do rio Peruaçu.

\subsubsection{1 - Região de Lagoa Santa.}

O interesse pela arqueologia em Minas Gerais foi pioneiro no Brasil, datando da primeira metade do século XIX. No entanto, limitou-se durante muito tempo apenas à área cárstica de Lagoa Santa. O naturalista dinamarquês Peter Wilhelm Lund visitou ali mais de 800 cavernas entre os anos de 1835 e 1844, explorando possivelmente mais de 200 grutas (O CARSTE, janeiro 2002). O objetivo principal desse pesquisador eram os fósseis de animais, depositados 
nos sedimentos das cavernas. Dr. Lund achou 16 gêneros de animais extintos, em 6 locais encontrando também restos de ossos humanos de pelo menos 30 indivíduos misturados com uma grande quantidade de ossos de animais, tanto extintos quanto ainda existentes (HURT, 1987). Na Lapa do Sumidouro em Pedro Leopoldo ele encontrou, além dos ossos humanos, instrumentos de pedra, atribuídos aos antigos habitantes da região. Também parece ter sido o primeiro a mencionar, em uma carta de 1837, as pinturas rupestres da região de Lagoa Santa (CPRM, 1998).

A problemática introduzida pelo pesquisador refere-se à antigüidade da presença humana no novo mundo e, mais especificamente, à contemporaneidade de animais extintos ou antediluvianos com os antigos habitantes do continente americano. As pesquisas, registradas em relatórios à Sociedade Científica de Copenhague, revelaram a possibilidade de que o homem da região de Lagoa Santa fosse contemporâneo a esses animais.

A descoberta de Lund era pioneira para a época, num contexto intelectual que antecedia à publicação do trabalho de Charles Darwin sobre a evolução das espécies e à aceitação plena da existência de um período pré-histórico longo na Europa, com as pesquisas de Boucher de Perthes. Suas pesquisas contudo, não tiveram repercussões imediatas na Europa; somente algumas décadas mais tarde, quando se encontraram restos humanos associados á fauna extinta do Velho Mundo, o "Homem de Lagoa Santa" tornou-se célebre (CPRM, 1998).

A aceitação pela comunidade científica, na segunda metade do século XIX, da grande antigüidade do homem no continente europeu, abriu caminho para a busca dos antigos habitantes das Américas. As primeiras evidências arqueológicas incontestáveis apareceram em 1927, quando J.D. Figgins descobriu uma ponta de projétil entre as costelas de um bisão gigante (Bison antiquus) próximo à cidade de Folsom, nos Estados Unidos. As datações obtidas nos anos 1950 colocaram a cultura Folsom entre 11 mil e 10 mil anos AP (FIEDEL, 1996:68105).

A comprovação da grande antigüidade dos vestígios da região de Lagoa Santa, no entanto, só se deu décadas depois, no final dos anos 1960, através da datação radiocarbônica de carvões provenientes do Complexo Cerca Grande, onde foram escavados seis abrigos. $O$ projeto de escavação foi iniciado em 1955 pela Universidade South Dakota dos Estados Unidos e o Museu Nacional do Brasil, coordenado pelo norte-americano Wesley Hurt e o brasileiro Oldemar Blasi. No Abrigo VI, com $20 \mathrm{~m}^{2}$ escavados, foram obtidas datações para as camadas inferiores entre $10378 \pm 122$ AP e $9720 \pm 128$ AP (resultados publicados em abril de 1969). Desse período datam alguns sepultamentos, uma grande quantidade de lascas de quartzo de lascamento bipolar, núcleos bipolares, alguns raspadores de silex, pontas de projétil bifaciais e machados lascados (PROUS \& FOGAÇA, 1999:25-26). 
Antes da divulgação dessa descoberta várias outras escavações foram realizadas na região por arqueólogos profissionais e amadores.

Entre 1926 e 1929, Padperg-Drenkpol, do Museu Nacional do Rio de Janeiro escavou cinco lapas na região. O pesquisador não se convenceu da contemporaneidade entre o homem pré-histórico e a fauna desaparecida.

A Academia de Ciências de Minas Gerais, composta pelos pesquisadores Anibal Mattos, Arnaldo Cathoud, Josaphat Pena e H.V. Walter, ao longo de cerca de 25 anos (desde os anos 1930) escavou pelo menos 10 cavernas na região. Ao contrário de Padperg-Drenkpol, eles eram favoráveis à tese da grande antigüidade do homem e da contemporaneidade dele com os animais extintos. Os trabalhos tiveram várias publicações e uma hipótese foi apresentada para a ocupação pré-histórica, dividida em quatro períodos (WALTER, H.V., 1958): dois momentos précerâmicos e dois cerâmicos. Descreveram também os tipos de artefatos provenientes das camadas mais profundas, "marcadas" pela ausência de cerâmica. No entanto, a metodologia adotada não permitiu um registro mais detalhado, principalmente de perfils estratigráficos, que poderiam apoiar essas afirmações.

O período pré-cerâmico na região de Lagoa Santa foi caracterizado por vestígios como instrumentos (e refugo) de pedra, ferramentas de osso e madeira, e ossadas humanas. As principais ferramentas de pedra descritas por H.V. Walter para o pré-cerâmico são as pontas de projétil e as machadinhas lascadas. Ambos os tipos foram situados cronologicamente a partir de datações radiocarbônicas no sítio Cerca Grande VI. No entanto, a maior parte da amostra de pontas de projétil da região, proveniente da coleção Walter com mais de 70 peças (COSTA, 1998), não puderam ser datadas.

O refugo de lascamento não teve uma análise detalhada e foi apenas mencionado. As pontas foram confeccionadas a partir de osso, madeira e pedra (essa última H.V. Walter atribui também a períodos mais recentes). Os machados e machadinhas de pedra, completamente lascados ou parcialmente polidos nos gumes, foram interpretados por H.V. Walter como predecessores dos instrumentos bem acabados, simétricos e totalmente polidos, atribuídas aos horticultores-ceramistas.

As datas antigas obtidas por W. Hurt para a região de Lagoa Santa atraíram a atenção de outros arqueólogos a partir do final dos anos 1960. A Missão Arqueológica Franco-Brasileira, coordenada pela francesa Annette Laming-Emperaire, começou suas pesquisas em Lagoa Santa no início dos anos 1970 com trabalhos de prospecção e sondagens em diversos sítios da região. A Missão também empreendeu uma escavação em grande superfície na Lapa Vermelha IV (Pedro Leopoldo), de onde foram recuperados o crânio e outros restos ósseos de uma mulher, depositados nas camadas intermediárias a $10200 \pm 220$ e $11680 \pm 500$ anos AP. As 
datações foram obtidas através de carvão disperso, de provável origem natural (queimadas). A Missão também iniciou o registro sistemático das pinturas e gravuras rupestres da região.

Deve-se à Missão a primeira datação de pintura rupestre no Brasil, que estabeleceu para uma pintura soterrada de Lapa Vermelha a idade mínima de 3.800 anos (usando a datação de C14 da camada sedimentar que a cobria), antigüidade muito maior do que até então se supunha (CPRM, 1998).

Os trabalhos da Missão em Lagoa Santa tiveram continuação com a criação do Setor de Arqueologia em 1975-76, no Museu de História Natural da Universidade Federal de Minas Gerais, sob a coordenação de André Prous. O Setor deu seqüência aos trabalhos de levantamento sistemático da arte rupestre e, nos anos seguintes, a principal escavação, realizada no Grande Abrigo de Santana do Riacho, revelou vestígios de até 12 mil anos AP (11960 \pm 250 AP - Gif 5089). Como na região de Lagoa Santa, deparou-se com vestígios líticos lascados e enterramentos humanos nos níveis pré-cerâmicos.

Os instrumentos com mais de 10.000 anos [na região de Lagoa Santa] limitam-se a poucas lascas de quartzo e a uma raspadeira retocada de calcário silicificado (esta com idade provável entre 14.000 e 20.000 anos). Numerosas plaquetas de calcário com gume natural ou de calcita foram coletadas e examinadas nos níveis pleistocênicos de Lapa Vermelha, mas não conseguimos demonstrar que 0 homem tivesse utilizado algumas delas. A indústria holocênica é, por sua vez, muito mais numerosa (CPRM, 1988:12).

O Setor forneceu uma descrição dos vestígios líticos pré-cerâmicos da região de Lagoa Santa e Santana do Riacho. O refugo de lascamento e os instrumentos menos padronizados, como raspadores e raspadeiras, tiveram um papel maior na análise graças aos procedimentos metodológicos adotados, valorizando todo processo de lascamento e aquisição de matéria-prima e não só os produtos finais ou melhor acabados. A baixa quantidade de ferramentas formais recuperadas nas suas próprias escavações (Lapa Vermelha de Pedro Leopoldo, Carroção e Grande Abrigo de Santana do Riacho), por outro lado, limitou a descrição de grande parte de sua própria amostra ao refugo de lascamento.

A análise lítica revelou a importância da técnica bipolar de lascamento, principalmente sobre quartzo, no registro arqueológico da região. Nas camadas do holoceno médio e antigo predominou o quartzo com lascas bipolares, além de lascas de debitagem unipolar e de lascas utilizadas brutas. As lascas maiores de quartzo foram retocadas em raspadores e raspadeiras. Em silex, com lascamento unipolar predominante, foram encontrados lascas e raspadores. No Grande Abrigo de Santana do Riacho também houve uma escolha preferencial do quartzo, matéria-prima que representou mais de 99\% da amostra (na Área III). Foram encontrados ali 16 
artefatos retocados de quartzo (inclusive um fragmento bifacial) e 15 peças retocadas de quartzito, uma matéria-prima local. Trata-se de peças plano-convexas e raspadores feitos a partir de plaquetas, com gumes unifaciais abruptos (JUNQUEIRA, 1984:108). Ela coexiste aqui com uma indústria bipolar de cristal de quartzo sobre lascas pequenas, parecida com o material da região vizinha de Lagoa Santa.

Como foi dito no início do capítulo, a região de Lagoa Santa mostrou-se especialmente rica em restos biológicos dos habitantes pré-históricos. Constatou-se que vários abrigos e cavernas na região foram utilizados como cemitérios, entre outros, a Lapa de Confins (ou Lapa Mortuária de Padberg-Drenkpol), Lapa Vermelha de Pedro Leopoldo, Complexo Cerca Grande (Abrigos IV e VI), e na região vizinha da Serra do Espinhaço, o Grande Abrigo de Santana do Riacho. Outros vestígios humanos são também encontrados nos sítios Caieras I/ e Lapa do Sumidouro, no entanto em contextos mais perturbados.

O Laboratório de Estudos Evolutivos Humanos (IB/USP) de São Paulo, sob a coordenação de Walter Neves, realiza escavações arqueológicas na região de Lagoa Santa desde 2001. Um dos objetivos é a recuperação de restos humanos pertencentes aos habitantes do final do Pleistoceno e início do holoceno, atribuídos à "raça de Lagoa Santa". A principal característica física dessa população, para a qual existem esqueletos de dezenas de indivíduos, com idades entre 7.000 e 11.000 anos AP, está nos crânios (NEVES, W.A. \& HUBBE, M., 2005; GONZALES-JOSÉ, R. et alii, 2005).

Comparative morphological studies of the earliest human skeletons of the New World have shown that, whereas late prehistoric, recent, and present Native Americans tend to exhibit a cranial morphology similar to late and modern Northern Asians (short and wide neurocrania; high, orthognatic and broad faces; and relatively high and narrow orbits and noses), the earliest South Americans tend to be more similar to present Australians, Melanesians, and Sub-Saharan Africans (narrow and long neurocrania; prognatic, low faces; and relatively low and broad orbits and noses (NEVES, W.A. \& HUBBE, M., 2005).

Sabe-se que esses foram utilizados pelo homem até cerca de 8000 anos AP e a partir de 3000 anos AP (ARAUJO et alii, 2005). Entre essas duas datas, os vestígios arqueológicos praticamente desaparecem na região e em outras áreas do Brasil Central, o que foi atribuído por alguns a um período de seca intensa. Trata-se de um fenômeno chamado de "archaeological gap".

An overview of the archaeological data produced over the last decades for Brazil, coupled with a background of recent paleoenvironmental studies, suggests that during the mid-holocene vast areas of Central Brazil ceased to be occupied by human groups.[...] Paleoenvironmental data suggests that dryness events constitute the major cause behind the observed trends (ARAUJO et alii, 2005). 


\subsubsection{2 - Vales do Peruaçu e Cochá.}

A ampliação da área de pesquisa, além dos limites da região central de Minas Gerais, se deu com levantamentos, coletas e escavações realizadas, a partir do final dos anos 1960, no âmbito do Programa Nacional de Pesquisas Arqueológicas - PRONAPA. A preocupação do programa foi a identificação da cultura material pré-histórica sobre uma maior área possível do território nacional, na época em sua maior parte ainda inexplorado. Os pesquisadores prosseguiam no estabelecimento de fases, agrupando-as em tradições culturais, cujos limites em vários casos extrapolavam os limites estaduais. No estado de Minas Gerais os trabalhos ficaram a cargo do Instituto de Arqueologia Brasileira - IAB, do Rio de Janeiro.

O trabalho sistemático da região [Minas Gerais] somente começou, no entanto, a partir de 1968, quando a área dos formadores mineiros do rio Paraná nos foi designada para a pesquisa, durante a reunião do PRONAPA em Belém.[...] Durante o último ano do PRONAPA (1969-1970) demos ênfase à região vizinha ao Estado de São Paulo, pesquisando o alto curso do Sapucaí e Mogi-Guaçu, iniciando, ainda, a prospecção no alto curso do rio São Francisco (DIAS Jr., 1975:10-11).

A partir de 1970, quando os trabalhos do PRONAPA cessaram, as pesquisas prosseguiram no âmbito do Programa de Pesquisas no Vale do São Francisco - PROPEVALE, no estado de Minas Gerais.

Segundo Adriana Dias (1994:9) as culturas pré-cerâmicas tinham um papel secundário no PRONAPA, devido à crença de que os sítios seriam possivelmente pequenos e pouco profundos (com exceção dos sambaquis) com estratigrafia natural limitada e sem restos arquitetônicos (EVANS \& MEGGERS, 1965:VII) e à alta velocidade empregada nos trabalhos de campo, limitava-se a amostragem geralmente a coletas de superfície com alguns poucos cortes estratigráficos (DIAS, A.S.,1994:18).

O PROPEVALE foi dividido em frentes de pesquisa, cada uma cobrindo uma porção do vale do rio São Francisco em Minas. A primeira a ser abordada foi a Frente $V$, cobrindo a área mais setentrional, do rio Cochá até a fronteira com a Bahia. Foi também nessa região, no norte de Minas, que o Setor de Arqueologia da UFMG abriu uma nova frente de trabalho, que perdurou desde os meados dos anos 1980 até o final dos 1990. Durante o projeto foram escavados e/ou sondados vários sítios sob abrigo e a céu aberto (Lapa do Dragão, Lapa do Boquête, Lapa da Hora, Lapa dos Bichos, Terra Brava, entre outros). A região Peruaçu/Cochá tem uma grande quantidade de vestígios lascados nos sedimentos escavados e, ao contrário da região de Lagoa Santa, tem excelentes variedades de sílex local. 
Nas camadas VII e VIII da Lapa do Boquête, datadas entre 12000+/-300 (CDTN 1084) e 9870+/-260 (CDTN 1077) encontrou-se uma rica indústria lítica, instrumentos de osso, estruturas de buraco e de combustão, restos alimentares, pigmentos vermelhos e sepultamentos humanos. Um grande bloco com figuras picoteadas e cúpulas polidas foram encontrados em 1995, coberto pela camada VI e uma fogueira datada em $9350+/-80$ anos AP (Calibrado: de 8450 AC até 8265 AC - Beta 98573). Aqui foram encontrados plano-convexos e muito refugo, tanto de peças unifaciais quanto bifaciais. No entanto, só um fragmento de ponta de projétil foi achado.

Segundo Fogaça (2002) seria possível agrupar a coleção lítica dos níveis mais antigos da Lapa do Boquête em dois grandes conjuntos distintos (fases):

- dos níveis VIII ao VI (12000 - 8000 AP) foram recuperados instrumentos retocados unifacialmente (associados, entretanto, no nível mais antigo a dejetos de talhe de peças foliáceas e a um fragmento de ponta de projétil).

- A partir de nível V (sem datações) desaparecem na área escavada os instrumentos retocados (bem como os nucleos), havendo ocorrência de novas variedades de sílex.

A principal indústria pré-cerâmica descrita, encontrada nas camadas mais profundas da Lapa do Boquête (FOGAÇA, 2002), está relacionada à indústria característica do Brasil Central, do final do pleistoceno e início do holoceno, entre cerca 11000 e 9000 AP, que é conhecida como Tradição Itaparica. Ela foi pela primeira vez descrita por Calderón na década de 1960 no âmbito do PRONAPA, a partir de vestígios encontrados na Gruta do Padre, localizado no vale do rio São Francisco, no estado de Pernambuco. Nas décadas seguintes a mesma tecnologia foi identificada nos estados de Minas Gerais, Goiás, Bahia, São Paulo, Mato Grosso, Piauí e Tocantins (BUENO, 2005).

As camadas inferiores (VIII e X) da Lapa do Dragão, no vale do rio Cochá, foram datadas entre 10.000+/-255 anos (CDTN 1007) e 11000+/-300 anos AP (CDTN 1008). A indústria é composta principalmente de chert e arenito, mas também inclui espessos instrumentos de quartzito retocados unifacialmente. Pequenas e médias lascas finas de chert e calcedônia são típicas do talhe e retoque de artefatos delicados. Muitos deles apresentam coloração avermelhada por causa de acidentes térmicos. Nenhuma estrutura de combustão foi encontrada nas camadas mais antigas, portanto as datações foram obtidas de carvões esparsos.

Quando confrontado com os vestígios líticos dos níveis mais recentes (do arcaico médio e recente), percebeu-se uma redução quantitativa de peças retocadas, se comparada com o período anterior. 
Este "desaparecimento" da técnica de retoque durante o holoceno médio e superior [recente] foi também notado nos abrigos de Goiás estudados por Schmitz e outros, durante sua fase Serranópolis, e nas escavações de O.Dias em Unaí (MG). No entanto, parece ter havido alguns componentes arqueológicos com material retocado em sítios isolados; é o caso na Lapa Pequena escavada por Alan Bryan, e também da Lapa do Dragão (Montalvânia) onde um nível datado de 5000 BP apresenta uma indústria original sobre arenito metamorfizado, com lascas grandes e espessas mostrando retoque unifacial e por vezes alterno (PROUS, 1983-1984:56).

Os sítios dos vales dos rios Peruaçu e Cochá, no norte de Minas, apresentam uma indústria lítica que mais se encaixa, em termos cronológicos e tecno-tipológicos, no quadro regional do Brasil Central. Esse padrão também foi reconhecido no Triângulo Mineiro e no noroeste do estado de Minas Gerais (PROUS, 1992).

Novidades tecnológicas como retoque bifacial para pontas de projétil e o polimento para machados, aparecem muito cedo no centro do estado (Lagoa Santa, Serra do Cipó) mas são ausentes da seqüência arqueológica nos abrigos do Norte do estado (PROUS, 1983-1984).

A região de Lagoa Santa, por outro lado, apresenta uma indústria diferenciada com instrumentos bifaciais mais presentes, além de um intenso lascamento bipolar sobre quartzo e a presença, ainda no arcaico, de machadinhas parcialmente polidas. Na Serra do Espinhaço existe, além do lascamento bipolar sobre quartzo, uma indústria de raspadores sobre plaquetas de quartzito.

\section{2 - Região Sul do Brasil}

$\mathrm{Na}$ região Sul do país as pesquisas, sob orientação pronapiana, deram origem às tradições pré-cerâmicas Umbu e Humaitá. A distinção entre ambas estabeleceu-se através da presença de artefatos líticos diagnósticos, sendo a tradição Umbu caracterizada por possuir pontas de projétil líticas (DIAS, 1994:46). Essa tradição aparece sobre uma grande extensão territorial e estaria associada à exploração de áreas com vegetação aberta, em contraste com a tradição Humaitá cujas ferramentas líticas, mais robustas, estariam ligadas à exploração de áreas de mata. As pontas de projétil associadas à tradição Umbu são encontradas no sul e sudeste do país entre cerca de 8 a 1 mil anos AP. A tecnologia de fabricação de pontas bifaciais é conhecida tanto no sul quanto no Brasil central, no entanto, no sul as pontas aprecem em grandes quantidades nos abrigos ao contrário do Brasil central. 
Tendo em vista a indústria de pontas de projétil encontrada na Gruta do Marinheiro foi optado por uma caracterização apenas da tradição Umbu. As evidências dessa indústria, ao contrário da tradição Itaparica ${ }^{21}$, descrita no item anterior, aparecem ao longo de praticamente todo período arcaico e se concentram na porção Sul do país. Seus traços mais setentrionais extrapolam o limite dos estados sulinos e foram encontrados no estado de São Paulo, em sítios da bacia do rio Tietê e no vale do Ribeira.

No município de Rio Claro (SP), o sítio Alice Boër revelou níveis do arcaico antigo com pontas pedunculadas com aletas, além de plano-convexos e bifaces foliáceos (CALDARELLI, 1983). O sítio Nova Esperança, localizado no vale do Tietê, município de Pereiras, apresenta uma grande extensão e uma abundância de material lítico em superfície, comportando, além de raspadores, lascas e núcleos, também pontas bifaciais de sílex (CALDARELLI \& NEVES, 198182:94).

[..] os sítios do vale do rio Tietê apresentam uma grande maioria de artefatos sobre lascas ou blocos com retoques marginais, lembrando os artefatos da tradição Umbu. Pontas de projétil bifaciais foram registradas em alguns dos sítios (CALDARELLI \& NEVES, 1981-82: 98).

As evidências que caracterizam a tradição Umbu não se limitam apenas a tipos de ferramentas. Na bacia do Ribeira (SP), o sítio Capelinha apresentou uma reocupação no arcaico antigo de um sambaqui fluvial por caçadores-coletores dessa tradição (LIMA, 2005:104). As características (LIMA, 2005: 15-16), além da preponderância da ponta de projétil sobre os demais instrumentos, foram a grande quantidade de resíduos ligados à produção desse tipo de artefato e a distribuição dos vestígios sobre todos os níveis do pacote antrópico referente a essa cultura arqueológica. Em contraste com outros sítios dessa tradição, o sítio Capelinha não apresentou uma grande variedade de raspadores unifaciais. Trataria-se talvez de um sítio para realizar atividades específicas em vez de uma unidade residencial (esse com uma maior diversidade de artefatos).

Para a caracterização da indústria Umbu pelo PRONAPA foi estabelecida uma seriação baseada na morfologia das pontas de projétil líticas, na tentativa de colocar os diferentes tipos morfológicos como marcadores espaço-temporais (DIAS, 1994:47). Conclui-se que a variação na morfologia pode talvez indicar uma preferência temporal, mas parece apontar mais para uma permanência cultural ao longo de milhares de anos do que para mudanças.

\footnotetext{
${ }^{21}$ Restrita ao arcaico antigo.
} 


\section{CAPÍTULO 3 - A ÁREA DE PESQUISA}

\section{1 - Localização e Delimitação}

A Província Cárstica do Alto São Francisco situa-se no centro-oeste do estado de Minas Gerais e é constituída por uma extensa área cárstica, com cerca $1500 \mathrm{~km}^{2}$. A região, inserida no alto curso do rio São Francisco, faz limite (ao sul) com a bacia do rio Grande, um dos principais formadores do rio Paraná. A localização da Província nas proximidades de dois grandes cursos d'água, os rios Grande e São Francisco, torna a região suscetível a influências oriundas tanto do centro e norte mineiro e nordeste brasileiro, através da bacia do rio São Francisco, quanto do sul do país, através da bacia do rio Paraná (levando em consideração que os cursos navegáveis formavam as principais vias naturais de comunicação na pré-história).

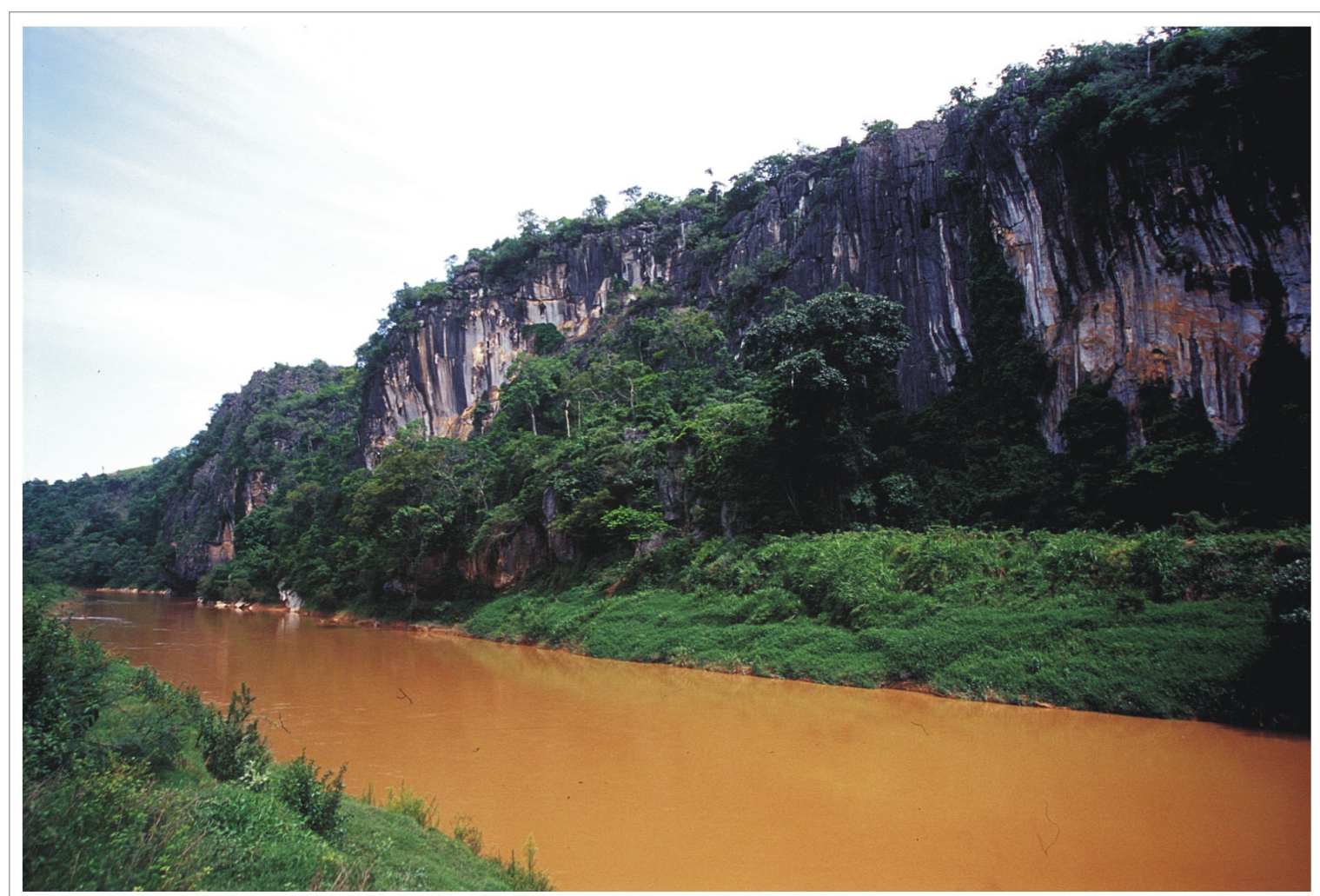

FOTO do Rio São Francisco recortando os afloramentos de calcário entre os municípios de Bambuí e Doresópolis, na porção Oeste (W) da Província (Cyro Soares).

A $70 \mathrm{Km}(\mathrm{E})$ da nascente do rio São Francisco no Parque Nacional da Serra da Canastra, a área compreende a totalidade dos municípios de Doresópolis e Pains, e partes dos municípios de Arcos, Bambuí, Córrego Fundo, Formiga, Iguatama, Pimenta e Piumhí. A área de estudo apresenta uma alta concentração de afloramentos calcários, principalmente ao longo das micro-bacias do ribeirão dos Patos e do rio São Miguel, que recortam a região. Ambos são 
afluentes da margem direita do rio São Francisco e apresentam um sistema de drenagem tanto subterrâneo quanto superficial. Apesar de ser uma região cárstica, que tem como principal característica uma drenagem de sentido predominantemente vertical e subterrânea, seguindo fendas, condutos e cavernas, isso não resultou na completa ausência de cursos de água superficiais no período da estiagem (de abril a outubro).

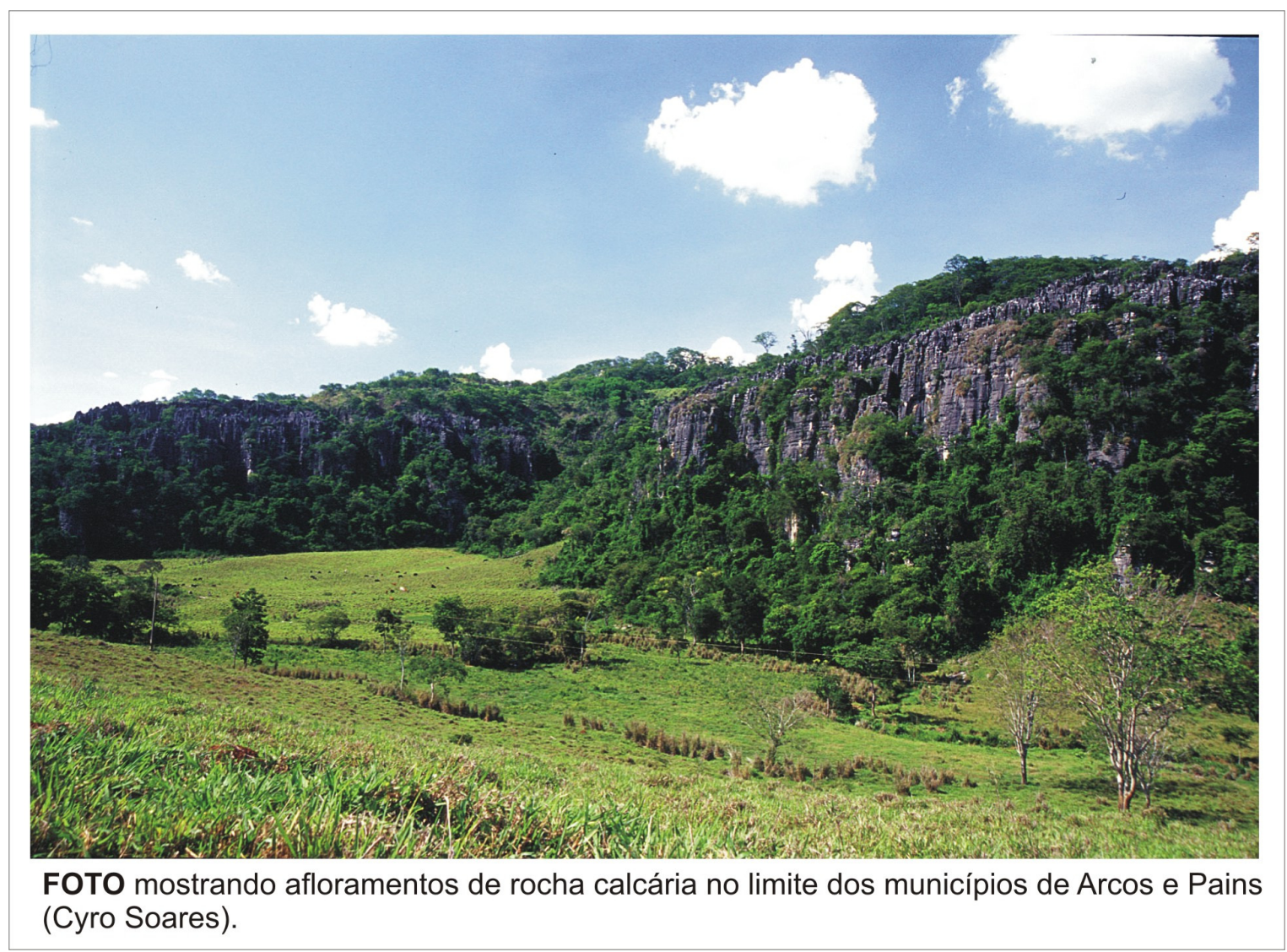

A região se destaca do seu entorno por ser, comparativamente, uma área de difícil penetração, constituída originalmente por espessas matas que, apesar de estarem localizadas em região de cerrado, apresentam elementos da caatinga e da mata atlântica. Acredita-se que a mata original, os paredões de calcário, os córregos e ribeirões, e os brejos e as lagoas formavam um conjunto labiríntico e cheio de obstáculos. De tal maneira que a região foi contornada, desde o século XVIII, pelas principais vias de comunicação estabelecidas entre o centro e o oeste de Minas (ver mapa abaixo). Esses caminhos foram utilizados, no século passado, para a implantação de rodovias asfaltadas que representam atualmente, aproximadamente, os limites sul, leste e nordeste da província. O limite oeste corresponde ao traçado do rio São Francisco, onde os afloramentos de calcário formam um canyon profundo ao 
longo de vários quilômetros; o limite sul também corresponde ao divisor de águas com a bacia do rio Grande, com a sudoeste a serra da Pimenta $\left(1200 \mathrm{~m} \mathrm{anm}^{22}\right)$ que se destaca na paisagem.

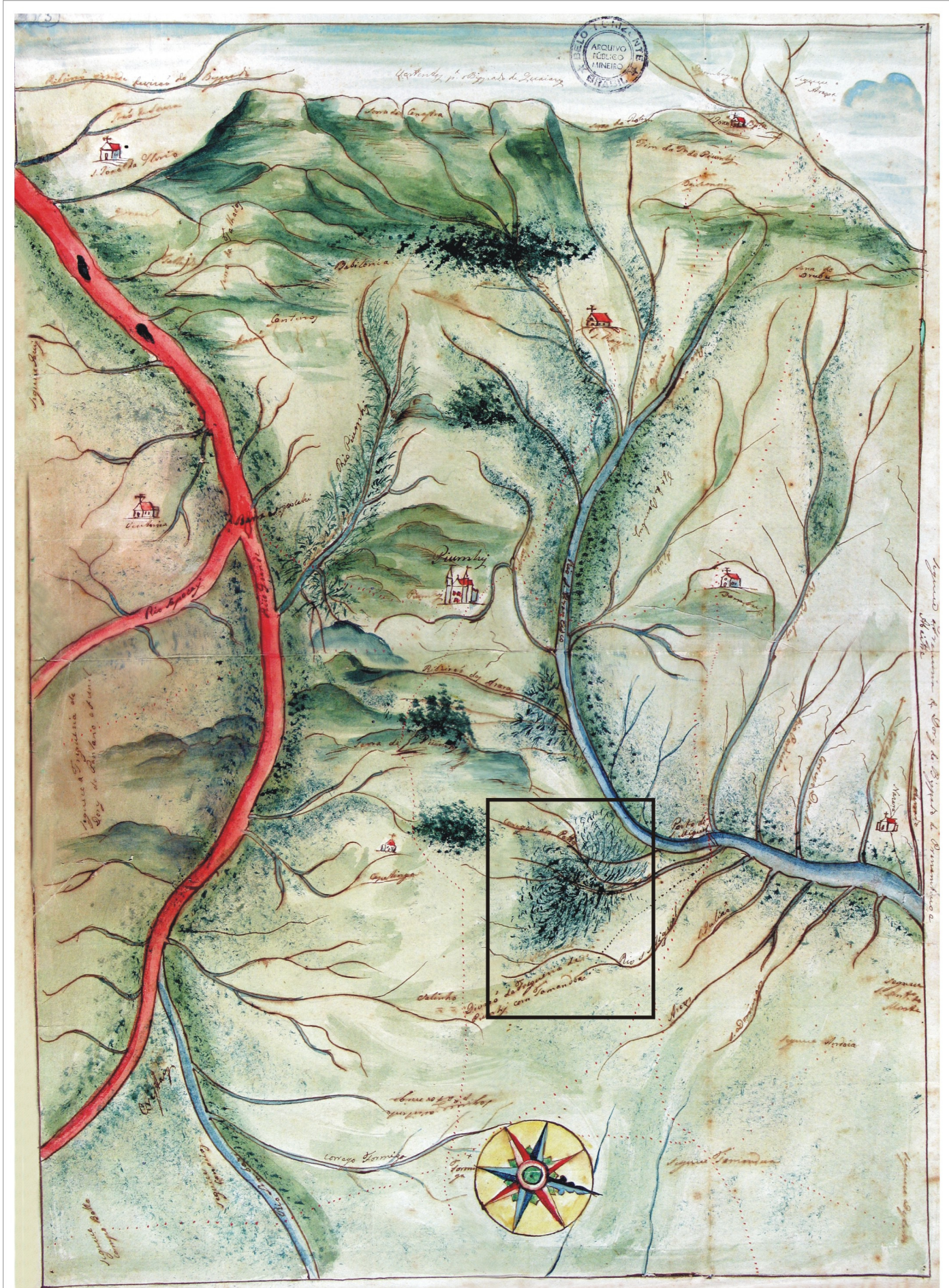

Reprodução de mapa, orientado para Oeste (W) e provavelmente do final do século XVIII ou início do XIX, mostrando o encontro das bacias do Rio Grande (em vermelho) e do Rio São Francisco (em azul), com o perfil da Serra da Canastra no fundo. A região onde a presente pesquisa foi desenvolvida está destacada com um retângulo (FONTE: Arquivo Público Mineiro).

${ }^{22}$ Acima do nível do mar. 


\section{2 - Relevo e Geologia}

A região está inserida na porção sudoeste de um extenso núcleo cratônico, o Cráton do São Francisco, estabilizado no fim do ciclo transamazônico. A superfície dessa área foi encoberta por depósitos sedimentares provenientes da erosão e decomposição de rochas adjacentes e por deposição de sedimentos no fundo de um mar extenso que encobria a região.

During an important glaciation in the beginning of the Late Proterozoic Era, a shallow epicontinental sea was formed and extended over most of Central Brazil, including the Rio São Francisco Valley. Sedimentary deposits formed at the sea bottom originated from erosion and decomposition of adjacent Precambrian rocks. Those deposits are represented by tillite and other correlates, initiating the sedimentation of the "Bambuí Group" (limestone), which is present in the states of Minas Gerais, Bahia, Goiás and Mato Grosso. During the Silurian Period, the sea disappeared and the deposits hardened, forming the limestone stratum known as the "Bambuí Formation" (KIPNIS, 2002:58)

Na Província os calcários pertencem à Formação Sete Lagoas do Grupo Bambuí e são representados localmente por seqüências de calcários calcíticos, dolomíticos, estromatolíticos, margas e intercalações subordinadas de metapelitos.

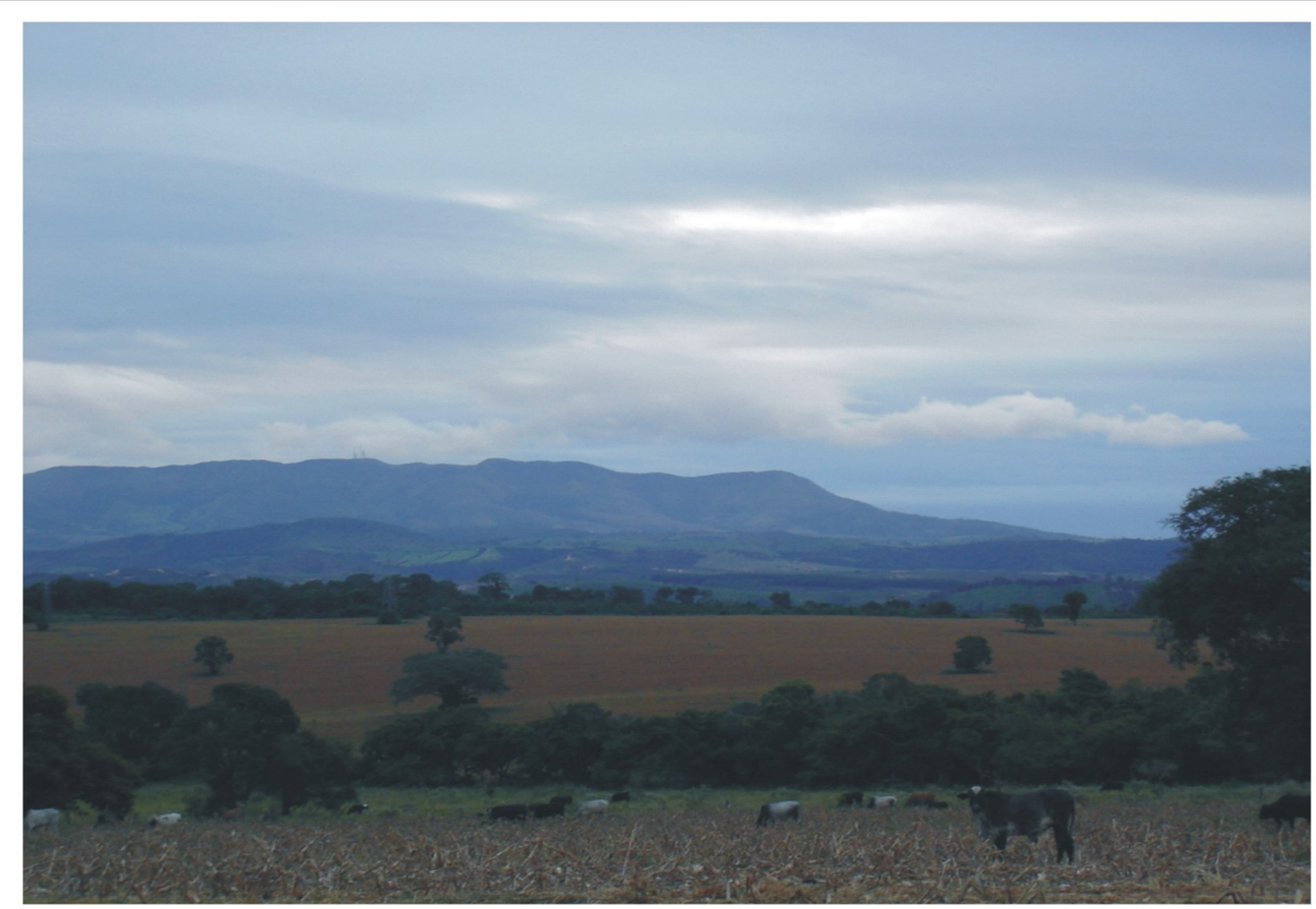

FOTO com vista parcial da Serra da Pimenta a partir da porção sudoeste do município de Pains. 
A Província é circundada por duas outras formações: rochas do Complexo GnaisseMigmatítico Campo Belo, de provável idade arqueana, limitam a região a sul e leste (município de Formiga), enquanto a sudoeste (municípios de Pimenta e Piumhí) ocorrem faixas de dobramentos proterozóicos com seqüências metassedimentares, sobretudo conglomerados, quartzitos e filitos do Supergrupo Canastra, representados pelas Serra da Pimenta (ver foto acima) e Morro do Diamante.

A gênese e evolução do carste dependem de numerosos fatores, entre eles litologia, estratigrafia, tectônica, paleoclima, clima atual e recobrimento florístico. Este conjunto de fatores condicionam a maior ou menor expressão das formas cársticas numa determinada região.

O relevo cárstico deve possuir certa escala, isto é, ter uma determinada extensão regional para que feições não sejam apenas isoladas e insuficientes para a caracterização da assembléia morfológica típica de um verdadeiro carste. O relevo cárstico compreende feições topográficas características originadas pela dissolução de rochas calcárias. Constitui uma modalidade associativa de formas vinculadas à presença de grandes massas de rochas calcárias, principalmente daquelas mais puras e que, em geral, estão sujeitas a processos combinados de dissolução química e erosão mecânica. O balanço da atuação entre este ou aquele processo demonstra uma participação variada e relativa, tanto no tempo quanto no espaço, ao originar as diferentes formas de associação na gênese habitual dos componentes do relevo cárstico.

Na Província foram registradas mais de 450 cavidades significativas, sendo que algumas delas com desenvolvimento superior a 300 metros, destacando-se a Gruta do Éden (1,6 Km) e o sistema Brega-Santuário, com pouco mais de $2 \mathrm{Km}$ de extensão (PIZARRO, FRIGO \& CAMPELO, 2001). Muitas dessas cavidades apresentam vestígios de ocupações pré-históricas. O calcário preserva melhor os vestígios por causa do ambiente básico, permitindo uma maior durabilidade dos artefatos, inclusive orgânicos. 


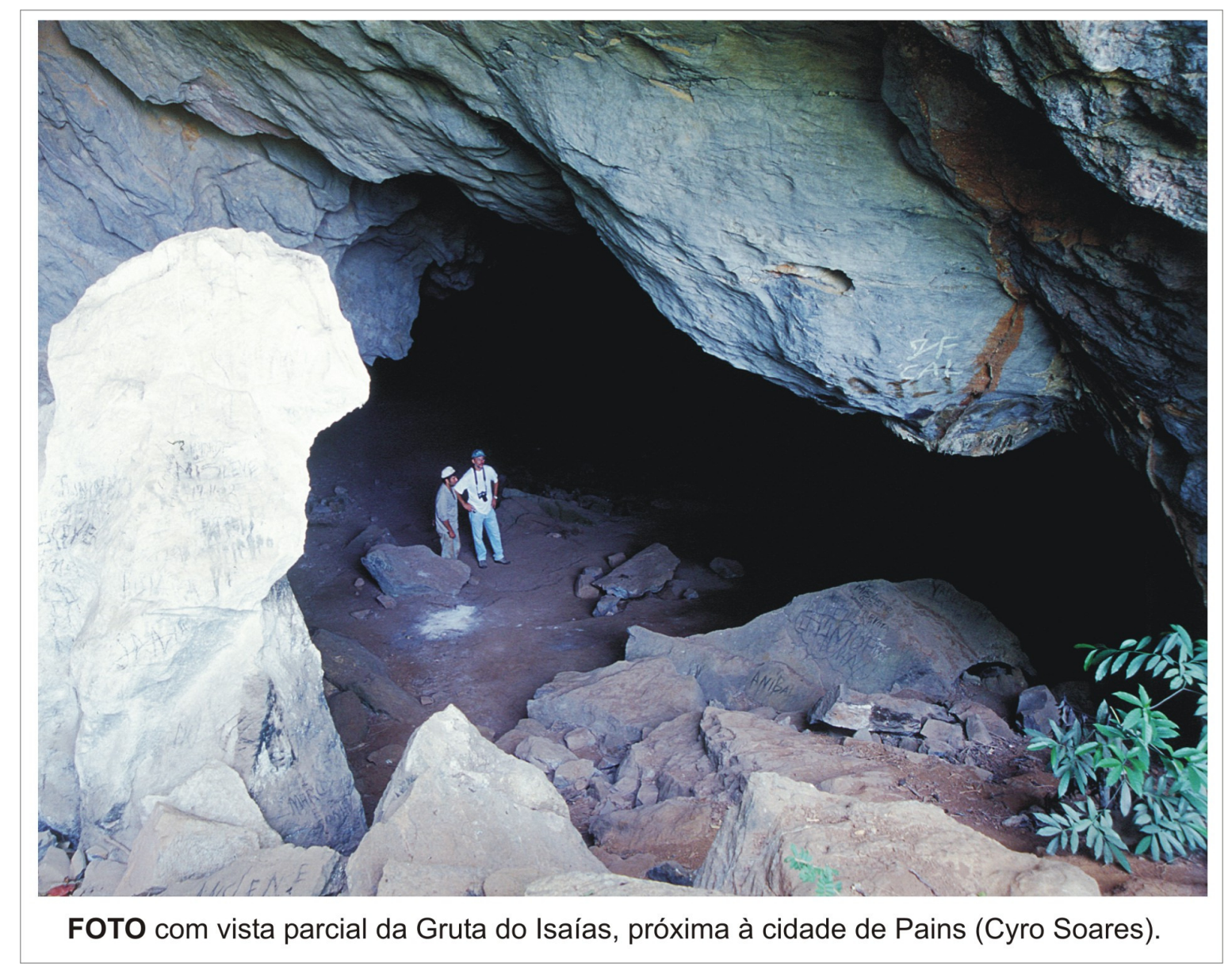

Uma compartimentalização geológico-geomorfológica subdividiu a Província em quatro blocos cortados pelos principais cursos d'água (PIZARRO, 1998).

1ํ - São Miguel: no extremo leste, é o maior, mais contínuo, menos deformado e com grande incidência de cavidades naturais.

2o - Intermediário: estende-se por uma faixa N/S e foi dividido em dois domínios:

a) Centro-Sul: com lentes de calcário esparsas em rochas pelíticas.

b) Norte: com conjuntos de maciços contínuos, deformados tectônicamente.

3 - Ribeirão dos Patos: a oeste, apresenta duas faixas de maciços contínuos de direção NW/SE e um corredor entre ambos composto de rochas pelíticas. Os três principais sítios abordados na presente dissertação - Gruta do Marinheiro, Loca do Suim e Abrigo da Lagoa de Peixe I - situam-se nesse bloco. 
4ํ- São Francisco: no extremo oeste, comporta a Faixa do Cânion de calcário contínuo e deformado, com maciços isolados na margem esquerda do rio São Francisco.

A paisagem cárstica se destaca da monotonia das margens do rio São Francisco pelas feições morfológicas desenvolvidas sobre as rochas carbonáticas, de acordo com Alacrino Monteiro, engenheiro do Serviço Geográfico de Minas Gerais, que visitou a região em 1931:

[..] merecem menção os aspectos bizarros e muitíssimo interessantes oferecidos pelas gigantescas serras constituídas de rochas calcáreas. Umas se apresentam a nossa visão como que verdadeiros castelos da época medieval. Outras exibem interessantes minaretes, ou então caprichosas cimalhas de casa, quando não tomam as formas de torres, arquitraves, frontispícios de igrejas, nichos, etc. Algumas dessas serras, quando vistas de longe, dão-nos a impressão de grandes batalhões de cossacos, ao passo que, divisadas de certos pontos, mostram as figuras de monges em meditação ou de freiras em penitencia, assim como desenhos sugestivos e fantásticos, fazendo-nos recordar as esculturas que adornam as paredes dos antigos templos egípcios e, de outras vezes, as figuras singulares de estranhas mitologias.

O carste possui características peculiares com paredões, torres, mesetas, verrugas, lapiás, dolinas, uvalas, poliés, vales cegos, drenagem subterrânea, abismos, cavernas e os abrigos com seus sumidouros frente a lagoas de águas cristalinas sempre atraíram o homem desde os seus primórdios (KOHLER, 1989).

A água age tanto na dissolução da rocha, formando condutos e galerias, quanto no aporte e deposição de sedimento. Neste contexto, informações externas que eventualmente sejam 'capturadas' por uma caverna podem conservar-se por longo tempo, constituindo registros importantes sobre o passado de uma dada região. As cavernas do Grupo Bambuí são especialmente importantes no que diz respeito à fauna do período pleistocênico. Em 1998 foi retirado na Gruta do Angá, município de Pains, um dos mais completos crânios de mastodonte já encontrados no Brasil.

O potencial arqueológico do carste, notadamente dos depósitos sedimentares das cavernas e dos abrigos, decorre de pelo menos dois fatores: a baixa intensidade de processos erosivos, já que nas áreas abrigadas a ação das águas das chuvas é praticamente nula. E a presença da calcita, que é um mineral proveniente da dissolução e precipitação das rochas carbonáticas e funciona como uma lápide petrificada sobre esses depósitos, fossilizando-se e preservando os vestígios arqueológicos, especialmente os de natureza orgânica, por longo tempo (KOHLER 1989).

No caso da Província Cárstica as primeiras evidencias arqueológicas e paleontológicas foram notadas por Eschwege, quando visitou algumas cavernas na região em 1816, quase uma década antes de Lund chegar à região de Lagoa Santa. 
Vou finalmente fazer menção dos ossos fosseis, encontrados, as vezes, no conglomerado da caverna. Os que vi consistiam em fragmentos parecendo pertencer ao tíbia do veado. Além dos fosseis se encontram dispersos no fundo da caverna um grande numero de outros ossos, estando estes inteiramente conservados e pertencendo provavelmente a animais que ali se refugiaram ou devoraram as suas presas. Crânios e ossos humanos foram também encontrados nessa caverna, e pertencem provavelmente a infelizes ou a índios que ali pousaram (ESCHWEGE, 1979).

Em 1881 Francisco de Paula publicou nos Anais da Escola de Minas de Ouro Preto (vol. 1) um relatório sobre a região.

Nas margens do Rio São Francisco, notam-se grandes camadas de calcário que tem uma extensão considerável. Nessas camadas, as águas cavaram profundas e compridas grutas que foram depois cheias de uma terra argilosa e de limo. São as grutas de salitre onde o Dr. Lund tem feito estudos paleontológicos importantes e retirando grande numero de fosseis. Além de muitas outras, existem duas importantes nas vizinhanças do arraial de Arcos a quatro e meia léguas ao oeste da cidade de Formiga.

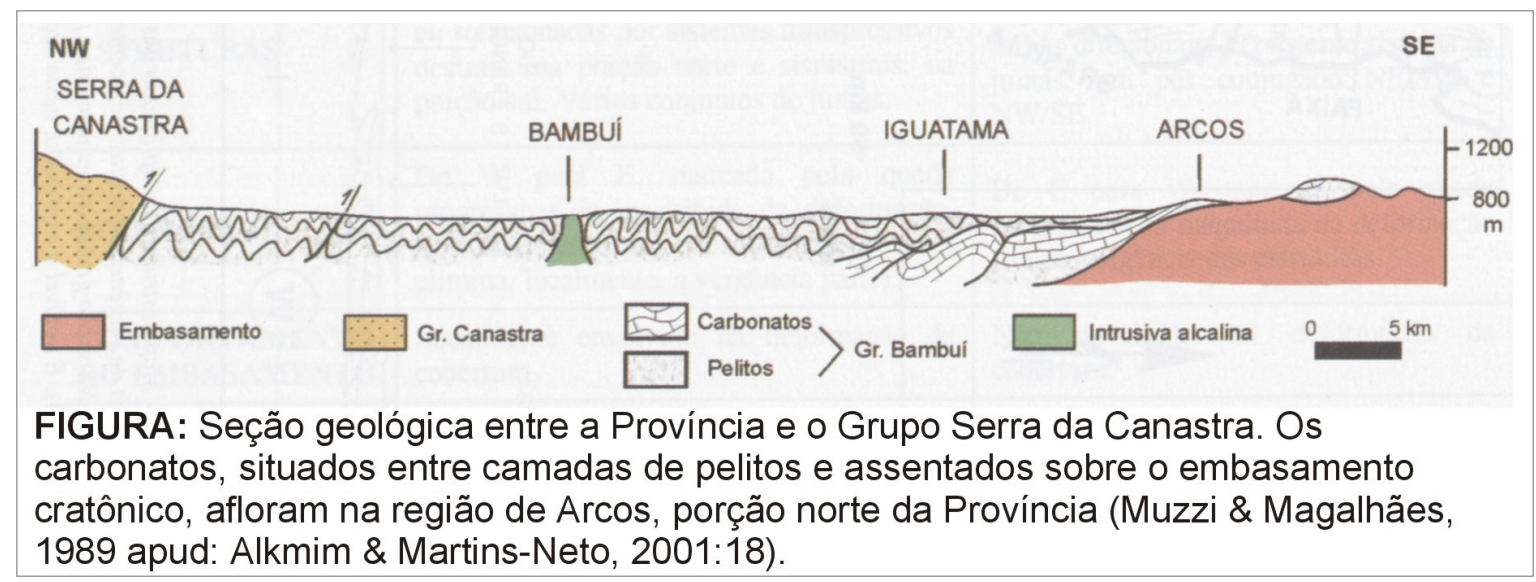

\section{3 - Hidrografia}

A Província Cárstica é recortada pelo rio São Miguel e pelo ribeirão dos Patos, ambos tributários do rio São Francisco.

A bacia do rio São Miguel, entre os paralelos 20¹0' e 20ํำ' de latitude sul e os meridianos de 45 $30^{\prime}$ e 4545' de longitude oeste, tem área de aproximadamente 500 km². O curso principal possui direção geral $\mathrm{S} / \mathrm{N}$ por cerca de $40 \mathrm{~km}$. O seu padrão morfológico é meandrante até sua confluência com o rio São Francisco. Os principais afluentes da margem oeste, de montante para a jusante, são: ribeirão das Moendas, córrego da Mina, córrego do Mandengo e córrego do Fundão. Na margem leste são: córrego da Barra (cuja confluência com 
o ribeirão das Moendas forma o rio São Miguel) e rio Candongas (HADDAD, 2006). O rio São Miguel encontra-se bastante impactado.

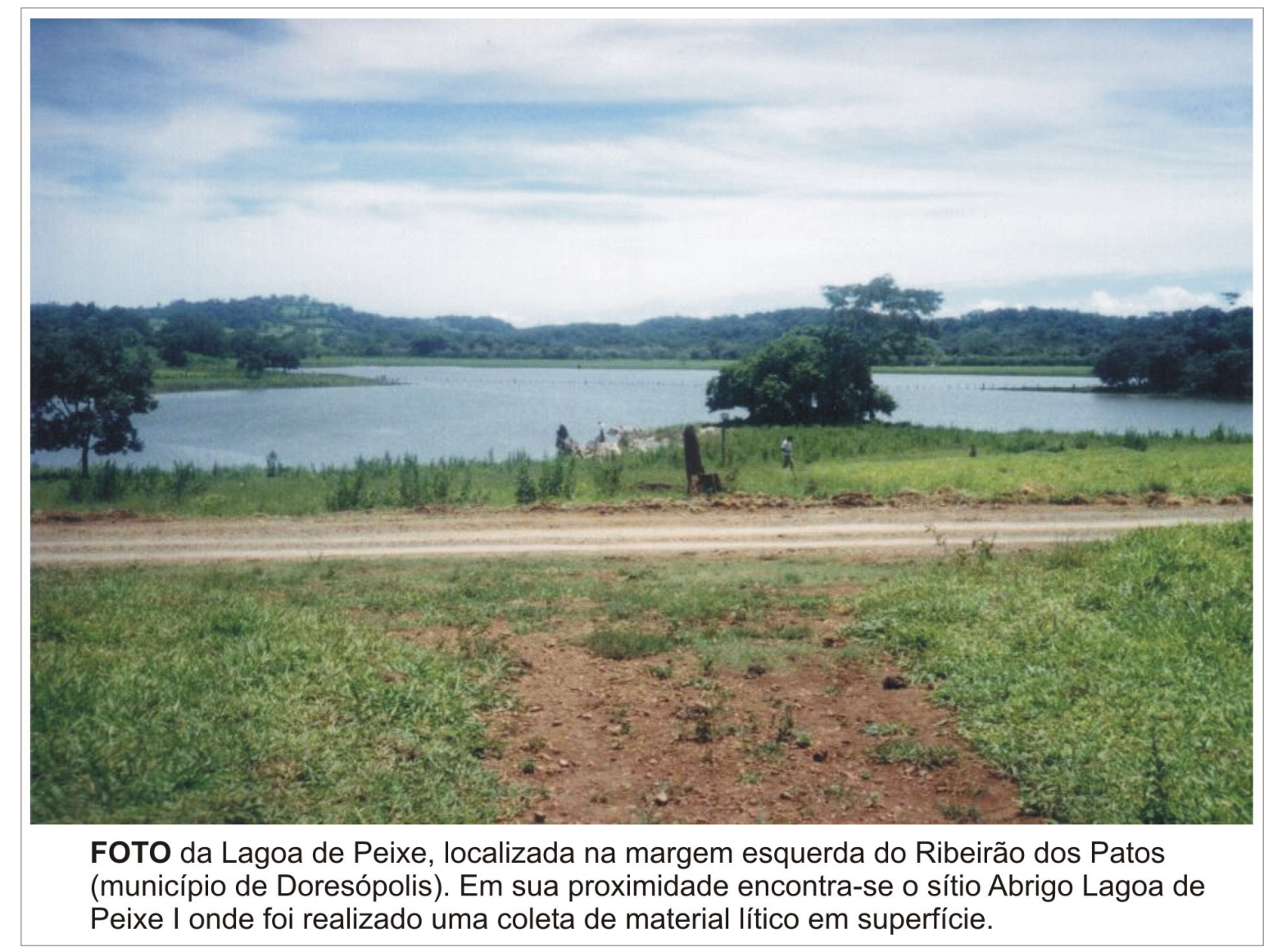

A bacia do ribeirão dos Patos, entre os paralelos $20^{\circ} 12^{\prime}$ e $20^{\circ} 27^{\prime}$ de latitude sul e os

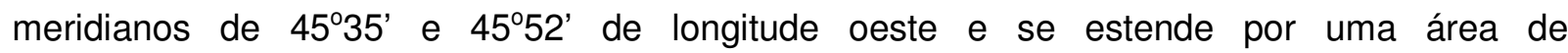
aproximadamente $550 \mathrm{~km}^{2}$. Assim como o São Miguel apresenta orientação geral S/N, especialmente na sua barra com o rio São Francisco. Os principais tributários são: os córregos da Matinha, do Cavalo e da Vaca, alem de dezenas de pequenos rios intermitentes, que muitas vezes deságuam no ribeirão dos Patos através de drenagens de subsuperfície.

Mas a principal característica do sistema hídrico regional é a sua relação com o relevo, já que a água é a grande responsável pela fisionomia peculiar das áreas cársticas. $\mathrm{A}$ ação hídrica, dissolvendo o carbonato e escavando a rocha bruta, transformando um cenário monótono em uma região repleta de formas únicas com lagoas, sumidouros, surgências e ressurgências. Além disso, a água penetra nas fendas do calcário e cria no interior das cavernas esculturas carbonáticas (espeleotemas) de composição e forma únicas. 
Os espeleotemas formados pelas águas circulantes originam-se da deposição do CaCO3, contido em soluções aquosas que se movem no carste subterrâneo, principalmente pela ação da gravidade...e de dois mecanismos básicos de deposição: gotejamento e escorrimento. Os espeleotemas ocorrem tanto no teto, como nas paredes e no piso das cavernas (BIGARELLA, BECKER \& SANTOS, 1994: 293).

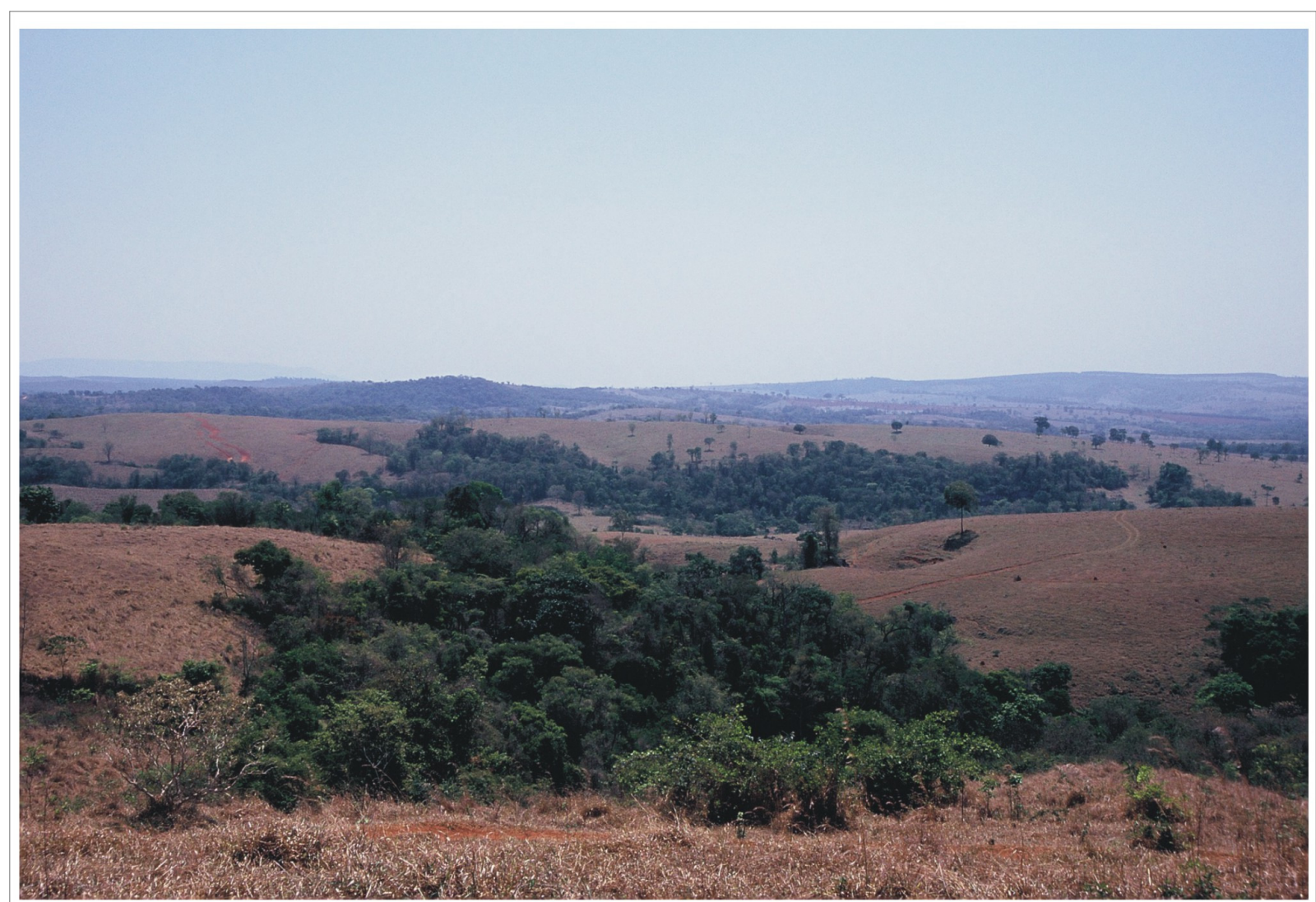

FOTO com visão parcial do planalto de dolinas na porção sul da Província, região onde nascem o Ribeirão dos Patos e o Rio São Miguel. A vegetação na foto encobre dolinas e uvalas (foto Cyro Soares).

Parte desse processo ocorre em subsuperfície, em locais de difícil acesso. Tanto na bacia do São Miguel, quanto na do ribeirão dos Patos é possível observar nos rios principais e em muitos afluentes a ocorrência de sumidouros, surgências e ressurgências. No córrego Barreado, por exemplo, num trecho de aproximadamente $10 \mathrm{~km}$, antes da sua confluência com o ribeirão dos Patos, foram identificados oito sumidouros, com suas respectivas ressurgências, todos relacionados a cavernas em formação.

A ação subterrânea das águas da Província foi notada e anotada por Alacrino Monteiro:

Em Pains e suas vizinhanças as águas, além de fortemente salobras, são subterrâneas, existindo verdadeiros cursos d'água a alguns metros de profundidade. 
Consegui verificar que essas águas estão em contínuo movimento, isto é, que são córregos subterrâneos e não simples lençóis d'água, como é muito comum em algumas localidades.

Logrei também determinar a direção das águas subterrâneas, verificando que iam ter a regatos e rios da superfície.

Além dessas águas subterrâneas é digno de nota e constitui um caso interessante o grande número de poços existentes nessa região, uns já formados e outros em formação. Encontrei também um grande número de enormes e lindas lagoas de água salgada, as quais suponho, devem estar, igualmente, em comunicação com os cursos subterrâneos, pois não há vestígios de nascente e nem se sabe para onde correm suas águas. Dessas lagoas podem-se citar a do Córrego Fundo, a dos Campos, a da Caveira e como a maior e mais interessante, a Lagoa do Retiro (ALACRINO MONTEIRO, 1931).

\section{4 - Vegetação}

Os recursos vegetais eram uma importante parte da economia das sociedades de caçadores-coletores, já que as plantas são úteis não apenas na alimentação, mas em diferentes finalidades: uso medicinal, pigmentos para tintas, recipientes para transporte de líquidos; madeira para construções variadas; palhas e fibras para cordas e trançados.

A principal característica da vegetação da região é a ocorrência de dois tipos de cobertura vegetal bastante diferenciadas em regiões relativamente próximas: o Cerrado (Savana) que circunda toda a região e a formação Florestal Montana, ou Mata de Seca, que domina o centro da Província, especialmente as regiões com afloramentos rochosos.

A região do Cerrado apresenta um período seco de aproximadamente seis meses e é dominada por uma vegetação de formação campestre do Cerrado Gramíneo Lenhoso com floresta galeria, que apresenta como elemento característico a Araucaria angustifólia. E manchas de Cerrado Arbóreo Aberto, com fanerófitas de tronco rugoso, copas esgalhadas e altura de 5 a $15 \mathrm{~m}$, além de caméfitas, lenhosas, cespitosas providas de xilopódios e tapetes de hemicriptóficas (HADDAD, 2006).

No carste o sistema de drenagem, com presença de sumidouros e circulação de água subterrânea, acentua o baixo teor de água que percola no solo e imprime caráter estacional, representado por pequenos agrupamentos de Mata Seca (HADDAD, 2006). Ela se localiza em altitudes entre 500 e 800 m revestindo os terrenos calcários. Durante a estação chuvosa a Mata Seca assume uma fisionomia exuberante, as árvores de grande porte apresentam variados tons de verde, enquanto as flores, especialmente as orquídeas e bromélias, decoram os paredões rochosos com uma infinidade de cores. À medida que as chuvas diminuem e o inverno se aproxima a ausência de água transforma gradativamente o verde da mata em tons desbotados e secos de amarelo, vermelho e marrom. As espécies que mais caracterizam o estrato arbóreo são: Angico (Piptadenia sp.), Jequitibá Rosa (Cariniana sp.), Pau d'Óleo ou Copaíba (Copaífera 
sp.), Aroeira (Astronium sp.), Angico Vermelho (Parapiptadenia rígida) e Canelas (Ocotea sp. e Nectandra sp.) (BRASIL, 1983).

Para o norte as colinas achatam-se completamente em extensas planuras; as rochas desaparecem e profunda camada de terra vegetal cobre o solo dos tristes campos que atravessamos. Dentre as ervas destes campos, surgem enfezadas árvores de 2 metros de altura, mas viam-se, de ambos os lados, a alguma distância, matas de altos troncos, que se estendem por quatro léguas e terminam no Rio São Miguel. Sobre uma ponte de madeira atravessamos este rio, que corre de sudeste para noroeste, e depois do pôr do sol atingimos a Fazenda de Dona Bernarda, onde outra vez nos alojamos num paiol de milho (POHL, 1976:92).

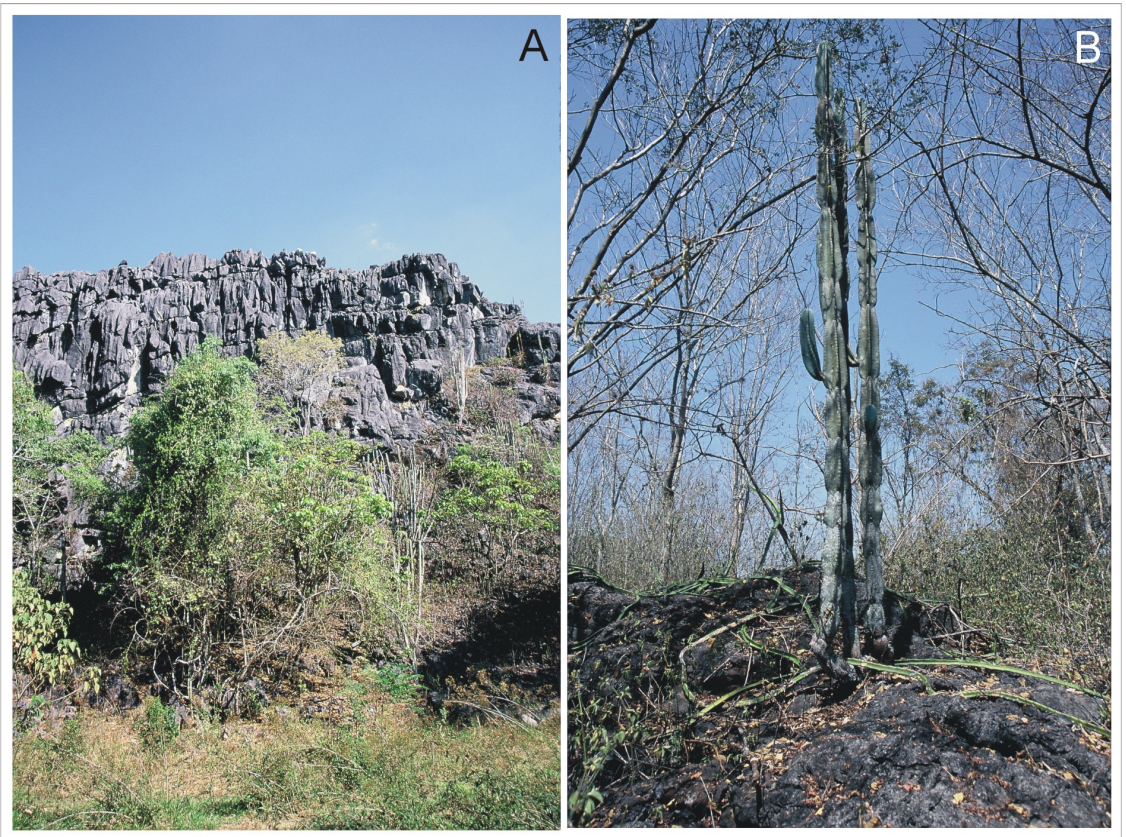

FOTO A: vista de topo de maciço de calcário. FOTO B: vegetação que cresce em cima do calcário (mata seca e cáctus Mandacarú).

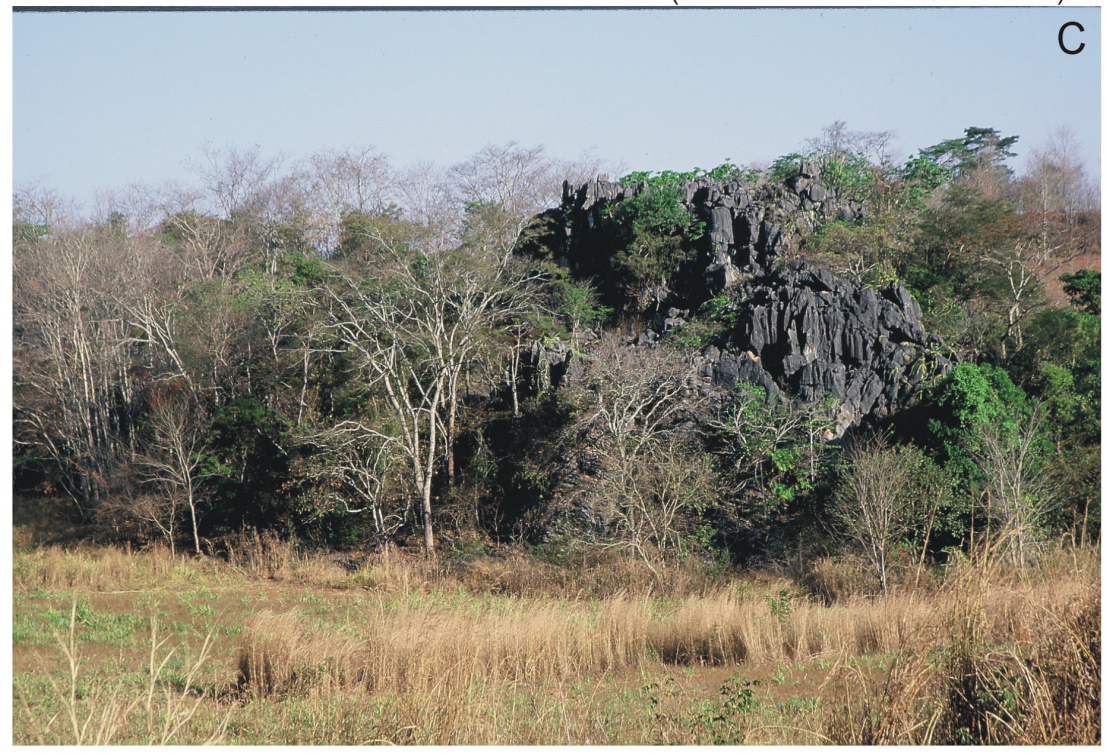

FOTO C: mata seca em torno de afloramento de rocha calcária. 


\section{5 - Fauna}

A atividade agropecuária e mineraria vêm impondo profundas modificações na paisagem da Província Cárstica. Nos dias atuais, os moradores da zona rural ainda praticam a caça e a pesca, especialmente no vale do Ribeirão dos Patos, relativamente mais preservado que a região do rio São Miguel. Durante os trabalhos de campo é comum observar espécies de médio porte da fauna local: lobos, tamanduá-bandeira, capivara (Hydrochoerus hydrochoeris), veado, caititu e paca (Cuniculus paca), apesar dos desmatamentos, tão comuns na região.

As atividades relacionadas à exploração econômica das rochas carbonáticas e derivados tiveram inicio na década de 1960 e vêm se intensificando desde então. Hoje alem das empresas de variados portes e origens, que se dedicam ao beneficiamento do calcário, ocorrem ainda "garimpos" clandestinos, grandes responsáveis pela supressão e deterioração do patrimônio espeleológico e arqueológico. Já que tais iniciativas, ao contrario dos empreendimentos legalizados, não contam com qualquer tipo de licença para atividades de mineração, ou acompanhamento dos órgãos ambientais.

\section{6 - Justificativa}

A Província Cárstica do Alto São Francisco é uma das várias regiões dominadas por rochas calcárias inseridas na bacia do rio São Francisco, dentre as quais destacam-se em Minas, o planalto de Lagoa Santa, o vale do rio Peruaçu e o vale do rio Cochá. O grande potencial paleontológico e arqueológico das regiões cársticas tem atraído a atenção de pesquisadores desde o século XIX. A região de Lagoa Santa, por exemplo, foi objeto de escavações ainda em 1835, com Peter Lund. Os trabalhos realizados nessas regiões revelaram vestígios arqueológicos desde o final do Pleistoceno ou início do Holoceno.

Como foi mencionado no Capítulo 3, o potencial arqueológico da região aqui em estudo foi notado no século XIX, pelo pesquisador alemão Wilhelm L. von Eschwege durante visita a algumas cavernas de Formiga, quando observou a ocorrência de restos humanos, inclusive crânios, provavelmente de selvagens que morreram de morte natural (1979:194).

O interesse em realizar pesquisas arqueológicas na Província foi despertado em 1998, a partir da descoberta de um pequeno abrigo no município de Doresópolis, conhecido como Abrigo Lagoa do Peixe I. O sítio apresentava uma grande quantidade de peças lascadas no sedimento erodido, além de uma marcante ausência de cerâmica. O local foi objeto de uma coleta sistemática de superfície e a amostra foi analisada em laboratório. A análise revelou vários elementos tipológicos e tecnológicos em comum com manifestações líticas de caçadores-coletores pré-ceramistas (HENRIQUES, COSTA \& KOOLE, 2001). Notou-se no 
entanto, a partir de bibliografia disponível, que a ocupação desses grupos ainda não havia sido comprovada para a região.

Levantamentos sistemáticos na região haviam sido executados principalmente pelo Instituto de Arqueologia Brasileira - IAB - do Rio de Janeiro, nos anos 1969 e 1970, em função do Programa Nacional de Pesquisas Arqueológicas, o PRONAPA, e nos anos 1970 a 1976 durante o Programa de Pesquisa no Vale do São Francisco, o PROPEVALE. O IAB, sob coordenação do prof. Ondemar Dias Jr., concentrou suas pesquisas no centro (Pains) e no limite oeste do carste (Piumhí e Doresópolis). Os trabalhos resultaram no registro de mais de 40 sítios arqueológicos, entre abrigos, grutas e sítios a céu aberto, principalmente sítios com vestígios cerâmicos e resquícios de fogueiras. Em vários deles foram realizadas coletas de superfície, mas apenas uma cavidade teve uma escavação ampla: o Buracão dos Bichos de Piumhí.

A ocupação da região foi então caracterizada por dois componentes para o período ceramista. O primeiro seria composto por agricultores incipientes, a partir de cerca de dois mil anos, que estariam ligados à tradição Una através de uma expressão local, a fase Pium-hí (DIAS \& CARVALHO, 1981/82). A indústria lítica associada a essa cerâmica, segundo Prous (1992: 338), é conhecida pela presença de lascas de quartzo e calcário e pelo predomínio de artefatos polidos, como machados polidos alongados, mãos de pilão, seixos alisadores, etc. Sítios com vestígios relacionados a essa tradição também são conhecidos no noroeste de Minas, sudeste de Goiás e interior e litoral do estado do Rio de Janeiro.

O segundo momento é marcado pela presença de materiais cerâmicos relacionados à tradição Sapucaí, que corresponderia à chegada de novos grupos de horticultores ceramistas (HENRIQUES Jr., 2006). Os sítios dessa tradição no alto São Francisco apresentam alta densidade de fragmentos cerâmicos de vasilhames piriformes e globulares de variados tamanhos, destacando-se grandes potes para armazenagem de líquidos e grãos e urnas funerárias. O material lítico desses grupos inclui lascas de quartzo não retocadas e lâminas polidas de variadas formas e dimensões, inclusive semi-lunares (PROUS, 1992: 351).

O aparecimento dos grupos ceramistas Una e Aratu-Sapucaí estaria associado a uma nova técnica de transformação da pedra: o polimento. O lascamento por percussão apresentase sob uma forma rudimentar, sem retoques. Esse período caracteriza-se por uma maior ênfase na agricultura, em detrimento da caça, pesca e coleta; com ferramentas de pedra mais pesadas, provavelmente ligadas à derrubada de matas densas, para a instalação de roças do tipo coivara.

Nos anos de 1978 e 1979, o Setor de Arqueologia da Universidade Federal de Minas Gerais desenvolveu levantamentos nos municípios de Arcos e Iguatama, na porção norte do Carste do Alto São Francisco. A área de estudo abrangeu o médio e o baixo curso do rio São 
Miguel, incluindo o local de sua desembocadura na margem direita do rio São Francisco. Foram registrados 24 sítios arqueológicos, compreendendo sítios a céu aberto, grutas e abrigos sob rocha, além de casas subterrâneas. Em alguns sítios arqueológicos os pesquisadores procederam à coleta de material de superfície ou sondagens, obtendo-se uma amostra de material cerâmico. O Setor também registrou alguns sítios rupestres. Entretanto, esse trabalho foi interrompido sem gerar quaisquer dados significativos (PROUS, 1992).

Depois da descoberta do Abrigo Lagoa de Peixe I em 1998, organizou-se etapas de campo com o objetivo de obter uma quantidade significativa de sítios para futuros estudos e para mapear os problemas arqueológicos a serem resolvidos. No primeiro ano os trabalhos aconteceram em parceria com o Instituto de Geociências da Universidade Federal de Minas Gerais, nos anos seguintes sem apoio institucional, mas principalmente em função de consultorias para empresas de mineração de calcário.

O levantamento resultou na descoberta de 118 novos sítios arqueológicos, dos quais 42 sob abrigo, 37 em caverna e 39 a céu aberto. Além disso, foram localizadas 31 ocorrências líticas, ou seja, peças encontradas isoladamente fora do contexto de um sítio. Em termos espaciais, os sítios e ocorrências levantados se encontram distribuídos sobre uma extensa área do carste, desde o canyon do rio São Francisco, a oeste, até o limite dos afloramentos calcários a leste, próximo aos córregos Candongas e Fundão; e de Calciolândia, ao norte, até o planalto de dolinas, ao sul, onde se encontram também as cabeceiras do ribeirão dos Patos e do rio São Miguel. Dentro do carste a densidade de sítios é maior em três áreas em função de levantamentos mais intensivos de superfície. Essas regiões são Mata das Frutas e Barreado, na bacia do Ribeirão dos Patos e Quenta-Sol, na bacia do São Miguel. Apesar de que muitos sítios sob abrigo e em caverna provavelmente desapareceram por causa de atividades minerárias, intensificada nos últimos anos, o impacto não foi completo, restando na região ainda inúmeros maciços calcários com potencial. Os sítios a céu aberto, por outro lado, foram bastante impactados por causa de atividades agro-pastoris generalizadas.

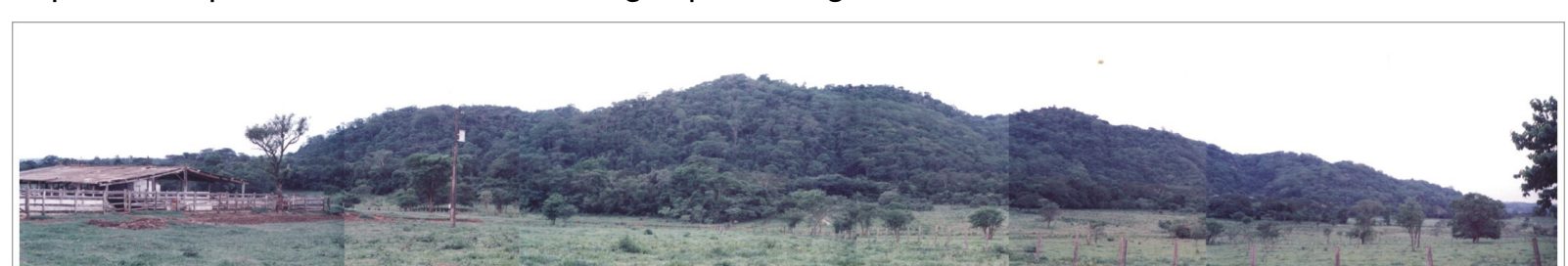

FOTOMONTAGEM do maciço Quenta-Sol, localizado na porção norte da Província: mais de 25 sítios préhistóricos foram registrados aqui.

Incursões em regiões vizinhas, fora do ambiente cárstico acima delimitado, também foram realizadas, com descobertas no município de Lagoa da Prata, ao norte, e ao sul no município de Carmo do Rio Claro, esse já na bacia do rio Grande. 
A região foi escolhida para a realização de dois projetos de mestrado: um abordando a ocupação de horticultores ceramistas, outra contemplando os grupos caçadores pré-ceramistas. Trata-se, portanto, de trabalhos complementares que buscam elucidar a ocupação pré-histórica da região.

O primeiro projeto, defendido em março de 2006, abordou a problemática da cerâmica relacionada às relações espaço-temporais e estilísticas das manifestações Una e Sapucaí. As relações entre as duas culturas materiais não puderam ser esclarecidas satisfatoriamente por causa da falta de pacotes sedimentares com profundidade, onde as duas culturas materiais estariam representadas. Os sítios escavados foram Gruta Mané do Juquinha e Engenho de Serra. Apesar dessas limitações, o trabalho comprovou a ocupação do interior de cavernas por grupos horticultores no período de pré-contato com os europeus. Além disso, que os horticultores, portadores da tradição Sapucaí, estariam produzindo estruturas ao modo das "casas subterrâneas" (sitio Engenho de Serra), vestígios comuns do Sul do Brasil, que ocorrem associados às tradições Taquara/Itararé (HENRIQUES JR, 2006).

\begin{tabular}{lcccc}
\multicolumn{1}{c}{ Tabela : Datações radiocarbônicas relacionadas à ocupação de grupos ceramistas na Província. } \\
\hline $\begin{array}{l}\text { Sítio - Código } \\
\text { amostra }\end{array}$ & Município & Data Radiocarbônica & $\begin{array}{c}\text { Anos Calêndricos } \\
\text { (calibrada) }\end{array}$ & Código Laboratório \\
$\begin{array}{l}\text { Buracão dos Bichos } \\
\begin{array}{l}\text { Loca do Suim - } \\
\text { LDS1690 }\end{array}\end{array}$ & Piumhí & $1840 \pm 90$ AP & - & SI 2368 \\
$\begin{array}{l}\text { Buracão dos Bichos } \\
\begin{array}{l}\text { Engenho de Serra - } \\
\text { ES1850 }\end{array}\end{array}$ & Piumhí & $1000 \pm 90$ AP & 690 a 780 DC & Beta 210726 \\
$\begin{array}{l}\text { Mané do Juquinha } \\
\text { MDJ-GE-227 }\end{array}$ & Pains & $830 \pm 40$ AP & 1230 a 1280 DC & Beta 210727 \\
$\begin{array}{l}\text { Mané do Juquinha } \\
\text { MDJ-GE-133 }\end{array}$ & Pains & $610 \pm 50$ AP & 1300 a 1410 DC & Beta 193755 \\
\hline
\end{tabular}

No que diz respeito à ocupação dos caçadores-coletores, sabe-se que o final do período pleistocênico corresponde à entrada inicial deles no continente sul-americano. Os vestígios mais antigos desses habitantes no Brasil Central aparecem nas camadas arqueológicas entre $10 \mathrm{mil}$ e $12 \mathrm{mil}$ anos AP. As evidências se multiplicam a partir de 10 mil anos AP, demonstrando que a ocupação de praticamente todos nichos ecológicos estava consolidada.

O interesse em reunir evidências para comprovar a existência de uma ocupação précerâmica também na Província Cárstica do Alto São Francisco foi o principal motivador deste projeto. Para caracterizar essa população pré-histórica foi escolhido o tipo de vestígio mais durável associado a ela: a indústria lascada. Uma amostra quantitativa- e qualitativamente importante foi obtida a partir de escavações em duas cavernas - Loca do Suim e Gruta do 
Marinheiro - e coletas seletivas de peças significativas em diversos sítios. Além disso, foi incorporada à análise uma amostra de 152 peças obtidas no Abrigo Lagoa de Peixe I em 1999.

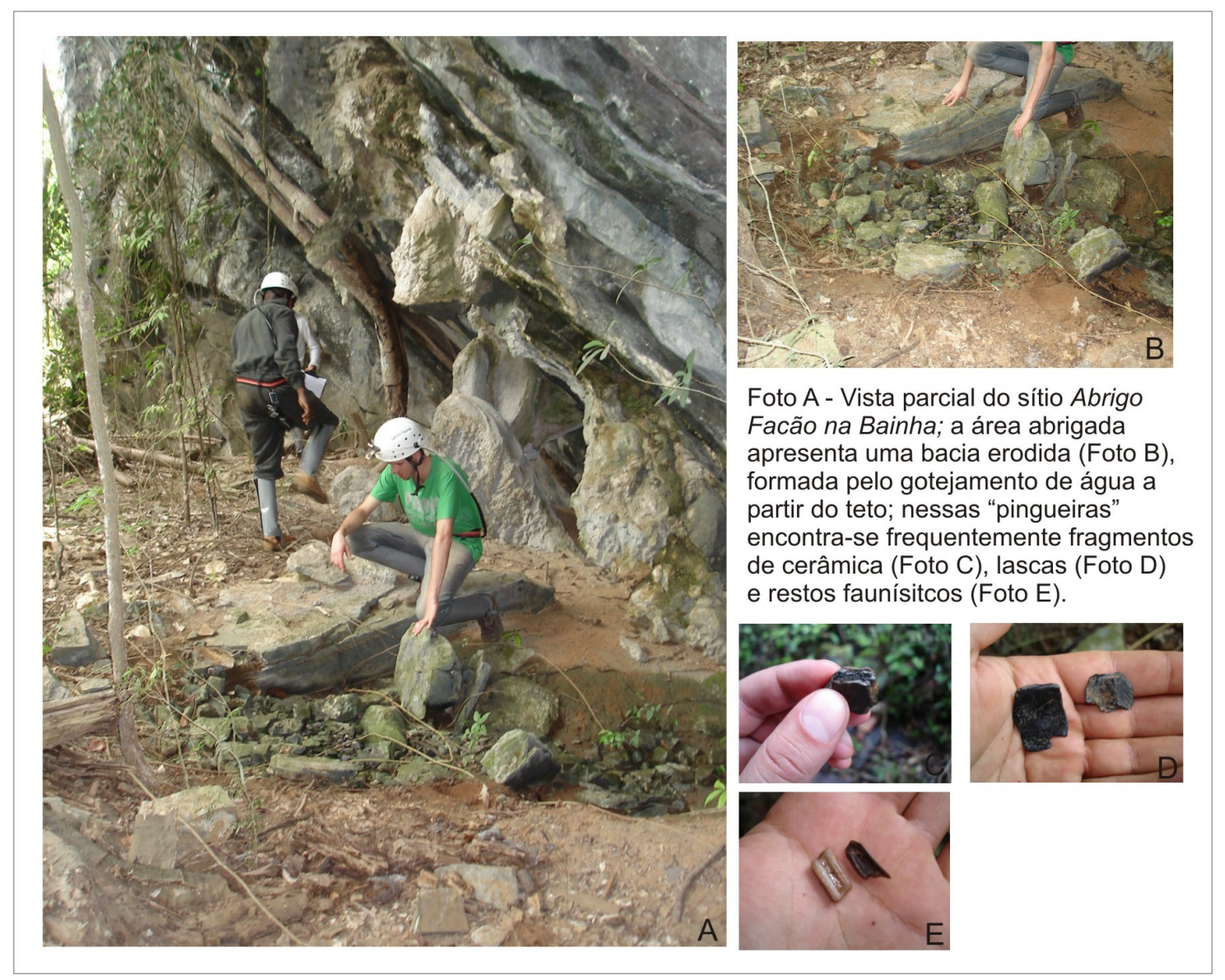




\section{CAPÍTULO 4 - OS SÍTIOS ARQUEOLÓGICOS}

Dos 192 sítios em cavernas, abrigos e a céu aberto conhecidos na região, 37\% foram registrados pelo IAB e Setor de Arqueologia nos anos 1970 (71 sítios). Os 63\% restantes foram levantados nos últimos sete anos, principalmente em função de trabalhos de consultoria ambiental (121 sítios). Encontrou-se também 31 ocorrências líticas a céu aberto. Para a escolha dos sítios que fariam parte deste projeto foram contemplados os sítios e ocorrências levantados nesses últimos anos. Quase todos os sítios em abrigos e cavernas apresentam sedimentos preservados ou passíveis de serem escavados; os sítios a céu aberto foram mais impactados pela atividade agropecuária.

Os levantamentos de superfície revelaram um contexto de deposição recorrente nos sítios abrigados. Em superfície, nas áreas secas, próximas às paredes laterais e/ou no centro dos abrigos (e nas entradas de cavernas), notou-se a existência de sedimento cinza pulverulento com partes brancas que se destacavam do piso. Tratava-se de estruturas de combustão, resquícios de fogueiras, freqüentemente acompanhadas de fragmentos cerâmicos, em alguns casos também de artefatos polidos e/ou picoteados como lâminas e pilões, e brutos como bigornas. Nos locais sujeitos a erosão, no limite da área abrigada (linha de goteira) ou em áreas com bacias de gotejamento, onde o sedimento superficial havia sido carregado pela água, encontrou-se freqüentemente material lascado de pequenas dimensões, restos faunísticos e carvões esparsos (às vezes também pequenos fragmentos de cerâmica). Do total, 21 sítios apresentaram vestígios lascados nessas condições: 9 em abrigo, 12 em caverna.

A maior parte dos sítios registrados nos anos 1970 ainda não foram localizados, o que se deve principalmente à falta de coordenadas georeferenciadas e, como também não mencionaram vestígios lascados nesses sítios nas quantidades que interessam aqui, a localização deles não foi priorizada. Os sítios que precisam ser reencontrados são aqueles levantados pelo IAB, com exceção de alguns, entre eles o Buracão dos Bichos (UTM: $387720 E$ e $7749365 \mathrm{~N}$ ), e outros com estruturas de casas subterrâneas, registrados pelo Setor, localizados na barra do rio São Miguel, no município de Iguatama. O Buracão, localizado na barra do Córrego Grande, um afluente da margem direita do rio São Francisco, foi o único sítio escavado (por arqueólogos) na região até 2003.

A amostra lítica coletada provém principalmente de três sítios: Gruta do Marinheiro, Loca do Suim e Abrigo Lagoa de Peixe I, todos localizados na bacia do Ribeirão dos Patos. Em dez outros sítios (indicados com asterisco na tabela abaixo) foram realizadas coletas seletivas de superfície de objetos significativos, de instrumentos como plano-convexos, raspadores e pontas de projétil. Somente uma peça foi coletada em um sítio a céu aberto (Lagoa do Retiro), as 
outras em 12 sítios abrigados. Até recentemente havia uma falta crônica de peças retocadas, quase a totalidade da amostra era representada por lascas sem retoque, uma lacuna que foi preenchida com coletas de instrumentos encontrados na superfície de diferentes sítios. Cada sítio foi desenhado em planta baixa e a localização precisa dos vestígios coletados foi indicado nela.

Tabela: Relação dos 13 sítios que forneceram a amostra lítica para análise (ver também planta com localização dos sítios e ocorrências).

\begin{tabular}{llcc}
\hline \multicolumn{1}{c}{ SítIOS } & TIPO & COORDENADAS \\
& & UTM \\
01 & Abrigo Lagoa do Peixe I & Abrigo & 415029 E / 7753107 N \\
02 & Loca do Suim & Caverna & 417314 E / 7752410 N \\
03 & Gruta do Marinheiro & Caverna & 415156 E / 7743953 N \\
04 & Abrigo dos Riscos* & Abrigo & 415838 E / 7757211 N \\
05 & Gruta do Ângelo* & Caverna & 416367 E / 7757072 N \\
06 & Loca Zizinho Beiraldo* & Caverna & 413286 E / 7748723 N \\
07 & Gruta da Perdição I* & Caverna & 422527 E / 7746245 N \\
08 & Abrigo dos Macacos* & Abrigo & 431350 E / 7760010 N \\
09 & Gruta Antônio Vitalino* & Caverna & 431554 E / 7759624 N \\
10 & Abrigo da Mureta* & Abrigo & 432597 E / 7758660 N \\
11 & Abrigo da Estiva* & Abrigo & 439996 E / 7742180 N \\
12 & Abrigo Lagoa do Retiro* & Abrigo & 437890 E / 7741210 N \\
13 & Lagoa do Retiro* & Céu Aberto & 437808 E / 7740936 N \\
\hline
\end{tabular}

\section{1 - Abrigos.}

Os abrigos são caracterizados por apresentarem uma abertura ou largura da entrada maior que a profundidade. Apesar das dimensões da área abrigada poder variar sensivelmente, a maioria dos sítios em abrigos são relativamente menores se comparados com aqueles de outras regiões cársticas de Minas. O tamanho, no entanto, não impediu que fossem ocupados pelos caçadores-coletores e, além de relativamente numerosos, estão espalhados por um território amplo. O entorno dos afloramentos calcários são frequentemente desmatados, apresentando pastos ou áreas cultivadas (ver foto abaixo). 


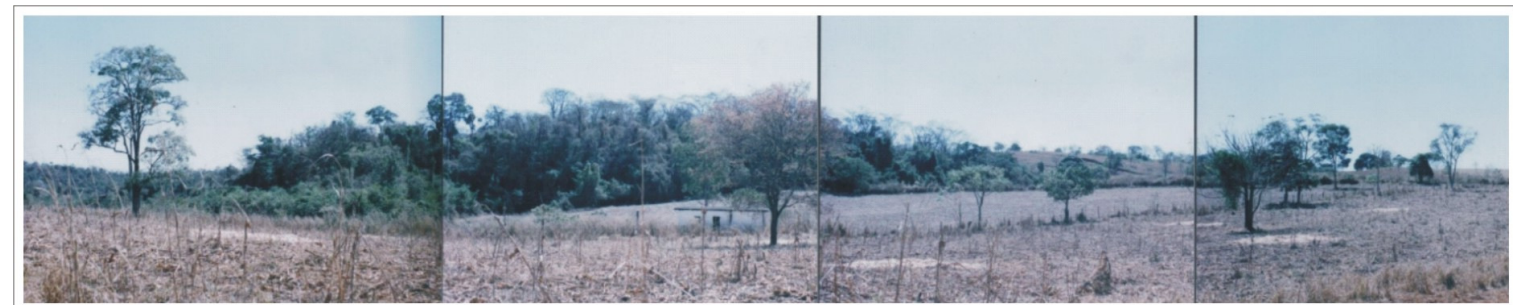

FOTO: Fotomontagem com vista geral do afloramento onde se encontra o Abrigo da Estiva, na borda sudeste da Província.

Como foi mencionado anteriormente, vestígios lascados, inclusive peças retocadas, são encontradas em superfície, nas chamadas pingueiras, como ocorre no sítio Abrigo Lagoa do Retiro (ver planta baixa). Excepcionalmente também foram detectados delgadas lascas incrustadas em pisos estalagmíticos quebrados ${ }^{23}$, o que foi o caso para o sítio Abrigo da Mureta (ver planta baixa). Esse fenômeno parece bastante sugestivo para a atribuição de uma certa antigüidade à ocupação pré-histórica da região (por causa do tempo necessário para a formação de tais pisos).

${ }^{23}$ Trata-se de uma mistura de sedimento concrecionado com blocos de calcário e calcita. 


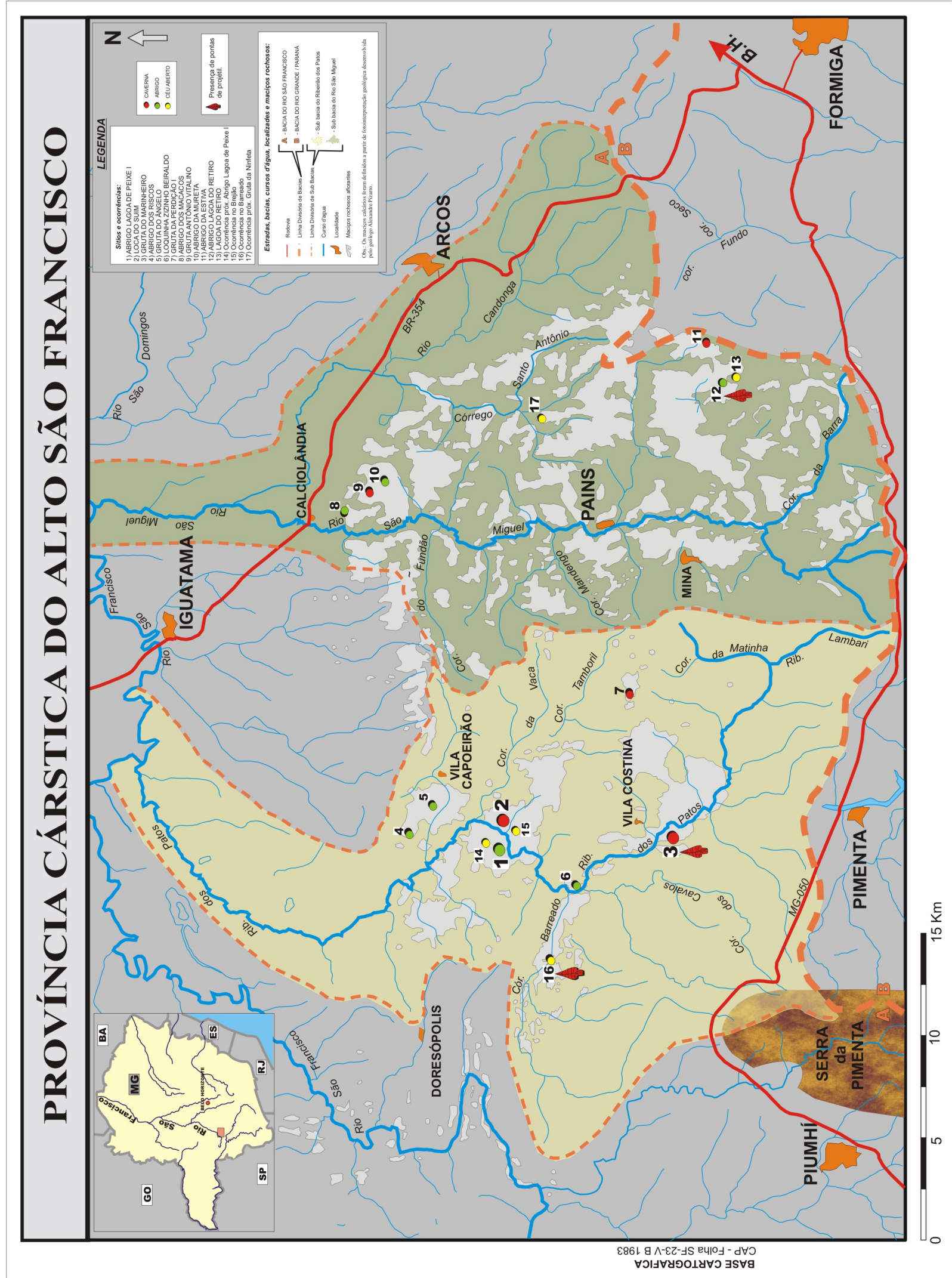




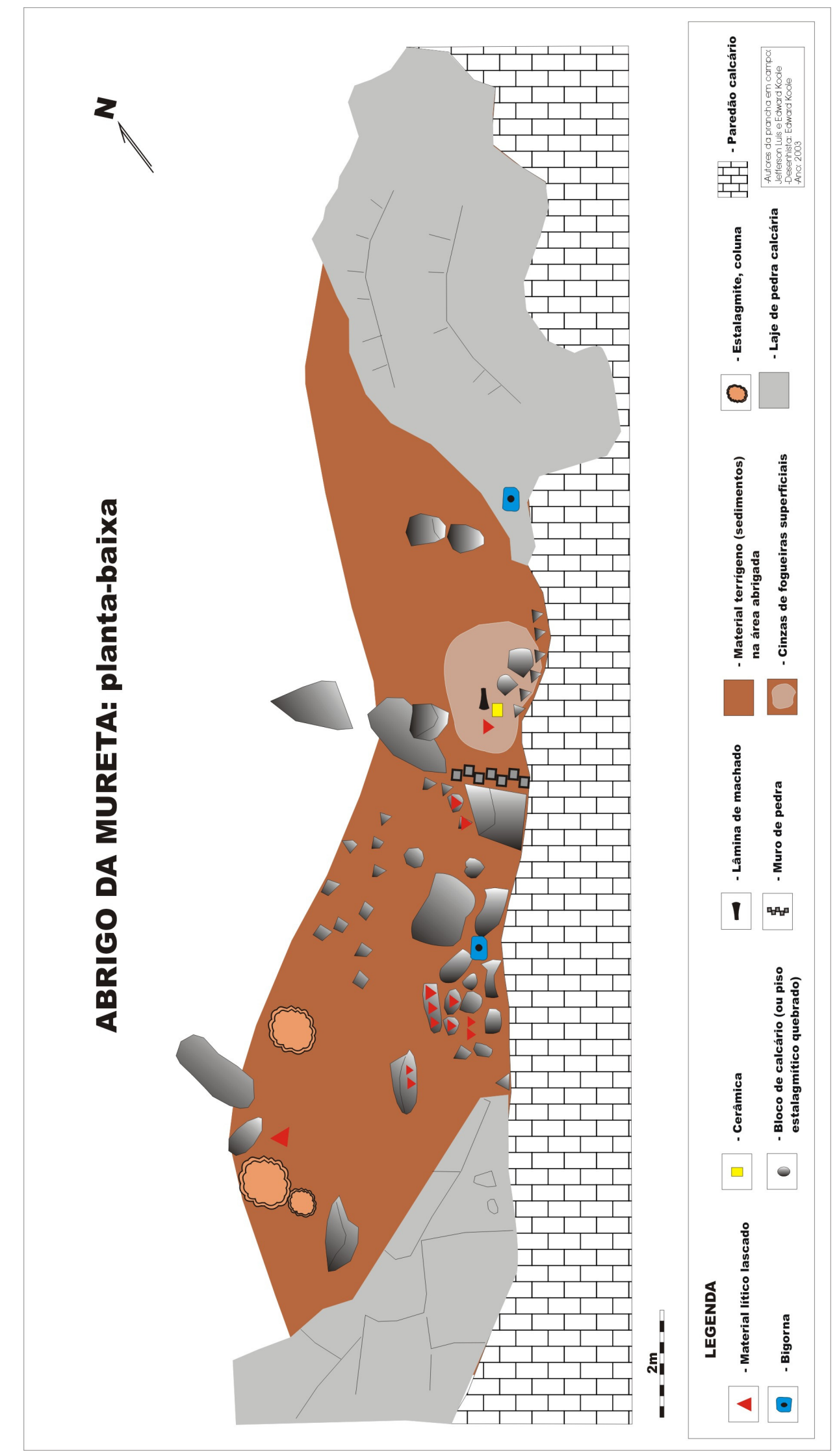


$\frac{1}{2}$

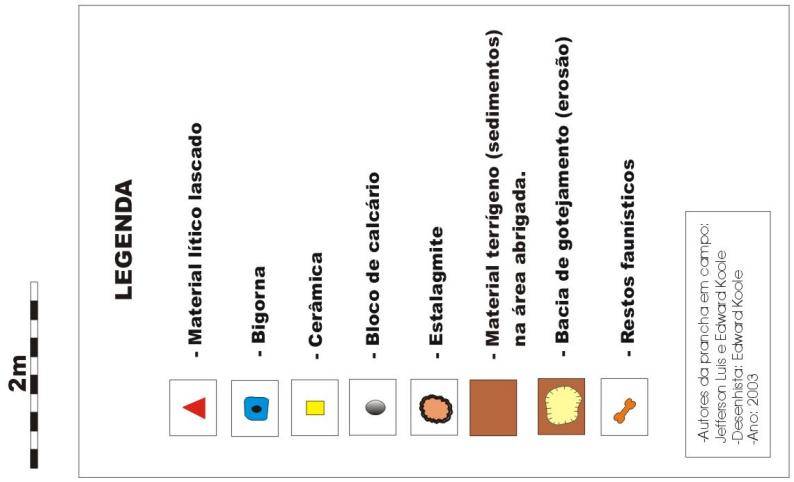

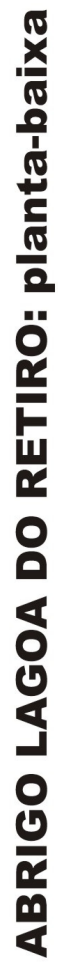




\subsection{1 - Abrigo Lagoa de Peixe I}

O abrigo, localizado em uma vertente dentro de uma área de pastagem tem sua entrada encoberta por capoeira. Ele se encontra a cerca de $50 \mathrm{~m}$ de um olho d'água e a $200 \mathrm{~m}$ da Lagoa da Fumaça, localizada próxima à margem esquerda do Ribeirão dos Patos. Trata-se de um pequeno abrigo que apresenta $10 \mathrm{~m}$ de largura com abertura para SW, até $6 \mathrm{~m}$ de profundidade e até $4 \mathrm{~m}$ de altura máxima. Em sua subsuperfície, a poucos centímetros de profundidade, encontra-se um horizonte lítico, perceptível nos locais erodidos no limite da área abrigada e nas bacias de gotejamento d'água na porção abrigada. O sítio foi objeto de uma coleta sistemática de superfície em 1999 e as 152 peças líticas recuperadas foram analisadas em laboratório (HENRIQUES Jr., COSTA \& KOOLE, 2001).

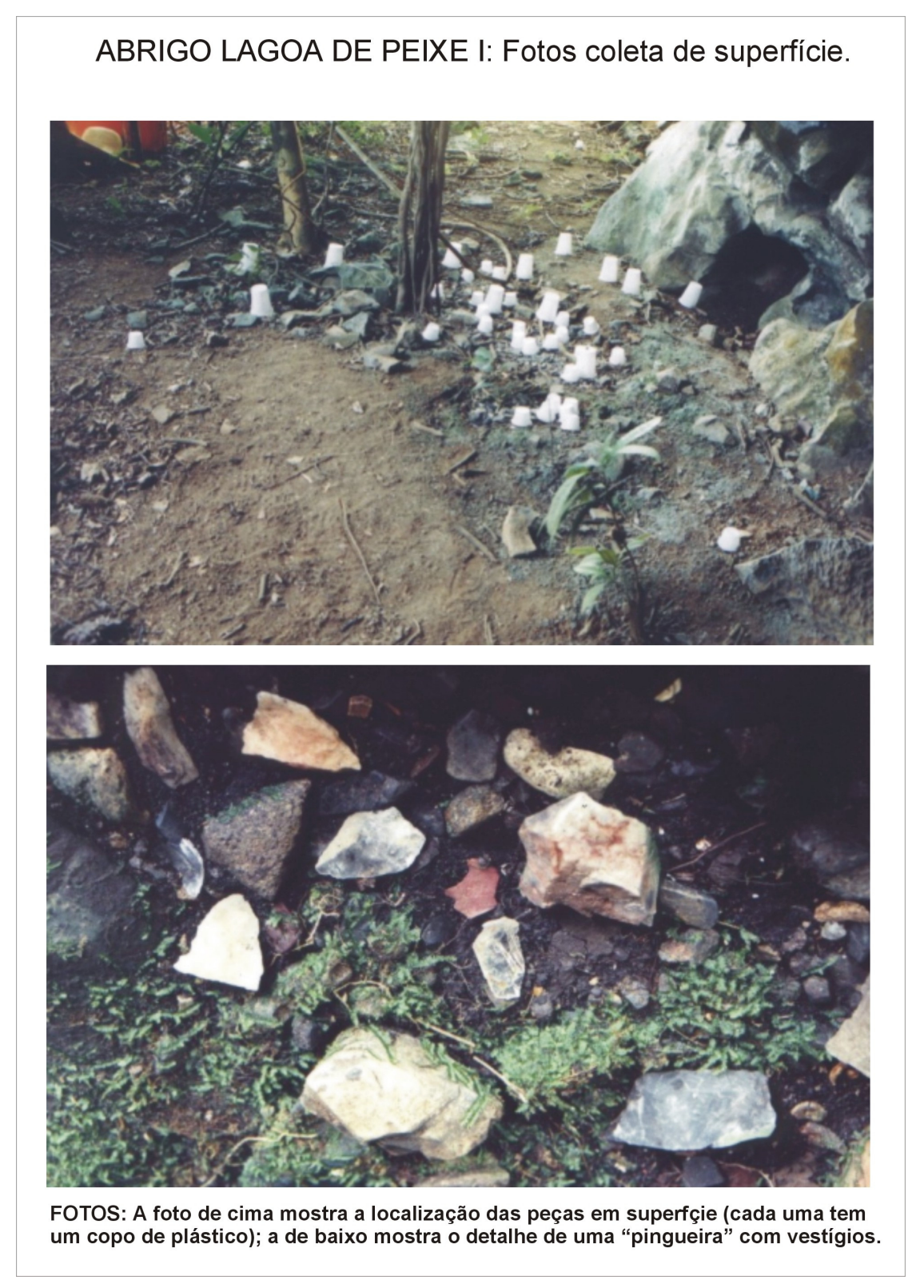




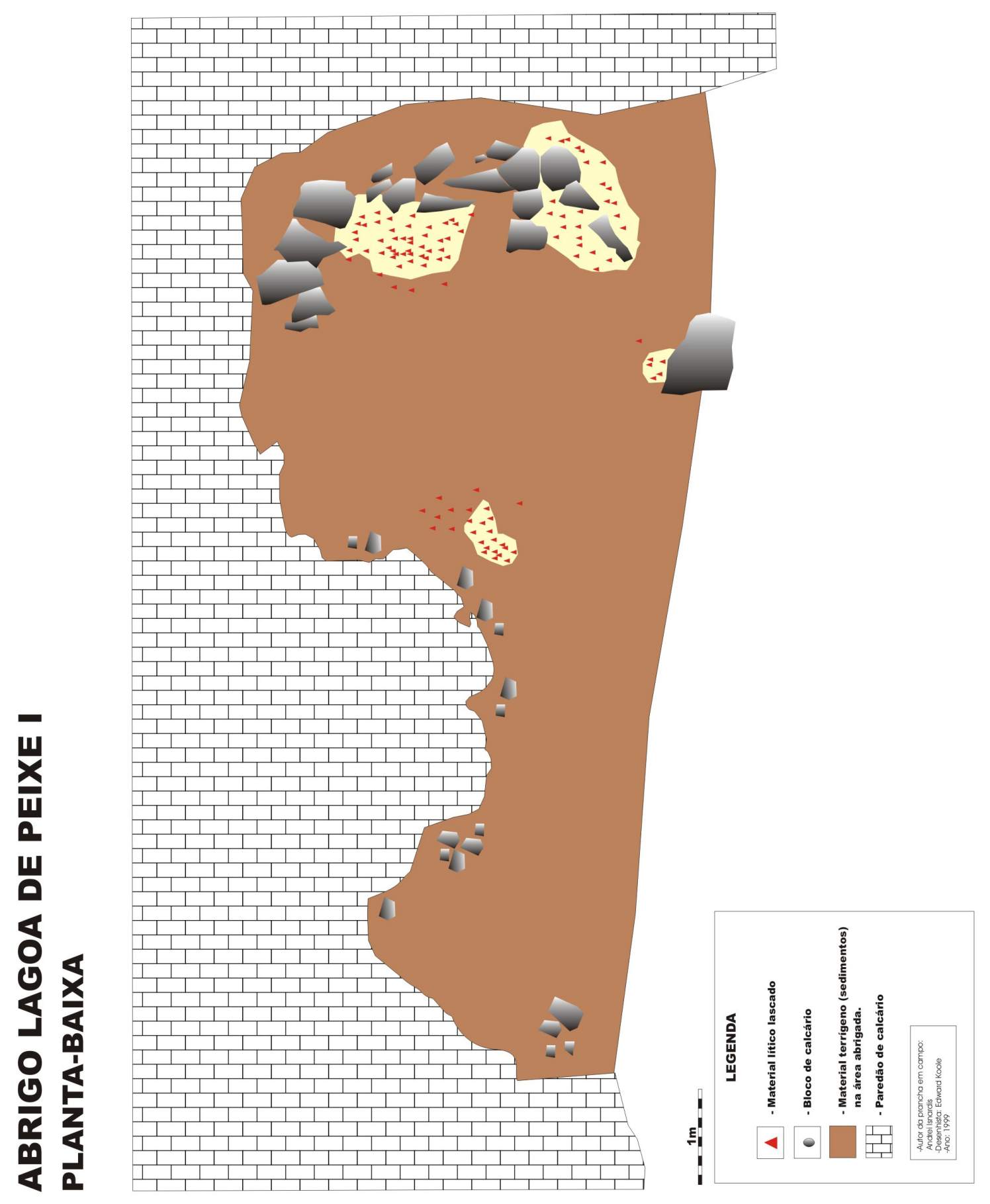




\section{2 - Cavernas.}

As cavernas ou grutas são caracterizadas por terem, ao contrário dos abrigos, uma profundidade maior do que a largura de sua entrada. Pode-se afirmar que as entradas das cavernas, ou seja, as partes mais arejadas e iluminadas, forneciam uma proteção semelhante à dos abrigos. Em algumas cavernas a parte interna também foi utilizada, principalmente por grupos horticultores tardios como testemunharam duas estruturas de combustão datadas associadas a restos faunísticos e cerâmica na Gruta Mané do Juquinha (HENRIQUES, 2006).

\subsection{1 - Loca do Suim}

A Loca do Suim é uma caverna que está localizada na região da Mata das Frutas, no sopé do Morro da Menina, município de Pains. O Morro é um grande maciço calcário parcialmente encoberto por solo (no topo e em algumas vertentes), formando paredões com cavernas e abrigos nas vertentes próximas ao Ribeirão dos Patos, a oeste e ao sul. A Loca se encontra na porção centro-sul do referido maciço e apresenta desenvolvimento linear de $120 \mathrm{~m}$, com duas entradas interligadas por condutos e um salão. Inicialmente foi localizado apenas uma peça lascada em superfície, no entanto, a caverna mostrou-se favorável por causa da presença de sedimentos secos. Na boca principal, com forma de funil, entre grandes blocos de calcário, foi realizada uma sondagem de reconhecimento no final de $2003^{24}$. A sondagem de $50 \times 50 \mathrm{~cm}^{2}$ revelou uma alta concentração de ossos humanos, acompanhado por lascas e carvões, a partir de $25 \mathrm{~cm}$ de profundidade. Por causa dos ossos humanos decidiu-se interromper a escavação com $40 \mathrm{~cm}$, para ampliá-la no ano seguinte.

Em 2004 começou-se pela topografia e quadriculamento de quatro unidades a serem escavadas em diferentes áreas da entrada, utilizando-se a estação total. A sondagem do ano anterior foi incorporada na Unidade 1 (U1), como quadrante SW. A abertura dessa unidade, no entanto, não conseguiu abranger todo sepultamento e ainda revelou outro na sua parede leste. Ambos se encontravam no limite da unidade e portanto foi necessário ampliar de novo a escavação para a recuperação completa dos dois enterramentos, totalizando assim $2,84 \mathrm{~m}^{2}$. Além da escavação principal, que passou a se chamar Área 1, foram abertas mais 3 unidades em diferentes áreas do sítio.

\footnotetext{
${ }^{24}$ Tratou-se da primeira escavação na Província desde os anos 1970.
} 


\section{Fotos do Morro da Menina}
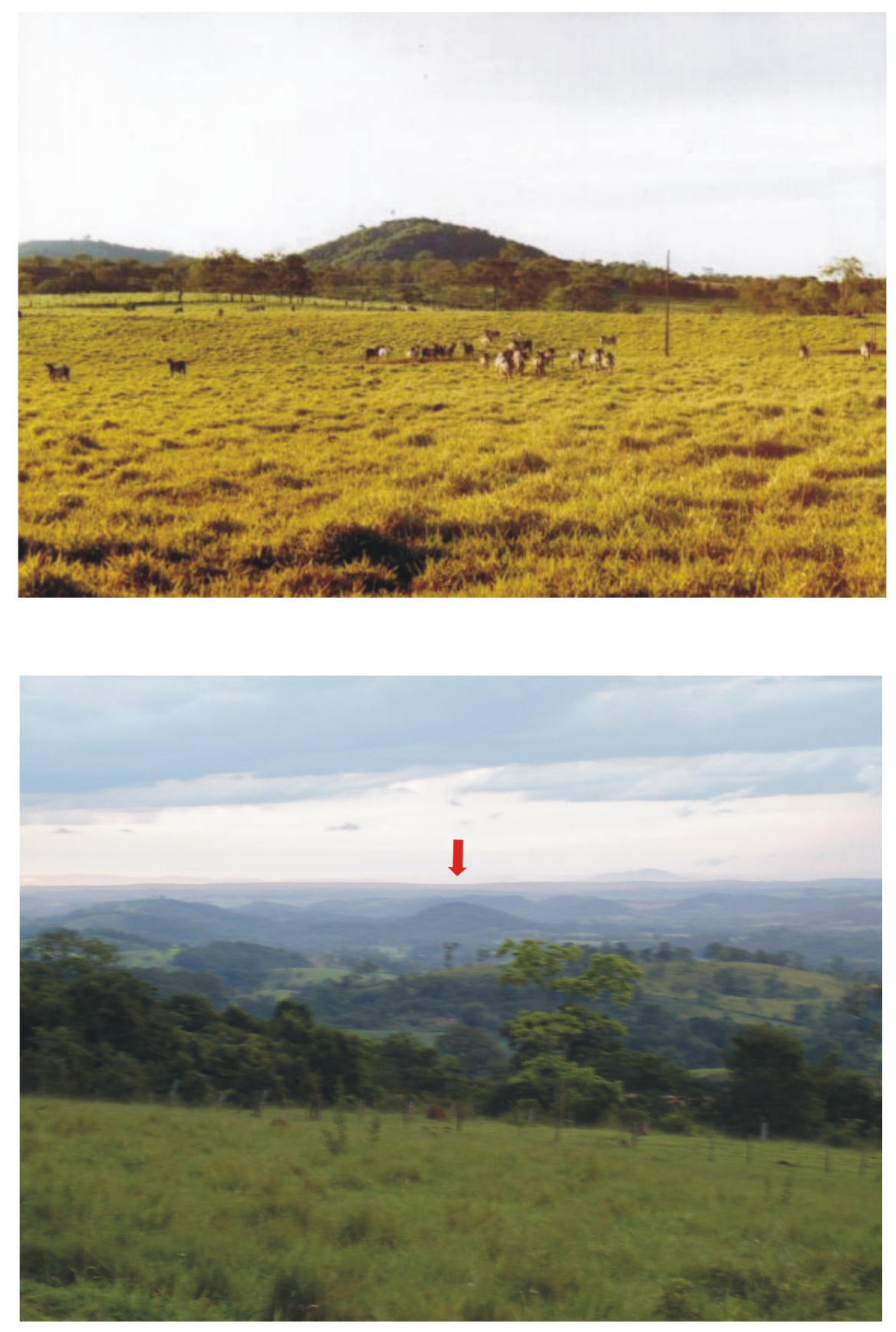

Visualização do Morro da Menina (indicado pela seta vermelha) a partir do interflúvio entre as micro-bacias do Rio São Miguel e Ribeirão do Patos. A Loca do Suim se encontra nesse maciço. 


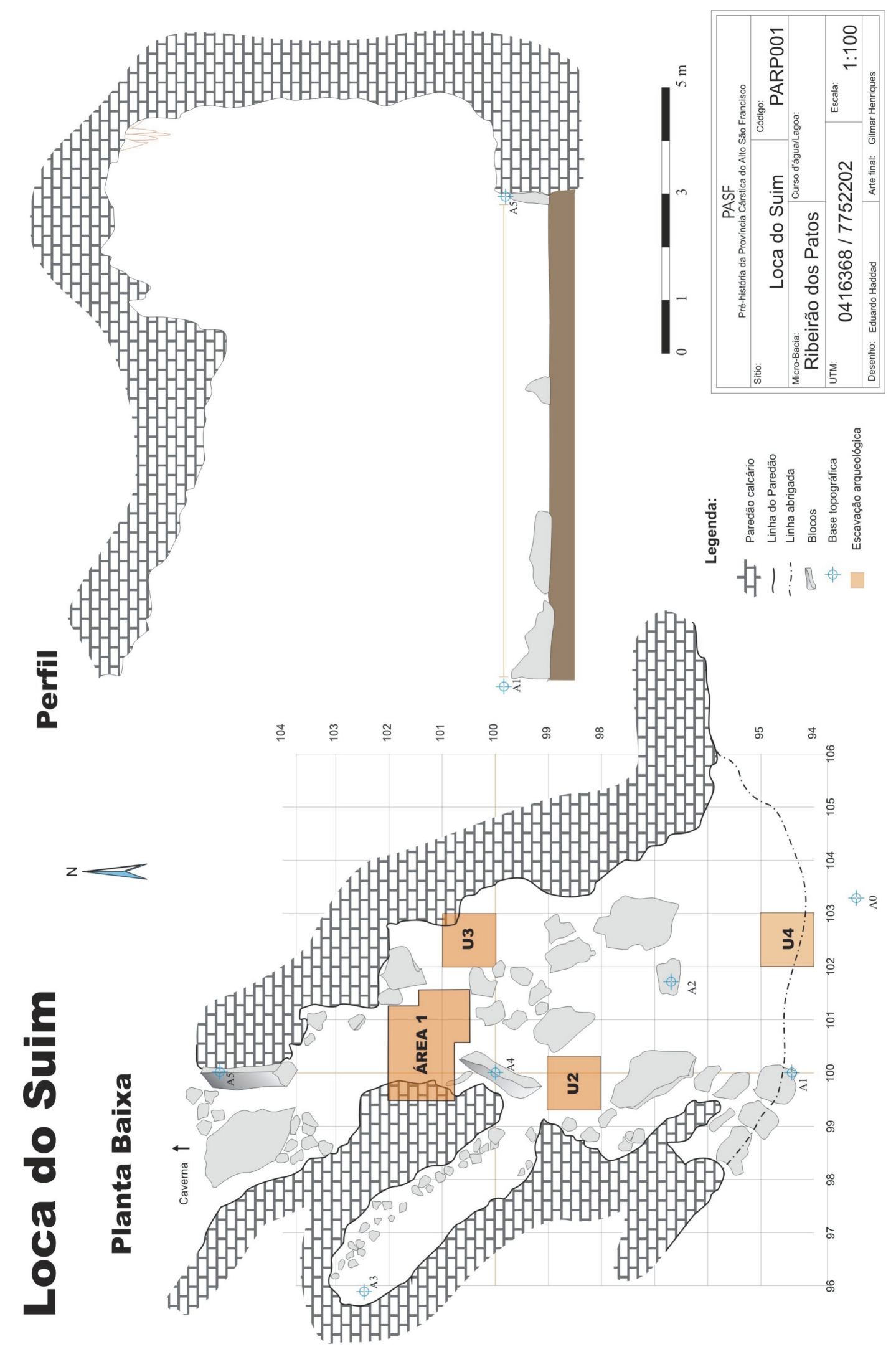


A área total escavada no sítio foi, portanto, 5,84 m2. Na escavação principal, que foi uma ampliação da U1, encontrou-se duas covas com ossos humanos a partir do nível $20-30 \mathrm{~cm}$ até o nível $50-60 \mathrm{~cm}$. O Sepultamento II apresentou boas evidências de um enterramento primário, em decúbito lateral, com as pernas e braços fletidos. O Sepultamento I se mostrou mais complexo em termos tafonômicos, apresentando duas concentrações de ossos: uma mais superficial, parcialmente queimada, parecendo com um sepultamento secundário; outra, no fundo da cova, mais completa, entretanto, com pouca evidência de articulação entre os ossos, parecendo com um sepultamento primário perturbado.

Os ossos humanos dos Sepultamentos I e II foram encaminhados para o Laboratório de Estudos Evolutivos Humanos do Instituto Biológico, Departamento de Genética e Biologia Evolutiva, da Universidade de São Paulo, onde foram curados e analisados entre abril de 2006 e junho de $2007^{25}$. Esse trabalho demonstrou tratar-se de quatro indivíduos no Sepultamento I, dois dos quais, menos preservados, parecem intrusivos (ver relatório de curadoria em anexo).

$\mathrm{Na}$ estratigrafia da Área 1, os dez primeiro centímetros apresentavam uma camada marrom, pulverulenta na superfície, compactando depois de alguns centímetros. A densidade de vestígios era baixa com algumas lascas e fragmentos de cerâmica a partir de $4 \mathrm{~cm}$. A partir de cerca de $10 \mathrm{~cm}$ começa uma camada cinza com manchas brancas, resquícios de fogueiras e blocos de calcário queimados. Essa camada perdurou em alguns locais até cerca de $25 \mathrm{~cm}$, quando começaram a aparecer os primeiros ossos humanos nas porções sudoeste (SW) e sudeste (SE) da escavação. Nessa camada encontrou-se uma boa quantidade de vestígios líticos, e também alguns fragmentos de cerâmica (até $21 \mathrm{~cm}$ de profundidade). Uma datação foi obtida a partir de um carvão coletado a $16 \mathrm{~cm}$ de profundidade, associado a um fragmento de cerâmica. Nas unidades 2 e 3 encontrou-se uma baixa densidade de vestígios líticos, além de carvões e cinzas superficiais. Na unidade 4 apenas uma baixa densidade de material lítico.

\footnotetext{
${ }^{25}$ Responsáveis: ANDRÉ MENEZES STRAUSS e PEDRO JOSÉ TÓTORA DA GLÓRIA; Colaboradores: TATIANE LEITE NUNES e RODRIGO ELIAS DE OLIVEIRA.
} 


\section{LOCA DO SUIM}

ÁREA 1

PERFIL PAREDE NORTE

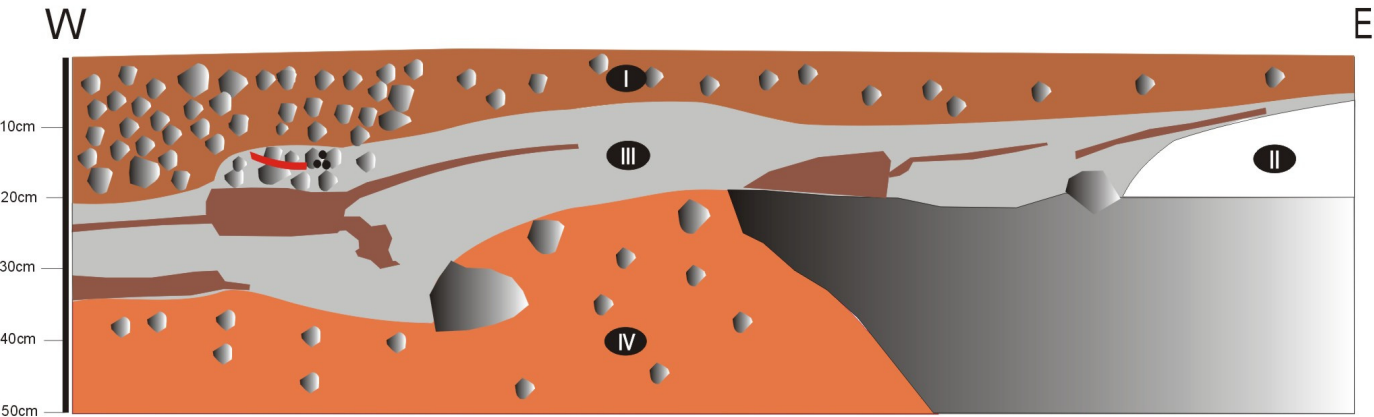

\section{LEGENDA}

\section{Cerâmica}

Raíz

$\therefore \quad$ Carvão datado

- Bloco de calcário

\section{Sedimentos}

(I) Marrom superficial

Sedimento solto e pulverulento com bloquinhos de calcário, ossos de pequenos roedores, restos de insetos, fragmentos de conha e baixa densidade de material lítico e cerâmico. Começa a se compactar para o final do nível 0-10 (7YR 4/2).

\section{Branco antrópico}

Sedimento branco e pulverulento de estrutura de combustão com calcário calcinado.

Cinza antrópico

Sedimento acinzentado e pulverulento com fragmentos de concha, bloquinhos de calcário, carvões, grânulos laranjas, restos faunísticos, vestígios cerâmicos (até $21 \mathrm{~cm}$ ), e material lítico (10YR 5/2)

IV Sedimento estéril

Sedimento avermelhado compactado com blocos de calcário e sem vestígios arqueológicos (7.5YR 5/2). 


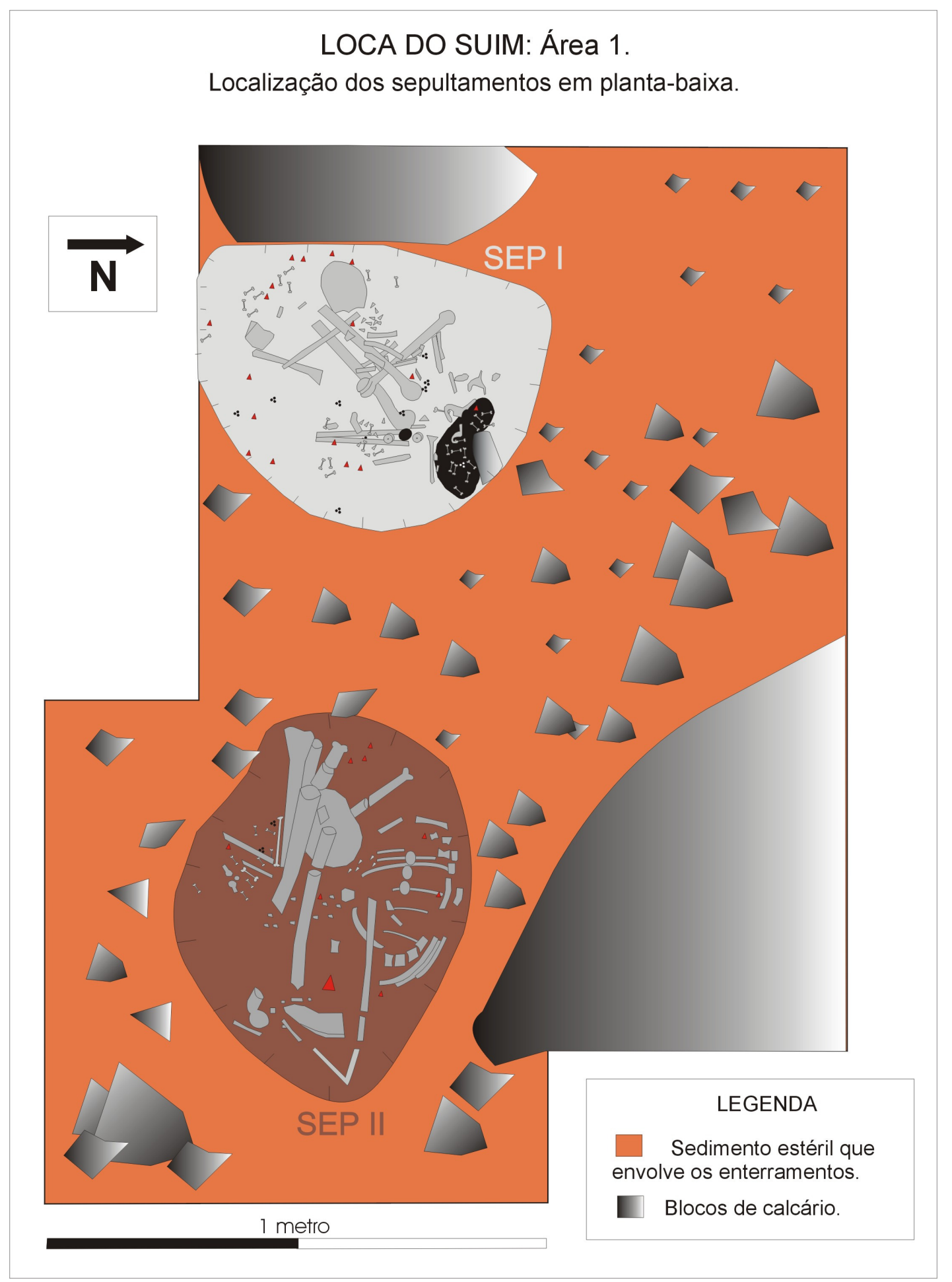



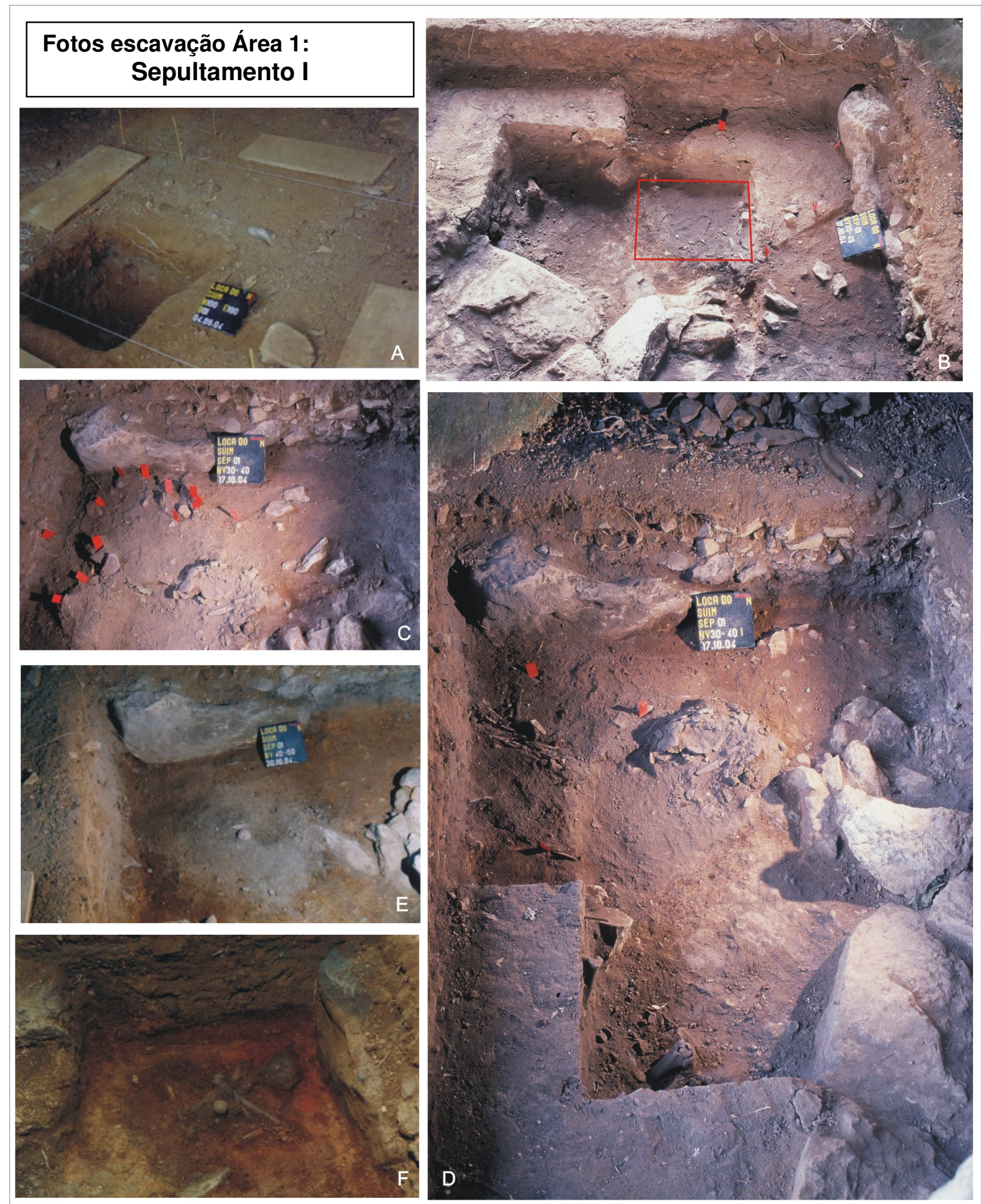

D

As fotos acima mostram o processo de escavação do Sepultamento I: foto A mostra o início das escavações, com a sondagem realizada no final de 2003 na parte sudoeste da quadra; foto B mostra a escavação no início do nível 30-40, com a área sondada anteriormente destacada com um quadrado vermelho; foto $C$ mostra o pacote intermediário do nível 30-40, com destaque para os vestígios líticos (indicados com pequenos retângulos vermelhos); foto $D$ mostra a base do mesmo nível; foto E mostra o nível 40-50, com o aparecimento de uma epífise de osso longo que pertence, como pode ser visto na foto $F$, a um conjunto de ossos mais completos, localizados no fundo da cova. 


\subsection{2 - Gruta do Marinheiro}

A Gruta do Marinheiro é uma caverna localizada na região do Marinheiro, no município de Pimenta, na borda sudoeste da região cárstica. Ela tem um desenvolvimento linear de cerca de $300 \mathrm{~m}$ e se encontra em uma colina com afloramentos de calcário e mata, circundada por áreas cultivadas e pasto. Na base do maciço, há uma lagoa cárstica que é preenchida, sazonalmente, com as águas de um córrego intermitente. A lagoa tem sua água drenada subterraneamente para o Ribeirão dos Patos cujo vale se encontra atrás (do lado nordeste) do referido maciço.

A Gruta do Marinheiro tem quatro entradas independentes (três das quais estão indicadas na fotomontagem abaixo) orientadas para oeste ou noroeste e interligadas por condutos internos. A maior das bocas, Entrada 01 (ao norte), tem mais de 40m de profundidade e apresenta dois patamares separados por uma grande laje de calcário e espeleotemas em forma de colunas (desnível de $3 \mathrm{~m}$ ). O patamar inferior se encontra no limite da área abrigada e apresenta, no seu encontro com o patamar de cima, uma fenda (declividade de $45^{\circ}$ ) parcialmente preenchida por sedimentos e blocos de calcário, além de fragmentos de cerâmica. O patamar superior, que domina $90 \%$ dessa porção da caverna, apresenta lajes de calcário, algumas com gravuras rupestres, alternadas com sedimentos entre blocos de rocha calcária. Essa área, com um piso relativamente plano, está repleta de fragmentos de cerâmica em superfície associados a cinzas de fogueiras, tanto na sua parte bem iluminada quanto no seu interior mais escuro.

Em direção ao sul encontra-se a segunda entrada (Entrada 02) que, ao contrário da anterior, apresenta um patamar inferior amplo com pacote sedimentar significativo. No limite da área abrigada, em locais erodidos pela água da chuva foi encontrado uma alta densidade de material lascado. O piso, com uma inclinação leve para dentro, é constituído por sedimentos e blocos de calcário e apresenta também restos de fogueiras (nas áreas protegidas da ação da chuva), fragmentos de cerâmica e vestígios de pedra polida/picoteada em superfície. Na parte externa, em terreno arado, foram encontrados, espalhados em um diâmetro de cerca de $20 \mathrm{~m}$, várias lascas, um quebra-coco e um fragmento de plano-convexo. Supõe-se, portanto, que o sítio se estende para fora da área abrigada.

$\mathrm{Na}$ terceira entrada encontrou-se material lítico (em menores números), também em locais erodidos, assim como na terra arada logo em frente dessa. Na quarta e última entrada, encontrou-se vestígios apenas em frente dela, na parte externa.

Os locais onde foram realizadas intervenções foram no patamar superior da Entrada 1 (Esc. 1 e 2) e no patamar inferior da Entrada 2 (Esc. 3), em função do sedimento e dos 
vestígios em superfície. As Esc. 1 e 2 foram realizadas em áreas de fogueiras superficiais; a Esc. 3 foi na linha de gotejamento d' água (em locais erodidos).

Tabela: área e espessura dos pacotes escavados nos diferentes setores da Gruta do Marinheiro

\begin{tabular}{lcc}
\hline \multicolumn{1}{c}{ Setor } & Área & Profundidade \\
\hline Esc. 1 & $4 \mathrm{~m}^{2}$ & $40 \mathrm{~cm}$ \\
Esc. 2 & $2 \mathrm{~m}^{2}$ & $40 \mathrm{~cm}$ \\
Esc.3 - Sul & $5 \mathrm{~m}^{2}$ & $70 \mathrm{~cm}$ \\
Esc. 3- Norte & $5 \mathrm{~m}^{2}$ & $55 \mathrm{~cm}$ \\
\hline
\end{tabular}

A Esc. $1\left(4 \mathrm{~m}^{2}\right)$ apresentou quatro níveis artificiais com $10 \mathrm{~cm}$ cada, do nível $0-10 \mathrm{~cm}$ até o $30-40 \mathrm{~cm}$; a Esc. $2\left(2 \mathrm{~m}^{2}\right)$ também teve quatro níveis de $10 \mathrm{~cm}$, do nível $0-10 \mathrm{~cm}$ até o $30-40 \mathrm{~cm}$. A Esc. $3\left(10 \mathrm{~m}^{2}\right)$ foi subdividida em duas quadras iguais: a Norte $\left(5 \mathrm{~m}^{2}\right)$ : apresentou cinco conjuntos de $10 \mathrm{~cm}$ e um de $5 \mathrm{~cm}(20-25 \mathrm{~cm})$, de $0-10$ até $45-55 \mathrm{~cm}$; a Sul $\left(5 \mathrm{~m}^{2}\right)$, sete conjuntos de $10 \mathrm{~cm}$, de $35-45$ até $95-105 \mathrm{~cm}$. 


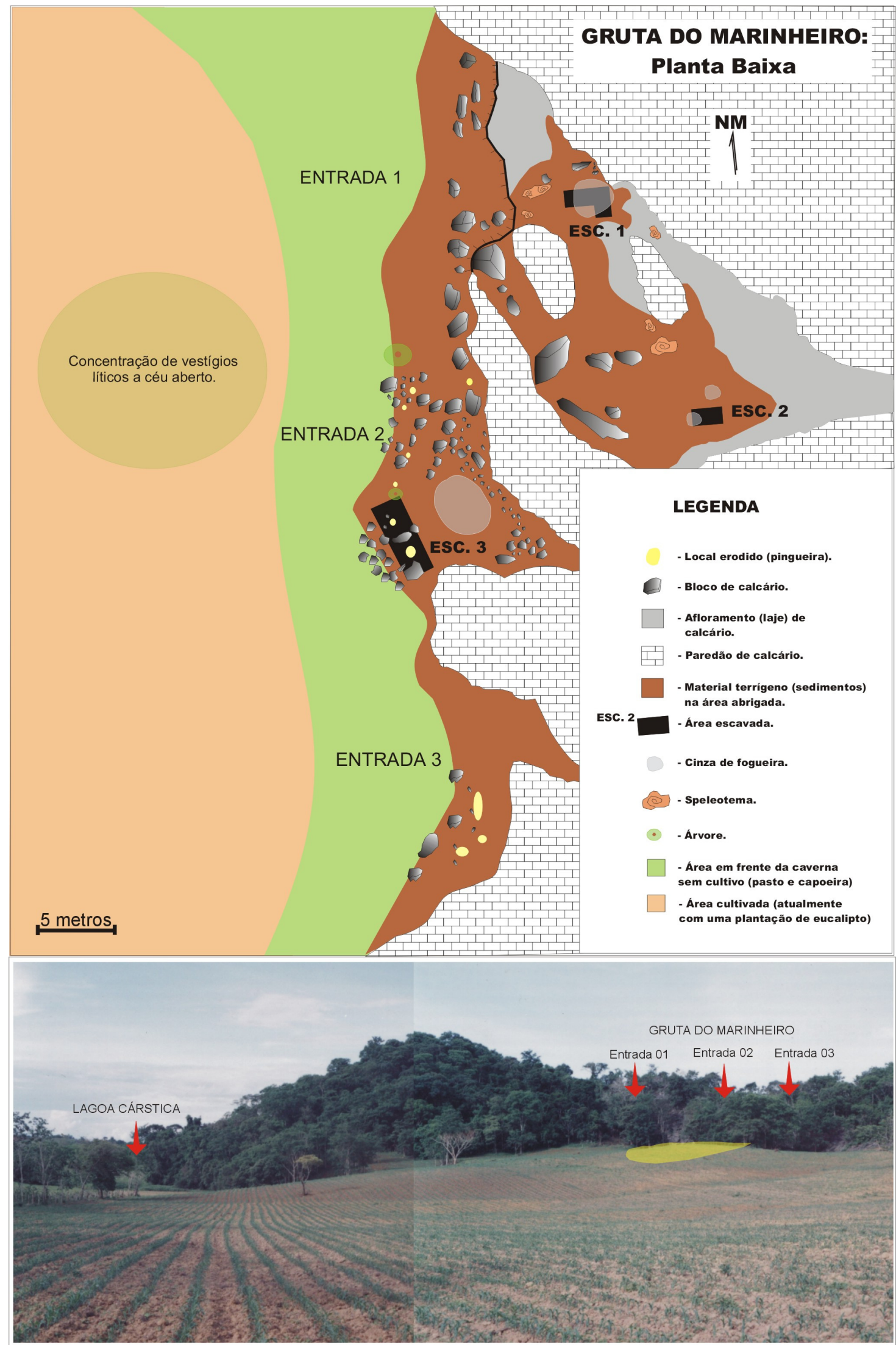

FOTOMONTAGEM com vista geral para o maciço no qual se encontra a Gruta do Marinheiro. Em amarelo, a área, a céu aberto, onde foram encontrados vestígios lascados em superfície. 
Na Escavação 1 (Esc. 1) foram abertos quatro unidades - E, W, S e NW - formando um "L". Esse setor está bem protegido da água da chuva, se encontra próximo às gravuras rupestres e tem estruturas de combustão com contornos bem demarcados, conchas de bivalve e fragmentos cerâmicos em superfície. As camadas I e II (ver perfil em baixo), juntas com, em média, 5 a $10 \mathrm{~cm}$ de espessura, representavam uma continuidade dessas fogueiras com fragmentos cerâmicos, restos faunísticos, além de estruturas escavadas (dois tipos de buracos). O aparecimento do lítico se deu abaixo dessas, nas camadas III e IV. Essas atingiram juntas até $25 \mathrm{~cm}$ de espessura e apresentavam (apesar da diferença de cor e compactação) uma notável semelhança: uma ausência total de cerâmica e um aumento geral (em todas unidades) da densidade do material lítico lascado.

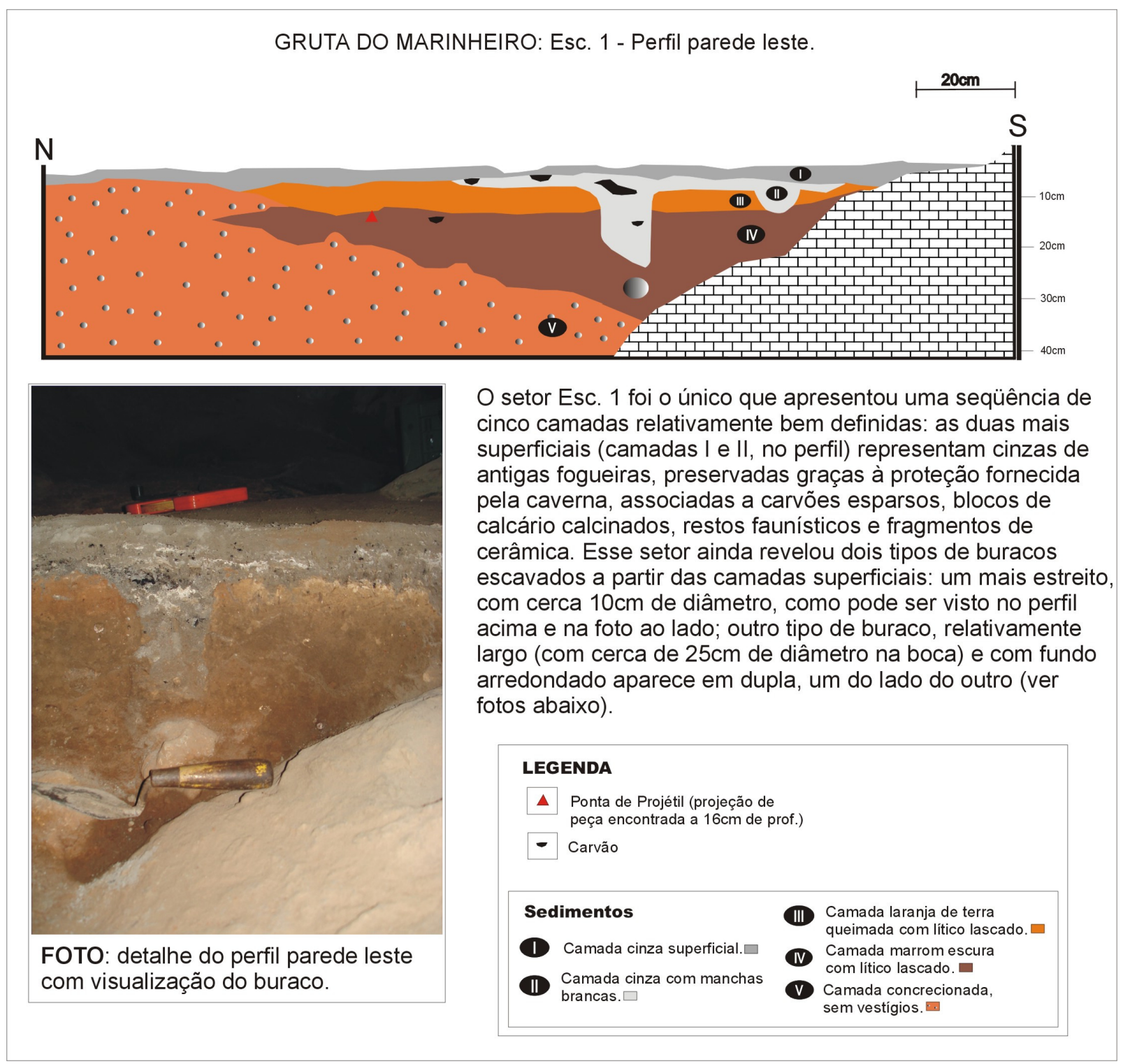


Acredita-se que a ação das fogueiras superficiais, atribuídas a grupos de horticultoresceramistas (camadas I e II), foi a responsável por transformar os $5 \mathrm{~cm}$ superiores de um pacote escuro e relativamente homogêneo, em uma camada endurecida e alaranjada, alterada pela ação do fogo (correspondente à camada III no perfil). Pelo perfil da parede leste, as camadas III e IV preencheram um buraco, nivelando dessa maneira o piso da caverna. Abaixo de $35 \mathrm{~cm}$ aparece um sedimento estéril, bastante compactado e com muitos blocos de calcário (Camada $\mathrm{V})$.

A mudança brusca entre o contexto superficial (ceramista), representada pelas camadas I e II, e um mais profundo (pré-ceramista), camadas III e IV, aponta para uma certa estabilidade do ambiente no período entre as duas ocupações; em outras palavras, não houve uma sedimentação natural que separasse as duas ocupações. Entretanto, não sabe-se ainda quanto tempo esse intervalo durou porque nenhuma datação radiocarbônica foi obtida para esse Setor do sítio.

Nas quatro unidades foram retiradas 1459 peças líticas $(2,8 \mathrm{Kg})$, correspondente a $6 \%$ da amostra total do sítio. Apresentou somente uma ponta de projétil fragmentada a $16 \mathrm{~cm}$ de profundidade, o que indica que não havia um descarte intenso de instrumentos bifaciais no setor Esc. 1. 


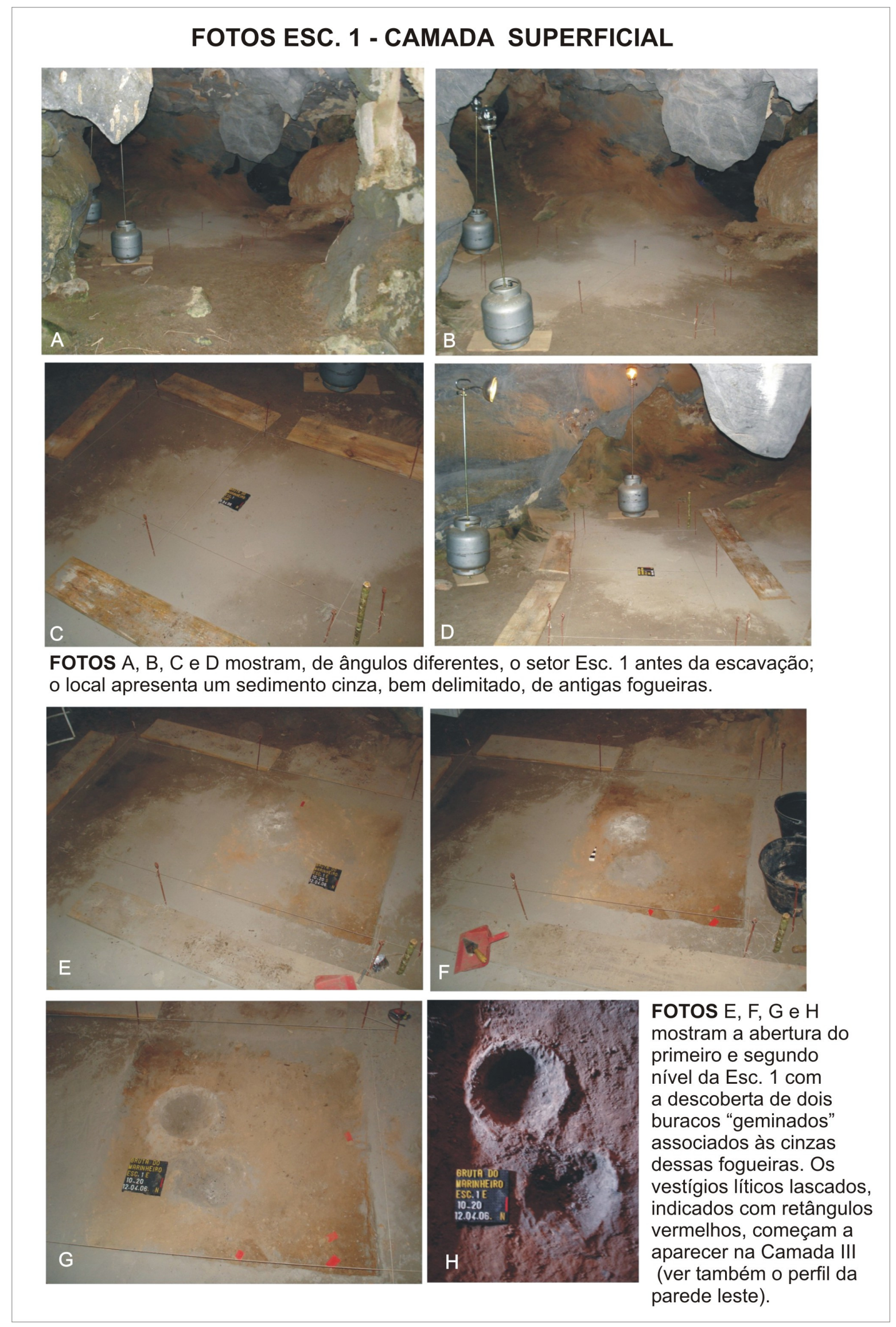


$\mathrm{Na}$ Esc. 2 a camada antrópica é superficial e associada a vestígios de grupos ceramistas (não forneceu uma amostra lítica).

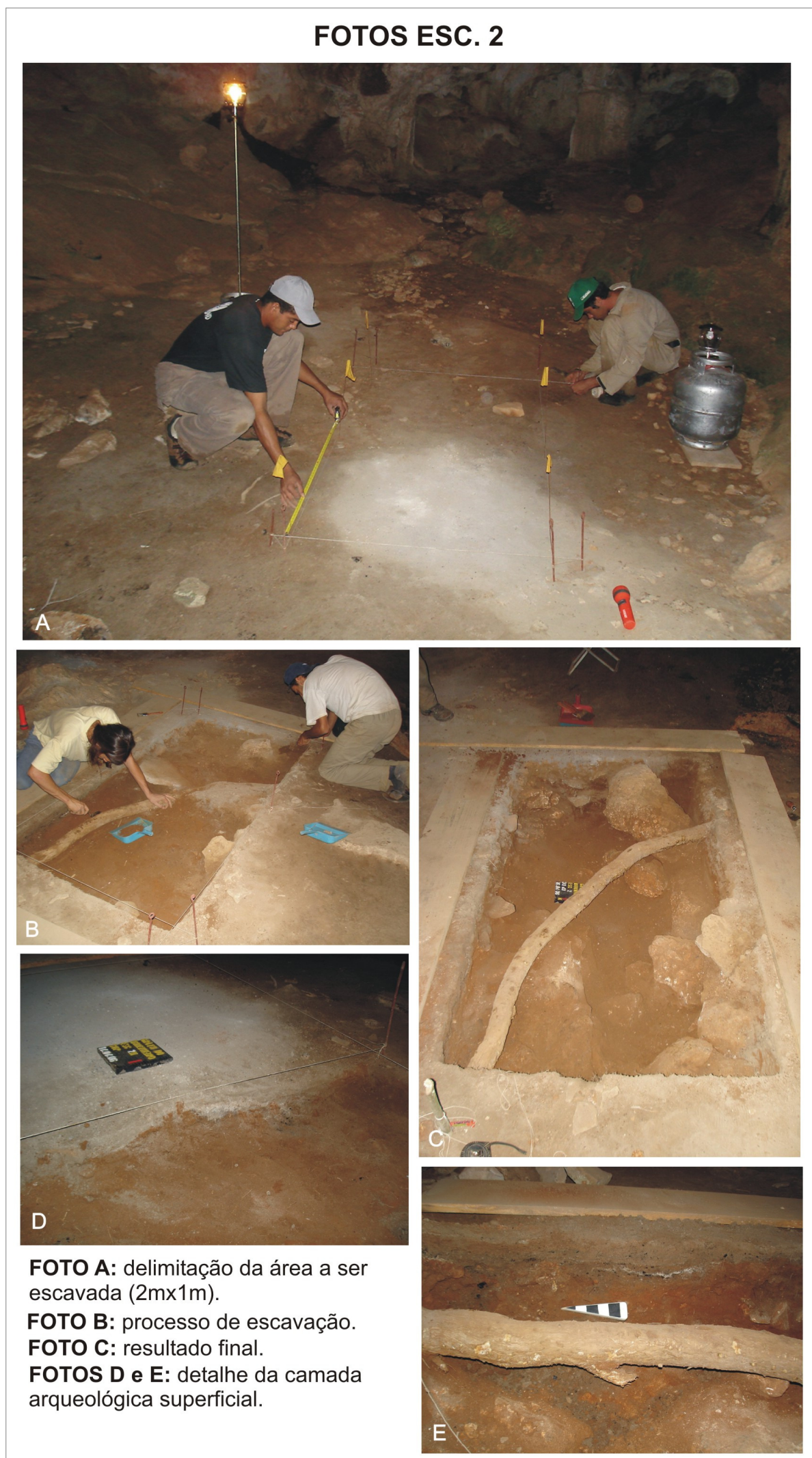


A Esc. 3, a escavação mais ampla e a única das três sujeita a chuvas, foi dividida em dois setores em função de um desnível (Norte e Sul), cada um cobrindo uma metade da trincheira. local, ao contrário das Escavações 1 e 2, não apresentava nenhuma estrutura superficial bem definida, como restos de fogueiras por exemplo. Acredita-se que os pacotes superiores foram erodidos, seguindo o declive natural do terreno, para dentro da caverna, assim expondo pacotes arqueológicos mais profundos, o que foi a razão pela escolha do local. Em área onde se identificou peças lascadas exumadas nas características pingueiras, procedeu-se à abertura de uma trincheira de $2 \mathrm{~m}$ por $5 \mathrm{~m}$, orientada para o NNW (ver planta baixa). Abaixo das pingueiras, abrangendo vários níveis arbitrários desde a superfície, foi encontrado uma rica indústria de pedra com um alto índice de descarte de artefatos formais. Além de 60 pontas de projétil ( $>75 \%$ preservadas) e os 11 fragmentos $(<75 \%)$ que foram abandonados no local, notou-se a presença de pré-formas, reveladoras das etapas da fabricação dessas peças bifaciais. Coletou-se ainda, além de uma grande quantidade de refugo, alguns raspadores unifaciais de tamanhos variados.

O Setor Esc. 3 - Sul foi escolhido para receber um maior detalhamento, apresentado no Capítulo V sobre o material lítico. Para o estudo tipológico uma primeira divisão foi realizada por matéria-prima. Em seguida separou-se o material lascado daquele encontrado bruto (34 plaquetas fragmentadas de quartzito). O material lascado foi, por sua vez, subdividido em instrumentos e refugo de lascamento:

- Instrumentos: esse tipo engloba peças retocadas inteiras ( $>75 \%$ preservados) e fragmentos de peças retocadas (<75\% preservados).

- Refugo: abrange todas as peças descartadas durante o processo de fabricação dos instrumentos ou exploração de núcleos: lascas, fragmentos de lascas, núcleos, fragmentos diversos e pré-formas de pontas de projétil.

A maior parte do material lascado do setor Esc. 3 - Sul, como dos outros dois, é constituído por refugo de lascamento, com 12537 peças, representando 99,5\% da amostra desse setor. Os instrumentos ou suportes retocados representam o restante da amostra $(0,5 \%)$ com 36 pontas de projétil inteiras, 12 fragmentos de ponta, 7 gumes bifaciais e 11 peças retocadas unifacialmente. 


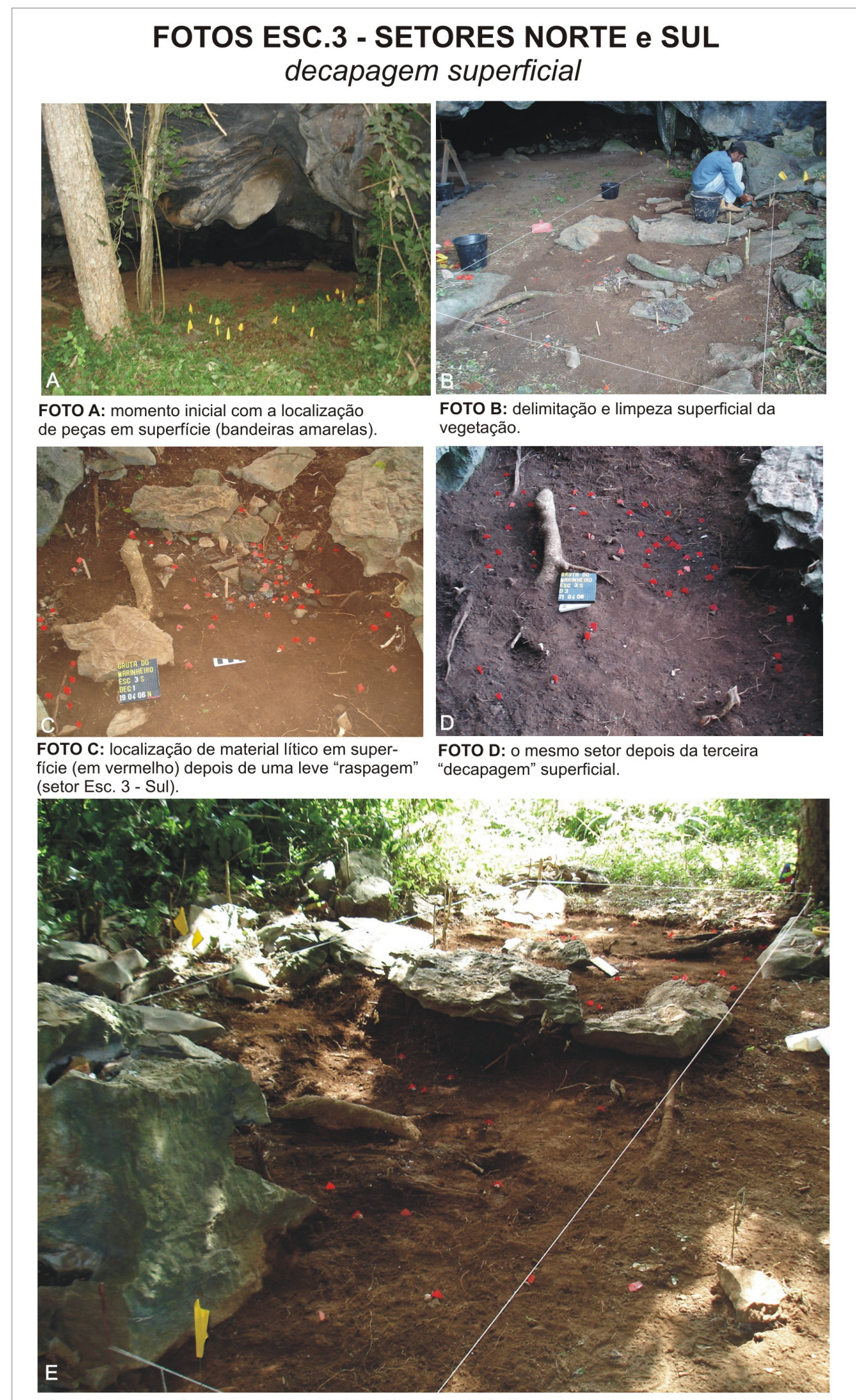

FOTO E: vista geral dos setores Esc. 3 - Sul e Norte depois da última decapagem e antes do início

da escavação por níveis arbitrários; as peças retiradas nas decapagens, pacote abrangendo cerca de $3 \mathrm{~cm}$ de espessura, foram plotadas em planta-baixa. 

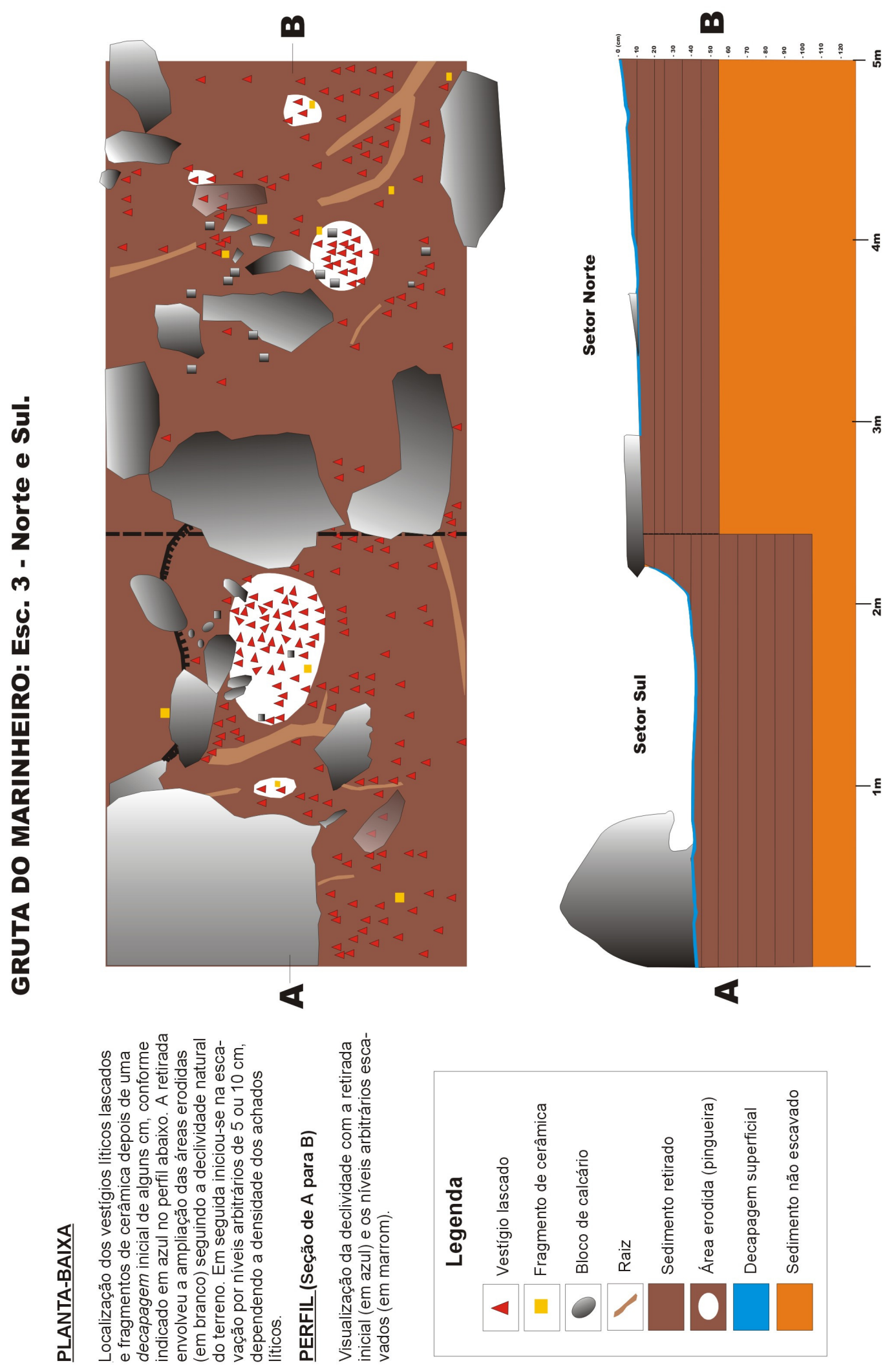


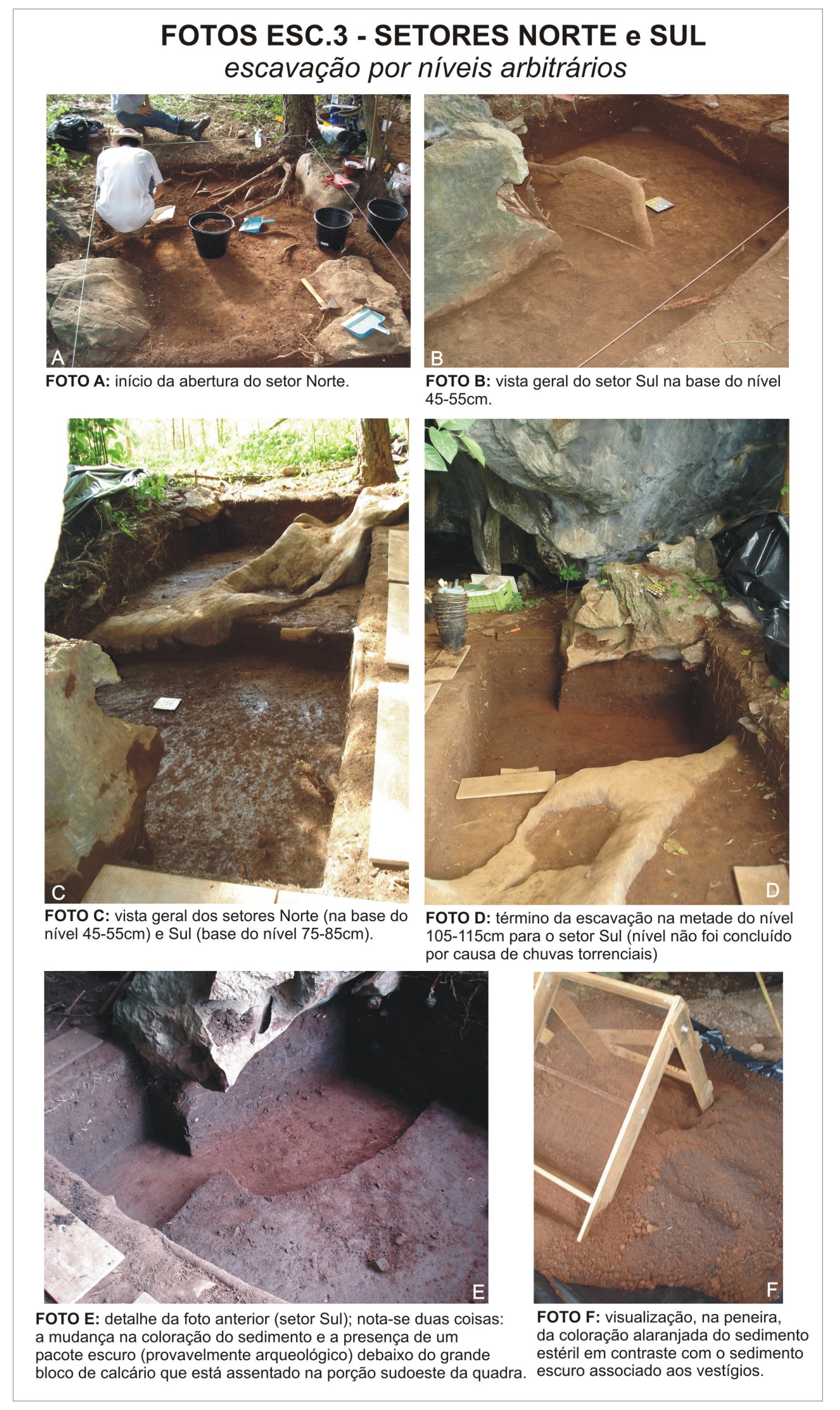


No setor Esc. 3 - Norte foram recuperadas 9031 peças (ou 27,8 kg), com 24 pontas de projétil inteiras, 6 fragmentos e 6 pré-formas, além de 3 peças retocadas unifacialmente. $A$ grande maioria, com 8982 peças, é constituído por refugo de lascamento. Dez fragmentos de plaqueta de quartzito também foram coletados nesse setor. Ao contrário da Esc. 3 - Sul, a escavação do setor norte ainda não atingiu o estéril, o que explica o aumento de peças no último nível escavado $(45-55 \mathrm{~cm})$ na figura abaixo. A amostra do primeiro nível escavado $(0-10 \mathrm{~cm})$ foi incorporado à decapagem superficial por ser uma amostra muito pequena (corresponde à retirada das partes mais altas da quadra para o nivelamento do piso).

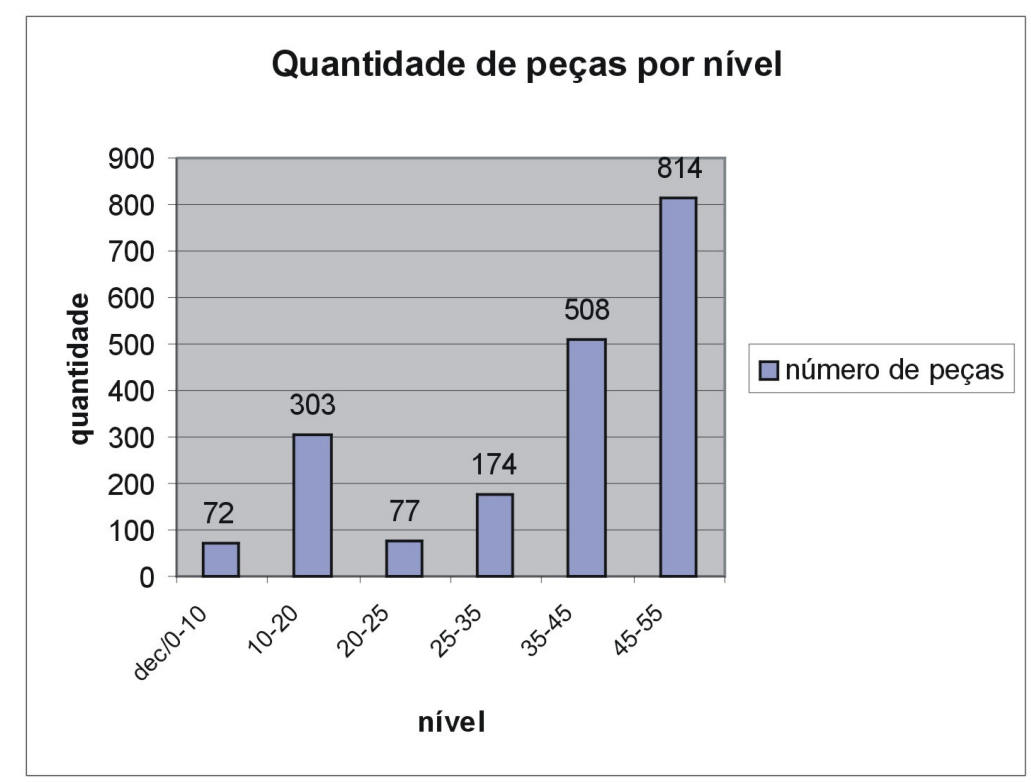

\section{3 - Céu Aberto.}

Um sítio a céu aberto, Lagoa do Retiro e 4 ocorrências isoladas entram nessa categoria: esses últimos são vestígios arqueológicos encontrados sem qualquer conexão com um sítio. Somente as peças retocadas foram coletadas.

Tabela: relação das ocorrências e os tipos de vestígios coletados nelas.

\begin{tabular}{llcc}
\hline \multicolumn{2}{c}{ OCORRÊNCIAS } & UTM & TIPO \\
\hline 14 & Próx. Abrigo Lagoa de Peixe I & 415358 E / 7753476 N & Raspador \\
15 & Brejão & 415598 E / 7750479 N & Raspador \\
16 & Barreado & 410943 E / 7749595 N & Ponta de Projétil \\
17 & Próxima Gruta Ninfeta & 435886 E / 7750850 S & Raspador \\
\hline
\end{tabular}




\section{CAPÍTULO 5- ANÁLISE DO MATERIAL LÍTICO}

A análise foi realizada em função dos critérios metodológicos descritos no Capítulo 1 que visam caracterizar o material lítico a partir de três principais elementos: tipologia, tecnologia e cronologia. A análise abrangeu 13 sítios e 4 ocorrências isoladas, com um maior peso para os três sítios, acima descritos, que receberam intervenções. A amostra total de lítico corresponde a 23904 peças, sendo que 96,8\% proveniente da Gruta do Marinheiro (23126 peças), 2,6\% da Loca do Suim (626 peças), 0,6\% do Abrigo Lagoa de Peixe I (152 peças) e menos de 0,1\% dos sítios restantes e ocorrências isoladas. No final do capítulo, os dados dos diferentes sítios foram utilizados para compor uma referência cronológica inicial para a indústria lítica da região (item $5.6)$.

\section{1 - As matérias-primas}

Seis grupos de matéria-prima foram identificados a partir de uma observação macroscópica da textura e cor: chert, quartzito, quartzo, calcário, silex diverso e argilitos/lateritas. Cada grupo, quando possível, foi descrito levando em consideração a distribuição das respectivas áreas fonte. A distância entre o sítio e a jazida pode revelar aspectos relacionados à locomoção ou às relações de troca e contato que poderiam ter existido na pré-história.

A utilização preferencial de certas matérias-primas para a produção de determinados tipos de instrumentos pode estar ligado à disponibilidade, mas também a outros fatores como à qualidade da matéria-prima ou à praticidade de sua morfologia para o processo de fabricação. A maior facilidade de produzir pontas de projétil a partir de delgadas plaquetas fragmentadas do que sobre lascas, por exemplo, será discutido no item 5.2 sobre o lítico do sítio Gruta de Marinheiro.

De uma maneira geral, as ferramentas tendem a ser de menores no momento em que se está mais longe da área fonte e aumenta a necessidade de um prolongamento da vida útil através da reavivagem de gumes gastos, principalmente quando não existe uma matéria-prima substituta equivalente no local de fácil obtenção. Essa estratégia produz instrumentos curados, com formas recorrentes, não necessariamente mais elaborados tecnicamente, mas que tiveram suas matérias-primas mais aproveitadas. Um exemplo disso na Província é a existência de pequenos plano-convexos de quartzito com até $5 \mathrm{~cm}$ de comprimento (ver foto abaixo). 


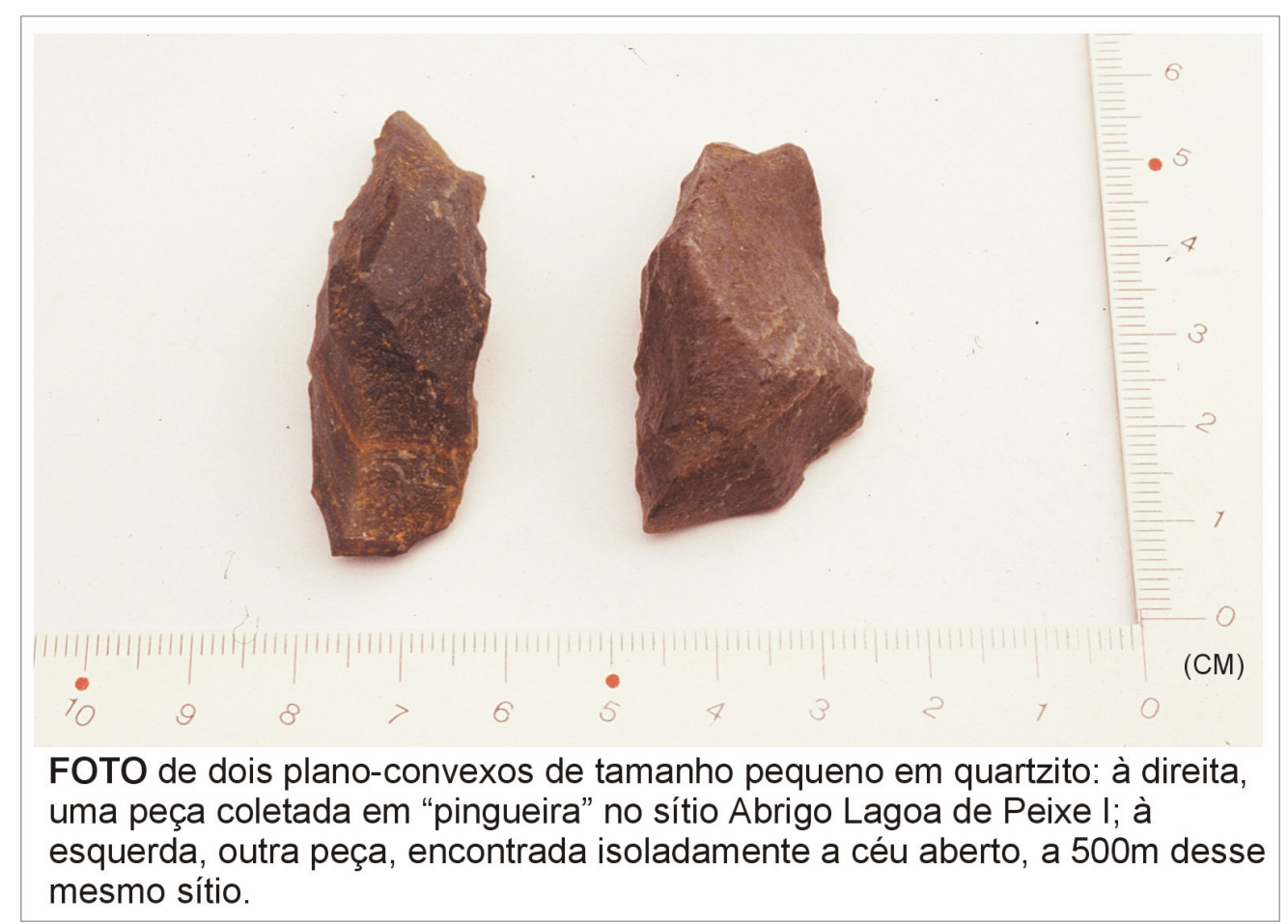

O quartzito, a preferida para a produção de pontas de projétil bifaciais, é uma matériaprima que aparece nas seqüências metassedimentares no limite sudoeste do carste, na Serra da Pimenta e no Morro do Diamante. A coloração (verde, marrom, preto, bege, azul,..) e textura (grãos mais ou menos finos) podem variar, assim como a forma (plaquetas, nódulos e seixos) em que são encontrados. Algumas cachoeiras visitadas pela equipe nos municípios de Pimenta e Santo Hilário apresentaram uma abundância dessa matéria-prima, principalmente da variedade verde.

O chert local, uma rocha sedimentar de cor predominantemente preta ${ }^{26}$, é encontrado associado ao calcário espalhado sobre praticamente toda região cárstica em formas e qualidades variadas (ver fotos abaixo). A variedade mais homogênea e silicificada (trata-se de silex ou flint propriamente dito) é a mais apropriada ao lascamento. $\mathrm{O}$ de qualidade inferior tende a se quebrar facilmente em plaquetas que frequentemente são encontradas nos sítios misturadas naturalmente ao solo. A grande diferença em termos de matéria-prima com a região cárstica de Lagoa Santa é exatamente a disponibilidade desse recurso endógeno, além do quartzo. Mais abundante que as outras matérias-primas ela foi utilizada de uma maneira generalizada pelos homens pré-históricos e é encontrada em todos sítios líticos pesquisados, geralmente em forma de refugo mas também como instrumentos, principalmente peças com gumes unifaciais.

\footnotetext{
${ }^{26}$ Foi provavelmente formada dos restos de esponjas marinhas antigas ou de outros animais que foram fossilizados.
} 


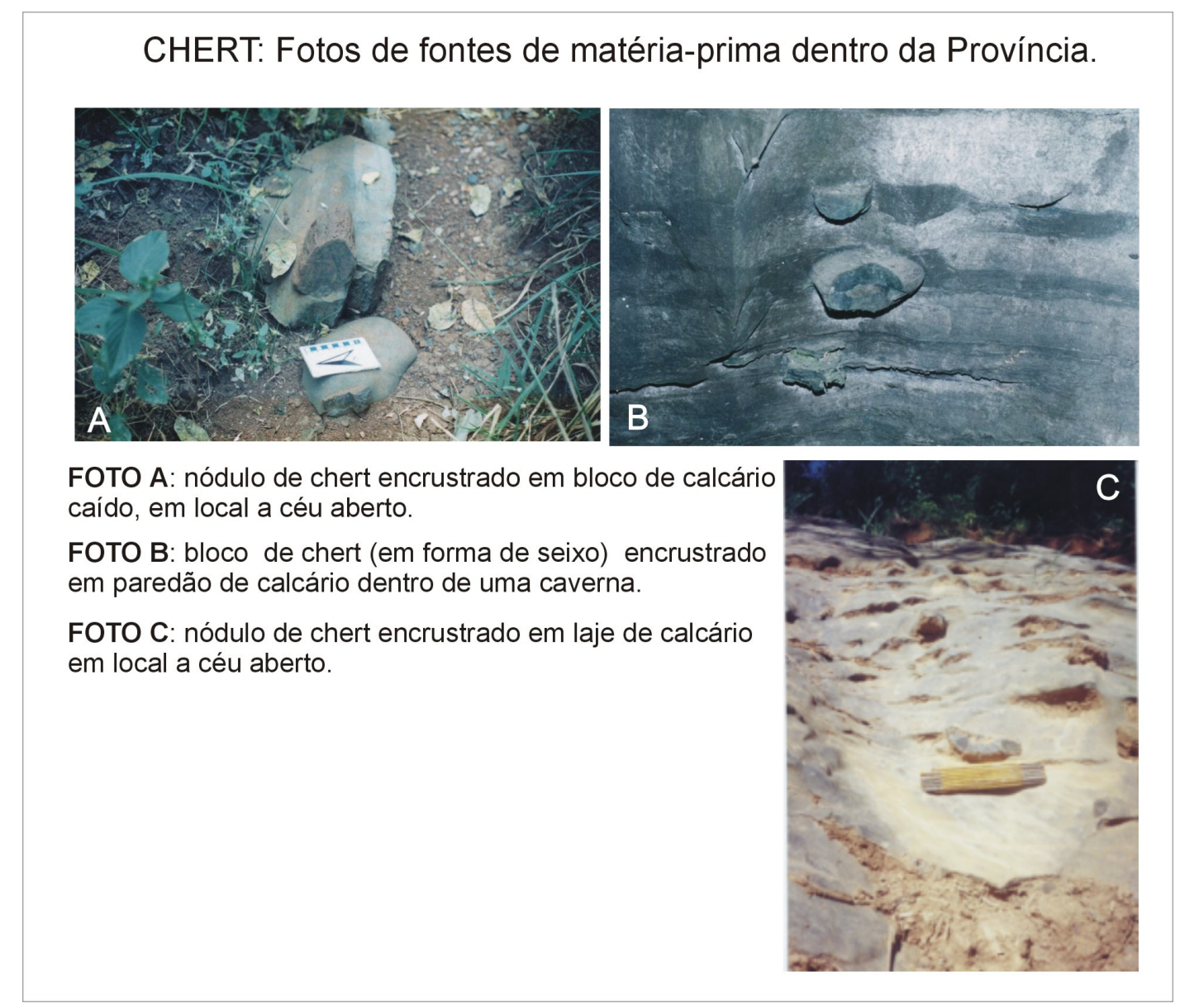

O quartzo, também bastante utilizado para a produção de pontas de projétil bifaciais, apresenta três variedades (quartzo hialino, translúcido e leitoso) e é encontrado em forma de prismas ou seixos relativamente pequenos, tanto dentro quanto na região do entorno do carste. Essa matéria-prima foi a única que apresentou marcas recorrentes de lascamento bipolar (além da unipolar). A utilização da percussão unipolar sobre as matérias-primas maiores e a bipolar sobre as com dimensões reduzidas (geralmente o quartzo, mas também a calcedônia), é uma característica recorrente em várias regiões do Brasil.

O calcário, apesar de ser uma matéria-prima pouco propícia ao lascamento, também foi lascada como demonstram algumas peças encontradas na Loca do Suim. Possivelmente estariam associadas à exploração do chert cujos blocos frequentemente apresentam um pedaço de calcário acoplado. Essa consideração parece razoável (mas não conclusiva) devido ao fato que nenhuma ferramenta (suporte retocado) de calcário foi identificada nos sítios estudados.

A categoria silex diverso tem uma presença discreta nos sítios e engloba variedades de silex cuja áreas fonte ainda não foram localizadas. Suspeita-se que têm uma origem exógena: uma hipótese foi levantada pelo geólogo Dr. Horn do Instituto de Geociências da Universidade Federal de Minas Gerais durante uma consulta informal de que a maioria das peças dessa 
categoria corresponderia a um silex associado a uma seqüência cretácea conhecida como "Mata da Corda", cuja presença mais próxima estaria na porção norte do município de Bambuí, a cerca de $70 \mathrm{~km}$ de Pains em linha reta.

Outra categoria menos freqüente é a argilitos/lateritas. Agrupado sob a mesma categoria no início da análise, as peças de argilito e laterita só depois, já próximo ao final do estudo, foram reconhecidas como sendo duas matérias-primas distintas (devido principalmente à coloração semelhante). A descoberta tardia não possibilitou a separação dessas duas e, portanto, foi mantido esse agrupamento. Ambas têm uma baixa densidade de peças: o argilito aparece em forma de refugo e uma ferramenta bifacial sobre plaqueta; a laterita, constituída só por refugo de lascamento, tem sua origem em blocos ferruginosos (algumas lascas apresentam córtex de nódulos). As áreas fontes das duas matérias-primas que comportam essa categoria ainda não foram localizadas.

Sabe-se, portanto, que a extração da matéria-prima ocorreu dentro da região cárstica e em áreas vizinhas. Nos três principais sítios existe uma recorrência de quatro grupos de matérias-primas: chert, quartzito, quartzo e silex diverso. Os argilitos/lateritas só foram identificadas na Gruta do Marinheiro e o calcário só na Loca do Suim.

A matéria-prima mais presente nos sítios em termos de volume, o chert, de qualidade variável, ocorre em várias localidades dentro do carste. A de melhor qualidade, mais silicificado e homogêneo é, entretanto, difícil de detectar: somente um nódulo de chert bem silicificado foi encontrado na região. (Faz. Massambará). Enquanto o chert foi preferido para a fabricação de peças unifaciais, o quartzito e o quartzo foram utilizados na produção de peças unifaciais e bifaciais.

Sabe-se que a alta mobilidade dos caçadores-coletores não permitia o transporte de um peso excessivo. Nesse sentido, acredita-se que as matérias-primas em geral ${ }^{27}$ foram transportadas como suportes em forma de lascas ou fragmentos de plaquetas para serem trabalhados outros locais. Essa visão é sustentada pelo fato de que nos sítios abrigados da Província não foram identificados núcleos pesados em superfície e nas escavações, nem de chert, encontrado em abundância na região, nem de qualquer outra matéria-prima. Por outro lado, lascas de debitagem, talhe e retoque de várias matérias-primas são bastante freqüentes nos sítios.

No Abrigo Lagoa de Peixe I encontrou-se mais lascas relacionadas à debitagem e com maior frequência de córtex para o silex preto do que para a principal matéria-prima exógena (quartzito). Essa está mais representada nas lascas de talhe e retoque de peças, ligadas aos estágios finais de acabamento e de reutilização.

\footnotetext{
${ }^{27}$ Principalmente as matérias-primas que podem apresentar núcleos maiores como quartzito e chert.
} 


\section{2 - Gruta do Marinheiro}

A análise dos instrumentos abrangeu os três setores que forneceram vestígios líticos ${ }^{28}$ (a Escavação 2 não apresentou material). A análise do refugo de lascamento, por outro lado, se concentrou no setor Esc. 3 - Sul, correspondendo a 55\% da amostra proveniente desse sítio. Ver a figura abaixo que mostra a relação percentual da quantidade de material lítico coletado na Gruta do Marinheiro nos setores Esc. 1, Esc. 3 - Sul e Esc.3 - Norte.

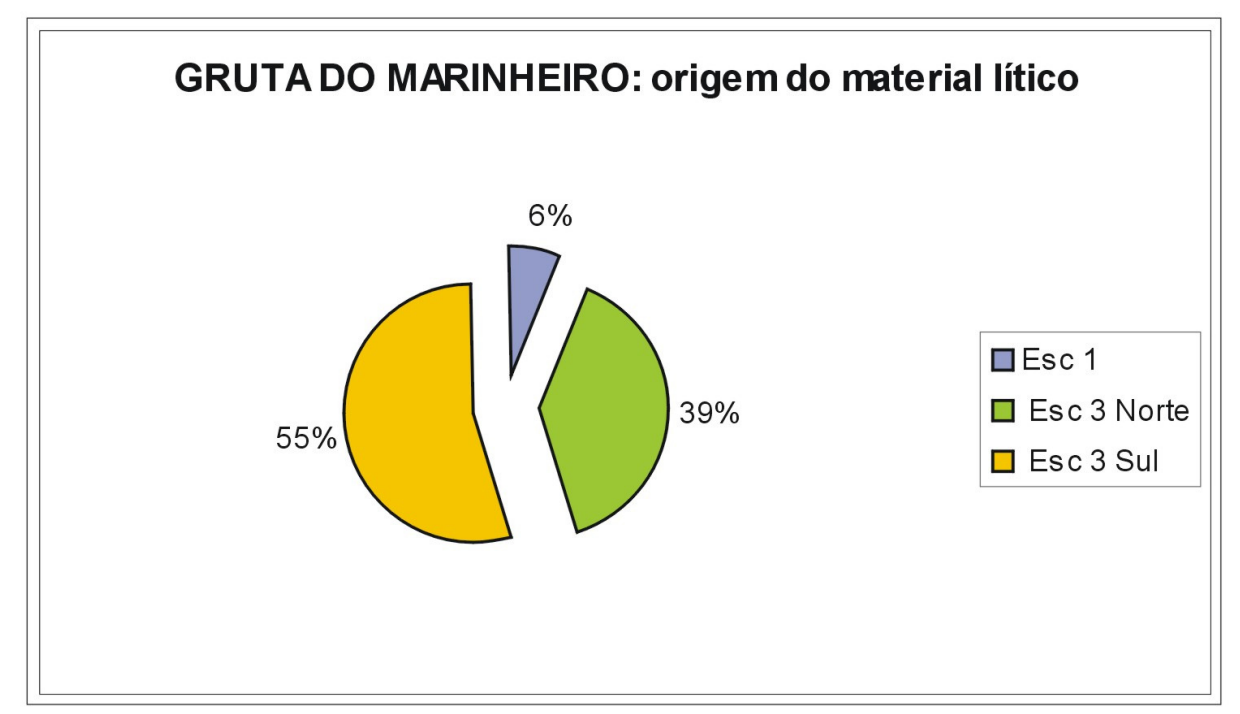

${ }^{28}$ Com exceção da análise cronológica dos instrumentos que se restringiu ao setor Esc. 3 -Sul. 


\subsection{1 - Análise tecno-tipológica do material lítico.}

\subsubsection{1 - Instrumentos:}

Os 81 instrumentos inteiros e 18 fragmentos associados aos níveis pré-cerâmicos são suportes talhados a partir de lascas ou plaquetas de diversas matérias-primas e apresentam gumes retocados que podem, pela forma observada, atender a funções como raspar, cortar e furar. A categoria de instrumentos foi subdividida em dois grandes grupos a partir de características ligadas ao processo de lascamento: peças unifaciais (14 unidades) e bifaciais (67 unidades). A ponta de projétil representa $74 \%$ dos instrumentos inteiros recuperados nas escavações da Gruta do Marinheiro, com 60 peças.

As peças unifaciais apresentam somente em uma das duas faces negativos de retiradas e são frequentemente chamados de "raspadores", um nome com atribuição funcional induzida a partir da forma das peças (apesar de também poderem ter sido utilizadas como facas). Essa categoria, envolvendo raspadores de formas e tamanhos variados, é representada por dois principais tipos, separados em função da área trabalhada e da localização dos gumes retocados.

O primeiro subgrupo (5 peças) de instrumentos unifaciais são raspadores laterais com um lascamento limitado a retoques em uma borda ou extremidade da peça.

O segundo subgrupo (9 peças) apresenta um lascamento ao longo de toda borda do suporte, com formas que variam de circular, trapezoidal a comprida; essa última se aproxima mais às formas dos típicos plano-convexos.

A forma alongada ou comprida é representada por cinco (5) peças, caracterizadas por terem um comprimento, em média, duas vezes o tamanho da largura (não preservaram o talão nem o bulbo em três dos cinco casos). Os suportes utilizados foram lascas de quartzito, chert, silex diverso e quartzo. O comprimento variou entre $3,8 \mathrm{~cm}$ e $8,3 \mathrm{~cm}$. Nas peças mais compridas foram identificados resquícios de córtex de seixo de quartzito e de plaqueta de chert. As peças menores (até $5 \mathrm{~cm}$ ) não apresentaram córtex nas suas faces externas, provavelmente devido à retirada desse durante o processo de reavivagem.

Foi realizado a medição do comprimento dos negativos em 10 peças unifaciais proveniente desse sítio. Concluiu-se que a fabricação dessas peças - com debitagem, talhe e retoque - produziu micro-lascas $(<1 \mathrm{~cm})$, lascas pequenas $(>1 \mathrm{~cm} \mathrm{e}<2,5 \mathrm{~cm})$ e médias $(>2,5 \mathrm{~cm} \mathrm{e}$ $<4 \mathrm{~cm}$ ). Enquanto os negativos pequenos predominam, os negativos maiores que $4 \mathrm{~cm}$, que caracterizariam as lascas grandes, são raros. 


\section{GRUTA DO MARINHEIRO}

Instrumentos unifaciais trabalhados ao longo de toda borda.
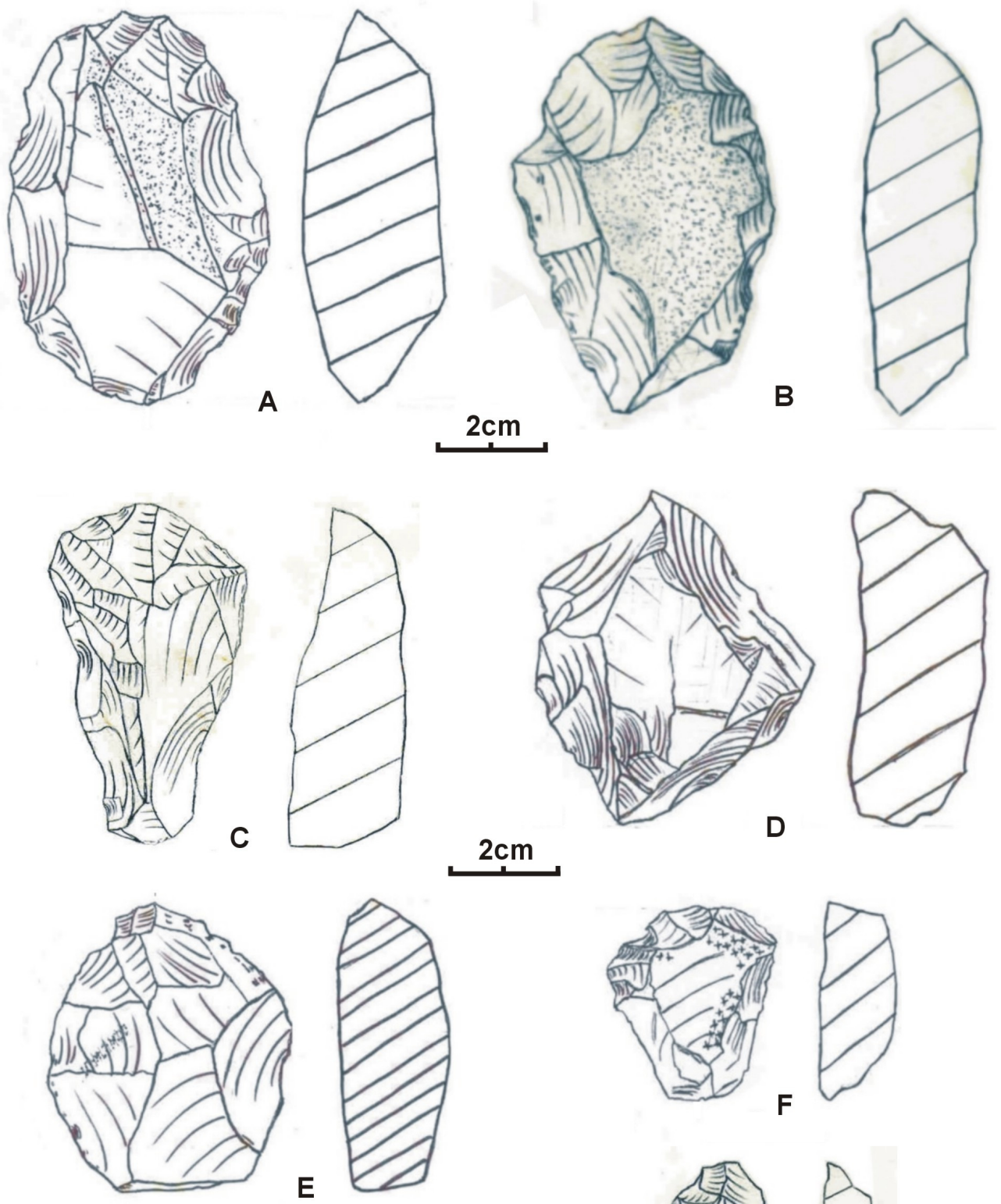

$2 \mathrm{~cm}$

D
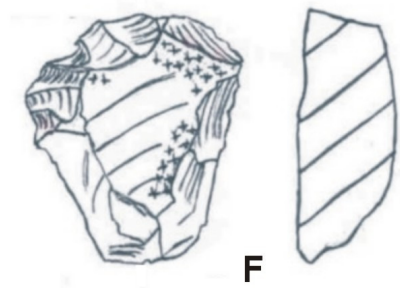

\section{FIGURA:}

A - Peça tipo "plano-convexo" sobre lasca de chert (NP=2360), parcialmente encoberto por córtex na face externa (ver pontilhado).

B - Peça retocada sobre lasca de quartzito com córtex de seixo na face externa $(\mathrm{NP}=3715)$.

C - Sobre lasca de silex diverso sem córtex (NP=2333).

D - Sobre lasca de quartzito (sem córtex) de forma trapezoidal (NP=3734).

E - Sobre lasca de quartzito (sem córtex) de forma circular $(N P=2527$ )

F - Sobre laca de quartzito (sem córtex) de forma trapezoidal $(N P=2537$ ).

G - Sobre lasca de quartzo translúcido do tipo alongado (NP=3663).
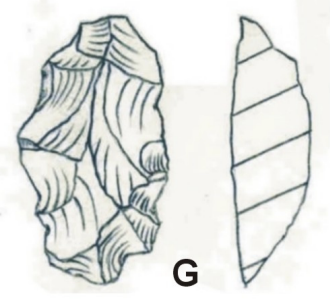


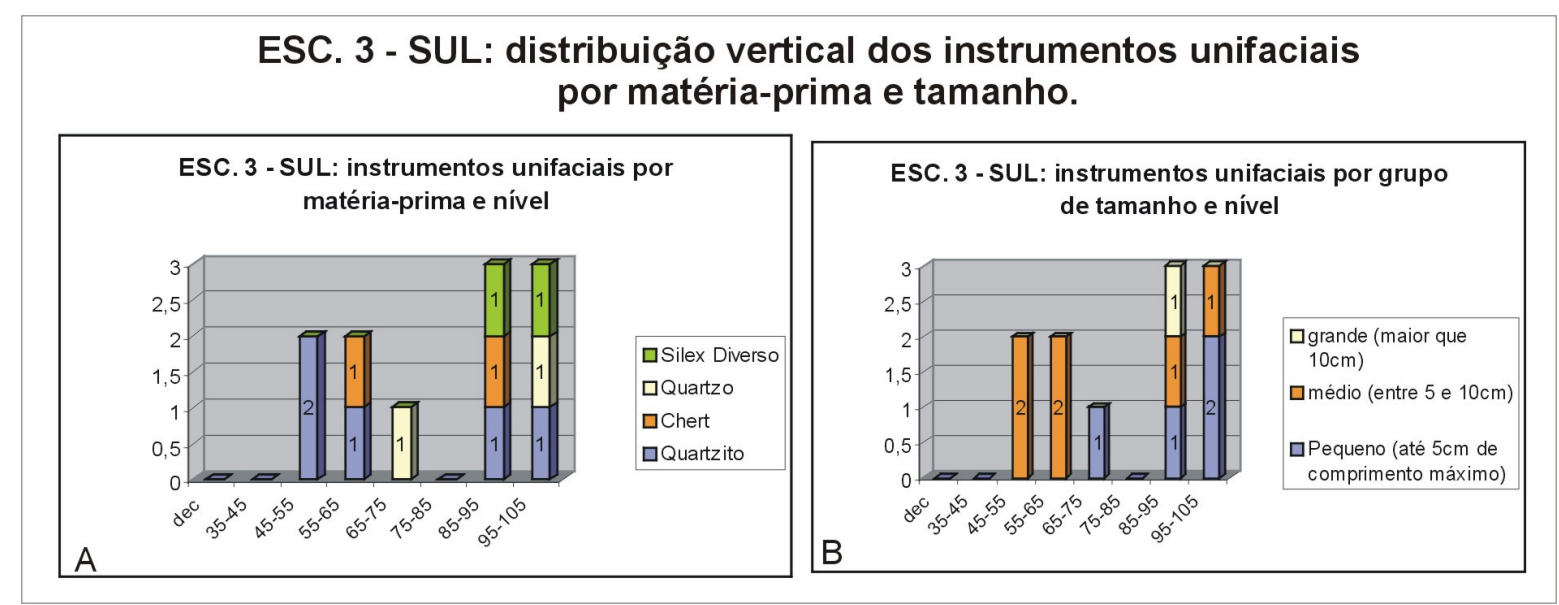

O característico da indústria da Gruta do Marinheiro é a predominância, em termos quantitativos, de instrumentos bifaciais. Trata-se de pontas de projétil, tanto sobre lascas quanto 0 sobre delgadas plaquetas de quartzito (13 peças), somando 60 peças. Essas, no entanto, não representam os únicos instrumentos bifaciais. Algumas plaquetas e lascas também foram retocadas bifacialmente (7 peças) para obtenção de um ou mais gumes cortantes, destacando-se uma sobre plaqueta de argilito (figura $A$ abaixo). Algumas peças compridas sobre plaquetas de quartzito podem também terem sidos utilizadas como facas (figuras $B$ e $C$ ), no entanto, somente pela forma a função não é tão óbvia de observar (talvez são "raspadores" bifaciais ou até pré-formas de pontas).

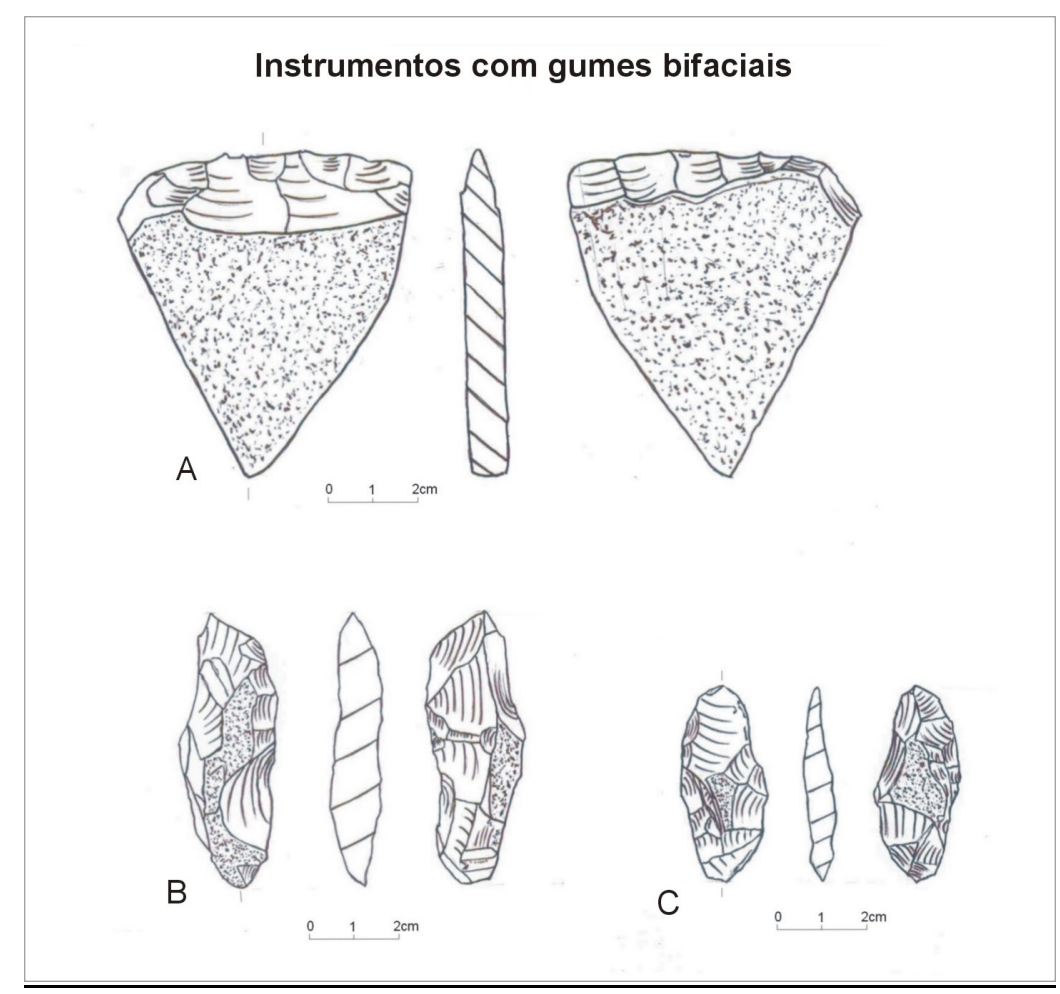




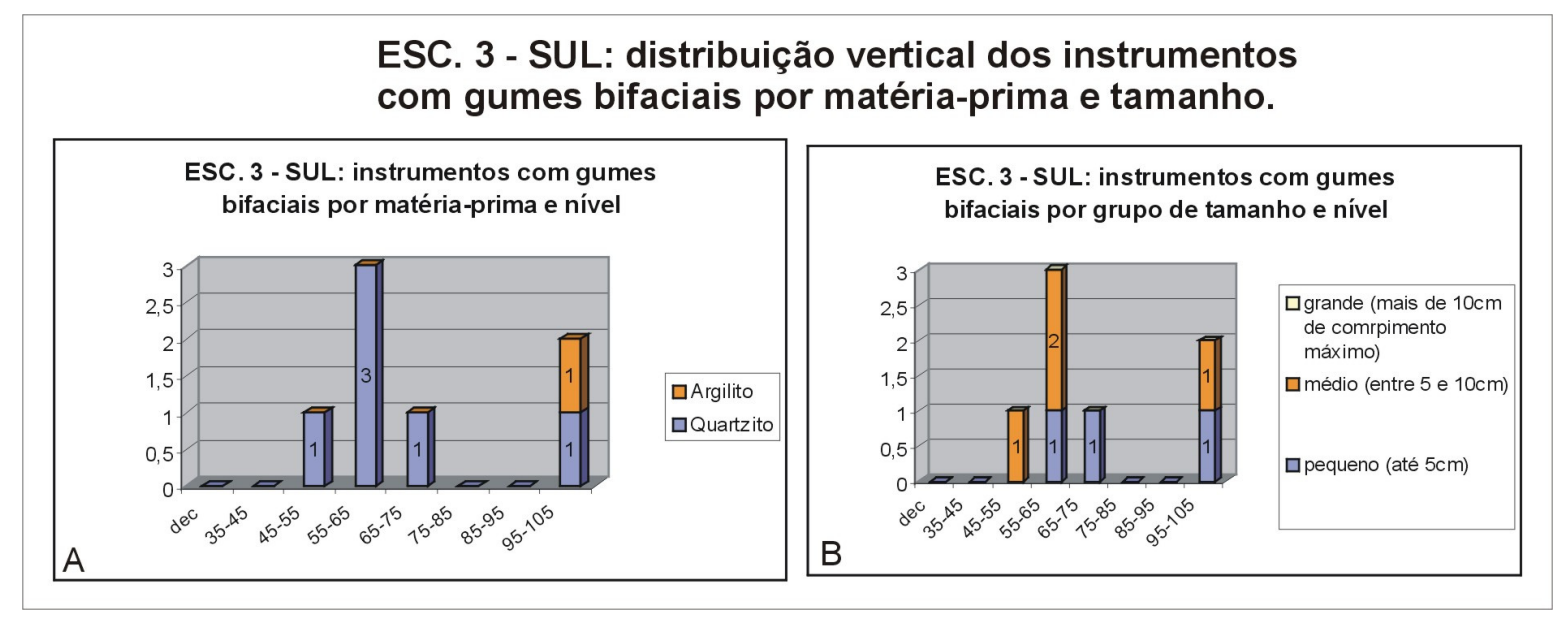

As etapas de fabricação podem também ser observadas em peças não acabadas, ou seja, a partir de pré-formas, relacionadas à modificação primária (DIAS, 1994:126-129) no processo de fabricação das pontas de projétil. Informações são obtidas a partir dessas pontas inacabadas que não podem mais ser observadas nas lascas inteiras. Em algum momento do processo o lascador desistiu em prosseguir porque a forma final desejada não pôde mais ser atingida devido a um acidente de lascamento ou erro de calculo na hora de escolher o suporte, por exemplo.

Tabela: relação das pré-formas.

\begin{tabular}{|c|c|c|c|c|c|c|c|c|c|}
\hline \multirow[t]{2}{*}{ NP } & \multirow[t]{2}{*}{ Setor } & \multirow[t]{2}{*}{ Nível } & \multirow[t]{2}{*}{ Matéria-prima } & \multirow[t]{2}{*}{ Suporte } & \multirow[t]{2}{*}{ Orientação } & \multicolumn{2}{|c|}{ Tecnologia } & \multicolumn{2}{|c|}{$\begin{array}{l}\text { Cicatrizes } 1^{\mathrm{a}} \\
\text { Modificação }\end{array}$} \\
\hline & & & & & & Unipolar & Bipolar & Forma & Extensão \\
\hline $2319-\mathrm{H}$ & Esc. 3 Norte & $35-45$ & Quartzito & Plaqueta & - & - & - & - & - \\
\hline 2311 & $\begin{array}{l}\text { Esc. 3- } \\
\text { Norte }\end{array}$ & $35-45$ & Quartzo & Lasca & Longitudinal & $x$ & & Concoidais & Moderadas \\
\hline 2314 & $\begin{array}{l}\text { Esc. } 3 \text { - } \\
\text { Norte }\end{array}$ & $35-45$ & Quartzo & Lasca & Longitudinal & $x$ & & Concoidais & Moderadas \\
\hline 2326 & $\begin{array}{l}\text { Esc. 3- } \\
\text { Norte }\end{array}$ & $45-55$ & Quartzito & Lasca & Proximal & $x$ & & Concoidais & Moderadas \\
\hline 2329 & $\begin{array}{l}\text { Esc. } 3 \text { - } \\
\text { Norte }\end{array}$ & $45-55$ & Quartzito & Lasca & Longitudinal & $X$ & & - & - \\
\hline 2336 & $\begin{array}{l}\text { Esc. } 3- \\
\text { Norte }\end{array}$ & $45-55$ & Quartzito & Plaqueta & - & $\mathrm{X}$ & & - & - \\
\hline $2356-C$ & Esc. 3 - Sul & $55-65$ & Silex diverso & Lasca & Proximal & $X$ & & - & - \\
\hline 3665 & Esc. 3 - Sul & $65-75$ & Quartzito & Lasca & Oblíquo & $X$ & & Oval & Invasora \\
\hline $2540-G$ & Esc. 3 - Sul & $65-75$ & Quartzo & Lasca & - & $x$ & & Concoidais & $\begin{array}{l}\text { Moderada } \\
\text { Invasora }\end{array}$ \\
\hline $2540-\mathrm{H}$ & Esc. 3-Sul & $65-75$ & Quartzito & Lasca & - & $X$ & & - & - \\
\hline 3688 & Esc. 3 - Sul & $75-85$ & Quartzito & Lasca & Proximal & $X$ & & - & - \\
\hline 3695 & Esc. 3 - Sul & $75-85$ & Quartzo hialino & Lasca & - & $x$ & & - & - \\
\hline 3717 & Esc. 3 - Sul & $85-95$ & Quartzito & Lasca & - & $X$ & & - & - \\
\hline 3690 & Esc. 3 - Sul & $75-85$ & Silex diverso & Lasca & - & $x$ & & - & - \\
\hline 3674 & Esc. 3 - Sul & $65-75$ & Quartzito & Lasca & Proximal & $X$ & & - & - \\
\hline $3710-A$ & Esc. 3 - Sul & $75-85$ & Quartzito & Lasca & Longitudinal & $X$ & & - & - \\
\hline
\end{tabular}

As pré-formas sobre lasca podem assumir quatro orientações, relacionando o eixo de percussão (observação de talão e bulbo) com o eixo longitudinal da pré-forma, ou seja, seu comprimento: longitudinal, distal, proximal ou oblíquo. Tipos de cicatrizes deixadas pela 
modificação primária e secundária: expandidas, concoidais, laminares, ovais e irregulares (esse último típicas da bipolaridade).

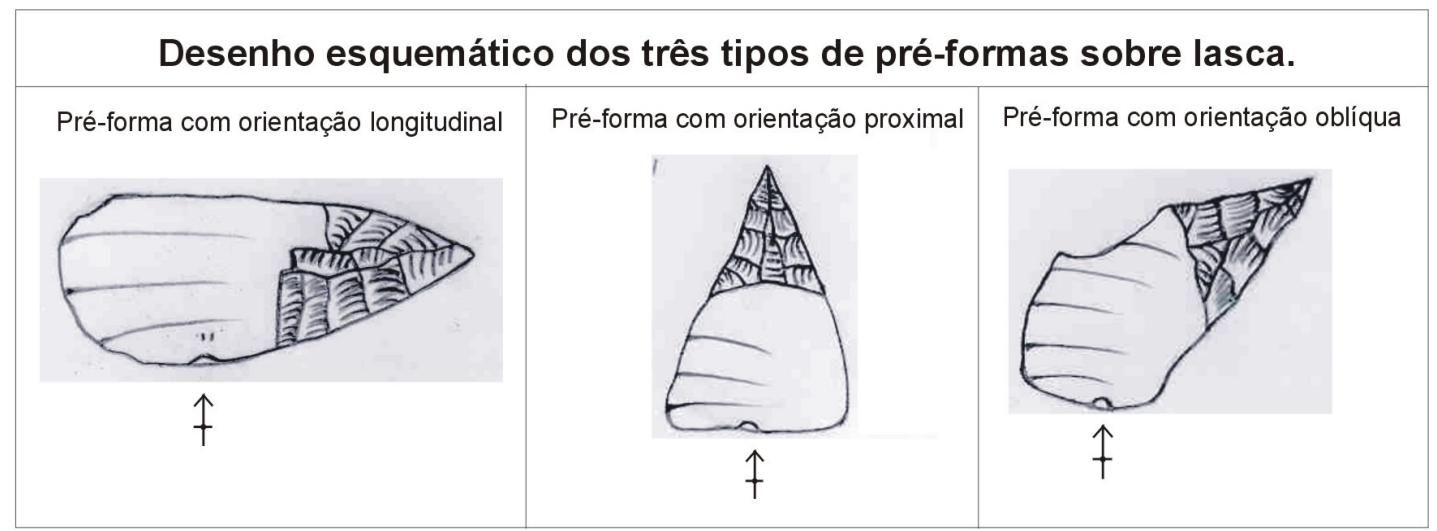

A escolha de plaquetas finas, como ocorreu para 13 pontas inteiras, diminui significativamente o trabalho de debitagem para a redução do volume. Outra vantagem da plaqueta sobre a lasca (como suporte) são as faces paralelas das plaquetas finas que facilitam a obtenção de uma ponta reta (sem ter que eliminar por meio de lascamento a curvatura que aparece nas lascas).

Foi realizado a medição do comprimento dos negativos em 10 pontas de projétil proveniente desse sítio. Concluiu-se que a fabricação dessas peças produziu predominantemente micro-lascas $(<1 \mathrm{~cm})$.

Inicialmente as peças inteiras e fragmentadas foram agrupadas por matéria-prima: 75 das 76 são de quartzito e quartzo (ver tabela).

Tabela: relação das pontas de projétil inteiras e fragmentadas por matéria-prima da Gruta do Marinheiro.

\begin{tabular}{lccccc}
\hline & Chert & Quartzito & Quartzo & Silex diverso & Total \\
\hline Pontas $(>75 \%)$ & 1 & 35 & 23 & 0 & $59^{\star}$ \\
Fragmentos de pontas $(<75 \%)$ & 0 & 10 & 6 & 1 & 17 \\
Total & 1 & 45 & 29 & 1 & 76 \\
\hline
\end{tabular}

${ }^{*}$ A superfície de uma peça estava alterada e tornou-se ilegível.

As pontas inteiras foram então dividias em três grupos de tamanho: pequenas $(<2,5 \mathrm{~cm})$, médias (entre 2,5 e $5 \mathrm{~cm}$ ) e grandes ( $>5 \mathrm{~cm}$ de comprimento). As diferenças na morfologia das pontas inteiras, que podiam estar expressando diferenças estilísticas, foram poucas, tanto horizontalmente quanto verticalmente, ou seja, ao longo do tempo não houve mudanças significativas nos tipos de pontas fabricadas. As pontas de tamanho médio com aletas obtusas $^{29}$, pedúnculos retos e convexos, de quartzito ou quartzo predominam.

${ }^{29}$ Aleta convexa ou com ligeira quebra formando um ângulo. 


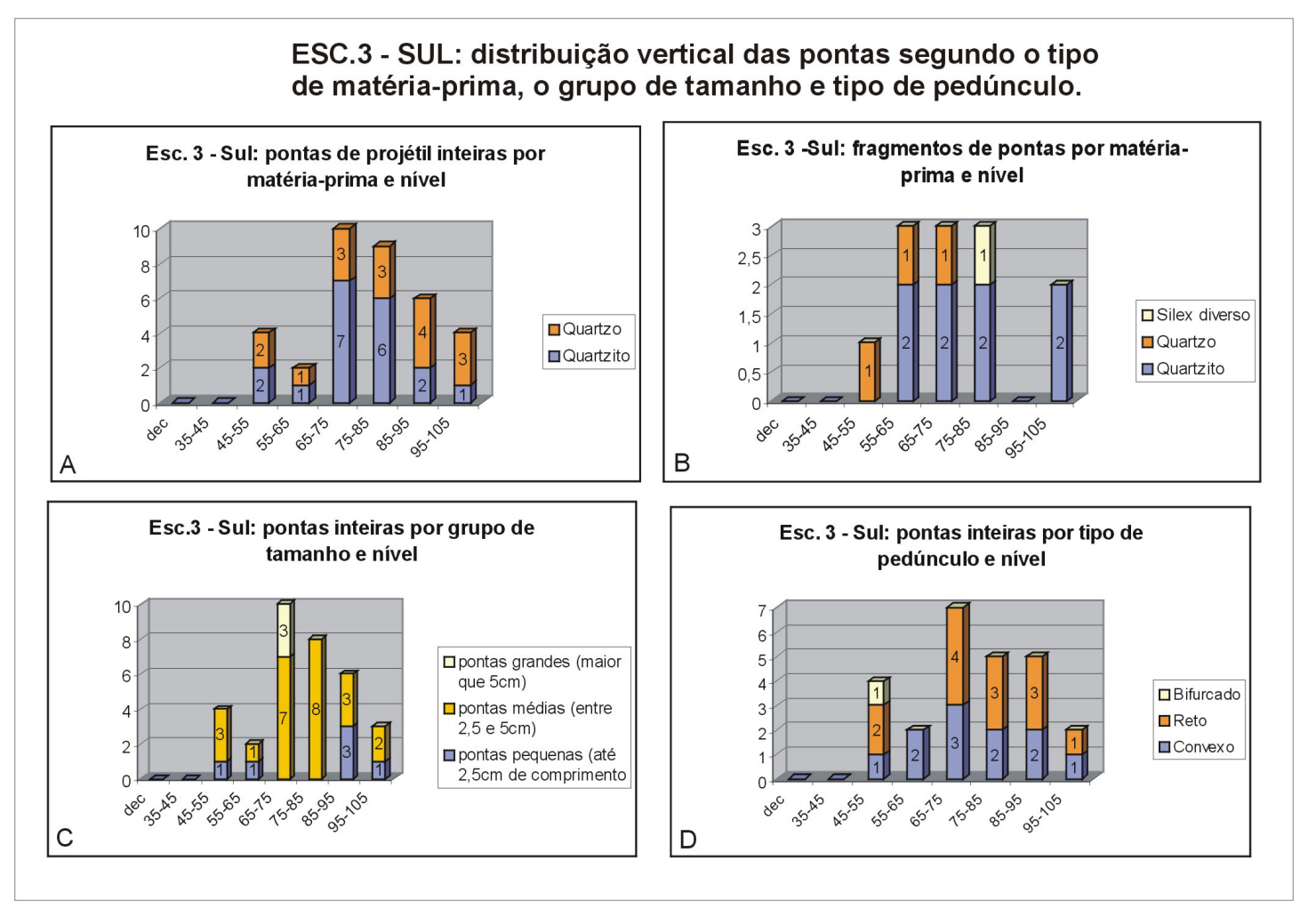




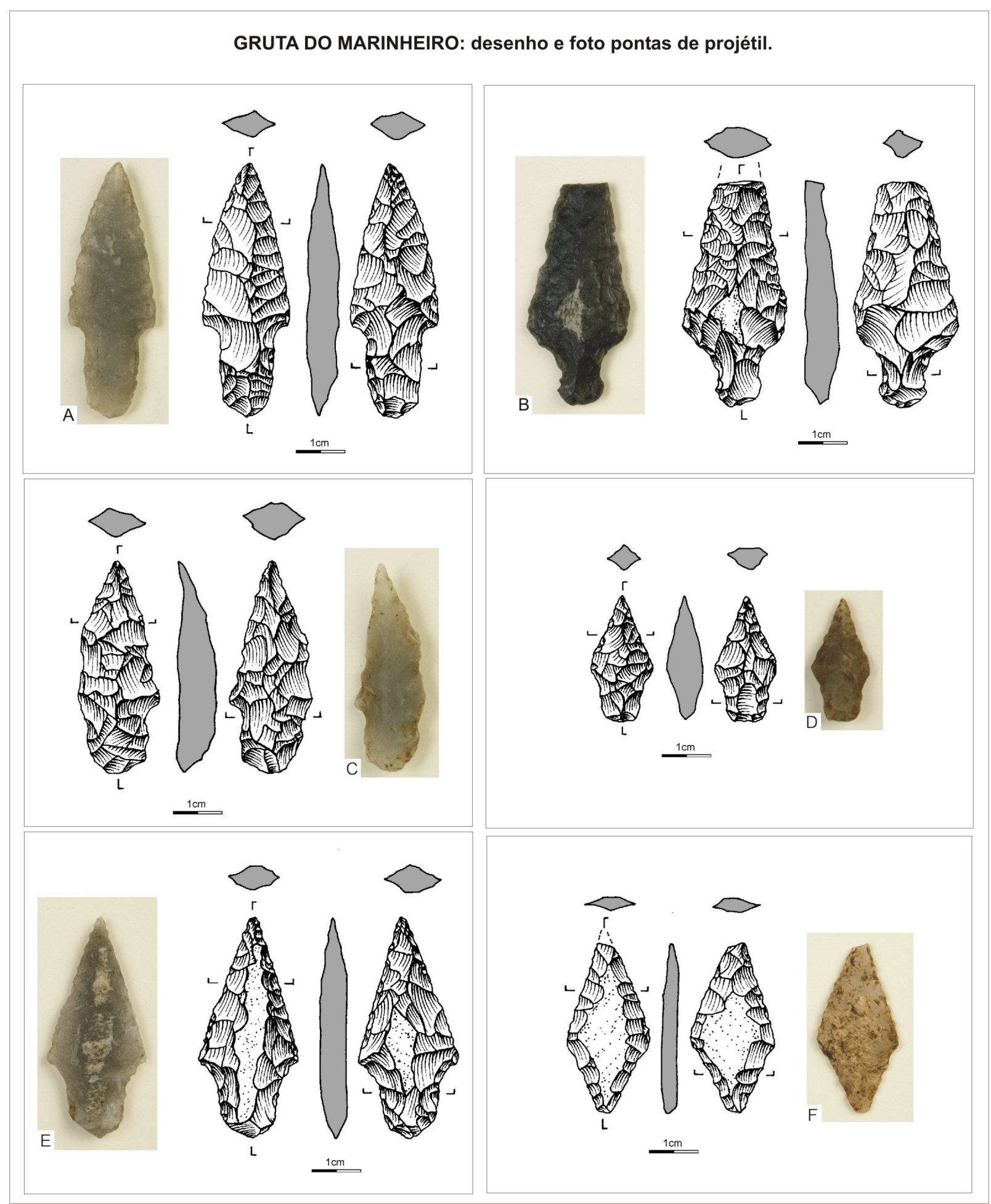




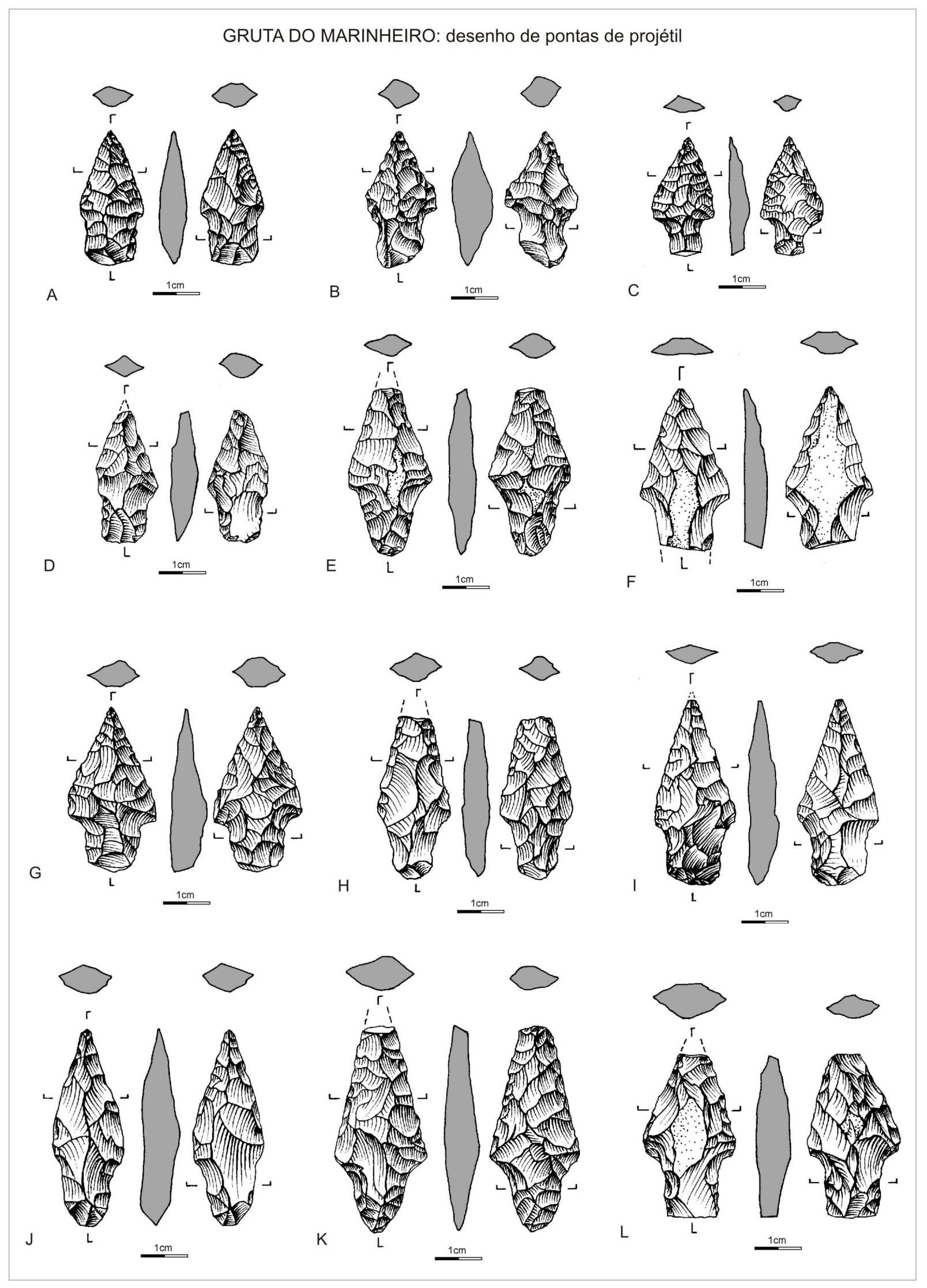




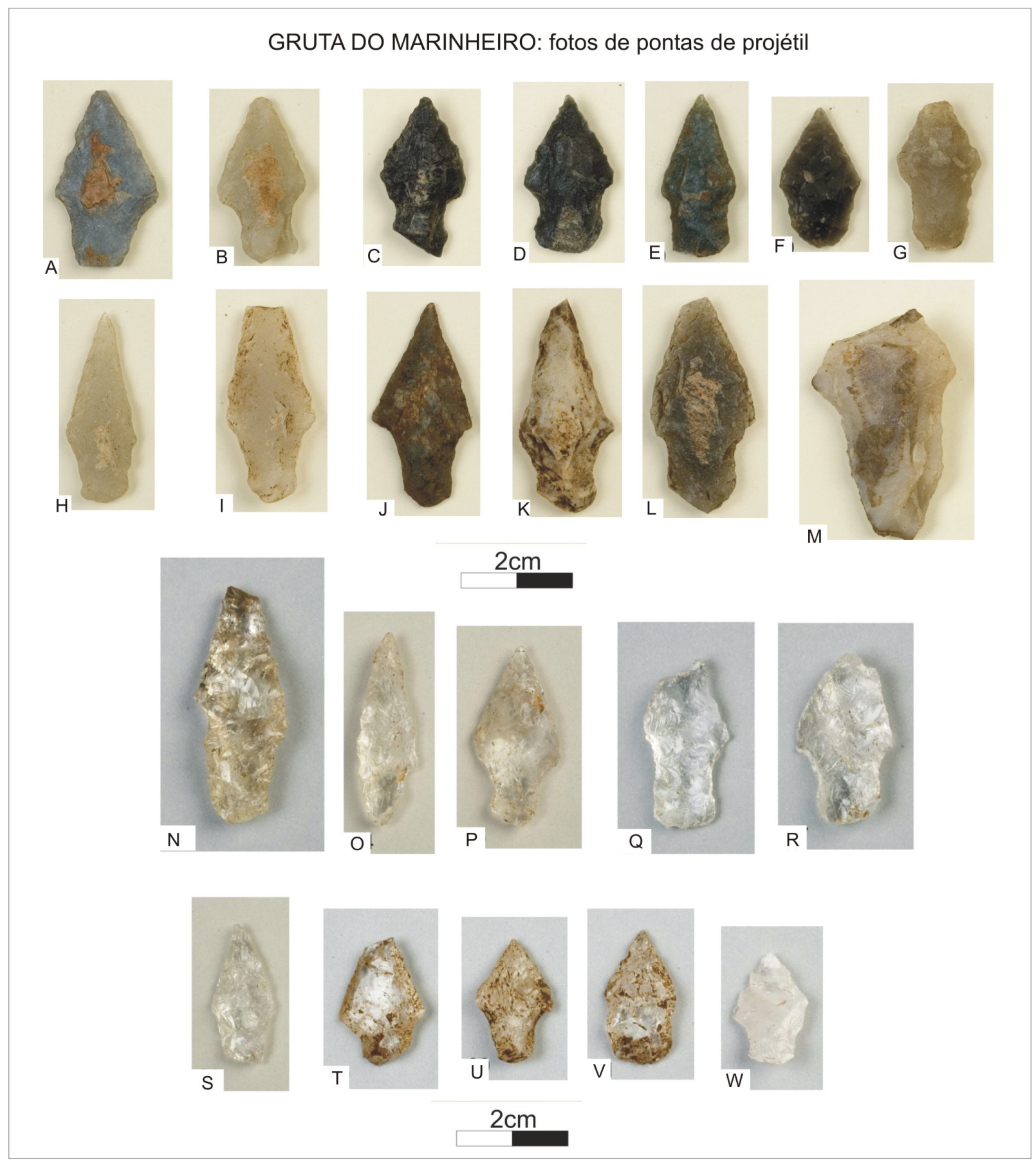


Tabela: Relação das pontas inteiras provenientes da Gruta do Marinheiro, com exceção de uma do Abrigo Lagoa do Retiro $\left(n^{\circ} 61\right)$ e outra ocorrência isolada da região do Barreado $\left(n^{\circ} 62\right)$.

\begin{tabular}{|c|c|c|c|c|c|c|c|c|c|c|c|}
\hline & NP & Setor & Nível & $\begin{array}{c}\text { Matéria- } \\
\text { prima }\end{array}$ & Suporte & $\begin{array}{c}\text { Comp. } \\
(\mathrm{cm})\end{array}$ & $\begin{array}{l}\text { Larg. } \\
\text { Máx. }\end{array}$ & $\begin{array}{l}\text { Esp. } \\
\text { Máx. }\end{array}$ & Pedúnculo & Aleta & $\begin{array}{c}\text { Integridade } \\
\text { estimada }\end{array}$ \\
\hline 1 & 2245 & Esc. 1 - Leste & $10-20$ & Quartzito & - & 4,9 (est.) & 2,57 & - & Convexo & Obtusa & $80 \%$ \\
\hline 2 & $2522-A$ & Esc. 3 - Norte & $10-20$ & Quartzito & - & 3,5 (est.) & 1,70 & 0,30 & - & Obtusa & $80 \%$ \\
\hline 3 & $2522-B$ & Esc. 3 - Norte & $10-20$ & Quartzito & - & 1,8 (est.) & 1,20 & 0,45 & Reto & Obtusa & $90 \%$ \\
\hline 4 & 2513 & Esc. 3 - Norte & $10-20$ & Quartzo & Lasca & 2,9 (est.) & 1,30 & 0,6 & - & Obtusa & $95 \%$ \\
\hline 5 & 2534 & Esc. 3-Norte & $20-25$ & Quartzito & - & 2,6 & 1,24 & 0,66 & Reto & $\begin{array}{l}\text { Obtusa - } \\
\text { circular }\end{array}$ & $100 \%$ \\
\hline 6 & 2303 & Esc. 3 - Norte & $25-35$ & Quartzito & Plaqueta & 3,6 (est.) & 1,70 & 0,24 & Apontado & Obtusa & $95 \%$ \\
\hline 7 & 2334 & Esc. 3 - Norte & $35-45$ & Quartzito & Lasca & 3,67 & 2,83 & 0,54 & Convexo & Obtusa & $100 \%$ \\
\hline 8 & 2315 & Esc. 3 - Norte & $35-45$ & Quartzito & Plaqueta & 4,55 & 2,00 & 0,46 & Convexo & Obtusa & $95 \%$ \\
\hline 9 & 2316 & Esc. 3 - Norte & $35-45$ & Quartzito & - & 2,90 & 1,33 & 0,46 & Reto & Obtusa & $100 \%$ \\
\hline 10 & 2317 & Esc. 3 - Norte & $35-45$ & Quartzo & Lasca & 2,42 & 1,07 & 0,40 & Reto & Obtusa & $90 \%$ \\
\hline 11 & $2319-A$ & Esc. 3 - Norte & $35-45$ & Quartzito & Lasca & 2,7 (est.) & 1,40 & 0,32 & Reto & Obtusa & $90 \%$ \\
\hline 12 & $2319-B$ & Esc. 3 - Norte & $35-45$ & Quartzo & Lasca & 3,13 & 1,50 & 0,60 & Convexo & Obtusa & $95 \%$ \\
\hline 13 & $2319-C$ & Esc. 3 - Norte & $35-45$ & Quartzito & Lasca & 2,7 (est.) & 1,45 & 0,56 & Convexo & Obtusa & $95 \%$ \\
\hline 14 & $2319-D$ & Esc. 3 - Norte & $35-45$ & Quartzito & Plaqueta & 3,3 & 1,20 & 0,47 & Convexo & Obtusa & $100 \%$ \\
\hline 15 & $2319-E$ & Esc. 3 - Norte & $35-45$ & Quartzo & Lasca & 3,4 & 1,10 & 0,56 & Convexo & - & $95 \%$ \\
\hline 16 & $2319-F$ & Esc. 3-Norte & $35-45$ & Quartzito & - & 2,2 (est.) & 1,55 & 0,55 & Convexo & Obtusa & $90 \%$ \\
\hline 17 & 2327 & Esc. 3 - Norte & $45-55$ & Quartzo & Lasca & 2,2 & 1,36 & 0,50 & Convexo & Obtusa & $100 \%$ \\
\hline 18 & 2330 & Esc. 3 - Norte & $45-55$ & Quartzito & Lasca & 4,1 (est.) & 1,54 & 0,50 & Convexo & Obtusa & $95 \%$ \\
\hline 19 & 2332 & Esc. 3 - Norte & $45-55$ & Quartzo & Lasca & 2,6 (est.) & 1,54 & 0,41 & - & Obtusa & $90 \%$ \\
\hline 20 & 2335 & Esc. 3-Norte & $45-55$ & Quartzito & Lasca & 2,7 (est.) & 1,43 & 0,36 & Reto & $\begin{array}{l}\text { Obtusa - } \\
\text { circular }\end{array}$ & $90 \%$ \\
\hline 21 & $2338-A$ & Esc. 3 - Norte & $45-55$ & Quartzito & Lasca & 2,9 (est.) & 1,30 & 0,4 & Convexo & $\begin{array}{l}\text { Obtusa - } \\
\text { circular }\end{array}$ & $95 \%$ \\
\hline 22 & 2341 & Esc. 3 - Norte & $45-55$ & Quartzo & Lasca & 2,38 & 1,27 & 0,46 & Reto & $\begin{array}{l}\text { Obtusa - } \\
\text { circular }\end{array}$ & $95 \%$ \\
\hline 23 & 2342 & Esc. 3-Norte & $45-55$ & Chert & Lasca & 2,5 & 1,46 & 0,55 & Convexo & Obtusa & $100 \%$ \\
\hline 24 & 2343 & Esc. 3 - Norte & $45-55$ & Quartzito & Plaqueta & 3,78 & 1,67 & 0,54 & Convexo & Obtusa & $95 \%$ \\
\hline 25 & 2523 & Esc. 3 - Sul & $45-55$ & Quartzo & Lasca & 2,4 (est.) & 1,40 & 0,54 & Convexo & Obtusa & $80 \%$ \\
\hline 26 & 2524 & Esc. 3 - Sul & $45-55$ & Quartzo & Lasca & 3,5 (est.) & 1,44 & 0,58 & Reto & Obtusa & $80 \%$ \\
\hline 27 & 2527 & Esc. 3 - Sul & $45-55$ & Quartzito & Lasca & 3,0 (est.) & 1,53 & 0,50 & Bifurcado & Obtusa & $95 \%$ \\
\hline 28 & 2533 & Esc. 3 - Sul & $45-55$ & Quartzito & Plaqueta & 3,16 & 1,84 & 0,38 & Reto & Obtusa & $95 \%$ \\
\hline 29 & 2344 & Esc. 3 - Sul & $55-65$ & Quartzito & Plaqueta & 4,1 (est.) & 1,87 & 0,52 & Convexo & Obtusa & $90 \%$ \\
\hline 30 & $2356-A$ & Esc. 3 - Sul & $55-65$ & Quartzo & Lasca & 2,3 & 1,10 & 0,50 & Convexo & $\begin{array}{l}\text { Obtusa - } \\
\text { circular }\end{array}$ & $100 \%$ \\
\hline 31 & $2540-A$ & Esc. 3 - Sul & $65-75$ & Quartzito & Plaqueta & 2,8 (est.) & 1,80 & 0,51 & - & Obtusa & $80 \%$ \\
\hline 32 & $2540-B$ & Esc. 3 - Sul & $65-75$ & Quartzito & Lasca & 2,9 (est.) & 1,53 & 0,59 & - & $\begin{array}{l}\text { Obtusa - } \\
\text { circular }\end{array}$ & $90 \%$ \\
\hline 33 & $2540-C$ & Esc. 3 - Sul & $65-75$ & Quartzito & Plaqueta & 5,7 (est.) & 2,30 & 0,60 & Convexo & $\begin{array}{l}\text { Obtusa - } \\
\text { circular }\end{array}$ & $90 \%$ \\
\hline 34 & 2542 & Esc. 3 - Sul & $65-75$ & Quartzito & Lasca & 5,23 & 1,79 & 0,54 & Convexo & Reta & $100 \%$ \\
\hline 35 & $2540-D$ & Esc. 3-Sul & $65-75$ & Quartzito & Plaqueta & 2,8 & 1,60 & 0,60 & Reto & Obtusa & $100 \%$ \\
\hline 36 & $2540-E$ & Esc. 3 - Sul & $65-75$ & Quartzo & Lasca & 3,2 (est.) & 1,80 & 0,70 & Reto & Obtusa & $80 \%$ \\
\hline 37 & 3666 & Esc. 3 - Sul & $65-75$ & Quartzo & Lasca & 3,1 (est.) & 1,50 & 0,40 & Reto & Obtusa & $75 \%$ \\
\hline 38 & 3661 & Esc. 3 - Sul & $65-75$ & Quartzo & Lasca & 3,56 & 1,90 & 0,69 & Reto & Reta & $100 \%$ \\
\hline 39 & $3675-A$ & Esc. 3 - Sul & $65-75$ & Quartzito & Lasca & 5,0 (est.) & 1,94 & 0,73 & Convexo & Obtusa & $90 \%$ \\
\hline 40 & $3675-B$ & Esc. 3 - Sul & $65-75$ & Quartzito & Lasca & 3,4 (est.) & 1,66 & 0,42 & - & Obtusa & $90 \%$ \\
\hline 41 & 3693 & Esc. 3 - Sul & $75-85$ & Quartzito & Plaqueta & 4,0 (est.) & 1,76 & 0,5 & Convexo & Obtusa & $90 \%$ \\
\hline 42 & 3686 & Esc. 3 - Sul & $75-85$ & Quartzo & Lasca & 2,59 & 1,59 & 0,8 & Reto & Obtusa & $98 \%$ \\
\hline 43 & 3691 & Esc. 3-Sul & $75-85$ & Quartzito & Lasca & 3,93 & 1,5 & 0,64 & Reto & Obtusa & $100 \%$ \\
\hline 44 & 3692 & Esc. 3 - Sul & $75-85$ & Quartzito & Lasca & 4,22 & 1,58 & 0,72 & Convexo & Obtusa & $100 \%$ \\
\hline 45 & 3699 & Esc. 3 - Sul & $75-85$ & Quartzo & Lasca & 2,8 (est.) & 1,35 & 0,38 & - & Obtusa & $90 \%$ \\
\hline
\end{tabular}




\begin{tabular}{|c|c|c|c|c|c|c|c|c|c|c|c|}
\hline 46 & 3700 & Esc. 3 - Sul & $75-85$ & $\begin{array}{l}\text { Quartzo } \\
\text { leitoso }\end{array}$ & Lasca & 2,9 & 1,8 & 0,68 & Reto & Obtusa & $100 \%$ \\
\hline 47 & 3702 & Esc. 3 - Sul & $75-85$ & Quartzito & Plaqueta & 2,8 (est.) & 1,67 & 0,3 & - & Obtusa & $90 \%$ \\
\hline 48 & 3703 & Esc. 3 - Sul & $75-85$ & Quartzito & Plaqueta & - & 2,0 & 0,6 & - & $\begin{array}{l}\text { Obtusa- } \\
\text { circular }\end{array}$ & $80 \%$ \\
\hline 49 & 3705 & Esc. 3 - Sul & $75-85$ & Quartzito & Plaqueta & 3,2 (est.) & 1,88 & 0,42 & - & Obtusa & $90 \%$ \\
\hline 50 & 3718 & Esc. 3 - Sul & $85-95$ & $\begin{array}{l}\text { Quartzo } \\
\text { hialino }\end{array}$ & Lasca & 2,2 (est.) & 1,37 & 0,44 & - & Obtusa & $90 \%$ \\
\hline 51 & 3722 & Esc. 3 - Sul & $85-95$ & $\begin{array}{l}\text { Quartzo } \\
\text { hialino }\end{array}$ & Lasca & - & 1,76 & 0,47 & - & Obtusa & $75 \%$ \\
\hline 52 & 3726 & Esc. 3 - Sul & $85-95$ & Quartzito & Lasca & 3,4 (est.) & 1,64 & 0,64 & Reto & Obtusa & $95 \%$ \\
\hline 53 & 3727 & Esc. 3 - Sul & $85-95$ & $\begin{array}{l}\text { Quartzo } \\
\text { leitoso }\end{array}$ & Lasca & 3,0 (est.) & 1,28 & 0,55 & Reto & Obtusa & $95 \%$ \\
\hline 54 & 3728 & Esc. 3 - Sul & $85-95$ & $?$ & Lasca & 2,22 & 1,14 & 0,29 & Reto & Ausente & $100 \%$ \\
\hline 55 & 3723 & Esc. 3 - Sul & $85-95$ & Quartzito & Lasca & 4,0 & 1,83 & 0,56 & Convexo & Obtusa & $98 \%$ \\
\hline 56 & 3730 & Esc. 3 - Sul & $85-95$ & Quartzo & Lasca & 2,1 & 1,4 & 0,4 & Convexo & Obtusa & $95 \%$ \\
\hline 57 & 3735 & Esc. 3 - Sul & $95-105$ & $\begin{array}{l}\text { Quartzo } \\
\text { hialino }\end{array}$ & Lasca & 3,0 (est.) & 1,5 & 0,8 & - & - & $95 \%$ \\
\hline 58 & 3743 & Esc. 3 - Sul & $95-105$ & Quartzito & Lasca & 2,35 & 1,5 & 0,56 & - & $\begin{array}{l}\text { Obtusa- } \\
\text { circular }\end{array}$ & $95 \%$ \\
\hline 59 & 3748 & Esc. 3 - Sul & $95-105$ & $\begin{array}{l}\text { Quartzo } \\
\text { hialino }\end{array}$ & Lasca & 3,2 & 1,14 & 0,45 & Convexo & Ausente & $100 \%$ \\
\hline 60 & 3749 & Esc. 3 - Sul & $95-105$ & $\begin{array}{l}\text { Quartzo } \\
\text { hialino }\end{array}$ & Lasca & - & 1,94 & 0,69 & Reto & $\begin{array}{l}\text { Obtusa- } \\
\text { circular }\end{array}$ & $80 \%$ \\
\hline 61 & 1067 & - & Sup. & Quartzo & Lasca & 4,15 & 2,33 & 0,53 & Reto & - & $80 \%$ \\
\hline 62 & 1191 & - & Sup. & Quartzito & Lasca & 5,4 & 2,5 & 0,98 & Reto & Obtusa & $95 \%$ \\
\hline
\end{tabular}

Tabela: Relação das pontas fragmentadas.

\begin{tabular}{|c|c|c|c|c|c|c|}
\hline & NP & Setor & Nível & Matéria-prima & Suporte & Tipo \\
\hline 1 & $2319-G$ & Esc. 3 - Norte & $35-45$ & Quartzo & - & Ponta \\
\hline 2 & 2311 & Esc. 3 - Norte & $35-45$ & Quartzo & lasca & Prox. - mesial \\
\hline 2 & 2312 & Esc. 3 - Norte & $35-45$ & Quartzito & - & Pedúnculo e parte mesial \\
\hline 3 & 2331 & Esc. 3 - Norte & $45-55$ & Quartzo & - & Pedúnculo e parte mesia \\
\hline 4 & $2338-B$ & Esc. 3 - Norte & $45-55$ & Quartzito & Plaqueta & Pedúnculo \\
\hline 5 & $2338-C$ & Esc. 3 - Norte & $45-55$ & Quartzito & - & Ponta \\
\hline 6 & 2536 & Esc. 3 - Sul & $45-55$ & Quartzo & - & Parte mesial \\
\hline 7 & $2356-B$ & Esc. 3 - Sul & $55-65$ & Quartzito & Plaqueta & Mesial \\
\hline 8 & 2359 & Esc. 3 - Sul & $55-65$ & Quartzo & - & Parte mesial \\
\hline 9 & $2540-F$ & Esc. 3 - Sul & $65-75$ & Quartzo & - & Ponta \\
\hline 10 & 3664 & Esc. 3 - Sul & $65-75$ & Quartzito & Plaqueta & Pedúnculo \\
\hline 11 & 3662 & Esc. 3 - Sul & $65-75$ & Quartzito & - & Parte mesial \\
\hline 12 & 3750 & Esc. $3-$ Sul & $95-105$ & Quartzito & Lasca & Pedúnculo \\
\hline 13 & 3701 & Esc. 3 - Sul & $75-85$ & Silex diverso & Lasca & Parte mesial e ponta \\
\hline
\end{tabular}




\begin{tabular}{ccccccc}
\hline 14 & 3704 & Esc. 3 - Sul & $75-85$ & Quartzito & Lasca & $\begin{array}{c}\text { Pedúnculo e parte mesial } \\
15\end{array}$ \\
& 3744 & Esc. 3 - Sul & $95-105$ & Quartzito & Plaqueta & $\begin{array}{c}\text { Parte mesial e distal } \\
\text { (ponta) }\end{array}$ \\
16 & 2537 & Esc. 3 - Sul & $55-65$ & Quartzito & Lasca & Parte distal (ponta) \\
17 & $3710-\mathrm{B}$ & Esc. 3 - Sul & $75-85$ & Quartzito & Lasca & Parte proximal \\
\hline
\end{tabular}

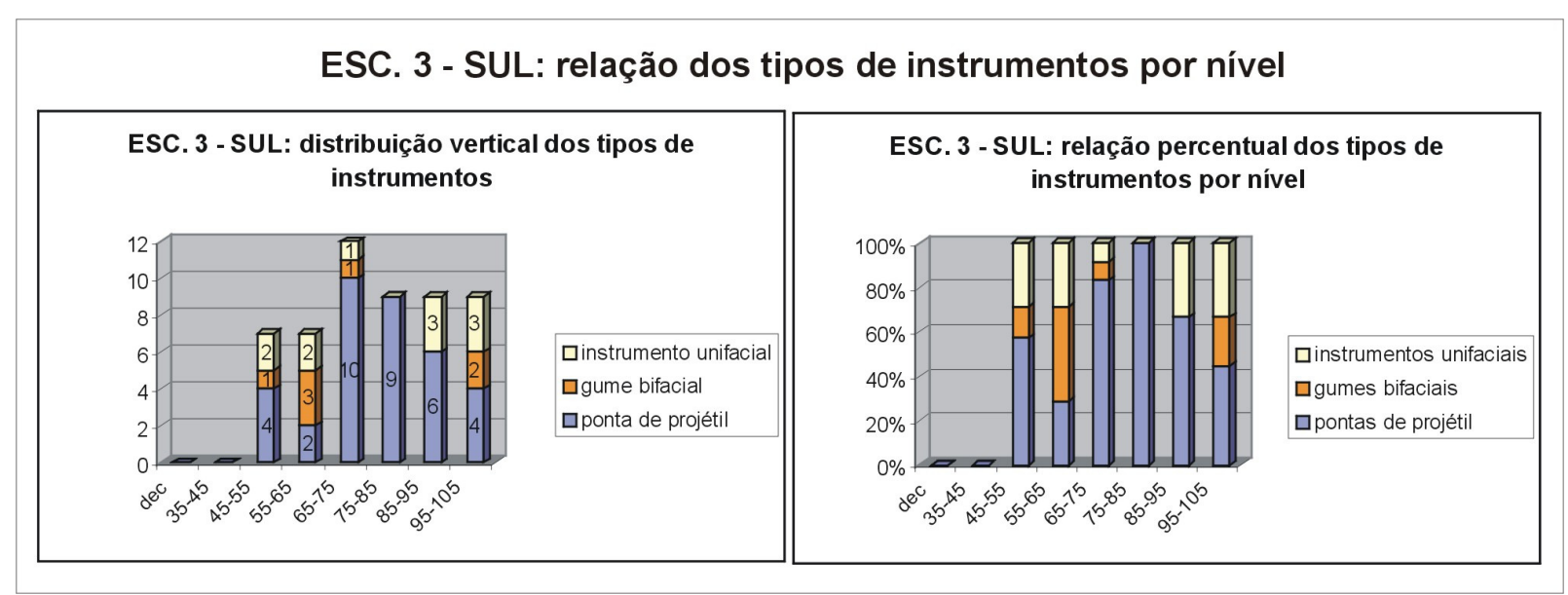

5.2.1.2 - Refugo da Esc.3 - Sul:

Uma análise aprofundada de todo refugo encontrado no sítio Gruta do Marinheiro, envolvendo mais de 22 mil peças, estava além das possibilidades (em tempo e recursos financeiros) do presente mestrado ${ }^{30}$. Decidiu-se escolher um dos quatro setores escavados (Esc. 3 - Sul) para uma triagem mais detalhada, enquanto os setores restantes tiveram suas peças apenas quantificadas e pesadas por matéria-prima (descrito no Capítulo IV sobre os sítios). Das quatro áreas escavadas, a Esc. 3 - Sul foi a que atingiu a maior profundidade, com um pacote arqueológico de $70 \mathrm{~cm}$ de espessura; foi também a que apresentou o maior número de peças e a única com níveis datados $(55-65 \mathrm{~cm}$ e $95-105 \mathrm{~cm})$. Acredita-se que a amostra desse setor seja representativa também para o Esc.3 - Norte, em se tratando de duas áreas contíguas na entrada da caverna (também pela semelhança geral entre as duas amostras líticas). Os outros dois setores (Esc. 1 e 2) se encontram a uma certa distância da Esc. 3, em partes totalmente abrigadas no interior da cavidade natural, e apresentam diferenças mais marcantes em termos da variabilidade lítica (em relação ao Esc. 3). O setor Esc. 1 tem uma amostra lítica significativa, porém apresenta apenas um instrumento (uma ponta de projétil), em contraste com a Esc. 3, Norte e Sul, que juntos têm mais de 80 peças retocadas; o Esc. 2, por sua vez, não forneceu uma amostra lítica. 
O refugo do setor selecionado, o Esc. 3 - Sul, com 12537 peças (incluindo 10 préformas) ou $31,4 \mathrm{~kg}$, foi inicialmente agrupado, por nível, em 5 grande grupos de matéria-prima: chert, quartzito, quartzo, silex diverso e argilitos/lateritas (não havia calcário lascado). A figura A abaixo mostra a quantidade de peças por matéria-prima; a figura $B$ apresenta a distribuição delas por nível. Constata-se que os diferentes tipos de matérias-primas identificados estão presentes em todos os níveis (com exceção dos argilitos/lateritas); a variação está na quantidade de peças por nível. A baixa densidade no nível $35-45 \mathrm{~cm}$ se deve ao fato de se tratar do primeiro nível arbitrário escavado depois da decapagem superficial (o nivelamento do piso no início da escavação, com a retirada do sedimento apenas nos cantos mais altos da quadra, resultou em uma amostra bem menor). Uma menor quantidade de peças também foi retirada na decapagem (dec) por se tratar de uma camada com apenas $3 \mathrm{~cm}$ de espessura (e não os $10 \mathrm{~cm}$ que os níveis arbitrários têm).

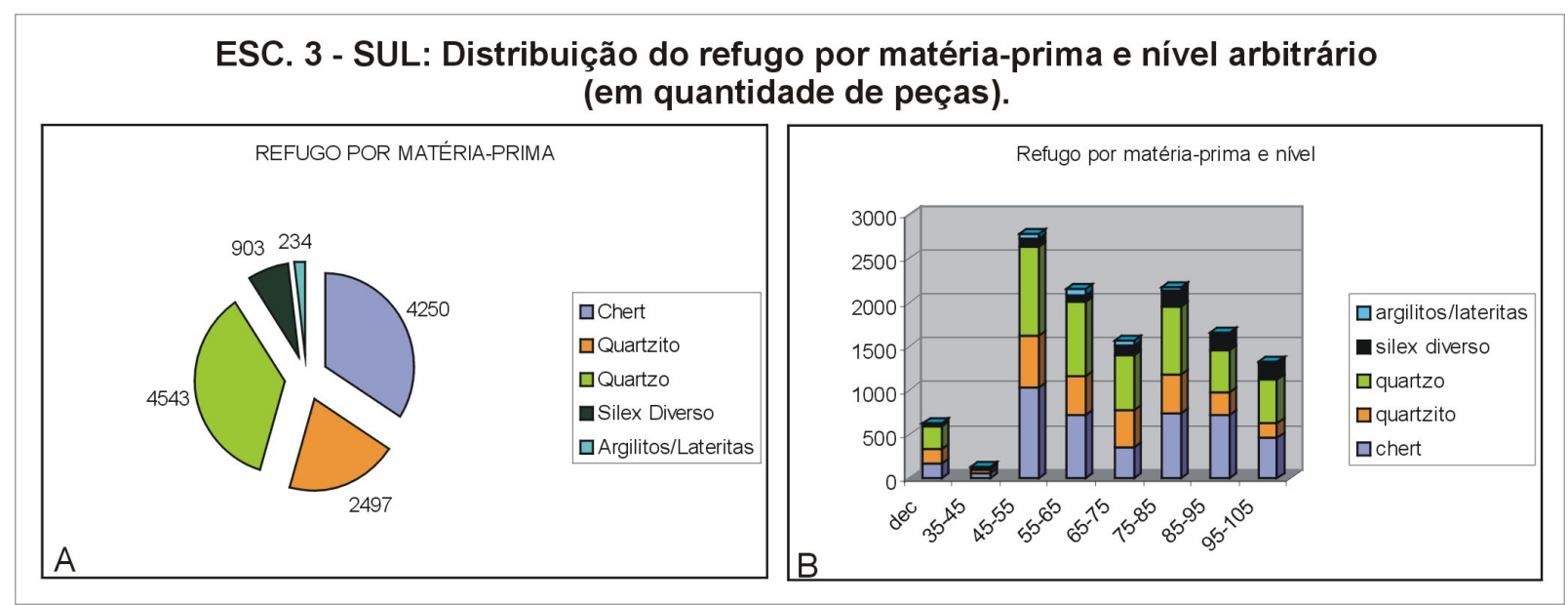

Dentro de cada grupo de matéria-prima foi realizado uma separação envolvendo quatro principais categorias tipológicas: lascas inteiras, fragmentos de lasca, núcleos e fragmentos diversos. Como ocorreu com as matérias-primas, observou-se uma relativa constância qualitativa e uma variação quantitativa entre os níveis escavados (ver figuras abaixo).

\footnotetext{
${ }^{30}$ Não foi realizada uma análise individual de todo refugo.
} 


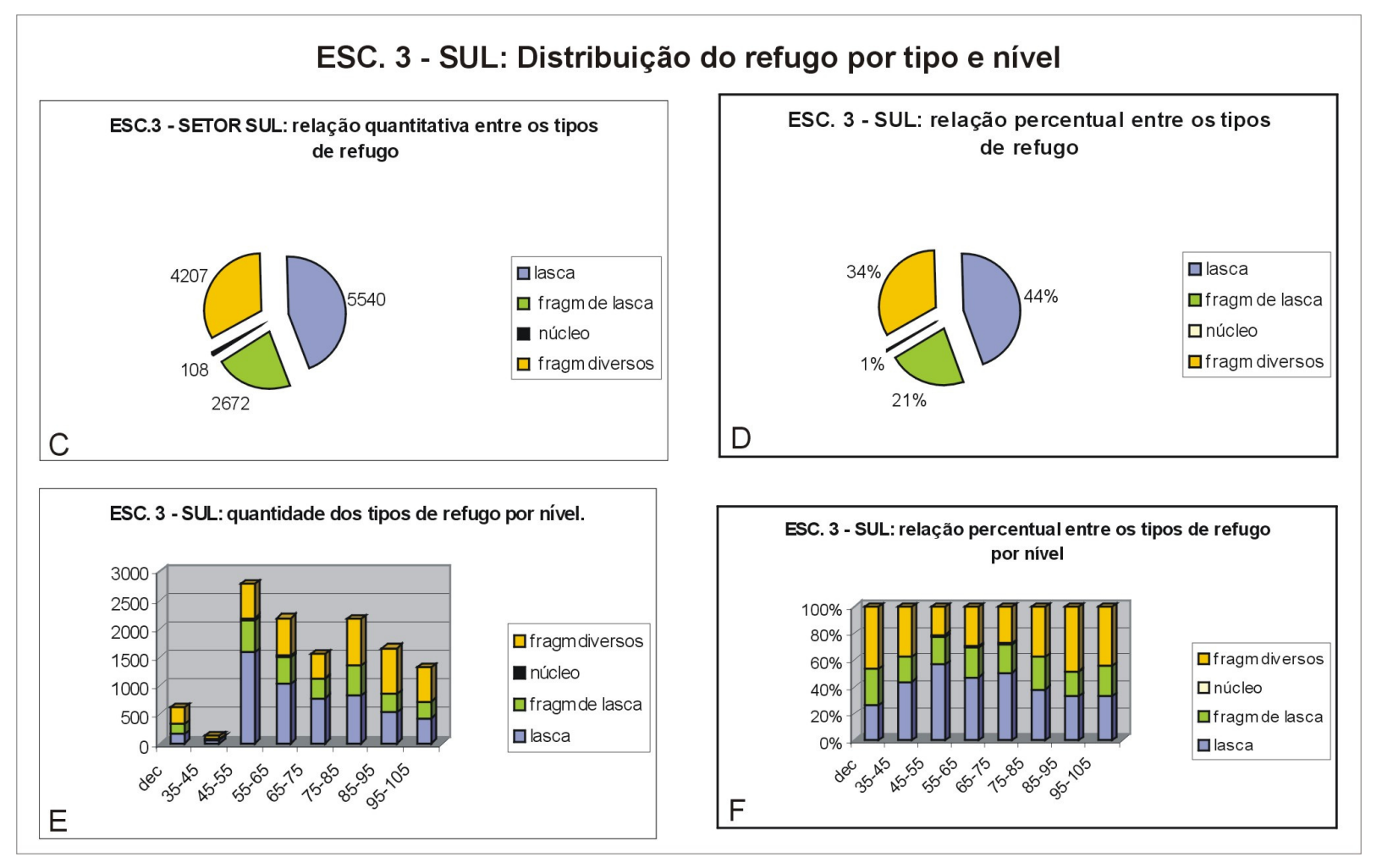

A categoria de fragmentos diversos representa todos fragmentos que não pertencem a nenhuma das três outras categorias, como blocos lascados (ou, cassons) e fragmentos térmicos. Estão bem representados no chert (a metade da amostra na Esc. 3 - Sul; ver figura $A$ duas páginas à frente), talvez por ser uma matéria-prima local encontrada em abundância; entretanto, não oferece muita informação acerca da tecnologia de lascamento. Os núcleos encontrados na escavação são relativamente poucos e se referem a dois principais tipos: núcleos unipolares em forma de lascas de chert ou quartzito com negativos de retiradas e sem gumes retocados (1) e núcleos bipolares de quartzo (2). Os fragmentos de lasca são fragmentos proximais, mesiais e/ou distais de lascas; representa, em número absolutos, quase a metade das lascas inteiras.

As lascas inteiras foram, em seguida, agrupadas por categorias de tamanho (por matéria-prima): micro-lascas, lascas pequenas, médias ou grandes.

As micro-lascas estão mais presentes no quartzito e quartzo, as duas principais matérias-primas utilizadas na produção de pontas bifaciais. As lascas pequenas predominam no chert, cujas principais ferramentas são raspadores unifaciais (ver tabelas pág. 106). 
ESC. 3 -SUL: distribuição das lascas inteiras por grupo de tamanho

ESC. 3 -SUL: relação quantitativa entre os tipos de lascas

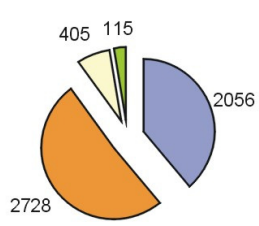

A

ESC. 3 - SUL: distribuição vertical das lascas inteiras por grupos de tamanho

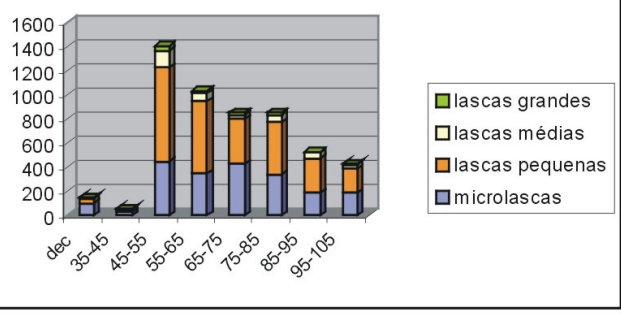

ESC. 3 - SUL: relação percentual entre os tipos de lascas

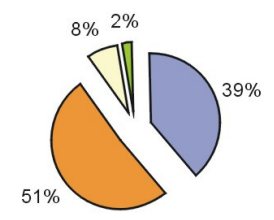

amicrolascas

口lascas pequenas

口lascas médias

口lascas grandes

B

ESC. 3 -SUL: relação percentual entre os tipos de lascas por nível

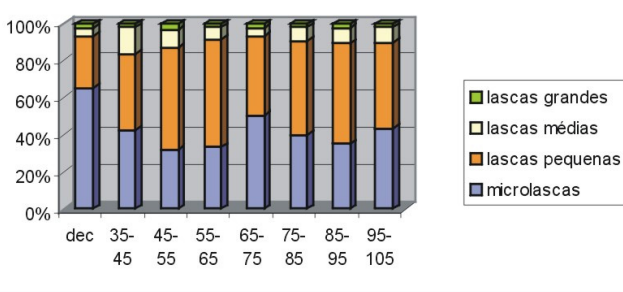




\section{GRUTA DO MARINHEIRO: Esc. 3 - Sul}

tipos de refugo por matéria-prima e nível
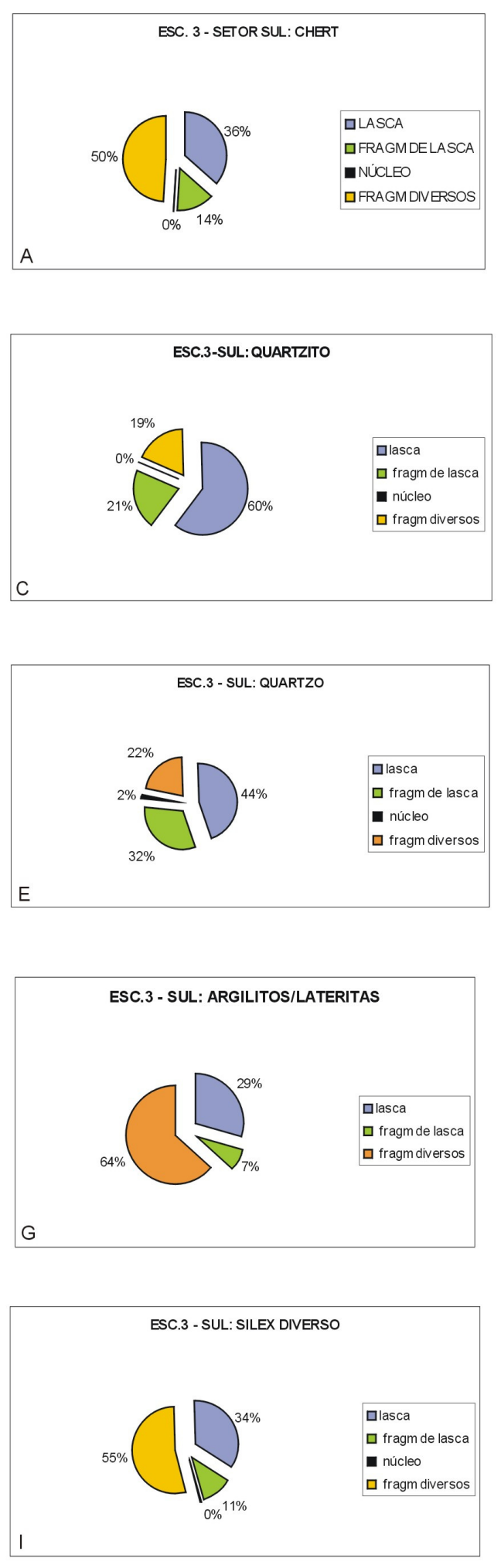
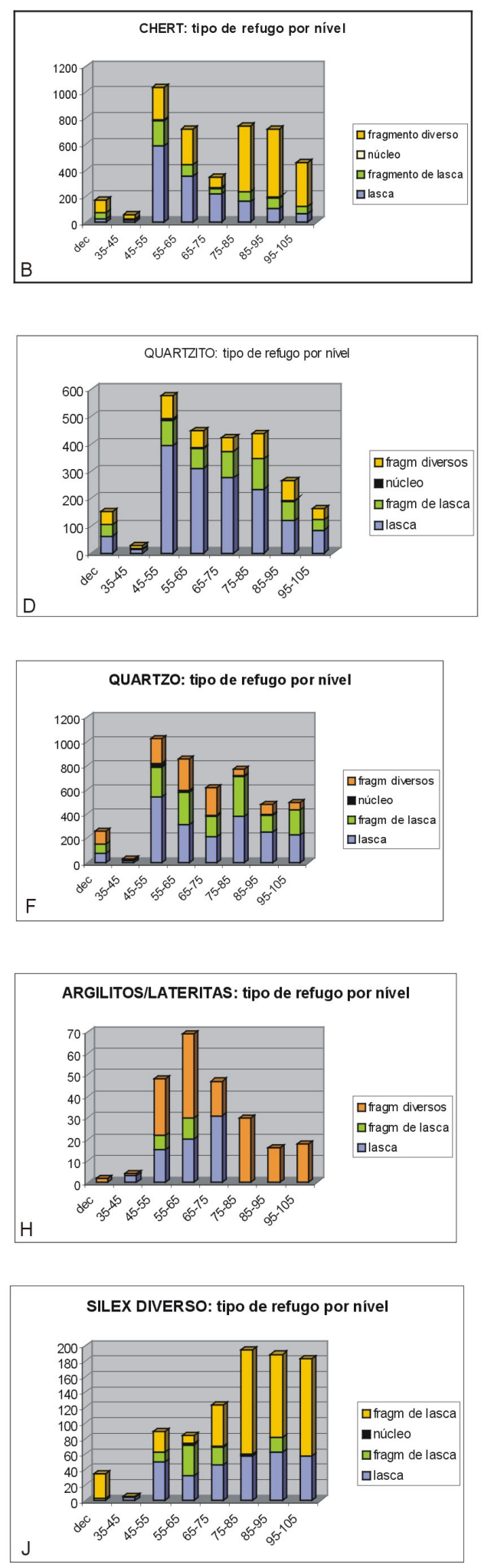


\section{GRUTA DO MARINHEIRO: Esc. 3 - Sul \\ lascas inteiras por matéria-prima}
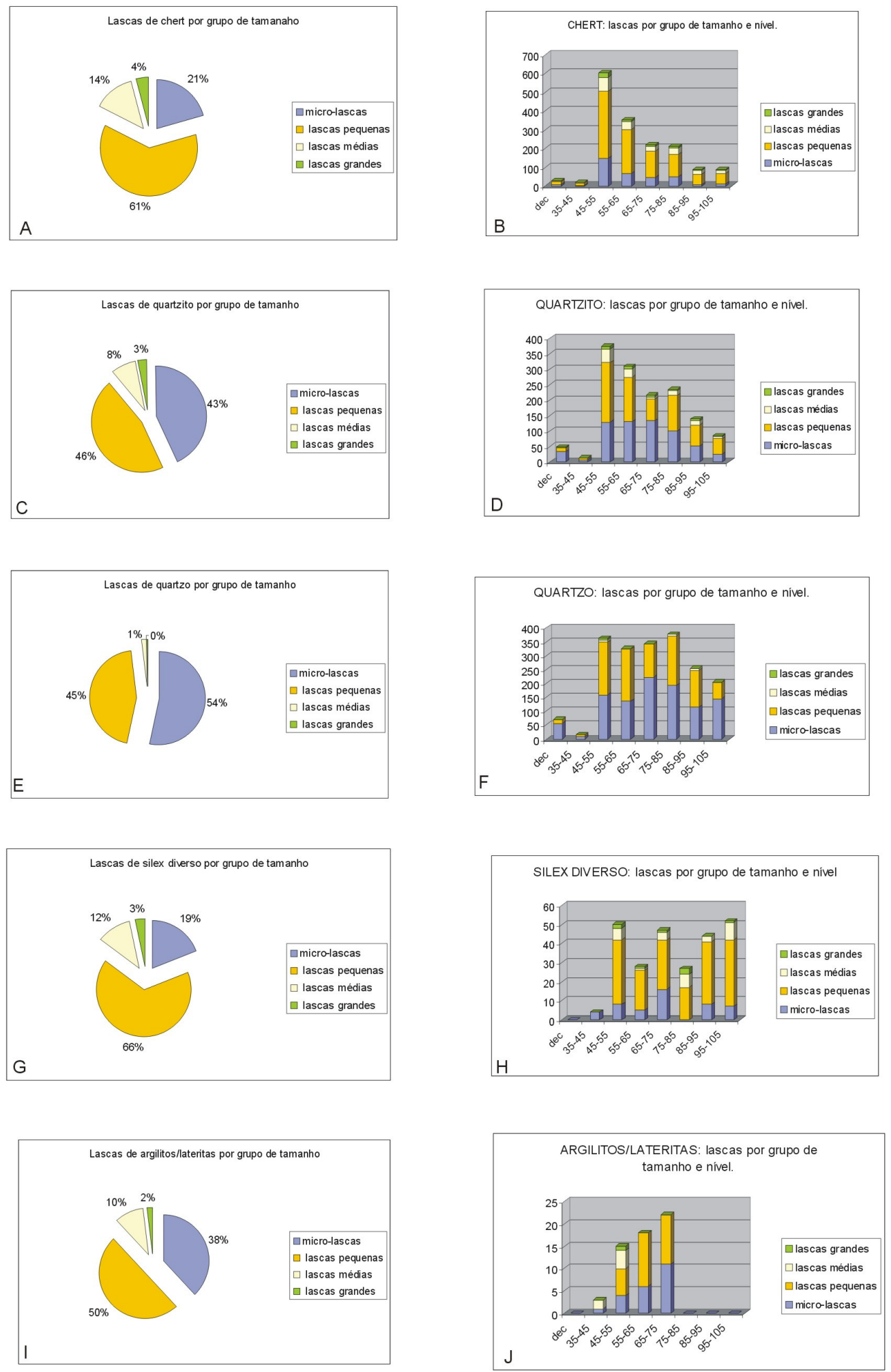


\subsection{2 - Análise cronológica e espacial}

A análise cronológica, limitada nesse sítio ao setor Esc. 3 -Sul, abrangeu um pacote contínuo com, em média, $70 \mathrm{~cm}$ de espessura a partir da superfície (dividido em 7 níveis arbitrários de $10 \mathrm{~cm}$ cada). Os níveis arbitrários utilizados são divisões horizontais que não seguem o desnível do terreno: para o setor Esc. 3 - Sul, representa cerca de $30 \mathrm{~cm}$ entre as extremidades norte e sul dessa quadra.

Tratava-se de um sedimento bastante uniforme em textura e cor: marrom escuro, argiloso, com pequenas manchas alaranjadas e carvões esparsos, recortado nos níveis superiores por raízes enquanto os níveis inferiores apresentavam, devido à ausência de raízes, uma compactação e dureza maior. Credita-se a alta homogeneidade do sedimento à sua exposição à água da chuva, que tende a acelerar o processo de desagregação das estruturas.

Duas datações radiocarbônicas foram obtidas para o pacote desse setor a partir de amostras de carvões esparsos (projetadas no perfil abaixo): a amostra mais rasa foi coletada a $20 \mathrm{~cm}$ da superfície $(\mathrm{NP}=2350)$; a mais profunda $(\mathrm{NP}=3737)$ estava enterrada a quase $70 \mathrm{~cm}$, poucos centímetros acima do sedimento estéril.

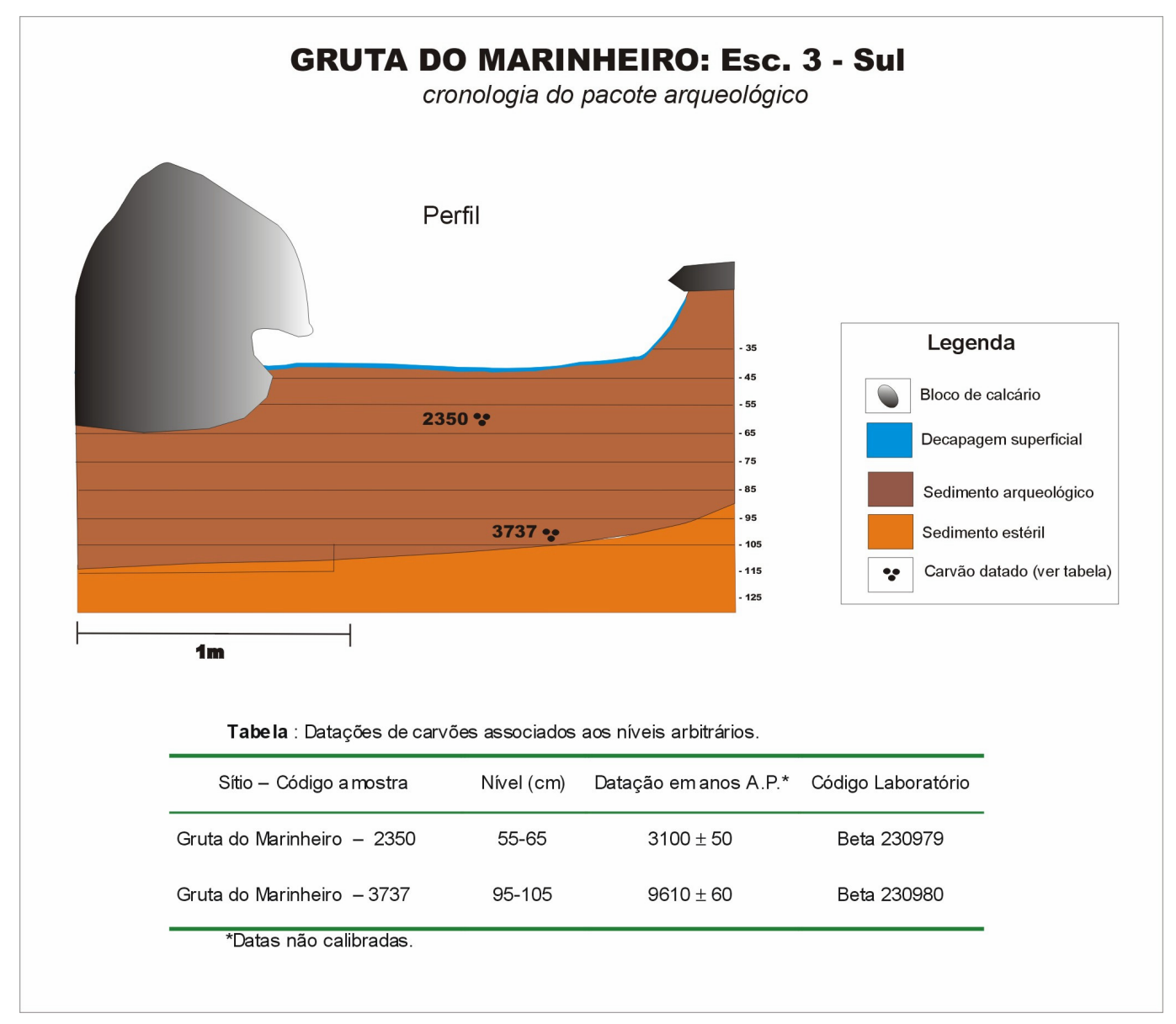


Os $40 \mathrm{~cm}$ que separam os níveis datados representam um intervalo temporal de cerca de 6510 anos, de $9610+/-60$ a 3100+/-50 anos AP. A maior densidade de refugo na Esc. 3 - Sul foi identificada no nível $45-55 \mathrm{~cm}$ (ver pág.105), situado pouco abaixo da superfície e um nível acima daquele com a datação mais recente (obtida no nível $55-65 \mathrm{~cm}$ ). A densidade do refugo decresce depois do nível $45-55 \mathrm{~cm}$, atingindo outra alta no nível $75-85 \mathrm{~cm}$, para em seguida cair de novo.

Observando a variação das matérias-primas, dos instrumentos, dos tipos de refugo e das lascas inteiras entre os diferentes níveis, constata-se, apesar das diferenças quantitativas, uma distribuição bastante homogênea dessas características em todo pacote arqueológico. Em outras palavras, a porcentagem que cada elemento, como tipo de matéria-prima, tipo de refugo, etc., representa por nível arbitrário é relativamente estável. A maior variação observada nas figuras $A, B, C$ e $D$ abaixo se refere aos instrumentos formais, que, em números absolutos, representam uma amostra bem menor e são dominados por pontas de projétil.

ESC. 3 - SUL: relação percentual entre as matérias-primas, os tipos de instrumentos e refugo e as lascas inteiras por nível.
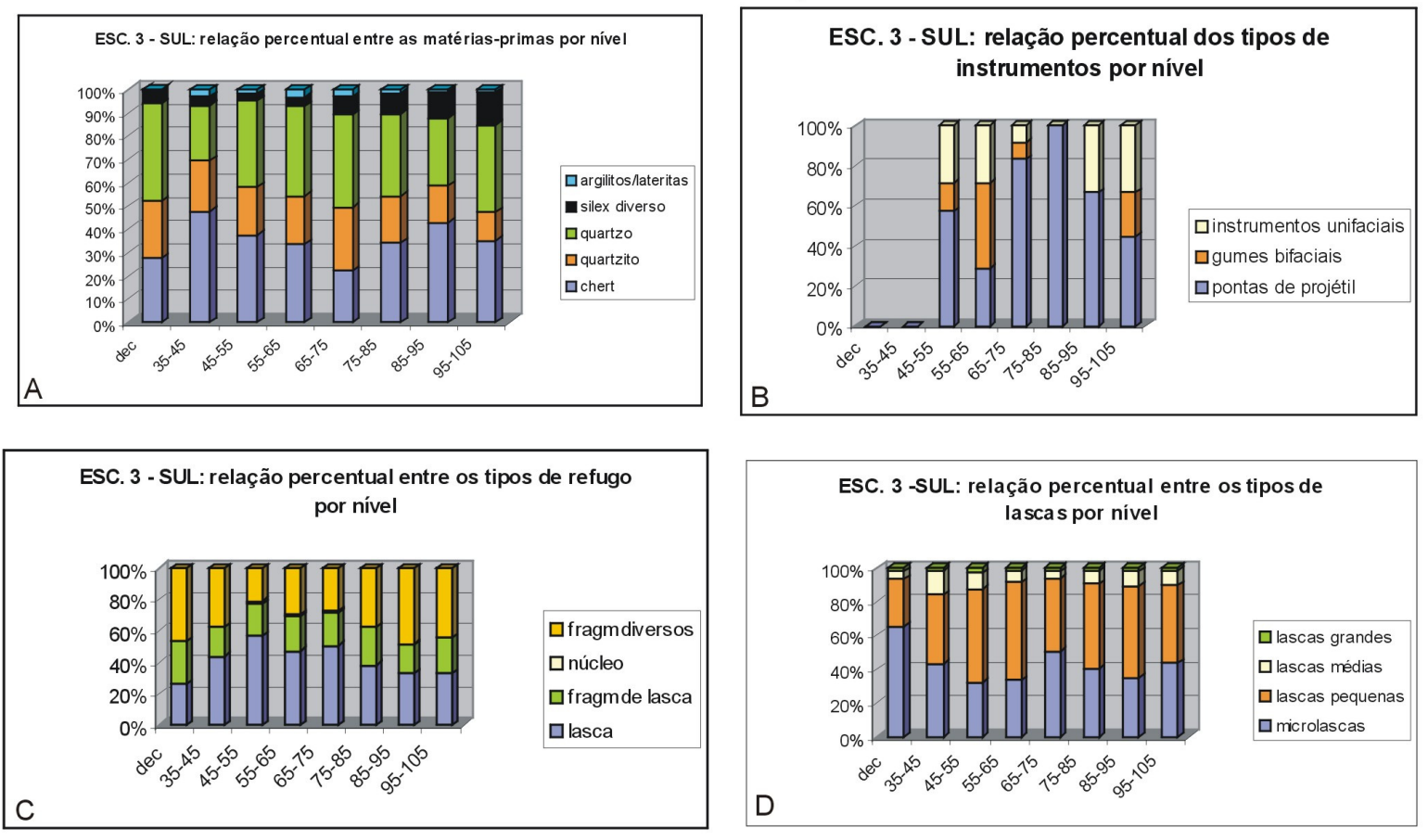

A determinação da função (ou várias funções) dos sítios acontece a partir da identificação dos tipos de vestígios, das estruturas arqueológicas e da função das ferramentas (ANDREFSKY, 2001:189). As estruturas podem ser, por exemplo, sepultamentos (como correu na Loca do Suim). Quando nenhuma estrutura pode ser definida, o reconhecimento do tipo de 
sítio recai sobre a função dos instrumentos e os tipos de vestígios. Isso foi o que aconteceu na Gruta do Marinheiro (nos estratos pré-cerâmicos), onde nenhuma estrutura bem definida foi encontrada. Por outro lado uma alta densidade de artefatos retocados foi recuperada, distribuída em três principais tipos: raspadores, facas e pontas de projétil. Em termos quantitativos essas últimas predominam.

Induz-se que as atividades realizadas no local foram: produção de pontas de projétil (e, talvez, descarte depois da utilização), como testemunha uma grande quantidade de refugo, marcado pelo aumento relativo do número de micro-lascas nas duas principais matérias-primas utilizadas (quartzito e quartzo) e a presença de pré-formas; a produção, uso e/ou descarte de raspadores e facas ${ }^{31}$, além do colocação de fogueiras, atualmente totalmente desestruturadas pela ação da chuva, e consumo de caça ${ }^{32}$.

Em termos espaciais (relação horizontal) pode-se distinguir três áreas utilizadas pelos caçadores-coletores na Gruta do Marinheiro:

- Área totalmente abrigada próxima às gravuras rupestres (Esc. 1): pelo aspecto geral e quantidade de peças da amostra obtida nesse setor, acredita-se que o local também foi ocupado pelos caçadores-coletores. Apresenta semelhanças nas matérias-primas empregadas, no entanto, não observa-se uma grande quantidade de instrumentos formais como na Esc. 3 - Norte e Sul: somente uma ponta de projétil fragmentada foi localizada.

- Área no limite abrigado (Esc. 3 - Norte e Sul): a grande quantidade de pontas de projétil e refugo de lascamento ligados à sua fabricação, como pré-formas, assim como estilhaços e micro-lascas de retoque, aponta para a fabricação de pontas no próprio local, ou seja, tratase de uma oficina lítica.

- Área externa, em frente à Entrada 02: área arada com vestígios líticos aflorando (contexto remexido).

A ausência de vestígios de caçadores-coletores na parte interna das cavernas como ocorreu na Gruta do Marinheiro (na Esc. 2), também já foi observado em sítios pesquisados anteriormente como na Gruta Mané do Juquinha (HENRIQUES, 2006).

\section{3 - Loca do Suim}

No sítio foram realizados quatro intervenções: uma escavação ampla (Área 1 com 626 peças) e três unidades (U2, U3, e U4), em diferentes áreas da entrada da caverna. As poucas peças coletadas nessas três unidades ainda não foram analisadas.

\footnotetext{
${ }^{31}$ A principal diferença entre as pontas e os outros instrumentos é que esse primeiro foi utilizado exclusivamente fora do seu local de produção, para obtenção de caça.
} 


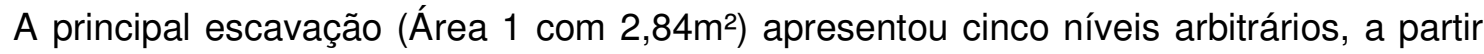
do nível $0-10 \mathrm{~cm}$ até o nível $40-50 \mathrm{~cm}$. A maior densidade de material encontrou-se no nível 20 30 , que representa a área de contato entre a camada cinza antrópica e os enterramentos humanos (ver perfil abaixo). A partir do nível $30-40 \mathrm{~cm}$ todos os vestígios estão associados aos sepultamentos. O nível 50-60 não forneceu vestígios líticos.

O Laboratório IB/USP mandou datar amostras de osso coletadas nos Sep. I e II.

Tabela : Datações de C14 para os Sep. I e II .

\begin{tabular}{cccc}
\hline Sítio - Código amostra & Município & Datação em anos A.P. & Código Laboratório \\
\hline Loca do Suim - LSPAINSSEPII & Pains & $7460 \pm 50$ & Beta 210401 \\
Loca do Suim - LSPAINSSEPI & Pains & $7350 \pm 50$ & Beta 210400 \\
\hline
\end{tabular}

Poucas peças com retoques foram encontradas: trata-se de três instrumentos com duas facas unifaciais e um raspador unifacial fragmentado. No que concerne o refugo de lascamento, 303 lascas inteiras foram coletadas (48\% da amostra). Os $51,5 \%$ restantes são fragmentos de lascas (199 peças) e fragmentos diversos (121 peças, principalmente térmicos).

Em relação às lascas, as pequenas são maioria em todos níveis, seguidas pelas médias. As lascas grandes e as micro-lascas são bem menos freqüentes. Em relação às matériasprimas, a presença de calcário e a ausência da categoria argilitos/lateritas se destacam. Ver figura $B$ em baixo: nos três níveis mais densos há uma continuidade percentual das matériasprimas.

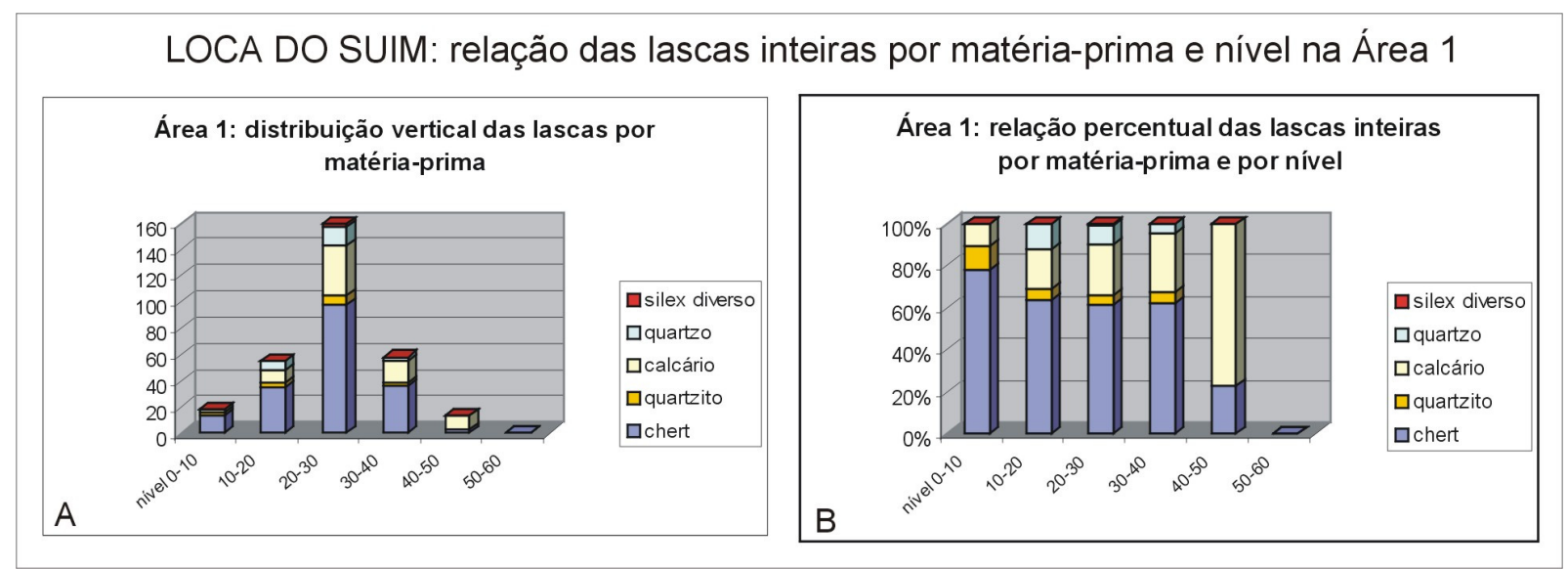

\footnotetext{
${ }^{32}$ Foram identificados ossos de veado, paca e macaco de amostra proveniente da Esc. 3 - Sul por Caroline Borges (comunicação pessoal), mestranda do MAE/USP.
} 


\section{4 - Material lítico coletado em superfície}

A amostra proveniente dos sítios restantes foi toda coletada em superfície, sendo que somente o Abrigo Lagoa de Peixe forneceu refugo de lascamento. Nos outros sítios (Perdição I, Abrigo Lagoa do Retiro, Abrigo da Estiva etc.) foram coletadas apenas peças retocadas em superfície, na maioria dos casos em locais erodidos. A amostra de superfície, com 168 peças, não teve datação, mas supões-se que, justamente por se encontrar em superfície, pertence ao final da ocupação caçadora-coletora na Província, ou, pela morfologia e matéria-prima de algumas peças, até à ocupação dos horticultores-ceramistas.

O sítio Abrigo Lagoa do Peixe tem uma amostra de 152 peças proveniente de uma coleta de superfície, em locais erodidos. Esse conjunto apresentou 97 lascas, 5 núcleos, 5 suportes retocados e fragmentos de origem diversa. As matérias-primas são chert, quartzo (leitoso, translúcido e hialino), quartzito e silex diverso (HENRIQUES JR, G., COSTA, F. e KOOLE, E., 2001).

A maioria das lascas inteiras (62\%) são de debitagem que caracterizam a retirada de volume indesejado do suporte ou núcleo. São lascas de tamanho médio $(55 \%)$ e grande $(7 \%)$ e possuem poucos negativos na face externa; o perfil dessas lascas não denuncia a formatação de uma peça e o talão é pouco ou nada trabalhado. A sua forma final não é importante: nesta etapa os lascadores visavam a preparação dos núcleos para retirada de lascas ou dos suporte para o início do talhe e em seguida, retoque. Entre as lascas de debitagem foram identificadas lascas de regularização de flanco de núcleos cuja extração visava a retirada de quinas e arestas indesejáveis, tão comuns nos blocos quadrangulares de chert e quartzito.

Por outro lado, foram encontradas lascas de talhe interessantes, estas se manifestando principalmente entre os outros tipos de matéria-prima: silex diverso, cristal de quartzo hialino e variedades de quartzito. Algumas lascas de silex diverso são extremamente delgadas cuja face externa, repleta de negativos, denota o trabalho meticuloso para a fabricação de pequenas peças. Algumas possuem talão puntiforme ou em forma de asa, tentativas por parte do lascador de determinar antes do golpe decisivo a forma das lascas a serem extraídas. O mesmo se vê nas lascas de retoque de gumes, etapa subsequente à de talhe, o trabalho para obtenção de talões lineares que atribuem uma espessura delgada à lasca.

Identificou-se uma lasca, remontada em laboratório, que foi extraída para a formatação de uma peça bifacial como se pode verificar no ângulo de $148^{\circ}$ formado na junção de seu talão com a face interna. Encontrou-se também 3 lascas com refugo da reavivagem de um gume retocado; tal processo se dava quando o gume de uma ferramenta ficava gasto ou se danificava durante o uso, sendo necessário a sua reativação através de nova sélrie de retoques que 
geravam como refugo lascas cuja proximal externa encerra, em geral, parte do antigo gume gasto com seus respectivos negativos de retoque e estilhaçamentos de uso.

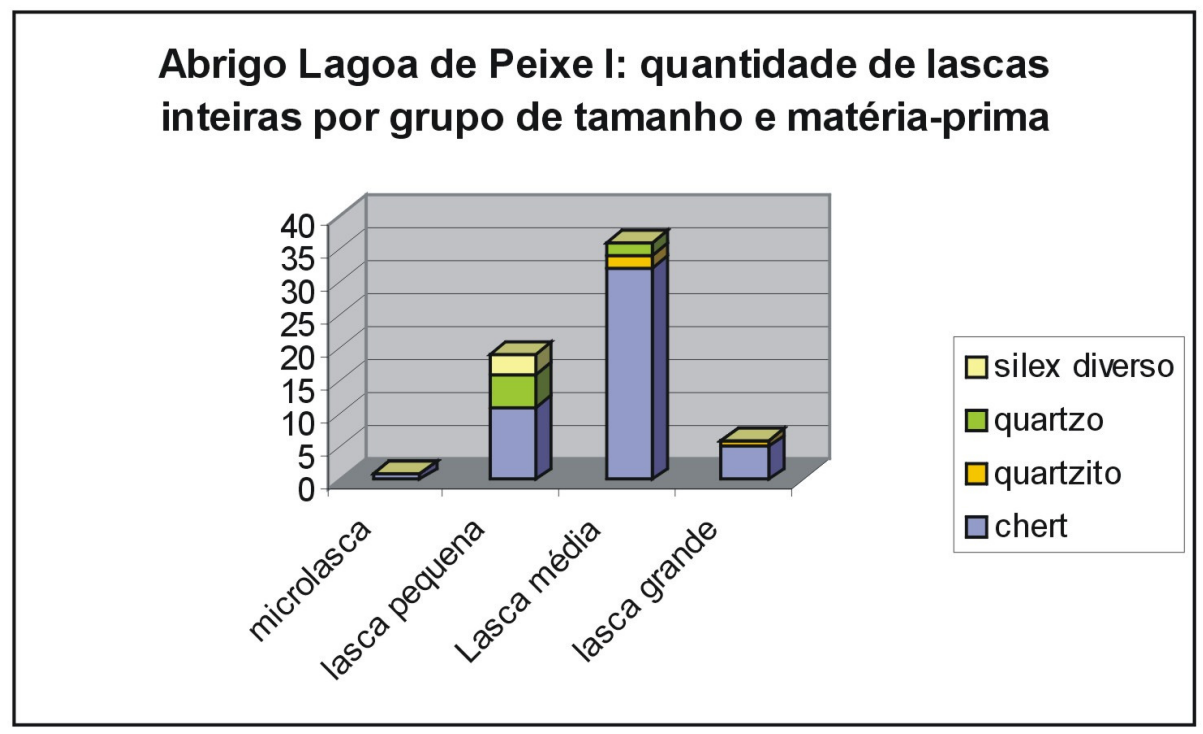

Se comparado com a amostra mais superficial obtida na Gruta do Marinheiro, com mais de $60 \%$ de micro-lascas e supondo que se trataria de uma mesma indústria, a coleta sistemática de superfície, com uma predominância de lascas médias, distorceu a amostra em favor de lascas maiores que são mais visíveis e, portanto, mais facilmente coletadas do que as micro-lascas.

O material possui 6 peças caracterizadas como suportes retocados; um deles consiste em uma raspadeira sobre lasca cortical encontrada em estrada de acesso ao sítio. As outras 5 foram encontradas no sítio. O conjunto é composto por peças de pequenas dimensões entre 3 e $7 \mathrm{~cm}$, senda a raspadeira a maior peça.

Há particularmente 2 fragmentos que pertenciam a instrumentos muito bem acabados com formas lembrando os plano-convexos do norte mineiro, um deles um pequeno e delgado raspador que possui um brilho sutil em uma das laterais (em decorrência do uso ou da pingueira?) O outro aparenta ter sido lascado mesmo após ter se fraturado; sua matéria-prima o quartzito, encontrado fora do carste na Serra da Pimenta, talvez explique essa reutilização intensiva.

Identificou-se 5 peças como núcleos; têm entre 4,2 e 8,4 cm de dimensão máxima, um é de quartzito enquanto o restante é de silex preto. Três deles ainda possuem vestígios de córtex. Um apresenta uma forma globular, possuindo 4 planos de percussão explorados e 6 negativos em sua superfície; os outros têm 1 ou 2 planos de percussão, possuem 3 ou 5 negativos cada um; um núcleo possui apenas 2 negativos, o que coloca a sua identificação como núcleo em dúvida. As dimensões destes negativos oscilam desde $1,5 \mathrm{~cm}$ (no núcleo menor) até $5 \mathrm{~cm}$ de dimensão máxima; não é muito diferente do padrão de dimensões das lascas encontradas no 
sítio, o que leva a crer que os lascadores estavam lidando no sítio tanto com peças já desbastadas em outros lugares quanto com blocos naturais não muito diferentes em volume dos núcleos abandonados no sítio.

Entre os fragmentos de origem diversa encontrou-se 27 fragmentos de dimensões milimétricas provenientes de lascas que se fraturaram; 10 fragmentos milimétricos de feição quadrangular que geralmente se estilhaçam dos blocos no momento da fratura das lascas. Encontrou-se apenas 1 fragmento que se originou de uma fratura térmica; uma amostra reduzida, este não é porém o único vestígio relacionado à combustão dentro do abrigo, algumas lascas de silex e quartzito apresentam uma rubeifação muito próxima da deixada pelo fogo; estas lascas podem ter ficado em contato com uma fogueira feita no interior do abrigo.

A vinculação desse material com grupos de caçadores-coletores está fora de dúvida: o material lítico aparece sob abrigos calcários restringido a zonas de pingueira; raramente com fragmentos cerâmicos que, por sua vez, são abundantes em superfície; o material lítico que aparece nos sítios cerâmicos têm características morfológicas e tecnológicas totalmente díspares do material em questão; por fim, a frequência de atributos presentes denota um lascamento fino, principalmente visível nos grupos de lascas. Essas características são: talões em asa, puntiformes, lineares; perfils delgados, por vezes curvos; faces externas repleta de negativos com justaposições e sobreposições variadas, mas sendo reconhecíveis em muitas peças a seqüência de talhe seguida pelo retoque. 


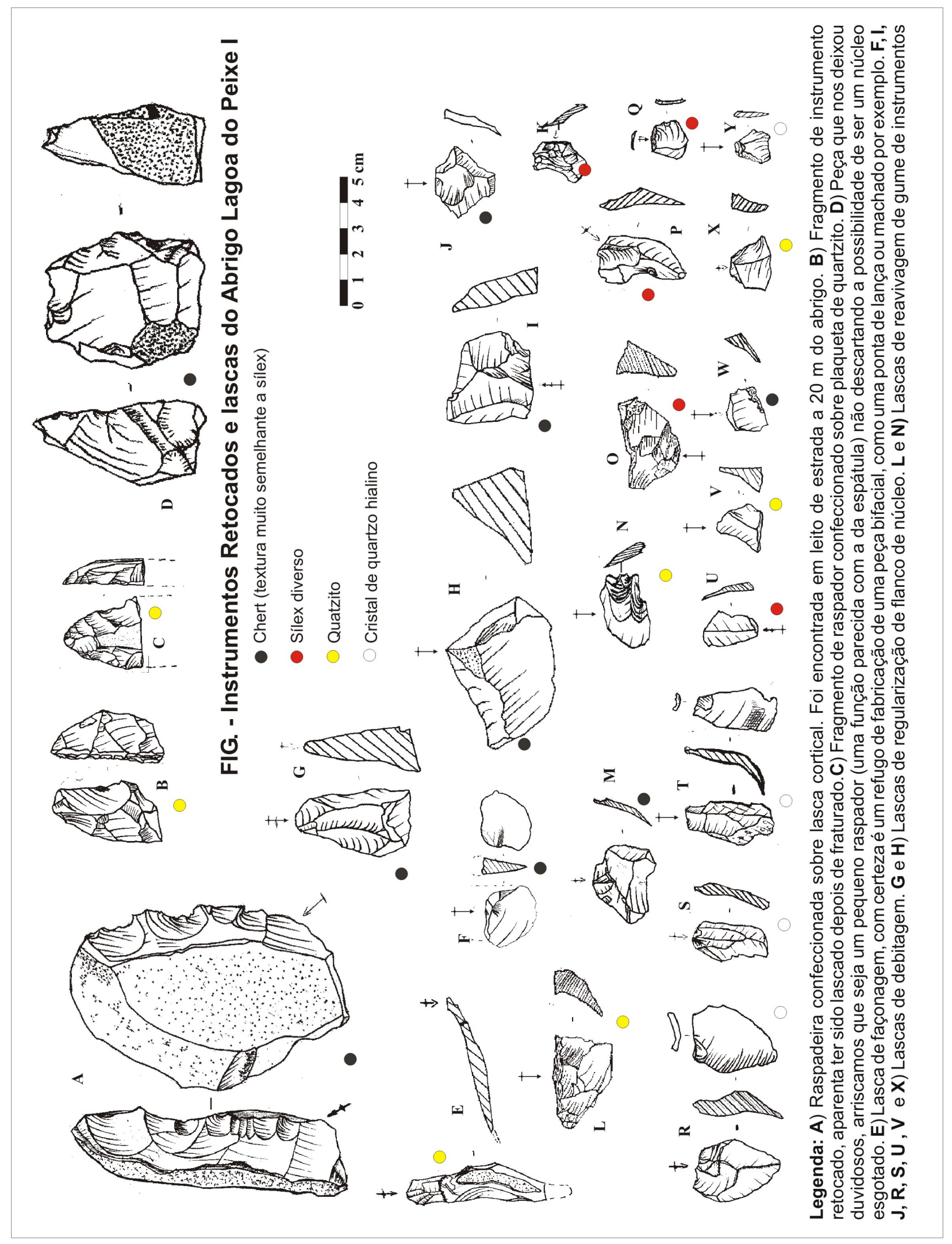


Em outros 10 sítios e 4 ocorrências foram coletados 15 instrumentos em superfície, divididos da seguinte maneira: duas peças bifaciais e 13 unifaciais. As peças unifaciais se distribuem em raspadores de diversos tipos: raspadores laterais, circulares, trapezoidais e alongados.

Dois raspadores laterais robustos, peças 1066 e 1082 abaixo (nos desenhos, com gumes na borda esquerda), foram encontrados na superfície de dois abrigos ${ }^{33}$ fora das áreas de erosão, o que pode significar que são de data mais tardia do que o material das pingueiras. Ambos foram confeccionados sobre uma matéria-prima pesada, ainda desconhecida, de provável origem exógena. Foi realizado um teste com ácido pelo geólogo Alexandre Pizarro para ver se tratava de calcário: o experimento deu negativo para ambas ferramentas. Essas duas peças se diferenciam significativamente (principalmente no tipo de matéria-prima utilizada e nas dimensões) dos outros vestígios unifaciais que comportam a amostra de superfície deste trabalho. A maioria das outras peças foram coletadas em pingueiras de abrigos e grutas e são mais parecidas entre $\mathrm{si}^{34}$.

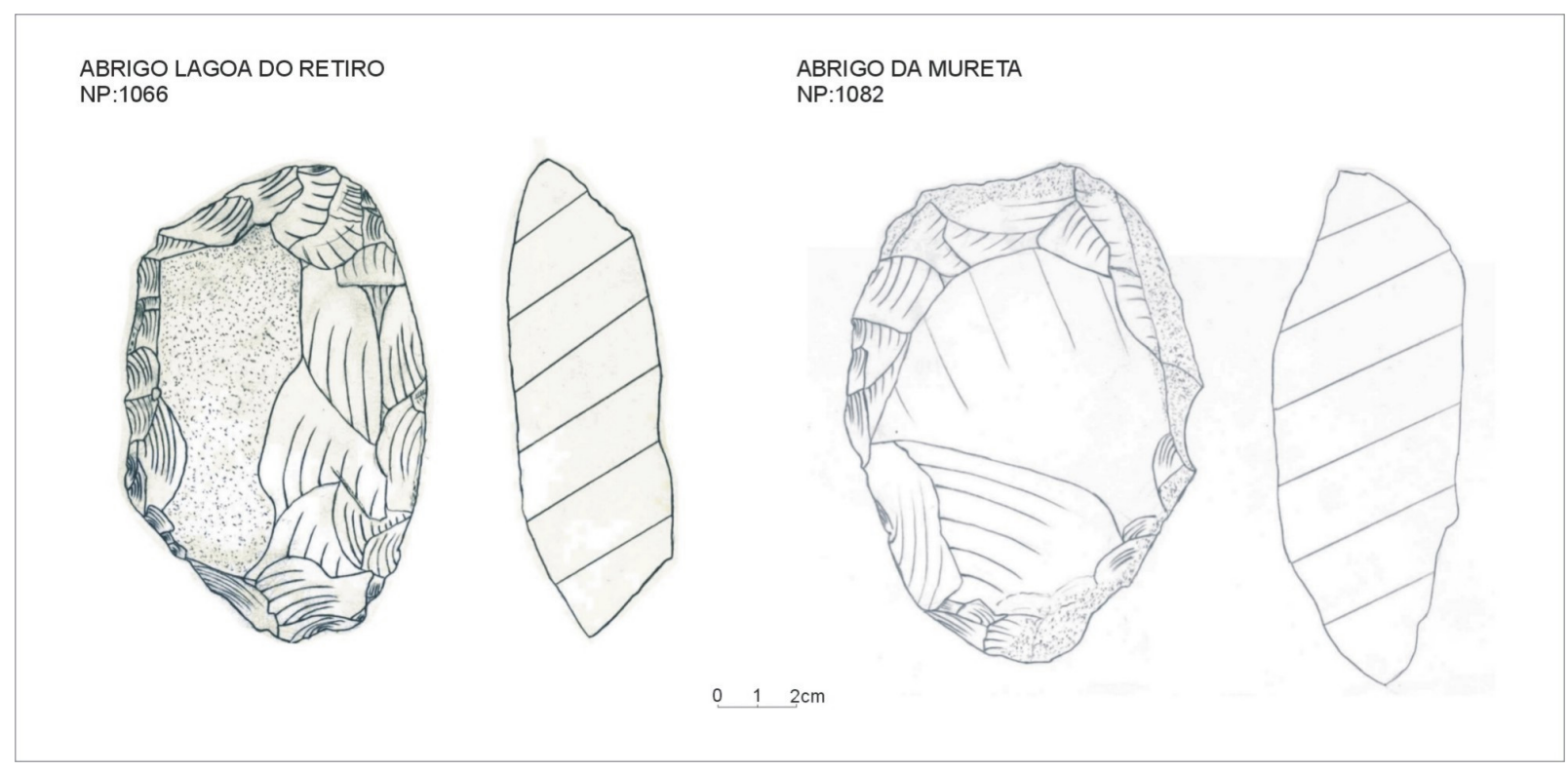

\footnotetext{
${ }^{33}$ O sítio Abrigo da Mureta (origem da peça 1082) está a uma distância de cerca $20 \mathrm{~km}$ em relação ao Abrigo Lagoa do Retiro (origem da peça 1066).

${ }^{34}$ Alguns exemplos: raspador circular de silex preto em quartzito encontrado em superfície do sítio Abrigo do Ângelo; raspador tipo "plano-convexo" de quartzito, encontrado em ocorrência isolada na região do Brejão, na bacia do Ribeirão dos Patos; raspador tipo "plano-convexo" no sítio Perdição; raspador lateral sobre plaqueta de silex preto (1080) localizado em "pingueira" do sítio Abrigo da Mureta.
} 


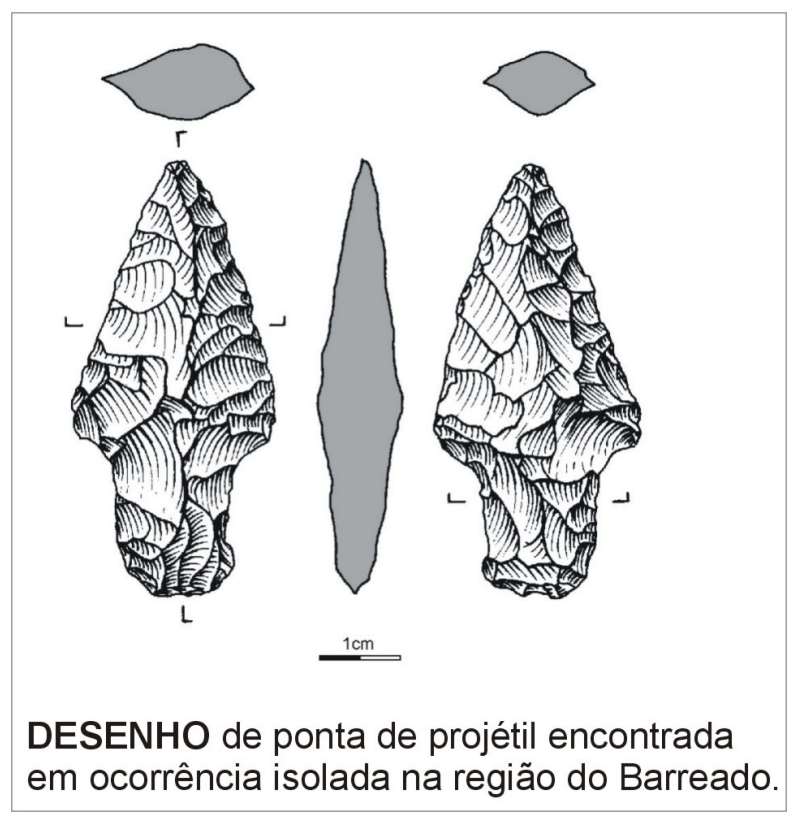

\section{5 - Cronologia Geral}

A amostra lítica analisada no presente trabalho pertence, como apresentado nos itens anteriores, a três contextos de deposição diferenciados: proveniente de superfície e das escavações na Esc. 3 - Sul (Gruta do Marinheiro) e na Área 1 (Loca do Suim).

Para os locais que forneceram apenas material lítico lascado de superfície, envolvendo 11 sítios e 4 ocorrências, não se obteve datações absolutas e, por ser uma amostra superficial, porém proveniente de um contexto subsuperficial (áreas erodidas), foi provisoriamente agrupada no final do período arcaico ${ }^{35}$ (ver faixa temporal na figura em baixo).

Uma amostra de carvão originária do setor Esc.3 - Sul, escavado na linha de gotejamento d'água na Gruta do Marinheiro $\left(5 \mathrm{~m}^{2}\right)$ forneceu a data mais recente para o arcaico na região, $3100+/-50$ anos AP (não calibrada), obtida a cerca de $20 \mathrm{~cm}$ de profundidade. Por ser uma área naturalmente erodida, o pacote contendo a alta densidade de material lítico, associado a uma indústria caçadora-coletora, se iniciava já na superfície do piso, dois níveis de $10 \mathrm{~cm}$ acima dessa coleta. Por isso, acredita-se que a ocupação pode ser ainda mais recente que essa data. Entre ela e a data mais antiga do arcaico, proveniente do mesmo pacote a $70 \mathrm{~cm}$ de profundidade, alguns centímetros acima do pacote estéril, existe uma grande distância temporal de cerca de 6500 anos. Uma questão ainda duvidosa é se a ocupação foi contínua durante todo esse intervalo, talvez com períodos de maior intensidade, ou se em determinado

\footnotetext{
${ }^{35}$ Com exceção de dois raspadores laterais robustos que podem ser posteriores.
} 
momento houve uma interrupção com uma certa duração, como parece ter ocorrido com vários sítios de Lagoa Santa e do Brasil Central.

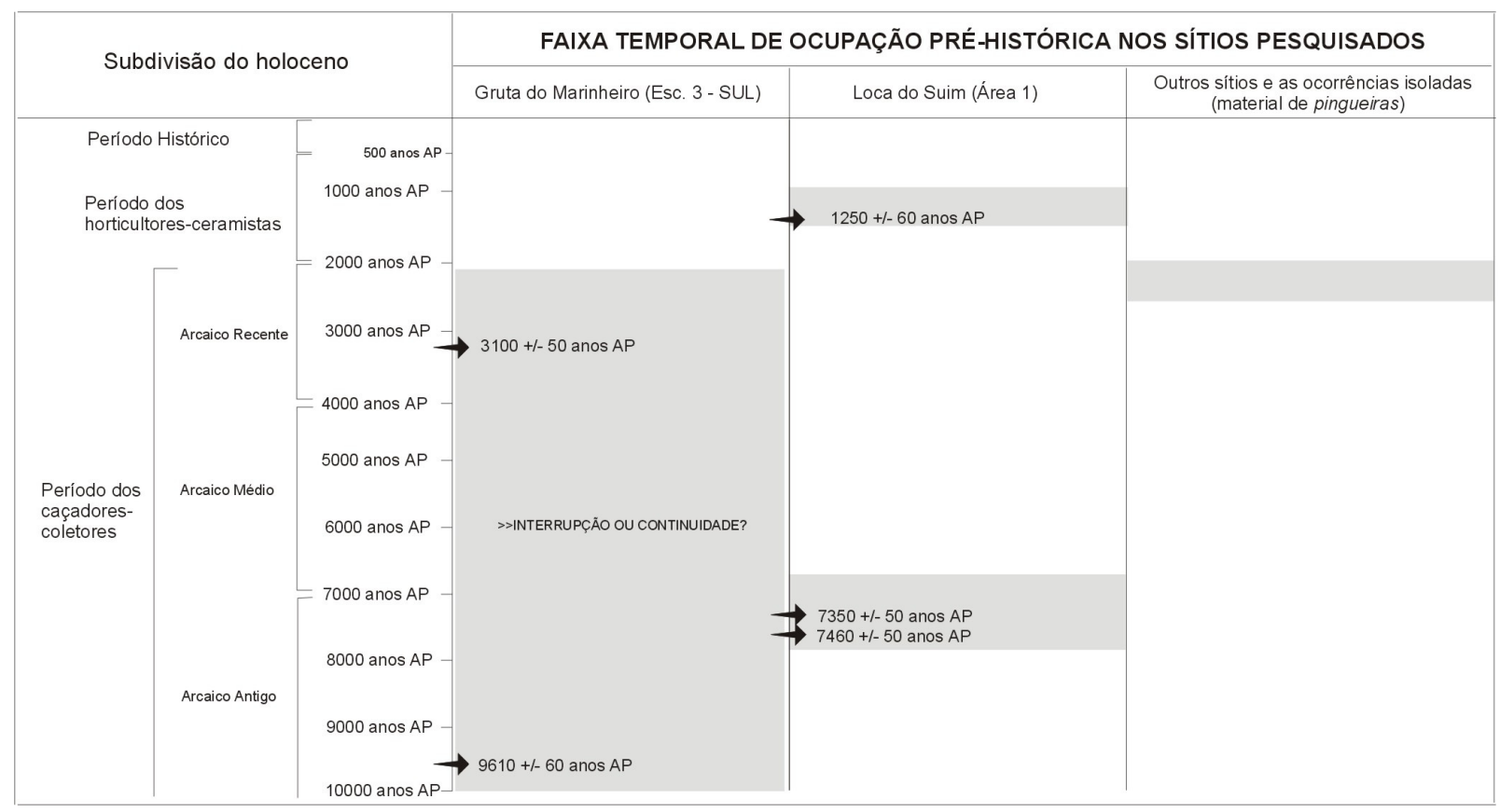

O que se sabe é que os vestígios líticos apresentaram um alto grau de homogeneidade qualitativa, tanto no que concerne as matérias-primas empregadas, quanto os tipos de instrumentos e refugo produzidos, ao longo de todos níveis arbitrários da Esc. 3 - Sul. O destaque vai para a predominância de uma ferramenta formal em particular, a ponta de projétil bifacial, presente a partir do segundo nível arbitrário, ou seja, a partir de $10 \mathrm{~cm}$ de profundidade.

O material lítico proveniente do setor Área 1, local totalmente abrigado próximo a uma parede lateral na Loca do Suim $\left(3 \mathrm{~m}^{2}\right)$, forneceu uma amostra associado a sepultamentos do final do arcaico antigo (a mais de 7 mil anos AP) e a sedimentos antrópicos em níveis localizados acima dessas estruturas de enterramento. $O$ fato de um carvão, coletado a $16 \mathrm{~cm}$ de profundidade na Área 1 e datado a pouco mais de 1200 anos AP, se encontrar apenas $10 \mathrm{~cm}$ acima do início do Sep. I (começou a aparecer a cerca de $25 \mathrm{~cm}$ de profundidade), é notável: uma distância temporal de mais de 6000 anos separada por apenas $10 \mathrm{~cm}$ de um pacote cinza. O material coletado aqui se diferencia daquele da Gruta do Marinheiro por ter praticamente nenhuma peça retocada, apesar de apresentar as quatro principais matérias-primas (chert, quartzito, quartzo e silex diverso) encontradas no Marinheiro.

A Loca do Suim, além de apresentar uma menor área abrigada, se diferencia desse sítio por ter na sua parte externa, logo em frente da entrada, um declive acentuado, o que limitaria o espaço disponível para uma ocupação mais extensa do local. Acredita-se que se trate de um 
tipo mais limitado de utilização do espaço (fora os próprios sepultamentos, o sítio tem poucos vestígios significativos para o período pré-ceramista), mas talvez associado aos mesmos grupos caçadores-coletores cujos vestígios foram encontrados na Gruta do Marinheiro, o que, entretanto, ainda não se pode afirmar categoricamente. $O$ enterramento humano nos abrigos e cavernas, apesar de apenas um sítio escavado ter apresentado sepultamentos, parece ter sido uma prática recorrente na região em questão ${ }^{36}$, como foi também na região de Lagoa Santa, entretanto, depende ainda de pesquisas futuras.

${ }^{36}$ Indícios de um sepultamento, com osso humano aflorando no piso sedimentar, foi encontrado em outro sítio (Abrigo Mata da Fruta). 


\section{CONSIDERAÇÕES FINAIS}

O presente estudo demonstrou que algumas características atribuídas à tradição Umbu apresentam semelhanças notáveis com um pacote de $70 \mathrm{~cm}$ de espessura proveniente da Esc. 3 - Sul da Gruta do Marinheiro, sítio localizado a cerca de $300 \mathrm{~km}$ ao nordeste de Rio Claro $(\mathrm{SP})^{37}$, a presença Umbu mais próxima conhecida. Essas características são:

- A preponderância de pontas de projétil sobre os demais instrumentos formais, distribuídas sobre praticamente todos os níveis arqueológicos (na Esc. 3 - Sul a partir de $10 \mathrm{~cm}$ de profundidade).

- A grande quantidade de resíduos ligados à produção desses artefatos, inclusive préformas, com destaque para as micro-lascas $(<1 \mathrm{~cm}$ de comprimento segundo eixo tecnológico).

- A presença também, em menor número, de variedades de "raspadores" unifaciais e gumes bifaciais.

- Uma cronologia semelhante: abrangendo o início do holoceno (arcaico antigo) e o arcaico recente ${ }^{38}$.

- Um pacote com uma relativa homogeneidade qualitativa de vestígios ao longo de todos níveis arbitrários, variando mais quantitativamente.

Outros locais também contribuíram com indícios em favor da idéia de uma "proximidade cultural" com a tradição Umbu. O sítio Abrigo da Lagoa do Retiro, e uma ocorrência isolada, localizados na borda sudeste e sudoeste da Província, respectivamente, também tinham, cada um, uma ponta de projétil em superfície. Vários sítios na Província apresentam "pingueiras" com vestígios líticos lascados, como ocorreu no sítio Abrigo Lagoa de Peixe I. Aqui uma coleta de superfície revelou instrumentos unifaciais fragmentados e refugo de lascamento. A coleta, com exceção de algumas peças, não permitiu vislumbrar uma produção bifacial intensa, o que foi atribuído à coleta (involuntária) das peças mais visíveis no piso, proporcionando uma amostra distorcida, com predominância de lascas médias.

A região em que a Província se encontra, o centro-oeste mineiro, foi ainda pouco pesquisada pela arqueologia. Entretanto, sabe-se da existência de sítios com pontas de projétil nas margens do Lago de Furnas (a céu aberto) graças ao colecionador Antônio Adauto Leite do município de Carmo do Rio Claro, localizado $80 \mathrm{~km}$ ao sudoeste da Província Cárstica do Alto

\footnotetext{
${ }^{37}$ Por outro lado, a utilização dos abrigos para enterramentos aproxima a Província, em termos arqueológicos, à região de Lagoa Santa.

${ }^{38}$ Não sabe-se ainda se houve uma interrupção da ocupação durante o arcaico médio, o que pode ser esclarecido com datações radiocarbônicas de carvões provenientes dos níveis intermediários da Esc. 3 Sul.
} 
São Francisco. A coleção particular, além de vestígios de horticultores-ceramistas, apresenta mais de 50 pontas de projétil com semelhanças marcantes àquelas encontradas na Gruta do Marinheiro (ver fotos A, B, C e D abaixo), que são: utilização de quartzito, inclusive plaquetas, e quartzo como matéria-prima; preponderância de pontas de tamanho médio, aletas obtusas e pedúnculos convexos e planos. Essa região pertence já à bacia do rio Grande, um dos principais formadores do rio Paraná. Em um sítio no mesmo município uma ponta de dimensões maiores $^{39}$ (ver desenho abaixo) e raspadores unifaciais também foram descobertos.

As evidências arqueológicas indicam, portanto, que as populações caçadoras-coletoras, produtoras de pontas de projétil de pedra, não limitavam seu campo de atuação apenas ao carste, exploravam também os ambientes vizinhos para o sudoeste, em direção a Rio Claro, no estado de São Paulo (ver mapa na página 122).

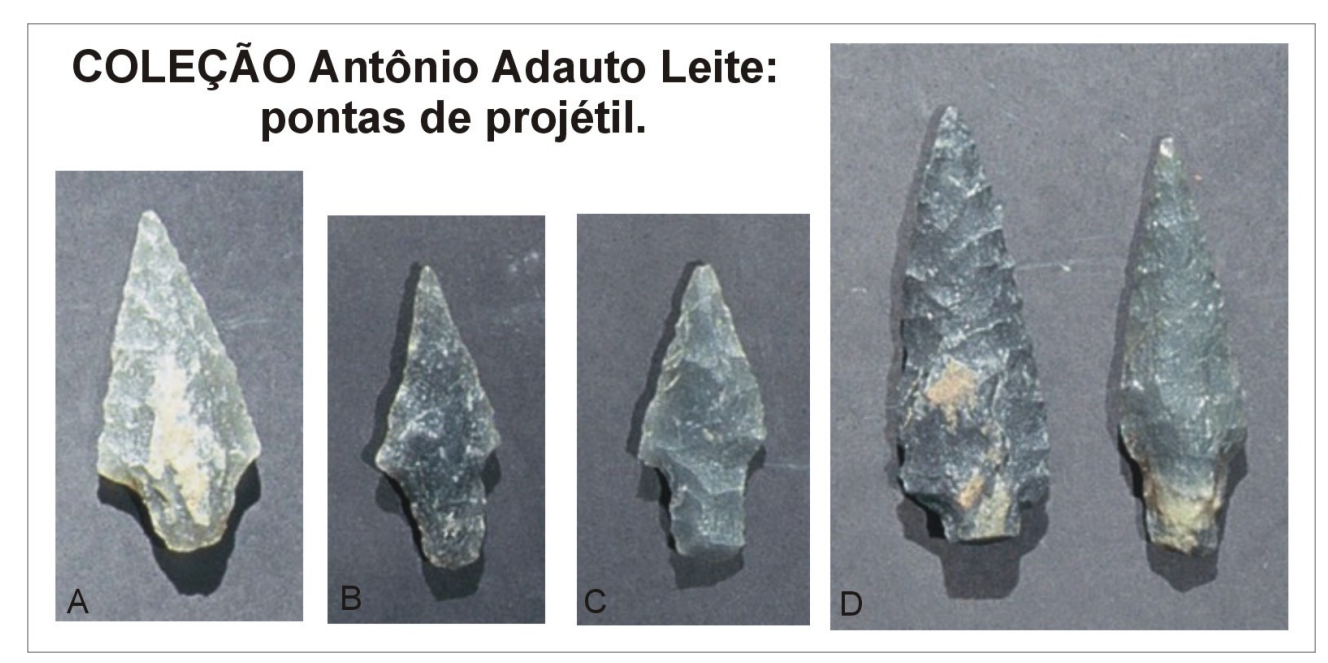

${ }^{39} \mathrm{O}$ que indica a existência de uma maior variabilidade morfológica de pontas de projétil do que pôde ser 


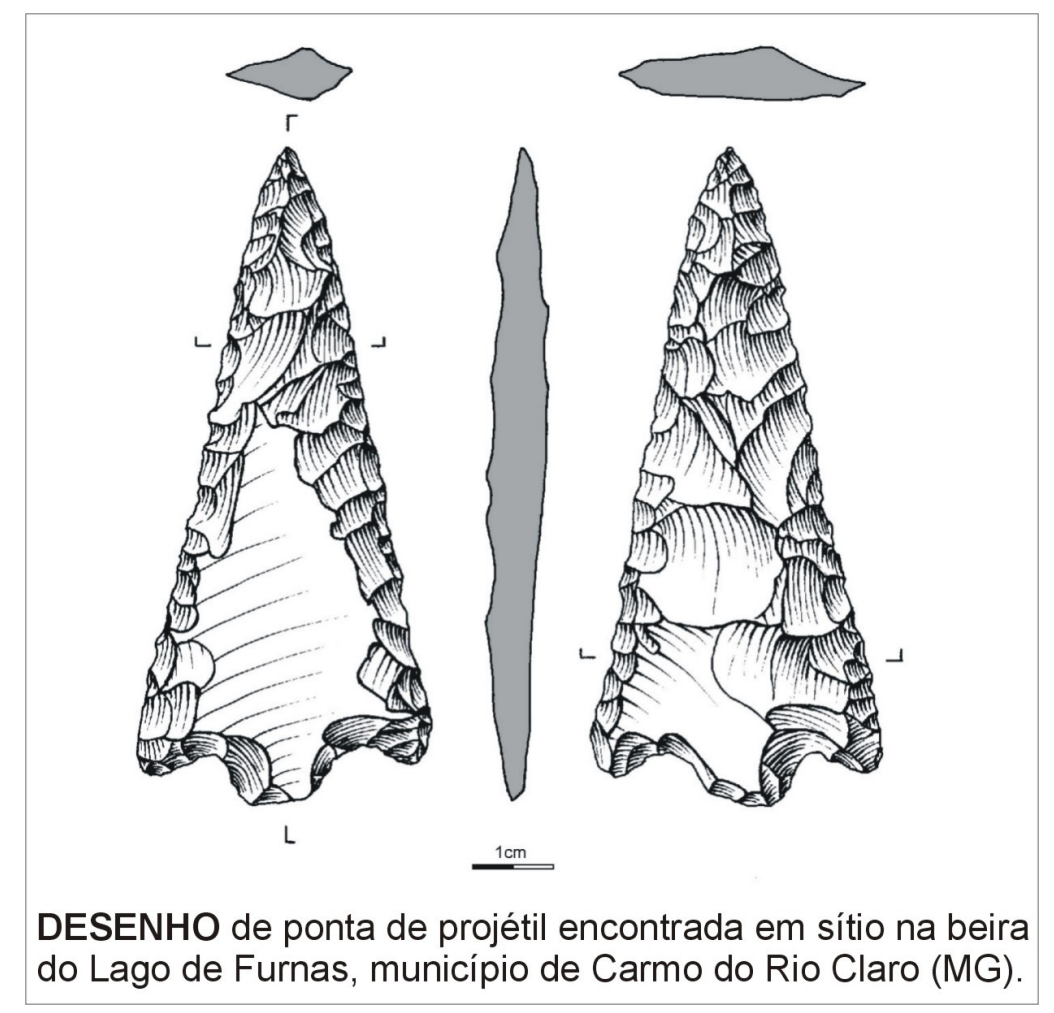

Apesar do término deste projeto de mestrado, as escavações do setor Esc. 3 ainda não foram totalmente concluídas, o que deve acontecer no final do ano corrente. Acredito que estudos mais abrangentes sejam necessários para dar frente aos novos problemas levantados, principalmente no que concerne à possível presença da tradição Umbu no centro-oeste do estado de Minas Gerais ${ }^{40}$.

Trata-se aqui de um trabalho em uma região rica em vestígios arqueológicos, mas que, até pouco tempo, estava relegada ao esquecimento acadêmico. Por ser uma pesquisa inicial ainda desconhece-se o significado real que as descobertas aqui apresentadas representam para o quadro arqueológico regional que, originárias principalmente de dois sítios arqueológicos, a Loca do Suim e a Gruta do Marinheiro, são ainda pouco representativas para a região cárstica como um todo.

observado na Gruta do Marinheiro.

${ }^{40}$ Caso confirmado seria a expressão mais setentrional conhecida dessa tradição. 


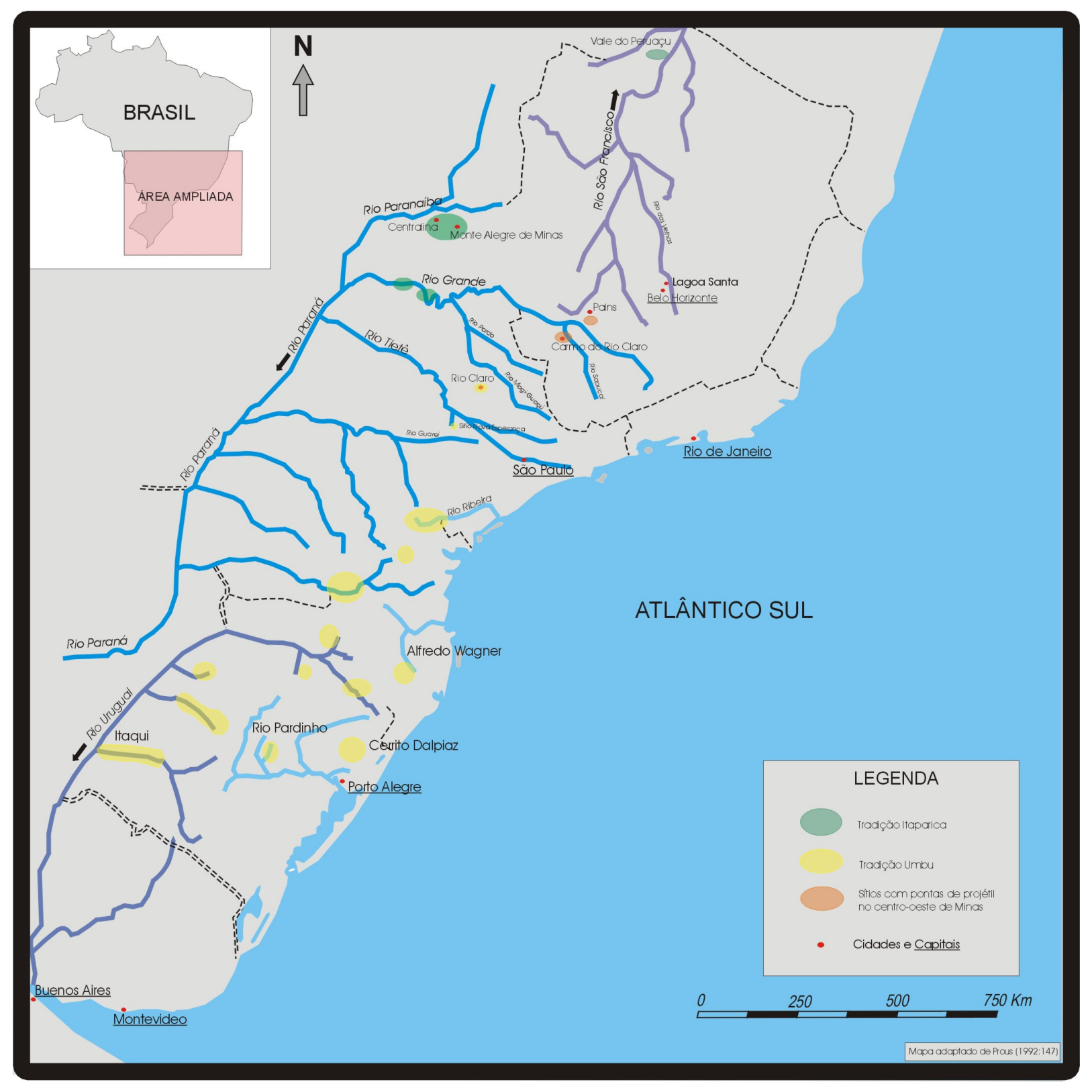




\section{BIBLIOGRAFIA}

ALKMIM, F.F. \& MARTINS-NETO, M.A.

2001 A bacia intracratônica do São Francisco: arcabouço estrutural e cenários evolutivos, In: PINTO, C.P. \& MARTINS-NETO, M.A. (org.), Bacia do São Francisco: geologia e recursos naturais, Cap.II, Belo Horizonte: SBG/MG, pp.9-30.

ANDREFSKY JR, William.

2001 Emerging Directions in Debitage Analysis, Lithic Debitage: Context, Form, Meaning, The University of Utah Press, Salt Lake City, pp. 2-14.

ANDREFSKY JR, William

1998 Lithics: Macroscopic Approaches to Analysis, Cambridge University Press, Cambridge (UK), 258p.

ARAÚJO, A.G.M. et alii

2005 Holocene dryness and human ocupation in Brazil during the "Archaic Gap", Quartenary Research, 64: 298-307.

BAHN, Paul e RENFREW, Colin

1996 Archaeology: Theories, Methods and Practice, Thames and Hudson Ltd, London.

BARBOSA, Altair Sales,

1995 Peregrinos do Cerrado, Revista do Museu de Arqueologia e Etnologia, 5:159-193, São Paulo.

BIGARELLA, BECKER e SANTOS

1996 Estruturas e origem das paisagens tropicais e subtropicais vol. 2, Ed. UFSC, Florianópolis.

BINFORD, Lewis R.

1981 Behavioral Archaeology and the "Pompeii Premise", Journal of Anthropological Research, Vol.37, numb.3, The University of New Mexico, pp.195-208.

1980Willow Smoke and Dogs' Tails: Hunter-Gatherer Settlement Systems and Archaeological Site Formation, American Antiquity, vol. 45 n 11, pp.4-20.

BALFET, H. (org.)

1991 Observer l'action technique. Des chaines opératoires, pour quoi faire? Paris: CNRS.

BLEED, P.

1986 The Optimal Design of Hunting weapons: Maintainability or Reliability, American Antiquity, 51(4), pp.737747.

BRASIL,

1983 Ministério das Minas e Energia. Secretaria Geral, Projeto RADAMBRASIL, Folha SF-24, Rio de Janeiro/Vitória; geologia, geomorfologia, pedologia, vegetação e uso potencial da terra, Rio de Janeiro, 780p. il. 5mapas (Levantamento de Recursos Naturais v.32)

BUENO, L.M.R.

2005 Variabilidade tecnológica nos sítios líticos do Lajeado, médio rio Tocantins, Programa de Resgate Arqueológico da UHE Lajeado, estado de Tocantins - Relatório Final, Vol. III, Tese de Doutorado, Museu de Arqueologia e Etnologia da Universidade de São Paulo, São Paulo.

CALDARELLI, Solange B.

1983 Lições da Pedra, Tese de Doutoramento em História Social, São Paulo.

CARR, Philip J. \& BRADBURY, Andrew P.,

2001 Flake Debris Analysis, Levels of Production and the Organization of Tecnology, Lithic Debitage: Context, Form, Meaning, The University of Utah Press, Salt Lake City, pp.126-146.

CLARKE, Davis L.

1977 Spatial Information in Archaeology, Spatial Archaeology, Academic Press, London, pp. 1-31.

COELHO, Marcos de Amorim

1995 Geografia do Brasil, Editora Moderna Ltda., São Paulo.

COSTA, Fernando

1998 A Academia Mineira de Ciências, monografia de graduação, UFMG.

CPRM - Companhia de Pesquisa de Recursos Minerais / IBAMA - Instituto Brasileiro do Meio Ambiente,

1998 Zoneamento Ambiental da APA Carste de Lagoa Santa.

DE BLASIS, Paulo

1989 A Indústria dos Sítios Líticos do Médio Vale do Ribeira de Iguape: Um Ensaio Tipológico, Revista PréHistória, São Paulo, 7:89-111.

DIAS, Adriana Schmidt

2003 Sistemas de Assentamento e Estilo Tecnológico: Uma Proposta Interpretativa para a Ocupação Précolonial do alto Vale do Rio Sinos, Rio Grande do Sul, Tese de Doutorado, Faculdade de Filosofia, Letras e Ciências Humanas da Universidade de São Paulo.

1994 Repensando a Tradição Umbú a Partir de um Estudo de

Caso, Dissertação de Mestrado, Pontifícia Universidade Católica do Rio grande do Sul, Porto Alegre.

DIAS Jr., Ondemar

1993 As origens da horticultura no Brasil, Revista de Arqueologia Americana, São Paulo, v.7, pp. 7-52. 
1990 Linha de Pesquisa: Adaptações das populações pré-históricas nos diversos ecossistemas brasileiros, CLIO, Série Arqueológica, Recife, Universidade Federal do Pernambuco, v.1, 꾸, pp.127-128.

1975 A fase Piumhí - seu reconhecimento arqueológico e suas relações culturais, Tese de livre docência, Universidade Federal do Rio de Janeiro, Rio de Janeiro.

1975 Pesquisas Arqueológicas no Sudeste Brasileiro, Boletim do Instituto de Arqueologia Brasileira, Série Especial - N.1, Rio de Janeiro.

1974 Nota prévia sobre as pesquisas arqueológicas em Minas Gerais, PRONAPA, Resultados Preliminares do 5 Ano, 1969-1970, Belém, Museu Paraense Emílio Goeldi, Publicações Avulsas, no 26, pp. 105-116.

1971 Breve notas a respeito das pesquisas no sul de Minas Gerais, PRONAPA, Resultados Preliminares do $4^{\circ}$ ano, 1968/1969, Belém, Museu Paraense Emílio Goeldi, Publicação Avulsas, no 15, pp. 133-148.

DIAS Jr, Ondemar e CARVALHO, E.T.

1982 A Fase Piumhy: seu reconhecimento arqueológico e suas relações culturais, CLIO, Recife, Universidade Federal de Pernambuco, v.5, pp.5-43.

1981/82 Discussão sobre os inícios da agricultura no Brasil, Arquivos do Museu de História Natural da UFMG, Belo Horizonte, v.6/7, pp.191-200.

DILLEHAY, Thomas

2000 The Settlement of the Americas, Basic Books, New York.

ESCHWEGE, W.L. von

1979 Ocorrência salíferas e de combustíveis: salitre, Pluto Brasiliensis, $2^{\circ}$ vol., Belo Horizonte: Ed. Itatiaia, São Paulo: Ed. USP, 1979, pp.189-194.

EVANS, C. \& MEGGERS, B.J.

1965 Guia para a Prospecção Arqueológica no Brasil, Museu Paraense Emílio Goeldi, Belém, 63p.

FIEDEL, S.J.

1996 Prehistoria de America, CRÍTICA (Grijalbo Mondadori, S.A.), Barcelona.

FOGAÇA, E.

2001 Mãos para o pensamento, Tese de doutorado, Pontifícia Universidade Católica do Rio Grande do Sul, Porto Alegre.

1995 A tradição Itaparica e as indústrias líticas pré-cerâmicas da Lapa do Boquête (MG-Brasil). Revista do Museu de Arqueologia e Etnologia. São Paulo, pp 145-158.

GAMBLE, Clive

1990 El Poblamento Paleolítico de Europa, Editorial Crítica, Barcelona.

GONZALES-JOSÉ, R. et alii,

2005 Late Pleistocene/Holocene Craniofacial Morphology in Mesoamerican Paleoindians: Implications for the Peopling of the World, American Journal of Physical Anthropology, 128:772-780.

GRUPO BAMBUÍ DE PESQUISAS ESPELEOLÓGICAS - BRASIL, O CARSTE, Edição Especial: Bicentenário 2002 do nascimento de Peter Wilhelm Lund.

GUERRA, A.T.

1969 Dicionário Geológico-Geomorfológico, Fundação IBGE, Rio de Janeiro.

HADDAD, Eduardo Abjaud,

2006 Relações entre atividades humanas e qualidade da água na bacia hidrográfica do rio São Miguel, Carste do Alto São Francisco, Minas Gerais, Dissertação de Mestrado, Instituto de Geociências da Universidade Federal de Minas Gerais - IGC/UFMG, Belo Horizonte.

HENRIQUES JR, Gilmar

2006 Arqueologia Regional do Rio São Miguel, Bacia do Alto São Francisco: Cronologia das Ocupações Una e Sapucaí, Tese de Mestrado, Museu de Arqueologia e Etnologia - USP, São Paulo.

HENRIQUES JR, G., COSTA, F. e KOOLE, E.

2001 Análise tecnológica do material lítico de um sítio de caçadores-coletores localizado na "Província Cárstica de Arcos-Pains-Doresópolis", Minas Gerais. Anais do XI Congresso da Sociedade de Arqueologia Brasileira, Rio de Janeiro, no prelo.

HURT, W.,

1987 Tradition Itaparica, Revista Clio, Série Arqueológica n.5, Universidade Federal de Pernambuco, 55-58. The cultural complexes from the Lagoa Santa Region, American Anthropologist, vol.6.

HURT, Wesley e BLASI, Ondemar

1969 O Projeto Arqueológico "Lagoa Santa"- Minas Gerais, Brasil (Nota Final), Arquivos do Museu Paranaense - Nova Série, no4, Curitiba, 1-59.

JUNQUEIRA, Paulo,

1984 O Grande Abrigo Santana do Riacho: Abrigo com Sepultamentos no Estado de Minas Gerais V.1, Dissertação de Mestrado em Antropologia Social (Arqueologia), Departamento de Ciências Sociais da Faculdade de Filosofia, Letras e Ciências Humanas da Universidade de São Paulo.

KIPNIS, R.

2002 Foraging Societies of Eastern Central Brazil: An Evolutionary Ecological Study of Subsistence Strategies During the Terminal Pleistocene and Early/Middle Holocene, Ph.D. Dissertation, University of Michigan

1993 Early hunter-gatherers in the Americas: perspectives from central Brazil, Antiquity, vol. 72, no 277, pp. 581592. 
KOOLE, Edward., HENRIQUES Jr, Gilmar \& COSTA, Fernando

2001 Archaeology and Caves in the Carstic Province of Arcos - Pains - Doresópolis, Minas Gerais- Brazil. The $13^{\text {th }}$ International Congress of Speleology - Speleo Brazil 2001, Brasília.

KOHLER, H.C.

1989 Geomorfologia Cárstica na Região de Lagoa Santa - MG, Tese de Doutoramento, FFLCH/Departamento de Geografia/USP, São Paulo.

KRIEGER, Alex D.

1944 The Typological Concept, American Antiquity, 3, pp.271-288.

LAMING-EMPERAIRE et alii

1972/73 Grottes e Abris de la Region de Lagoa.Santa, Minas Gerais, Brésil, Cahiers d'Archéologie d'Amerique du Sud, n¹-2, École Pratique des Hautes Études VI Section Sciences Économiques et Sociales.

LANATA, José Luis

1993 Evolución, Espacio y Adaptación en Grupos Cazadores-Recolectores, Revista do Museu de Arqueologia e Etnologia, USP, São Paulo, pp. 3-15.

LEE \& DEVORE,

1977 Man the Hunter, pp.11-12.

LEROI-GOURHAN, André

1988 Dictionnaire de la Préhistoire, Presses Universitaires de France, Paris.

1981 Pré-história, EDUSP, São Paulo, pp. 218-253.

LIMA, André Penin Santos de,

2005 Análise dos processos formativos do sítio Capelinha: estabelecimento de um contexto microregional, Dissertação de mestrado, Museu de Arqueologia e Etnologia da Universidade de São Paulo MAE/USP

MACHADO, L.C.,

1990 Sobre as práticas funerárias de cremação e suas variações em grutas do norte e noroeste de Minas Gerais, Revista do CEPA, Anais da V Reunião Científica da Sociedade de Arqueologia Brasileira - SAB, vol.17, n.20, Santa Cruz do Sul/RS, pp.235-245.

MATTOS, Anibal

1961 O Homem das Cavernas de Minas Gerais, Editora Itatiaia Ltda, Belo Horizonte.

MONTEIRO, Alacrino,

1939 Serviço Geográfico de Minas Gerais, As Grutas de Minas Gerais, Imprensa Oficial. Belo Horizonte

MORAIS, José Luiz

1987 À Propósito do Estudo das Indústrias Líticas, Revista do Museu Paulista, nova série, vol. XXXII.

MORALES, W. F.,

200512.000 anos de ocupação: um estudo de arqueologia regional na bacia do córrego Água Fria, médio curso do rio Tocantins, Tese de Doutorado, Museu de Arqueologia e Etnologia, Universidade de São Paulo, São Paulo.

NEVES, W.A. \& HUBBE, M.,

2005 Cranial morfology of early Americans from Lagoa Santa, Brazil: Implications for the settlement of the New World, PNAS, vol.102, no. 51.

ODELL, George H. (ed.)

1996 Stone Tools: Theoretical Insights into Human Prehistory, Plenum Press, New York.

PALLESTRINI, L. CHIARA, P.

1987 Indústria Lítica de Camargo, Município de Piraju, Estado de São Paulo, Coleção Museu Paulista, série ensaios, vol.2, USP, São Paulo.

PIZARRO, A. P.

1998 Compartimentação geológica-geomorfológica da Província Carbonática-Espeleológica de Arcos, Pains e Doresópolis, Anais do XL Congresso Brasileiro de Geologia, Belo Horizonte, SBG, pp.421 (resumo)

PIZARRO, Alexandre, FRIGO, Fernando e CAMPELLO, Marcos

2001 Updating the caves distribution of Arcos-Pains-Doresópolis Speleologic-Carbonatic Province, The 13 ${ }^{\text {th }}$ International Congress of Speleology - Speleo Brazil 2001, Brasília.

POHL, Johann Emanuel

1976 Viagem no Interior do Brasil, Editora da Universidade de São Paulo, Livraria Itatiaia Editora Ltda., pp.9293

PROUS, André

1999 As Primeiras Ocupações do Estado de Minas Gerais, Pré-História da Terra Brasilis, Editora UFRJ, Rio de Janeiro, pp.101-114

1996/1997 Résumé: Archéologie du Cours Moyen du Rio São Francisco (Vallées des Rios Peruaçu e Cochá), Arquivos do Museu de História Natural da UFMG. Vol. XVII/XVIII, Belo Horizonte: UFMG, pp. 19-67.

1996/1997 Princípios para a descrição das indústrias líticas do Alto-Médio São Francisco. Arquivos do Museu de História Natural da UFMG. Vol. XVII/XVIII, Belo Horizonte: UFMG, pp. 127-138.

1992 Arqueologia Brasileira, Editora Universidade de Brasília, Brasília.

1986/1990 Os artefatos líticos, elementos descritivos classificatórios. Arquivos do Museu de História Natural da UFMG. v.11 Belo Horizonte: UFMG, pp.1-90.

PROUS, A. \& FOGAÇA, E. 
1999 Archaeology of the Pleistocene-Holocene boundary in Brazil, Quarternary International, 53/54, pp. 21-42. ROUSE, Irving

1960 The Classification of Artifacts in Archaeology, American Antiquity, vol.25, n³, pp.313-323.

SCHMITZ, Pedro Inácio

1991 Áreas arqueológicas do litoral e Planalto do Brasil, Revista do Museu de Arqueologia e Etnologia, São Paulo, Universidade de São Paulo, v.1, pp.3-20.

1991 O mundo da caça, da pesca e da coleta, Pré-história do Rio Grande do Sul, Documentos 05, Instituto Anchietano de Pesquisas, UNISINOS, São Leopoldo/RS, pp.9-29.

SCHICK, Kathy D. e TOTH, Nicolas

1994 Making Silent Stones Speak, Simon \& Schuster TOUCHSTONE EDITION, New York, London, Toronto, Sydney, Tokyo, Singapore.

SCHIFFER, M.B.

1976 Cultural Formation Processes, Behavioral Archaeology, pp. 27-41.

1972 Archaeological Context and Systemic Context, American Antiquity, 37(2), pp.156-165.

TIXIER, J. et alii

1981 Préhistoire de la Pierre Taillée: terminologie e technologie, Paris, CREP.

VAN HORN, David M. \& MURRAY, John R.

19933 Transit-Controlled Surface Collecting, Practical Archaeology Field \& Laboratory Techniques: an WALTER, H.V. Archaeological Logistic, Los Angeles: UCLA.

1948 The Pre-History of the Lagoa Santa Region (Minas Gerais), Velosso \& Cia. Ltda., Belo Horizonte.

WALTER, H.V.

1958 Archaeology of the Lagoa Santa Region (Minas Gerais), SEDEGRA, Rio de Janeiro.

WILLEY, G. \& PHILLIPS, P.

1958 Method and theory in american archaeology, University of Chicago Press, Chicago, $269 \mathrm{p}$.

WHITTAKER, John C.

1994 Flintknapping: Making and Understanding Stone Tools, University of Texas Press, Austin. 
ANEXO 


\section{LABORATÓRIO DE ESTUDOS EVOLUTIVOS HUMANOS \\ DEPARTAMENTO DE GENÉTICA E BIOLOGIA EVOLUTIVA - IBUSP}

\author{
RELATÓRIO DE CURADORIA \\ ESQUELETOS DA LOCA DO SUIM \\ PAINS-MG
}

INÍCIO DA CURADORIA: 01 DE ABRIL 2006 TÉRMINO DA CURADORIA: 20 DE JUNHO DE 2007

RESPONSÁVEIS: ANDRÉ MENEZES STRAUSS PEDRO JOSÉ TÓTORA DA GLÓRIA

COLABORADORES: TATIANE LEITE NUNES RODRIGO ELIAS DE OLIVEIRA

Introdução

Os remanescentes ósseos que foram curados haviam sido recuperados durante as escavações do sítio arqueológico Loca do Suim, localizado na região de Pains, em Minas Gerais. Este material foi dividido pelos arqueólogos em dois sepultamentos: sepultamento I e sepultamento II. Os diversos fragmentos de ossos estavam guardados dentro de sacos plásticos junto a etiquetas de identificação nas quais constavam o número de escavação, o número do sepultamento e uma descrição de campo do material. O processo de curadoria foi feito individualmente para cada um dos sepultamentos.

O procedimento de curadoria seguiu os passos propostos por Neves (1988). Antes do material ser lavado e restaurado foi observada a coloração, estabelecida através de uma tabela Munsell, dos sedimentos que recobriam os ossos. Em seguida, os ossos foram limpos com o auxílio de uma escova de dentes umidecida. Em alguns casos, a presença de concreções carbonáticas demandou a aplicação de ácido acético em concentração de 4\%. Uma vez secos, os ossos foram então remontados, utilizando-se fita adesiva e cola solúvel em água. 
Infelizmente, o péssimo estado de preservação do material não permitiu que porções consideráveis do esqueleto fossem reconstituídos.

Como consequência, o material curado não pôde ser plenamente estudado, quer fosse do ponto de vista antropométrico, quer do paleopatológico. Mesmo a determinação de sexo e idade ficou comprometida pela má preservação dos ossos e, assim como os breves comentários sobre patologias, deve ser vista com um certo grau de incerteza. Além disso, o estado de conservação dos crânios não permitiu, para nenhum dos dois sepultamentos, análises de afinidade biológica.

Ambos os sepultamentos foram datados através do método AMS feito sobre costelas. As idades convencionais para os Sep-I e Sep-II foram, respectivamente, 7.440 \pm 50 BP (BETA210400) e 7.530 \pm 50 BP (BETA-210401). As idades calibradas são, respectivamente, 8160-8360 BP e 8200-8400 BP.

\section{Sepultamento I}

Os sedimentos que recobriam os ossos deste sepultamento eram bastante heterogêneos em suas cores. O sedimento que recobria a pélvis, a diáfise do fêmur, os molares, as epífises dos ossos longos, os fragmentos de crânio e os fragmentos de vértebras era de cor avermelhada (2YR 5/6). O sedimento que recobria a cabeça do fêmur, o úmero, a ulna, os metatarsos, as costelas e alguns fragmentos de crânio era de cor marrom (5YR 4/4). Outros fragmentos do crânio e ossos longos estavam recobertos por sedimento de cor acinzentada (7,5YR 6/2 e 5YR 5/1).

Os ossos foram exumados como um único sepultamento, mas quando analisados em laboratório percebeu-se que o número mínimo de indivíduos presentes neste sepultamento é quatro. Dois deles estão melhor representados, tendo sido preservados partes consideráveis do crânio, dos ossos longos, dos dentes e dos ossos da mão e do pé. Desses dois, um está intensamente cremado enquanto o outro não sofreu qualquer influência do fogo. Denominamos esses indivíduos, respectivamente, de Sep - IA e Sep - IB. Juntos, eles são responsáveis por mais de $90 \%$ dos ossos do Sep-I. Os demais indivíduos estão representados por pouquíssimas partes anatômicas. Um deles é uma criança de cerca de 5 anos, que está bem representada pelos dentes, um úmero e um

temporal esquerdo, nenhum deles cremados. Foi denominado Sep-IC. O outro, Sep-ID é uma criança, possivelmente um recém-nascido, do qual apenas metade de um úmero queimado e um talus foram identificados.

Entretanto, não é possível definir com total segurança a qual desses indivíduos cada fragmento de osso pertence. Em casos de grandes fragmentos, a distinção entre indivíduos é 
mais fácil. Claro que ossos nitidamente adultos não puderam ser atribuídos a nenhum dos indivíduos jovens. De modo geral, entretanto, os principais ossos foram separados com segurança entre os quatro indivíduos.

Além disso, os ossos do Sep-I estavam particularmente fragmentados e formavam, nitidamente, dois grupos: um de ossos queimados e outro de ossos não queimados. Esta divisão acompanha a dos quatro indivíduos, sendo que os Sep-IB e Sep-ID foram queimados enquanto que os Sep-IA e o Sep-C não o foram. Assim, outro critério que foi utilizado para endereçar os fragmentos foi se o osso estava queimado ou não. Se o osso estivesse cremado e não tivesse sido identificado como sub-adulto, ele foi designado como Sep-IB. No caso do fragmento não apresentar nenhum sinal de queima e não ser classificado como sub-adulto, ele foi designado como SEP-IA. É claro que esta não é uma solução ideal já que fragmentos não queimados podem pertencer também ao indivíduo que foi cremado. Essa afirmação pode ser atestada pela presença de grupos de ossos (mesma localização espacial no sítio arqueológico) que apresentam tanto fragmentos queimados como não queimados, da mesma forma que há fragmentos de ossos apenas parcialmente queimados (e.g. crânio). Portanto, é preciso ter em mente que a assignação dos fragmentos foi feita sobre bases aproximadas e, por isso, sujeita a falhas. Ainda assim, no que diz respeito aos ossos mais bem preservados, parece que a separação entre os quatro indivíduos pode ser tomada como bastante sólida.

As principais partes anatômicas preservadas do Sep-IA (Figura. 1) são: região posterior do crânio, incluindo fragmento de ambos os parietais e do occipital; regiões petrosas dos temporais de ambos os lados; região articular da escápula direita; metade medial da clavícula esquerda; úmero esquerdo sem epífise distal; fragmentos de cerca de $5 \mathrm{~cm}$ de diáfise do úmero direito; porção distal do rádio esquerdo; vértebras cervicais; fragmento de ílio esquerdo; epífese proximal de fêmur direito, fêmur esquerdo quase completo; metade proximal da fíbula direita; tarsos; metatarsos e todos os dentes.

Nenhuma parte anatômica que permitisse a estimação de idade foi encontrada no SepIA. Ainda assim, a presença do terceiro molar atesta que se trata de um indivíduo adulto. Aplicando-se o método de estimação de idade baseado no grau de desgaste dentário (Lovejoy, 1985) estimou-se uma idade entre 16 e 20 anos para este indivíduo, o que é confirmado pelo baixo grau de fusionamento das suturas coronal e sagital. Na ausência de partes anatômicas mais confiáveis, a estimação do sexo (masculino) foi feita a partir da observação do ângulo lateral do meatus auditivo interno da região petrosa do temporal (Figura. 2). O estado fragmentário dos ossos longos não permitiu que fossem feitas estimativas de estatura. Com relação às patologias, ressalta-se a presença de osteofitose nas vértebras cervicais. Na terceira vértebra cervical há um agravamento da condição, com formação de osteófitos, tanto na margem superior como na inferior. Nas demais vértebras cervicais o grau da osteofitose é 
moderado, sem formação de osteófitos (Figura. 3). Também há uma leve osteoartrite na face articular proximal do halux esquerdo. Há presença de marcante torus auditivo (exostose) em ambos os canais auditivos (Figura. 4). 


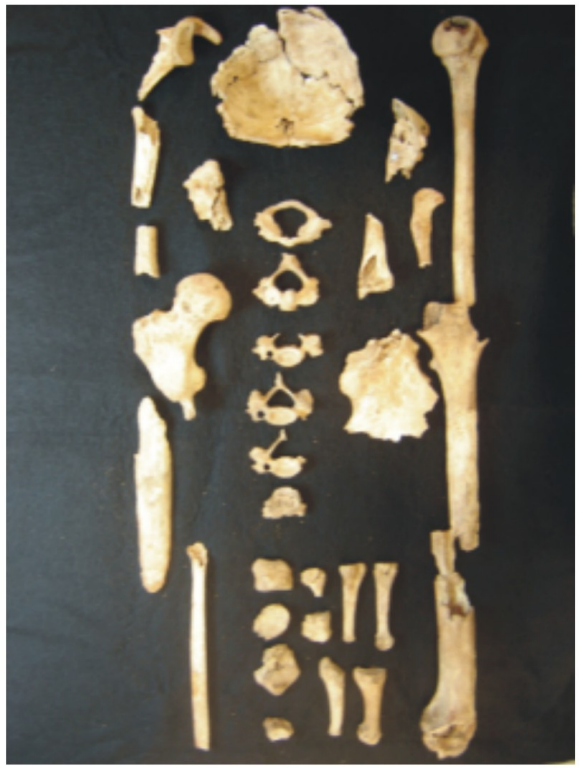

Figura 1 - Sepultamento IA e seus principais ossos
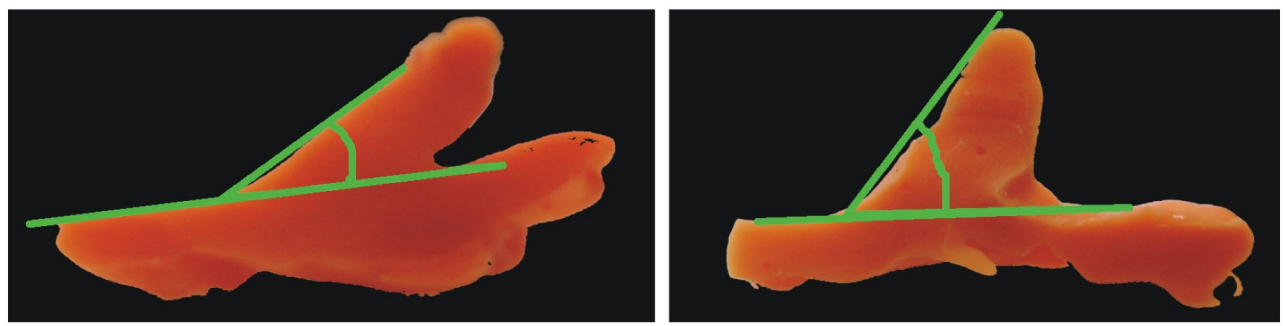

Figura 2. Sessões longitudinais de moldes feitos em silicone do chamado "ângulo lateral". O ângulo lateral é formado pela parede externa posterior e interna lateral do meato auditivo interno que se localiza na parte petrosa do osso temporal. A imagem da esquerda corresponde ao Sep-IA e a da direita ao Sep-IB. É possível verificar visualmente que o ângulo formado pelas retas verdes, que formam o ângulo lateral, é bem menor no Sep-IA do que no Sep-IB, indicando, respectivamente, indivíduos do sexo masculino e feminino.

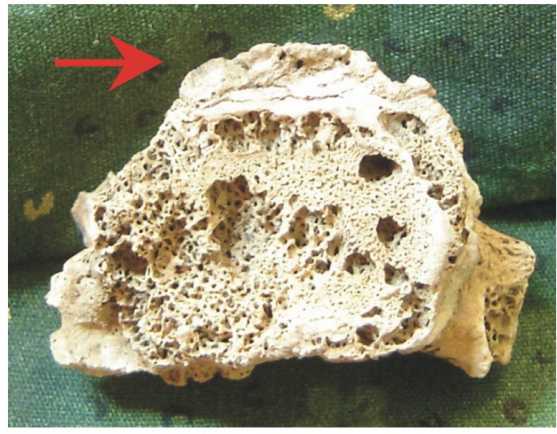

Figura 3 - Sep IA, osteofitose acentuada na margem dorsal de uma vértebra cervical.

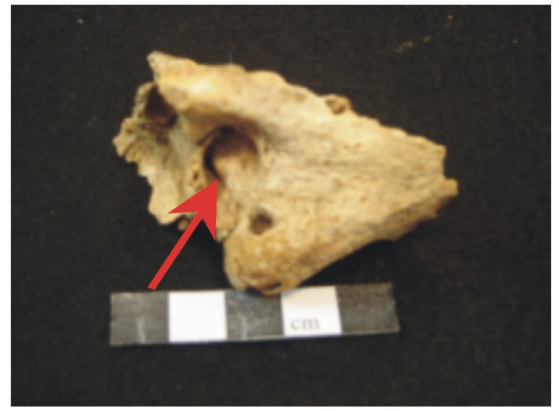

Figura 4 - Sep IA, torus auditivo no meato acústico externo. 
Os seguintes dentes do Sep-IA estão presentes: todos molares com excessão do terceiro molar superior esquerdo e os dois segundo molares superiores (Figura. 5). Há presença de cárie no terceiro molar inferior esquerdo (Figura. 6).

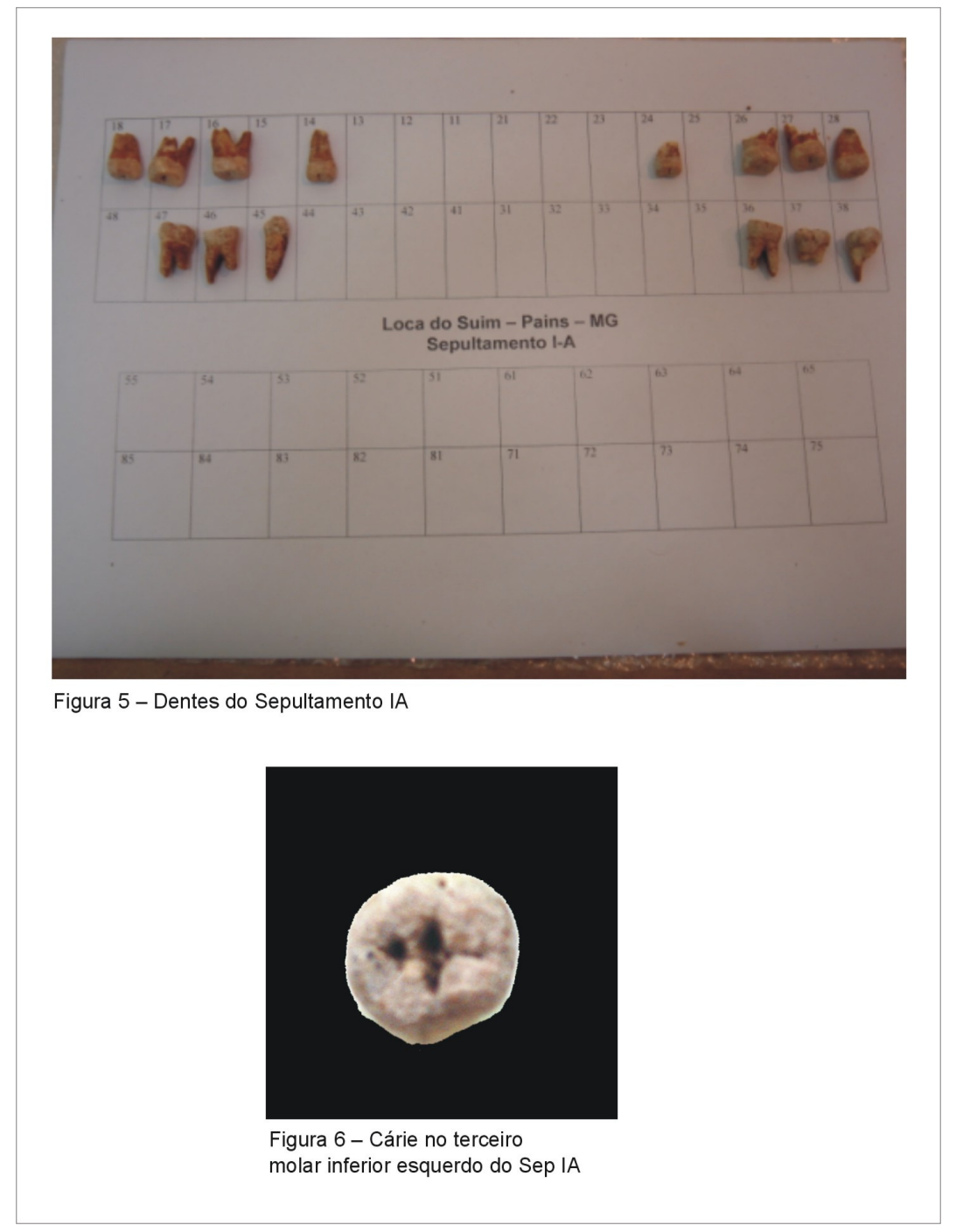

O Sep-IB (Figura. 7) está representado por ossos do crânio, mandibula, clavícula, úmero, rádio, tíbia, fêmur, ossos de mão e ossos de pé. Entretanto, devido à queima a que foram submetidos, os ossos do Sep-IB estão extremamente fragmentados, impedindo qualquer tentativa confiável de estimação de sexo, idade e estatura. O padrão transversal de fraturas presente nas diáfises dos ossos longos (Figura. 8) indica que estes ainda estavam frescos quando foram cremados. As regiões que foram mais poupadas do processo de queima são o calvário, a manbíbula, a região da glenóide escapular e alguns ossos do pé. A cor dos ossos vai desde o branco intenso (Gley 2) até a cor natural, passando por níveis escuros (5Y 2,5/1) e 
amarronzados (Fig. 9); portanto, estão presentes todos os graus de queima propostos por Stiner e Kuhn (1995).

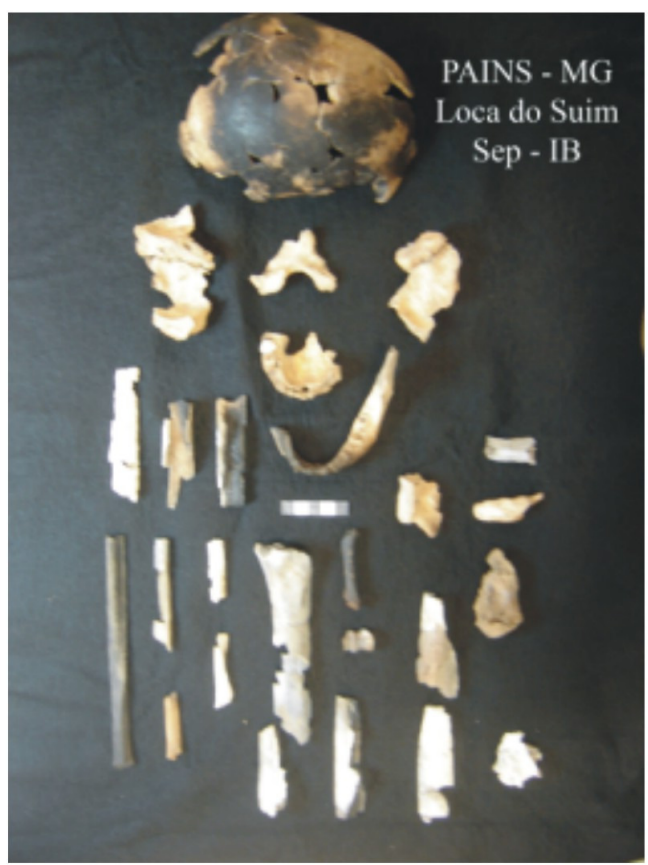

Figura 7 - Sepultamento IB e seus principais ossos.

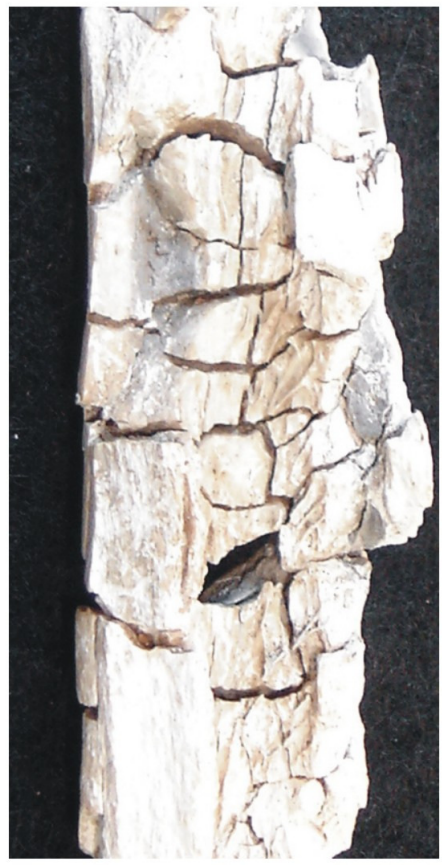

Figura 8 - Sepultamento IB, fraturas transversas e longitudinais em diáfise de osso longo geradas por queima.

A presença do terceiro molar, somada com o alto grau de desgaste dos dentes e do alto grau de fusionamento da sutura coronal, sugerem tratar-se de um adulto maduro. Aplicando-se o método de estimação de idade baseado no grau de desgaste dentário (Lovejoy, 1985) estimou-se uma idade entre 45 e 55 anos para este indivíduo. Na ausência de partes anatômicas mais confiáveis, a estimação do sexo foi feita a partir da observação do ângulo lateral do osso petroso, segundo o qual se trata de um indivíduo do sexo feminino (Figura 2). Assim como no Sep-IA foram observados torus auditivos acentuado em ambos os meatos auditivos externos (Figura 10). Numa vértebra toráxica, ocorre formação marcante de osteófito. Há presença de osteoartrite na fossa glenóide direita (Fig. 11).

Apenas quatro dentes do Sep IB foram recuperados sendo que dois deles não estavam no alvéolo. Todos são molares. 


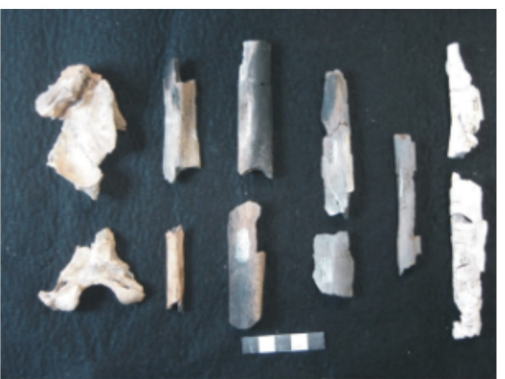

Figura 9 - Ossos do sepultamento IB

mostrando distintos graus de

cremação. No extremo esquerdo, osso

não queimado e no direito, osso

calcinado. Entre eles estão os estágios

intermediários.

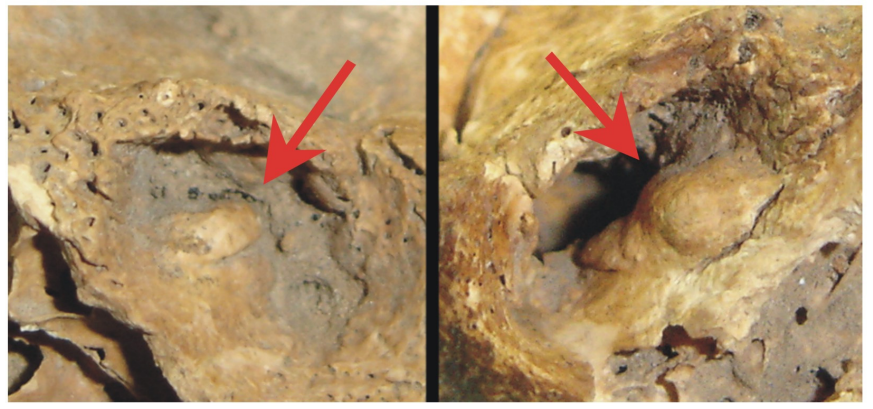

Figura 10 - Sepultamento IB, meato auditivo externo com presença detorus auditivo acentuado (exsostose). As fotos da esquerda e da direita correspondem,

respectivamente aos temporais esquerdo e direito, ambos vistos em norma lateral.

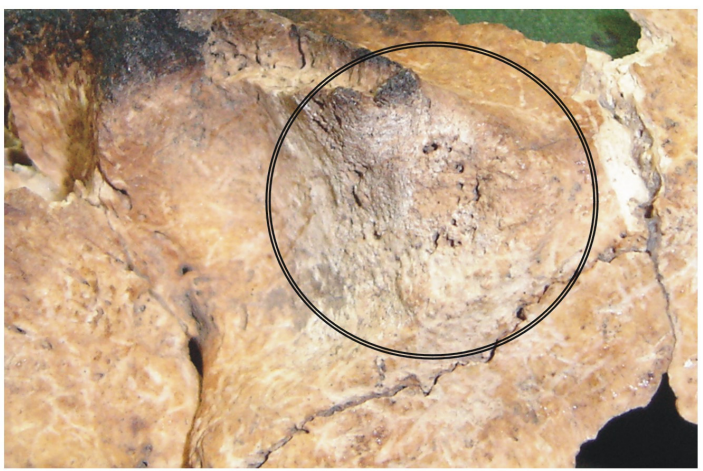

Figura 11 - Sepultamento IB, osteoartrite na região anterior da fossa da glenóide do temporal direito.

O Sep-IC (Figura. 12) foi definido como o indivíduo representado por um conjunto de dentes permanentes e decíduos que sugerem idade de 5 anos. Apenas outros dois ossos foram identificados como compatíveis com este indivíduo. Um deles é um úmero cujo tamanho estimado da diáfise é de $17 \mathrm{~cm}$. Segundo os dados disponíveis na literatura, este comprimento corresponde a um indivíduo entre 4,5 e 5 anos de idade. O outro osso que foi atribuido ao SepIC é um temporal esquerdo. É importante notar que o desenvolvimento ósseo da região petrosa do temporal termina quase que completamente aos quatro anos e meio. $\mathrm{O}$ fim desse processo de desenvolvimento é marcado eventualmente pelo fechamento, na placa timpânica, do forâme de Huschke. Como o temporal em questão não apresenta este forâme, ele pertence à um indivíduo com pelo menos quatro anos e meio de idade. Por isso, mesmo com uma morfologia aparentemente "adulta", este temporal é absolutamente compatível com um indivíduo de 5 
anos. O fato do desenvolvimento ósseo da região petrosa terminar tão cedo torna o método de estimação de sexo pelo ângulo lateral do osso petroso viável mesmo em indivíduos juvenis. Por isso, e devido a ausência de partes anatômicas mais confiáveis, a estimação do sexo foi feita a partir da observação do ângulo lateral. Os resultados apresentaram valores intermediários entre masculino ou feminino. Entretanto, é preciso cautela com esta estimação, pois não só o valor observado do ângulo lateral está no limite entre os sexos como a confiabilidade desse método para juvenis ainda está em discussão. Eventuais fragmentos pequenos de ossos de crânio deste indivíduo podem ter sido indevidamente atribuídos ao Sep-IA.

No Sep-IC estão presentes tanto dentes permanentes como dentes de leite. Dentre os dentes de leite estão presentes: dois incisivos centrais superiores, canino superior direito, segundo molar superior esquerdo e os quatro molares inferiores. Dentre os dentes permanentes estão presentes: os quatro incisivos superiores, o canino superior esquerdo, os oito pré-molares, primeiro e segundo molar superior esquerdo, incisivo central inferior direito, dois primeiros molares inferiores e um segundo molar inferior direito (Figura 13). 


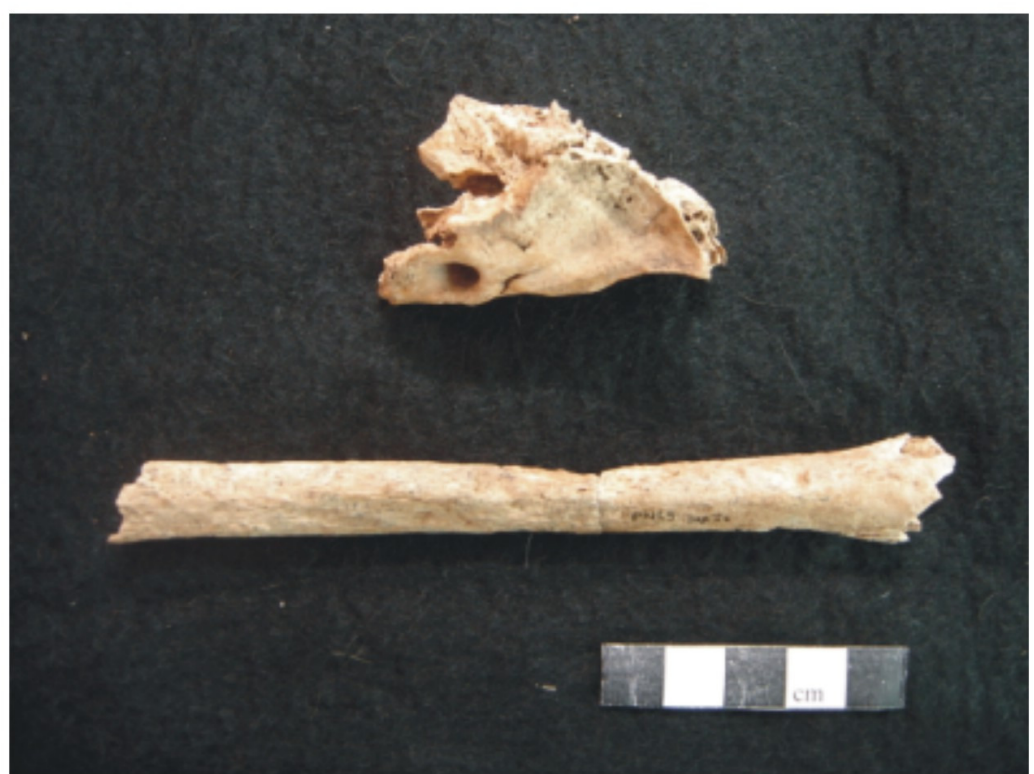

Figura 12 - Sepultamento IC, temporal esquerdo e úmero de um indivíduo de cerca de 5 anos.

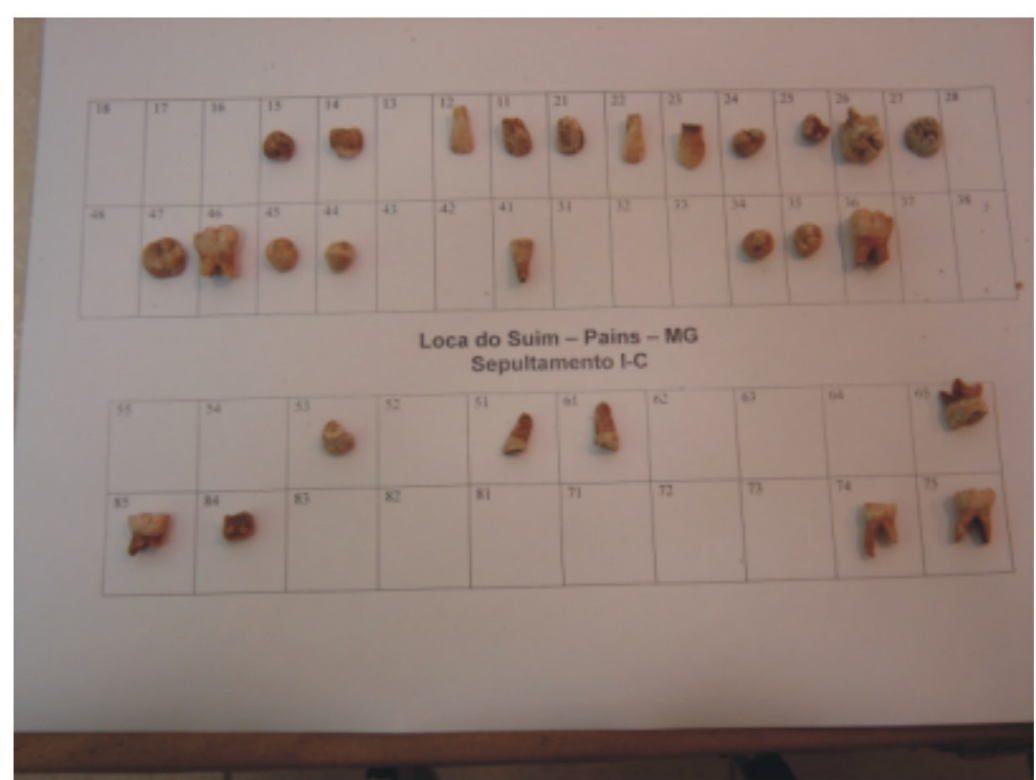

Figura 13 - Dentes do Sepultamento IC

O Sep-ID está representado por um fragmento distal de úmero (Figura. 14) e um talus direito. Este fragmento foi queimado, mas não calcinado, já que apresenta cor de marrom escura a preta. O tamanho deste fragmento indica que este é um indivíduo muito jovem, provavelmente um recém-nascido. Não foi possível obter mais nenhuma informação sobre o espécime. É provável que alguns fragmentos pequenos de ossos deste indivíduo tenham sido atribuídos ao Sep-IB. 


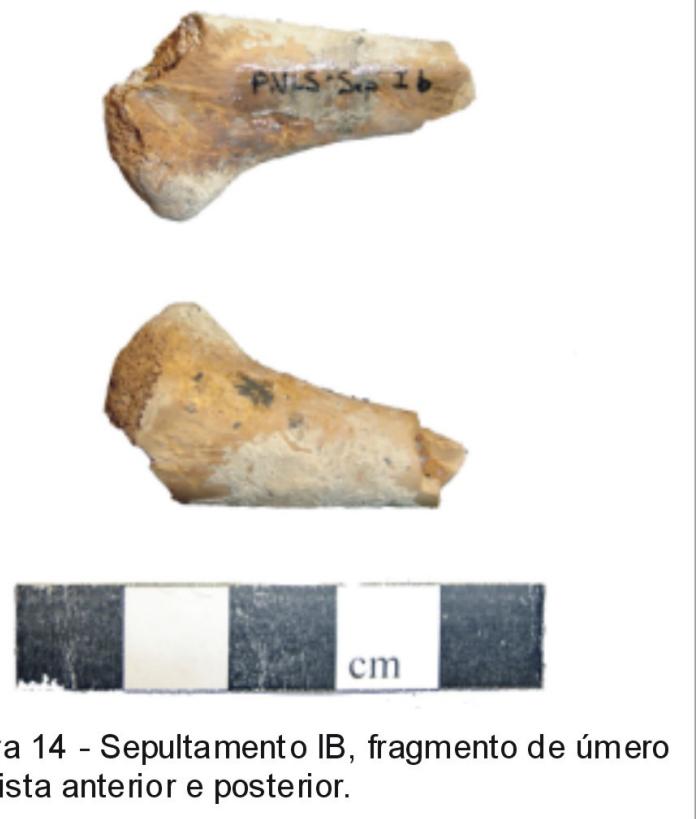

Sepultamento II

No Sep-II (Figura. 15) há um único indivíduo que está bem representado anatomicamente. Estão presentes ossos longos do braço, ante-braço e perna além de costelas, fragmentos de vértebras e ossos de mão e pé. O crânio não está bem preservado, restando apenas fragmentos centimétricos tornando impossível qualquer tentativa de análise craniométrica. Os fragmentos de crânio estavam recobertos por uma fina camada de sedimento marrom (10YR 4/4) que cobria os ossos de forma homogênea, apresentando pouca variação de tom. Não há marcas de fogo ou ocre.

A idade estimada pela observação da sínfise pubiana, segundo método proposto por Todd (1920), indica que o indivíduo morreu com cerca de 23 anos. Aplicando-se o método de estimação de idade baseado no grau de desgaste dentário (Lovejoy, 1985) estimou-se uma idade entre 20 e 24 anos para este indivíduo Em ambas as tíbias há periostites localizadas na região proximal da diáfise. Ao contrário do que ocorre com os indivíduos adultos do Sepultamento I (Sep-IA e Sep-IB), não foi observada presença de torus auditivo no meatu auditivo externo, nem osteofitose nas vértebras. Estão presentes todos os dentes com excessão dos incisivos laterais superiores, canino superior esquerdo, incisivos inferiores esquerdos e canino inferior direito (Figura. 16). 


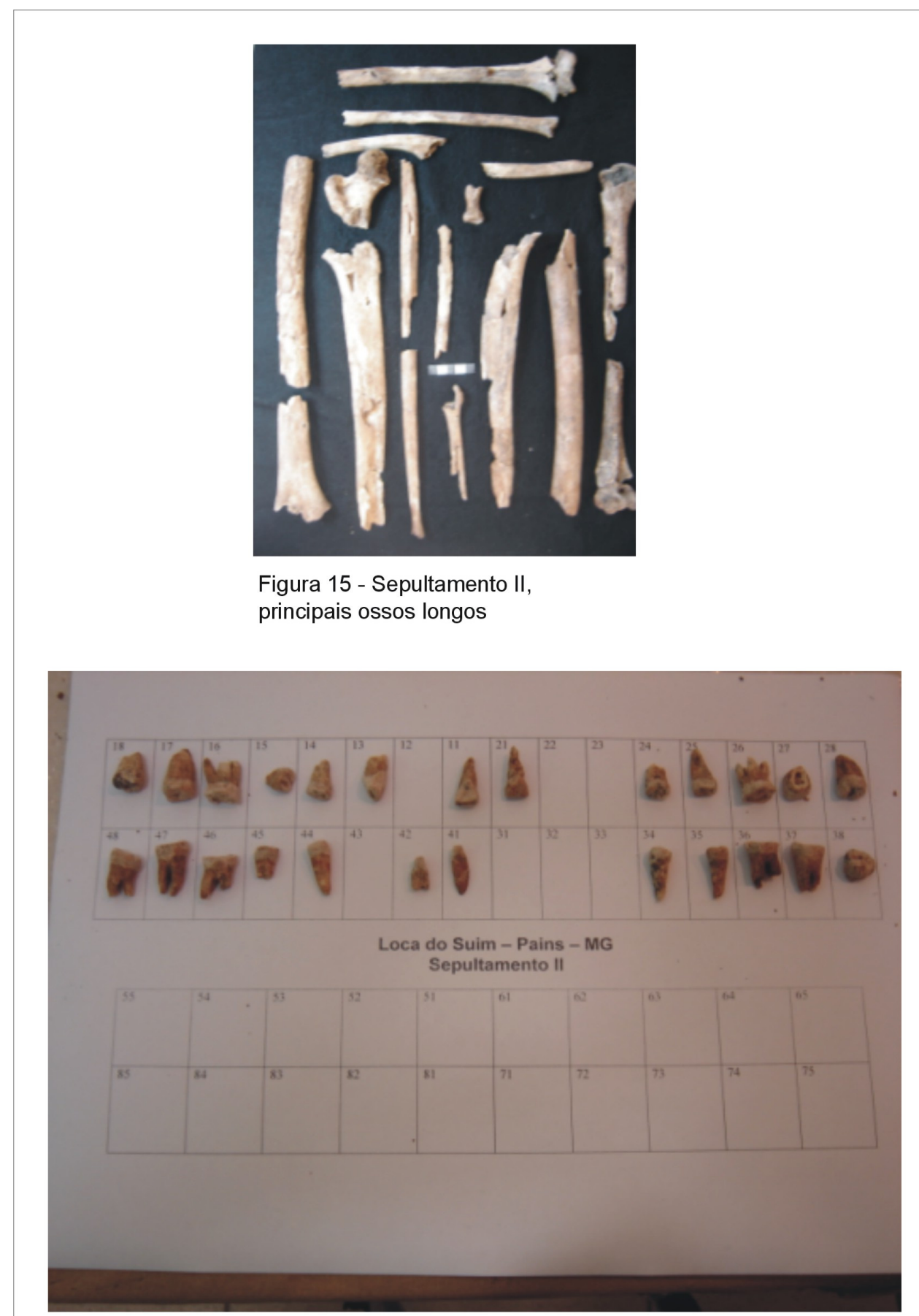

Figura 16 - Dentes do Sepultamento II 